\title{
Mycosphere notes 1-50: Grass (Poaceae) inhabiting Dothideomycetes
}

\author{
Thambugala $\mathrm{KM}^{1,2}$, Wanasinghe $\mathrm{DN}^{2,}{ }^{6,7}$, Phillips $\mathrm{AJL}^{9}$, Camporesi $\mathrm{E}^{3,4}$, Bulgakov $\mathrm{TS}^{5}$, \\ Phukhamsakda $\mathrm{C}^{2,}$ 6, 7 , Ariyawansa $\mathbf{H A}^{10}$, Goonasekara $\mathrm{ID}^{2,}$ 6, 7 , Phookamsak $\mathbf{R}^{2,}$ 6, 7, 11, \\ Dissanayake $A^{2,8}$, Tennakoon $D^{2,6,7}$, Tibpromma $S^{2,6,7}$, Chen YY, Liu $\mathrm{ZY}^{1}$ and Hyde $\mathrm{KD}^{2}$, \\ 6,7
}

${ }^{1}$ Guizhou Key Laboratory of Agricultural Biotechnology, Guizhou Academy of Agricultural Sciences, Guiyang 550006, Guizhou, People's Republic of China

${ }^{2}$ Centre of Excellence in Fungal Research, Mae Fah Luang University, Chiang Rai 57100, Thailand

${ }^{3}$ A.M.B. Gruppo Micologico Forlivese "Antonio Cicognani", Via Roma 18, Forli, Italy

${ }^{4}$ A.M.B. Circolo Micologico "Giovanni Carini”, C.P. 314 Brescia, Italy

${ }^{5}$ Russian Research Institute of Floriculture and Subtropical Crops, 2/28 Yana Fabritsiusa Street, Sochi 354002, Krasnodar region, Russia

${ }^{6}$ World Agro Forestry Centre, East and Central Asia, 132 Lanhei Road, Kunming 650201, Yunnan China

${ }^{7}$ Key Laboratory for Plant Biodiversity and Biogeography of East Asia (KLPB), Kunming Institute of Botany, Chinese Academy of Science, Kunming 650201, Yunnan China

${ }^{8}$ Institute of Plant and Environment Protection, Beijing Academy of Agriculture and Forestry Sciences, Beijing 100097, People's Republic of China

${ }^{9}$ University of Lisbon, Faculty of Sciences, Biosystems and Integrative Sciences Institute (BioISI), Campo Grande, 1749-016 Lisbon, Portugal

${ }^{10}$ Department of Plant Pathology \& Microbiology, National Taiwan University, Taipei 106, Taiwan, ROC

${ }^{11}$ Department of Biology, Faculty of Science, Chiang Mai University, Chiang Mai, 50200, Thailand

Thambugala KM, Wanasinghe DN, Phillips AJL, Camporesi E, Bulgakov TS, Phukhamsakda C, Ariyawansa HA, Goonasekara ID, Phookamsak R, Dissanayake A, Tennakoon DS, Tibpromma S, Chen YY, Liu ZY, Hyde KD 2017 - Mycosphere notes 1-50: Grass (Poaceae) inhabiting Dothideomycetes. Mycosphere 8(4), 697-796, Doi 10.5943/mycosphere/8/4/13

\begin{abstract}
This is a first of a series of papers where we bring collaborating mycologists together to produce a set of notes of 50 taxa of fungi, including the new genera Phaeopoacea, Kalmusibambusa and Neoramichloridium, 33 new species, three new combinations, two reference specimens, one epitype, an asexual report and new host records or distribution records for seven species. In this paper, we deal with 50 taxa on grasses (Poaceae or Gramineae). Grasses are ecologically dominant, monocotyledonous plants, which occur in almost every habitat worldwide. In this study, molecular sequence data and descriptions linked to morphological illustrations are used to show the diversity and taxonomy of grass-inhabiting fungal species. Sixty strains of newly collected dothideomycetous species on Poaceae in China, Italy, Russia and Thailand were identified based on morphological characters and analyses of sequence data. This research is expected to stimulate interest in grass fungi.
\end{abstract}

Keywords - Bambusicolaceae - Coniothyriaceae - Didymellaceae - Didymosphaeriaceae Massarinaceae - Mycosphaerellaceae - Periconiaceae - Phaeosphaeriaceae - Pleosporaceae Roussoellaceae - Sporormiaceae - new species 


\section{Table of Contents}

Bambusicolaceae D.Q. Dai \& K.D. Hyde

1. Bambusicola dimorpha Thambugala, Senanayake \& K.D. Hyde, sp. nov.

Coniothyriaceae W.B. Cooke

2. Coniothyrium chiangmaiense Goonas., Thambugala \& K.D. Hyde, sp. nov.

Didymellaceae Gruyter, Aveskamp \& Verkley

3. Didymella poaceicola Thambugala \& K.D. Hyde, sp. nov.

4. Epicoccum poaceicola Thambugala \& K.D. Hyde, sp. nov.

5. Epicoccum thailandicum Goonas., Thambugala \& K.D. Hyde, sp. nov.

6. Epicoccum tritici Henn.

Didymosphaeriaceae Munk

7. Kalmusibambusa Phookamsak, Tennakoon, Thambugala \& K.D. Hyde, gen. nov.

8. Kalmusibambusa triseptata Phookamsak, Tennakoon, \& K.D. Hyde, sp. nov.

9. Neokalmusia arundinis Thambugala \& K.D. Hyde, sp. nov.

10. Neokalmusia thailandica Phukhamsakda \& K.D. Hyde, sp. nov.

11. Paraphaeosphaeria graminicola Thambugala \& K.D. Hyde, sp. nov.

12. Spegazzinia neosundara Thambugala\& K.D. Hyde, sp. nov.

Massarinaceae Munk

13. Stagonospora imperaticola Phukhamsakda, Thambugala \& K.D. Hyde, sp. nov.

14. Stagonospora multiseptata Thambugala \& K.D. Hyde, sp. nov.

Mycosphaerellaceae Lindau

15. Neoramichloridium Phookamsak, Thambugala \& K.D. Hyde, gen. nov.

16. Neoramichloridium bambusicola Thambugala, Phookamsak \& K.D. Hyde, sp. nov.

Periconiaceae (Sacc.) Nann.

17. Periconia cortaderiae Thambugala \& K.D. Hyde, sp. nov.

Phaeosphaeriaceae M.E. Barr

18. Allophaeosphaeria muriformia Ariyawansa, Camporesi \& K.D. Hyde

19. Galiicola dactylidicola (Wijayaw., Camporesi \& K.D. Hyde) Thambugala, \& K.D. Hyde, comb. nov.

20. Neosetophoma poaceicola Goonas., Thambugala \& K.D. Hyde, sp. nov.

21. Neostagonospora arrhenatheri Thambugala, Camporesi \& K.D. Hyde, sp. nov.

22. Neostagonospora phragmitis Thambugala, Bulgakov \& K.D. Hyde, sp. nov.

23. Ophiosphaerella agrostidis Dern., M.P.S. Câmara, N.R. O'Neill, Berkum \& M.E. Palm

24. Parastagonospora forlicesenica Chen Y, Camporesi \& K.D. Hyde, sp. nov.

25. Parastagonospora fusiformis Thambugala, Camporesi \& K.D. Hyde, sp. nov.

26. Parastagonospora poaceicola Thambugala, Camporesi \& K.D. Hyde, sp. nov.

27. Phaeopoacea Thambugala, Dissanayake \& K.D. Hyde, gen. nov.

28. Phaeopoacea festucae Dissanayake, \& K.D. Hyde, sp. nov.

29. Phaeopoacea phragmiticola Thambugala \& K.D. Hyde, (Leuchtm) comb. nov.

30. Poaceicola dactylidis Tibpromma, Camporesi \& K.D. Hyde, sp. nov.

31. Poaceicola forlicesenica Thambugala, Camporesi \& K.D. Hyde, sp. nov.

32. Poaceicola garethjonesii Thambugala, Camporesi \& K.D. Hyde, sp. nov.

33. Poaceicola italica Thambugala, Camporesi \& K.D. Hyde, sp. nov. 
34. Septoriella chlamydospora (Jayasiri, Camporesi \& K.D. Hyde) Thambugala, \& K.D. Hyde, comb. nov.

35. Septoriella tridentinaThambugala, Camporesi \& K.D. Hyde, sp. nov.

36. Setophoma poaceicola Goonas., Thambugala \& K.D. Hyde, sp. nov.

37. Vagicola arundinis Phukhamsakda, Camporesi \& K.D. Hyde, sp. nov.

Pleosporaceae Nitschke

38. Alternaria alternata (Fr.) Keissl.

39. Alternaria dactylidicola Thambugala, Camporesi \& K.D. Hyde, sp. nov.

40. Alternaria forlicesenensis Thambugala, Camporesi \& K.D. Hyde, sp. nov.

41. Alternaria longipes (Ellis \& Everh.) E.W. Mason

42. Alternaria poaceicola Thambugala, Camporesi \& K.D. Hyde, sp. nov.

43. Comoclathris arrhenatheri Thambugala, Camporesi \& K.D. Hyde, sp. nov.

44. Comoclathris italica Tibpromma, Camporesi \& K.D. Hyde

45. Comoclathris permunda (Cooke) E. Müll.

46. Pleospora herbarum (Pers.) Rabenh.

47. Pyrenophora tritici-repentis (Died.) Drechsler

Roussoellaceae J.K. Liu, R. Phookamsak, D.Q. Dai \& K.D. Hyde

48. Roussoella doimaesalongensis Thambugala \& K.D. Hyde, sp. nov.

49. Roussoella scabrispora (Höhn.) Aptroot

\section{Sporormiaceae Munk}

50. Sparticola junci Phukhamsakda, Camporesi \& K.D. Hyde

\section{Introduction}

This is a first of a series of papers where we bring collaborating mycologists together to produce a set of notes of 50 taxa of fungi. In this paper, we report on 50 taxa from grasses. Grasses (Poaceae) are annual, biennial, or perennial flowering plants that are usually herbaceous and occur in almost every habitat worldwide, but are mostly prominent in terrestrial habitats with an estimated number of 10,000 species (Watson 1990, Kellogg 2001, Sharp \& Simon 2002). Grasses are also ecologically dominant, covering approximately $20 \%$ of the earth's land surface and include agriculturally, economically and ecologically important plants (Wheeler et al. 1982, Gibson 2009). Humans depend on grasses, including cereal crops (such as barley, maize, rice, rye sorghum and wheat) for a major portion of their diet and making alcoholic beverages, bamboo for building construction and food, sugarcane for producing sugar, rum and also an energy source (Kellogg 2001, Gibson 2009). Natural grasslands are used for grazing wild and domestic herbivores and grasses are also weeds in various ecosystems (Watson 1990, Kellogg 2001, Sharp \& Simon 2002, Dai et al. 2017).

Although grasses are economically important the study of fungi on grasses has been restricted to a few important hosts. The pathogens of grasses have been relatively well-studied (Lamprecht et al. 2011, Manamgoda et al. 2012, 2015, Damm et al. 2014, Bakhshi et al. 2015) and some books on grass diseases have been published. For example, Smiley et al. (2005) in their book of Turfgrass Diseases (Compendium of Turfgrass Diseases) have broadly discussed the damage caused by noninfectious agents in the turfgrass ecosystem and ecology and taxonomy of fungi pathogenic to turfgrasses. Phyllachora species have a broad distribution on many graminicolous hosts worldwide (Orton 1944, Parbery 1967, Pearce et al. 2000). Smut diseases are common on grasses including agriculturally important crops such as barley, wheat and rice and they reduce both yield and quality of the crops (Fischer 1937, García-Guzmán \& Burdon 1997, Brooks et al. 2009). Rust fungi (Basidiomycota, Urediniomycetes and Uredinales) comprise more than 7000 species of obligate plant pathogens that are prevalent on a number of graminicolous hosts (Cummins 1971, Aime 2006). Aegilops, Avena, Hordeum, Triticum and Secale are the common agriculturally and 
economically important grass genera on which rust diseases occur (Cummins 1971, Anikster \& Wahl 1979). Apart from that rust fungi are frequently associated with grass genera such as Arundinella, Bambusa, Bromus, Molinia, Panicum and Phragmites (Cummins 1971).

There have been many studies on fungal endophytes of grasses and their ecological importance, especially those that cause disease in grazing animals (Latchs \& Christensen 1985, Clay 1988, Purahong \& Hyde 2011). Purahong and Hyde (2011) discussed the effects of fungal endophytes on grass litter decomposition rates and many studies showed that fungal endophytes reduced decomposition rates of grass species (Omacini et al. 2004, Siegrist et al. 2010, Purahong \& Hyde 2011). On the other hand, saprobes on grasses are relatively poorly studied. However, Hyde and coworkers carried out a series of studies on fungi associated with grasses based on morphology and phylogeny (Manamgoda et al. 2012, Hyde et al. 2013, Ariyawansa et al. 2014b, Liu et al. 2014, Jayasiri et al. 2015b, Li et al. 2015, Thambugala et al. 2015a, Hyde et al. 2016, Dai et al. 2017). The fungi on Poaceae in freshwater and marine habitats have also been studied (Poon \& Hyde 1998, Wong et al. 2001, Cai et al. 2003, 2006), but much more work needs to be carried out.

Dothideomycetes occurring on grasses can be pathogens, saprobes or endophytes; the pathogens are responsible for significant annual crop losses worldwide (Wong \& Hyde 2001, Manamgoda et al. 2011, Hyde et al. 2013, 2016, Quaedvlieg et al. 2013, Thambugala et al. 2014a, 2015a, Ariyawansa et al. 2015a, Bakhshi et al. 2015, Liu et al. 2015, Wijayawardene et al. 2016, Dai et al. 2017). Most of the species of Alternaria Nees, Bipolaris Shoemaker, Parastagonospora Quaedvlieg, Pseudoseptoria Speg and Stagonospora (Sacc.) Sacc. are significant plant pathogens (Manamgoda et al. 2011, 2015, Quaedvlieg et al. 2013), while members of Bambusicola D.Q. Dai \& K.D. Hyde, Neokalmusia Kaz. Tanaka et al., Phaeosphaeria I. Miyake and Poaceicola W.J. Li et al are common saprobes usually associated with Poaceae hosts (Ariyawansa et al. 2014a, Phookamsak et al. 2014a, Li et al. 2015, Dai et al. 2017). Most of the Dothideomycetes on Poaceae need to be re-visited using a comprehensive morphology and phylogenetic study, based on DNA data. In this study, we collected Dothideomycetes on common terrestrial grasses in China, Italy, Russia and Thailand. Comprehensive descriptions with detailed illustrations of these fresh collections together with multi-gene phylogenetic analyses were used to establish their taxonomic placement within Dothideomycetes. We treat 50 taxa belong to Bambusicolaceae, Didymellaceae, Didymosphaeriaceae, Massarinaceae, Mycosphaerellaceae, Periconiaceae, Phaeosphaeriaceae, Pleosporaceae, Roussoellaceae and Sporormiaceae. Most of the fresh collections were reported on nearly 15 grass (Poaceae) genera including Anthoxanthum, Arrhenatherum, Arundo, Bambusa, Cortaderia, Dactylis, Lolium, Phleum, Phragmites, Poa, Sorghum, Triticum and Zea.

\section{Materials and methods}

\section{Sample collection, morphological study and isolation}

Fungal species associated with grasses (Poaceae / Gramineae) were collected from China (Guizhou Province), Italy (Province of Forlì-Cesena and Trento), Russia (Rostov Region) and Thailand (Provinces of Chiang Mai and Chiang Rai). Fungi from the fresh collections were isolated by a modified single spore/conidial isolation method (Manamgoda et al. 2012, Chomnunti et al. 2014). Growth rates, colony characteristics and asexual morph morphology were determined from cultures grown on $2 \%$ potato-dextrose agar (PDA), malt extract agar (MEA) or water agar (WA; 15 g/l sterile distilled water) at room temperature $\left(25^{\circ} \mathrm{C}\right)$ in the dark. Morphological observations and photomicrographs were made following the method of Thambugala et al. (2015a). Ex-type or representative isolates were deposited in Mae Fah Luang University Culture Collection (MFLUCC) with duplicates in International Collection of Microorganisms from Plants (ICMP); Guizhou Culture Collection (GZCC) or Kunming Institute of Botany Culture Collection (KUMCC), China. The collected specimens were deposited in the Herbarium of Mae Fah Luang University (MFLU), Thailand; Cryptogamic Herbarium, Kunming Institute of Botany (HKAS) or Guizhou Academy of Agricultural Sciences (GZAAS), China. Taxonomic descriptions were deposited in the Faces of 
Fungi (FOF) database as described in Jayasiri et al. (2015a) and Index Fungorum numbers were obtained as detailed in Index Fungorum (2017).

\section{DNA extraction, PCR amplification and sequencing}

Genomic DNA was extracted from fresh mycelium, following the method of Thambugala et al. (2015a) or using a DNA extraction kit (Biospin Fungus Genomic DNA Extraction Kit, BioFlux ®, China). The PCR amplifications were performed in a total volume of $25 \mu \mathrm{L}$ of PCR mixtures

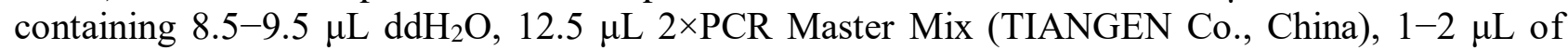
DNA template, $1 \mu \mathrm{L}$ of each primer. The translation elongation factor-1 $\alpha$ (EF1- $\alpha)$, internal transcribed spacer region (ITS), 28S nrDNA (LSU), 18S nrDNA (SSU), RNA polymerase II second largest subunit (RPB2) and $\beta$-tubulin ( $\beta$-tub) gene regions were amplified for relevant strains following the conditions mentioned in Thambugala et al. (2017). The PCR products were visualized under UV light on $1 \%$ agarose electrophoresis gels stained with ethidiumbromide. Purification and sequencing of PCR products were carried out at Invitrogen Biotechnology Co., Shanghai, China.

\section{Phylogenetic analyses}

Multi-gene phylogenetic analyses based on selected ITS, LSU, SSU, EF1- $\alpha, \beta$-tub and RPB2 sequence data were done to establish the phylogenetic placement of each isolated taxon. Single gene data sets were aligned with Bioedit 7.1.3.0 (Hall 1999) and the consensus sequences were further improved with MUSCLE implemented in MEGA 5v (Tamura et al. 2011). Alignments were checked and optimized manually when necessary.

Phylogenetic analyses were based on maximum likelihood (ML) criterion using RAxMLHPC BlackBox (8.2.4) (Stamatakis 2006, Stamatakis et al. 2008) in the CIPRES portal (Miller et al. 2010). The general time reversible model of evolution including estimation of invariable sites (GTRGAMMA + I) and assuming a discrete gamma distribution with four rate categories was used for the ML analysis. Trees were rooted with appropriate outgroups in each analysis. The best scoring trees were selected and visualized with MEGA v. 5 (Tamura et al. 2011). ML Bootstrap supports (BS) (greater than or equal to $50 \%$ ) are shown below or above each branch. All the newly generated sequences in this study were deposited in GenBank (Table 1). The resulting phylogenetic trees are presented under each relevant description.

\section{Results}

\section{Taxonomy}

In this study 50 fungal taxa were studied in 28 genera and eleven families. Species descriptions, phylogenetic results and notes are presented under the relevant family and genus.

Bambusicolaceae D.Q. Dai \& K.D. Hyde, in Hyde et al., Fungal Diversity 63: 49 (2013)

Hyde et al. (2013) introduced Bambusicolaceae to accommodate the genus Bambusicola D.Q. Dai \& K.D. Hyde and currently the family comprises three genera including Neobambusicola Crous \& M.J. Wingf. (Crous et al. 2014b) and Palmiascoma Phook. \& K.D. Hyde (Liu et al. 2015).

Bambusicola D.Q. Dai \& K.D. Hyde, Cryptog. Mycol. 33(3): 367 (2012)

The genus Bambusicola currently comprises ten species that are widely distributed on bamboo species in Asia. This genus is characterized by uni to multi-loculate ascostromata, slightly broad fusiform, 1-septate ascospores and the asexual morphs with holoblastic, annelidic conidiogenous cells and pale to dark brown, cylindrical conidia (Dai et al. 2012, Dai et al. 2017).

Bambusicola dimorpha Thambugala, Senanayake \& K.D. Hyde, sp. nov. Fig. 3 Index Fungorum number: IF552971, Facesoffungi number: FoF 03191 


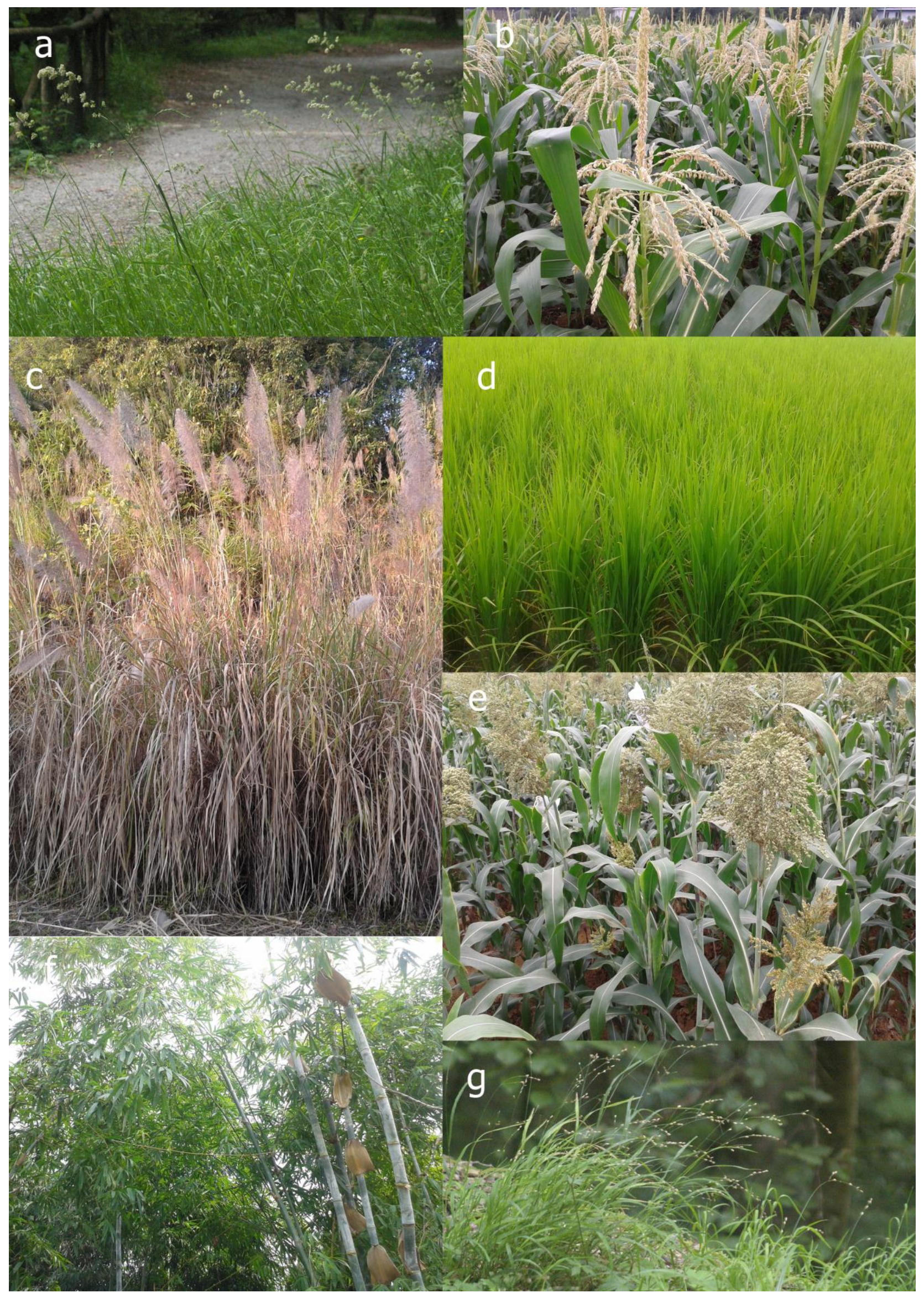

Fig. 1 - a-e. Different kinds of grasses in their natural habitats; a. Dactylis glomerata. b. Zea mays, c. Cortaderia sp. d. Oryza sativa. e. Sorghum bicolor. f. Bambusa sp. g. Melica uniflora. 
Table 1. GenBank and culture collection accession numbers of species generated in this study.

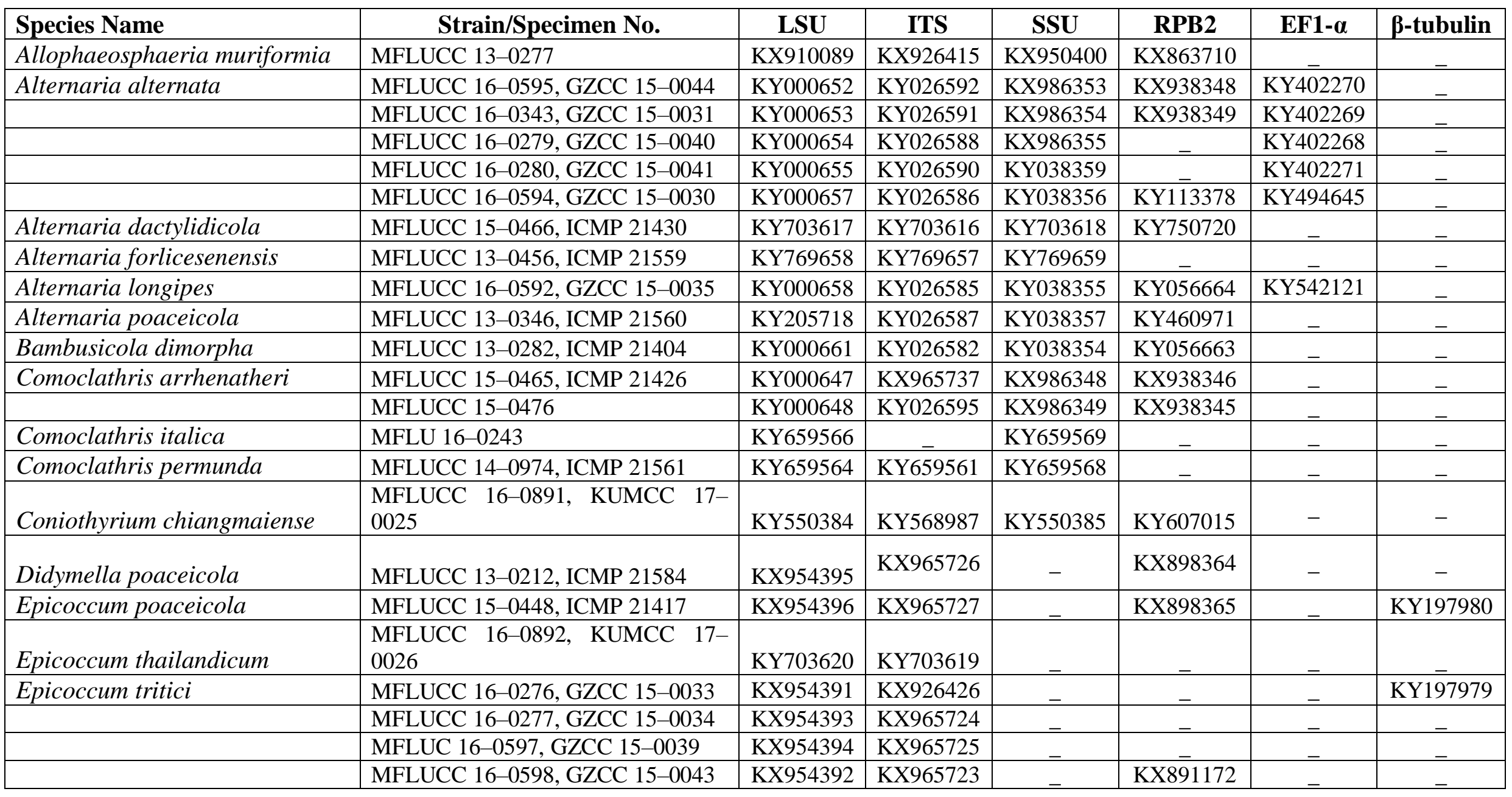


Table 1 continued. GenBank and culture collection accession numbers of species generated in this study.

\begin{tabular}{|c|c|c|c|c|c|c|c|}
\hline Species Name & Strain/Specimen No. & LSU & ITS & SSU & RPB2 & EF1- $\alpha$ & $\beta$-tubulin \\
\hline Kalmusibambusa triseptata & MFLUCC 13-0232, KUMCC 16-0183 & KY682695 & KY682697 & KY682696 & & & \\
\hline \multirow{2}{*}{ Neokalmusia arundinis } & MFLUCC 15-0463, ICMP 21431 & KX954399 & KX965730 & KX986343 & & KY244024 & \\
\hline & MFLUCC $14-0222$ & KX954400 & KX965731 & KX986344 & & KY271091 & \\
\hline \multirow[t]{2}{*}{ Neokalmusia thailandica } & MFLUCC 16-0405, ICMP 21564 & KY706132 & KY706142 & KY706142 & KY706148 & KY706145 & \\
\hline & MFLUCC 16-0399 & KY706131 & KY706141 & KY706136 & & & \\
\hline Neoramichloridium bambusicola & MFLUCC 15-0455, ICMP 21407 & KY205720 & KY205719 & & & & \\
\hline Neosetophoma poaceicola & MFLUCC 16-0886, KUMCC 17-0023 & KY550382 & KY568986 & KY550383 & & - & \\
\hline Neostagonospora arrhenatheri & MFLUCC 15-0464, ICMP 21422 & KX910091 & KX926417 & KX950402 & & 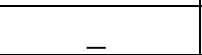 & \\
\hline Neostagonospora phragmitis & MFLUCC 16-0493, ICMP 21424 & KX910090 & KX926416 & KX950401 & KX880498 & _- & \\
\hline Paraphaeosphaeria graminicola & MFLUCC 15-0450, ICMP 21421 & KX954398 & KX965729 & KX986342 & & & KY197981 \\
\hline Parastagonospora forlicesenica & MFLUCC 13-0557, MFLUCC 15-0461 & KY769661 & KY769660 & KY769662 & & _- & - \\
\hline Parastagonospora fusiformis & MFLUCC 13-0215 & KX910088 & KX926418 & KX950403 & KX863711 & & \\
\hline Parastagonospora poaceicola & MFLUCC 15-0471, ICMP 21415 & KX910092 & KX926419 & KX950404 & KX880499 & & - \\
\hline \multirow[t]{3}{*}{ Periconia cortaderiae } & MFLUCC 15-0457, ICMP 21414 & KX954401 & KX965732 & KX986345 & 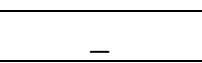 & KY310703 & \\
\hline & MFLUCC $15-0451$ & KX954403 & KX965734 & KX986346 & & KY429208 & \\
\hline & MFLUCC 15-0453, ICMP 21429 & KX954402 & KX965733 & & & KY320574 & \\
\hline Phaeopoacea festucae & MFLUCC 17-0056 & KY824767 & KY824766 & KY824769 & KY824768 & 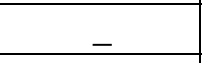 & \\
\hline Pleospora herbarum & MFLUCC 14-0920 & KY659563 & KY659560 & KY659567 & & & \\
\hline Poaceicola dactylidis & MFLUCC 14-0002 & KY657264 & & KY657265 & & - & \\
\hline Poaceicola forlicesenica & MFLUCC 15-0470, ICMP 21411 & KX910095 & KX926422 & KX950406 & KY131966 & & \\
\hline \multirow[t]{2}{*}{ Poaceicola garethjonesii } & MFLUCC 15-0469, ICMP 21408 & KX954390 & KX926425 & KY205717 & KX898363 & & \\
\hline & MFLUCC 13-0275 & KX910093 & KX926420 & KX950405 & KX880500 & & \\
\hline Poaceicola italica & MFLUCC 13-0267, ICMP 21567 & KX910094 & KX926421 & KX950409 & KX891169 & & \\
\hline
\end{tabular}


Table 1. continued. GenBank and culture collection accession numbers of species generated in this study.

\begin{tabular}{|c|c|c|c|c|c|c|c|}
\hline Species Name & Strain/Specimen No. & LSU & ITS & SSU & RPB2 & EF1- $\alpha$ & $\beta$-tubulin \\
\hline \multirow[t]{2}{*}{ Pyrenophora tritici-repentis } & MFLUCC 16-0494, ICMP 21428 & KY000649 & KY026596 & KX986350 & KY073135 & - & - \\
\hline & MFLUCC $16-0492$ & KY000651 & KY026593 & KX986352 & KY073136 & & \\
\hline Septoriella tridentina & MFLUCC $15-0475$ & KX910097 & KX926424 & KX950408 & KX891171 & & \\
\hline Setophoma poaceicola & MFLUCC 16-0880 & KY550386 & KY568988 & KY550387 & KY609967 & & \\
\hline Sparticola junci & MFLU $16-0242$ & KY659565 & KY659562 & - & - & - & - \\
\hline Stagonospora multiseptata & MFLUCC 15-0449, ICMP 21562 & KX954404 & KX965735 & - & - & - & KY197982 \\
\hline Roussoella doimaesalongensis & MFLUCC 14-0584, ICMP 21416 & KY000659 & KY026584 & - & KY678394 & KY651249 & \\
\hline Roussoella scabrispora & MFLUCC 14-0582, ICMP 21406 & KY000660 & KY026583 & & & & \\
\hline \multirow[t]{2}{*}{ Vagicola arundinis } & MFLUCC $15-0027$ & KY706129 & KY706139 & KY706134 & & & \\
\hline & MFLUCC 15-0046 & KY706130 & KY706140 & KY706135 & KY706147 & KY706144 & \\
\hline
\end{tabular}

Etymology - Referring to the two types of conidia in the asexual morph.

Holotype - MFLU 16-2598

Saprobic on dead culm of bamboo. Sexual morph: Ascostromata up to 1-2 mm diameter, solitary to gregarious, immersed in the host tissue, becoming erumpent, multi-loculate, black, coriaceous. Locules 300-500 $\mu \mathrm{m}$ diameter $\times 300-520 \mu \mathrm{m}$ high $(\bar{x}=406 \times 360 \mu \mathrm{m}$, $\mathrm{n}=6)$, completely immersed in ascostromata, globose to subglobose, ostiolate. Peridium up to $60 \mu \mathrm{m}$ wide, comprising several layers of dark brown to lightly pigmented, thick-walled cells of textura angularis to textura prismatica, intermingled with host cells. Hamathecium composed of $1-1.5 \mu \mathrm{m}$ wide, dense, aseptate, unbranched, anastomosing, trabeculate pseudoparaphyses, situated between and above the asci. Asci 70-90 $\times 9.5-11(-12) \mu \mathrm{m}(\bar{x}=80 \times 10.4 \mu \mathrm{m}, \mathrm{n}=$ 20), 8-spored, bitunicate, fissitunicate, cylindrical, short-pedicellate, straight or slightly curved, apically rounded with an ocular chamber. Ascospores $(17.5-) 20-23(-25) \times 3.4-5.6 \mu \mathrm{m}(\bar{x}=21.2 \times 4.5 \mu \mathrm{m}, \mathrm{n}=30)$, overlapping 1-2-seriate, hyaline, fusiform, 1-septate, 2-euseptate, occasionally with large upper cell, with narrowly rounded ends, surrounded by a thin mucilaginous sheath, guttulate, smooth-walled. Asexual morph: Coelomycetous, 
produced on bamboo pieces on PDA after 1 month. Conidiomata (140-)210-340 $\mu \mathrm{m}$ diameter $\times$ $(100-) 200-250 \mu \mathrm{m}$ high $(\bar{x}=230 \times 200 \mu \mathrm{m}, \mathrm{n}=5)$, pycnidial, solitary to gregarious, superficial, uni- to multi-loculate, with indistinct ostioles. Conidiomatal wall 17-30(-50) $\mu \mathrm{m}$ wide, composed of several layers, of thin- to thick-walled, dark brown to black cells of textura angularis to textura prismatica. Conidiophores reduced to conidiogenous cells. Conidiogenous cells $6.5-10(-12) \times 1.4-$ $2.4 \mu \mathrm{m}(\bar{x}=8.6 \times 1.8 \mu \mathrm{m}, \mathrm{n}=30)$, holoblastic, cylindrical to subcylindrical, hyaline, smooth. Conidia two types, macro and micro conidia. Macro-conidia 13-21 $\times(2.5-) 3-4.2 \mu \mathrm{m}(\bar{x}=17 \times$ $3.4 \mu \mathrm{m}, \mathrm{n}=40$ ), cylindrical to ellipsoidal, with narrow to broadly rounded ends, 1 -septate, pale brown to brown, slightly constricted at the septum, smooth, with small to large guttules. Microconidia 2.4-4.8 $\times 1.6-2.4 \mu \mathrm{m}(\bar{x}=3.1 \times 1.9 \mu \mathrm{m}, \mathrm{n}=50)$, oblong to ellipsoidal, with rounded to obtuse ends, initially hyaline, becoming brown, aseptate, guttulate, smooth-walled, without a mucilaginous sheath.

Culture characteristics - Ascospores germinating on PDA within $24 \mathrm{~h}$ and germ tubes produced from both ends. Colonies growing on PDA, reaching a diam. of $12-15 \mathrm{~mm}$ after $10 \mathrm{~d}$ at $25{ }^{\circ} \mathrm{C}$, flat to slightly umbonate, surface smooth to velvety, with entire to slightly undulate edge, greenish olivaceous to white, moderately dense, circular; reverse greenish to black.

Notes - Bambusicola dimorpha and B. pustulata are the morphologically and phylogenetically closest species in the genus, but $B$. dimorpha differs from $B$. pustulata in having multi-loculate ascostromata, larger ascospores with a sheath and two different types of conidia. Bambusicola dimorpha also received high bootstrap support value $(97 \%)$ in the phylogenetic analysis (Fig. 2).

Material examined - THAILAND, Chiang Mai Province, Doi Inthanon, on dead bamboo culms, 2 November 2012, Indunil C. Senanayake, TL 022 (MFLU 16-2598, holotype); ibid., (GZAAS 16-0128, isotype), ex-type living culture MFLUCC 13-0282, ICMP 21404

Coniothyriaceae W.B. Cooke, Revta Biol., Lisb. 12: 289 (1983)

The family Coniothyriaceae was introduced by Cooke (1983b) and it has been considered as a synonym of Leptosphaeriaceae (Kirk et al. 2008, de Gruyter et al. 2009). However, currently Coniothyriaceae is accepted as a distinct family in Pleosporales (Hyde et al. 2013, Quaedvlieg et al. 2013, Wijayawardene et al. 2016).

Coniothyrium Corda, Icon. Fung. (Prague) 4: 38.1840

Coniothyrium and coniothyrium-like species are considered to be polyphyletic with species occurring in several clades of the order Pleosporales (Hyde at al. 2013, Verkley et al. 2014, Chen et al. 2015). However, Coniothyrium sensu stricto groups within Coniothyriaceae, Pleosporales (Verkley et al. 2014, Chen et al. 2015, Wijayawardene et al. 2016).

Coniothyrium chiangmaiense Goonas., Thambugala \& K.D. Hyde, sp. nov.

Fig. 5

Index Fungorum number: IF552972, Facesoffungi number: FoF 03192

Etymology - Referring to the province Chiang Mai, where the species was first encountered.

Holotype - MFLU 16-2854

Saprobic on dead stem of grass litter, forming black, elongated, raised structures, ascostromata opening through slits along the length. Sexual morph: Ascostromata $0.13-0.25 \mathrm{~mm}$ long, 0.1-0.18 mm wide, 0.1-0.2 $\mathrm{mm}$ high, solitary, immersed, fusiform. Ascomata perithecial, 120-270 $\mu \mathrm{m}$ high, 200-380 $\mu \mathrm{m}$ diameter, 3-4 perithecia immersed within the ascostromata, subglobose or globose with a flattened base, dark brown, with centrally located short ostiole. Peridium 6.8-9 $\mu \mathrm{m}$ wide, thick to thin-walled, of unequal thickness, poorly developed at the base and merging with host tissue, composed of several layers of outer brown to inner hyaline, pseudoparenchymatous cells of textura prismatica. Hamathecium of dense, 1-2.2 $\mu \mathrm{m}$ wide, filamentous, indistinct, septate, cellular pseudoparaphyses, not constricted at the septum. Asci 60$75 \times 5.5-8 \mu \mathrm{m}(\bar{x}=67 \times 7 \mu \mathrm{m}, \mathrm{n}=15), 8$-spored, bitunicate, fissitunicate, cylindric-clavate, with broad flat pedicel, apex rounded. Ascospores $13-17 \times 3.5-5 \mu \mathrm{m}(\bar{x}=15 \times 4.2 \mu \mathrm{m}, \mathrm{n}=20)$, 
overlapping uni-seriate, hyaline, fusiform, with rounded to acute ends, 1-septate, slightly constricted at the septum, cells broader near the septum, smooth-walled, guttulate. Asexual morph: Undetermined.

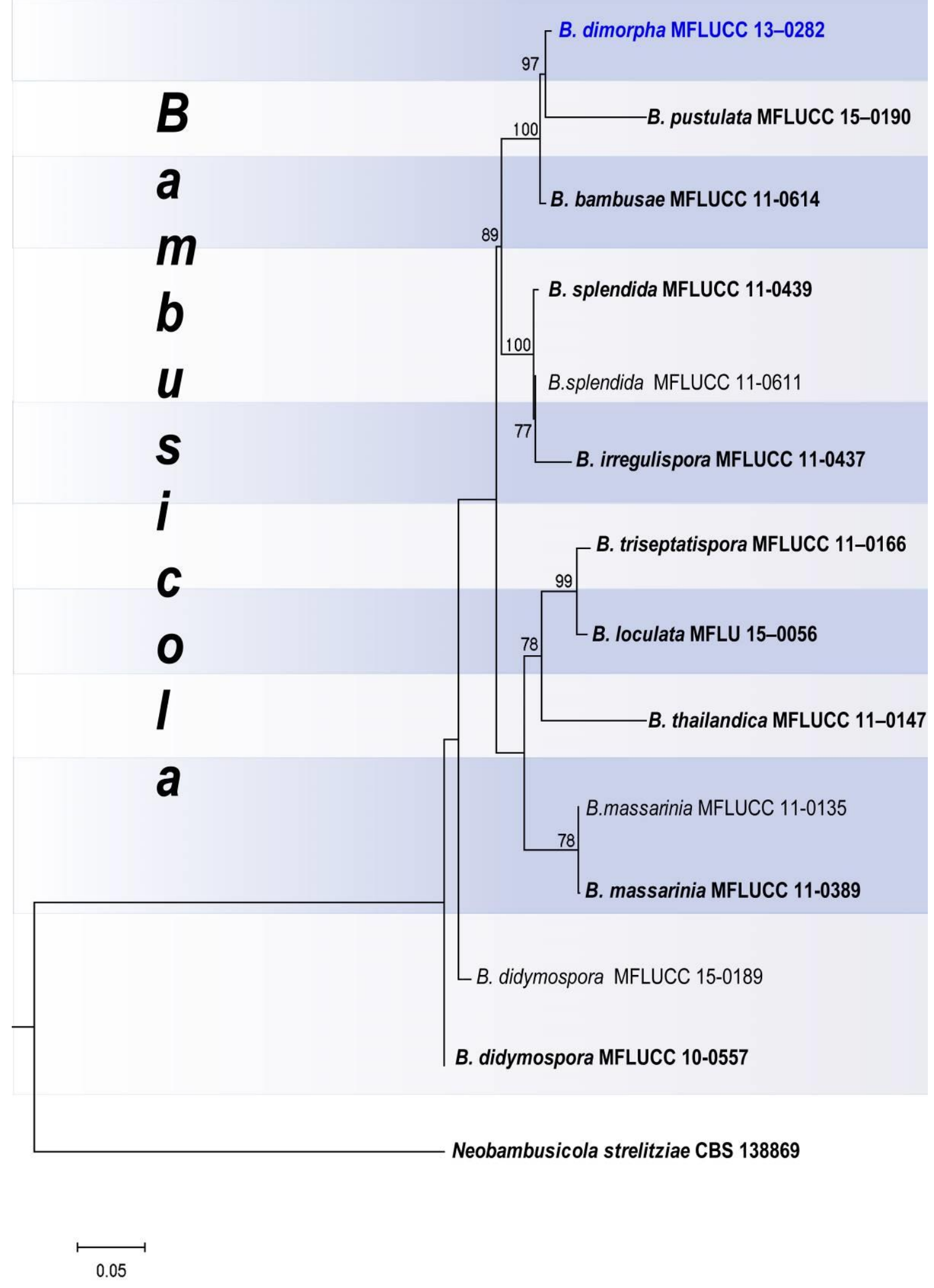

Fig. 2 - Phylogram resulting from maximum likelihood (RAxML) analysis of a combined LSU, ITS and RPB2 dataset of Bambusicola, Bambusicolaceae. Bootstrap support values equal or greater than $50 \%$ are given above or below the nodes. The ex-type strains are in bold and the new isolate in blue. The tree is rooted to Neobambusicola strelitziae. 
Culture characteristics - Conidia germinating on PDA within $12 \mathrm{~h}$ reaching a diameter of 25 $\mathrm{mm}$ after $7 \mathrm{~d}$ at $25^{\circ} \mathrm{C}$, irregular, dense, floccose and velvety, slightly raised with fimbriate margin, greenish-grey; reverse dark grey.

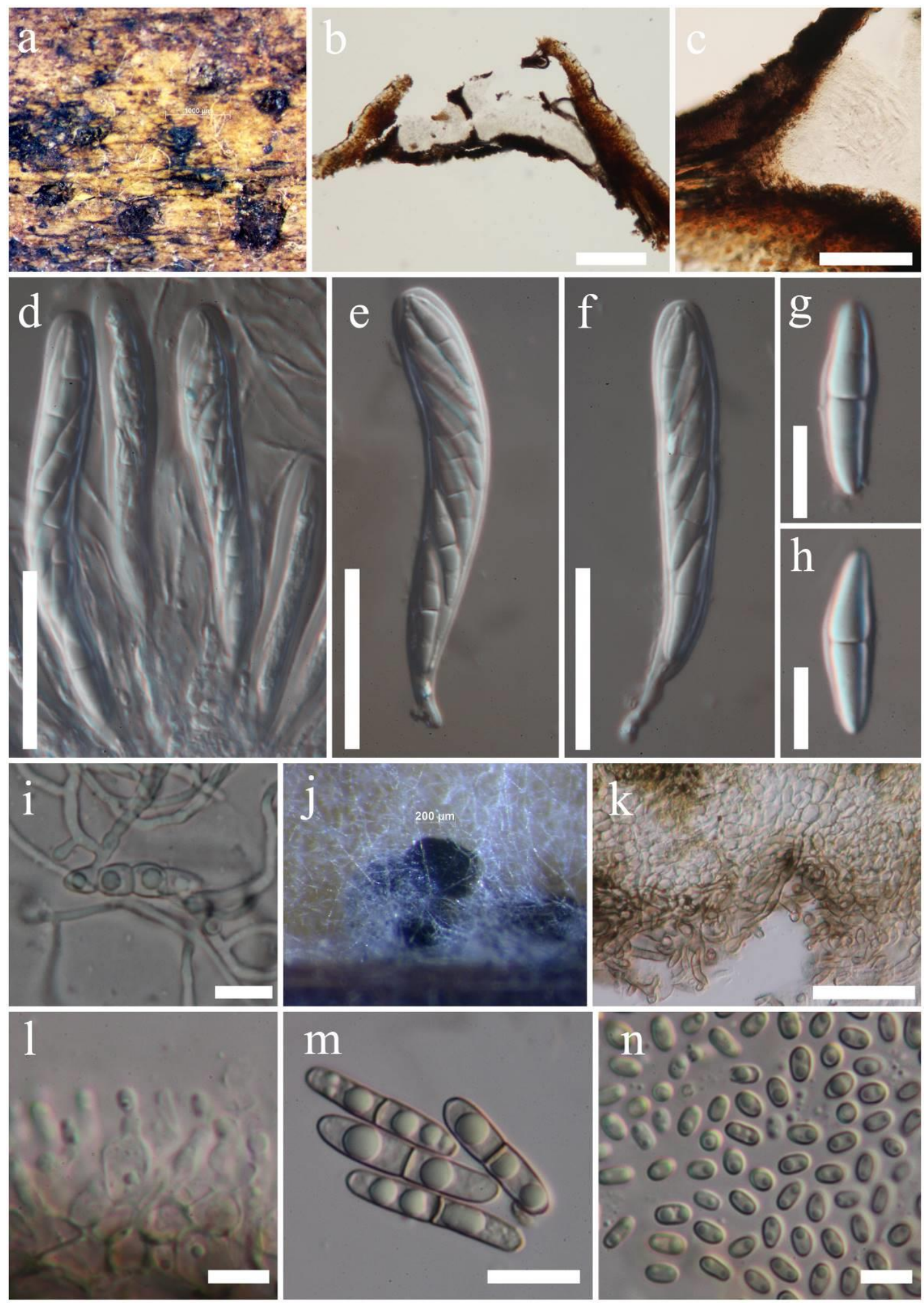

Fig. 3 - Bambusicola dimorpha (MFLU 16-2598, holotype). a. Appearance of ascostromata on a bamboo culm. b. Vertical section through ascostroma. c. Peridium. d-f. Asci. g, h. Ascospores. i. Germinating ascospore. j. Conidiomata formed on a toothpick. k. Conidiomatal wall. 1. Conidiogenous cells. $\mathrm{m}, \mathrm{n}$. Conidia. Scale bars: $\mathrm{b}=250 \mu \mathrm{m} ; \mathrm{c}=100 \mu \mathrm{m}, \mathrm{d}-\mathrm{f}, \mathrm{k}=30 \mu \mathrm{m}, \mathrm{g}-\mathrm{i}, \mathrm{m}=$ $10 \mu \mathrm{m}, 1=5 \mu \mathrm{m}$. 


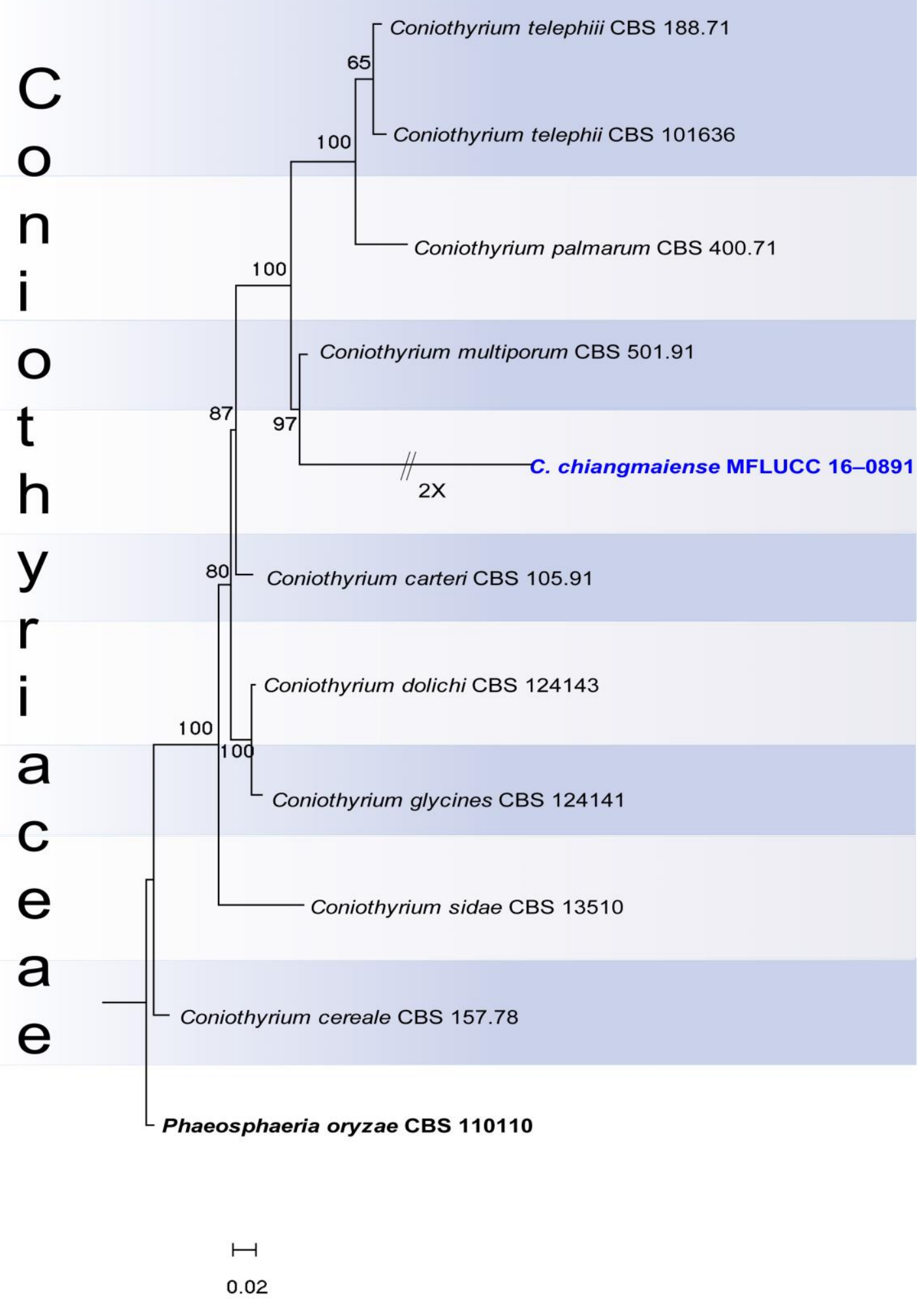

Fig. 4 - Phylogram resulting from maximum likelihood (RAxML) analysis of a combined LSU, SSU, ITS and RPB2 dataset of Coniothyrium, Coniothyriaceae. Bootstrap support values equal or greater than $50 \%$ are given above or below the nodes. The ex-type strains are in bold and the new isolate in blue. The tree is rooted to Phaeosphaeria oryzae.

Material examined - THAILAND, Chiang Mai Province, Mae Taeng, Mushroom Research Center, on grass litter, 24 March 2016, Ishani D. Goonasekara IGm 28 (MFLU 16-2854, 
holotype); ibid. (HKAS 97390, isotype), ex-type living culture MFLUCC 16-0891, KUMCC 170025.

Notes - A sexual morph of Coniothyrium was collected in this study and phylogenetic analysis confirmed its placement in Coniothyriaceae (Fig. 4). The sexual morphs of Coniothyrium are rarely reported, however a paraphaeosphaeria-like sexual morph was recorded in the genus Coniothyrium by Quaedvlieg et al. (2013).
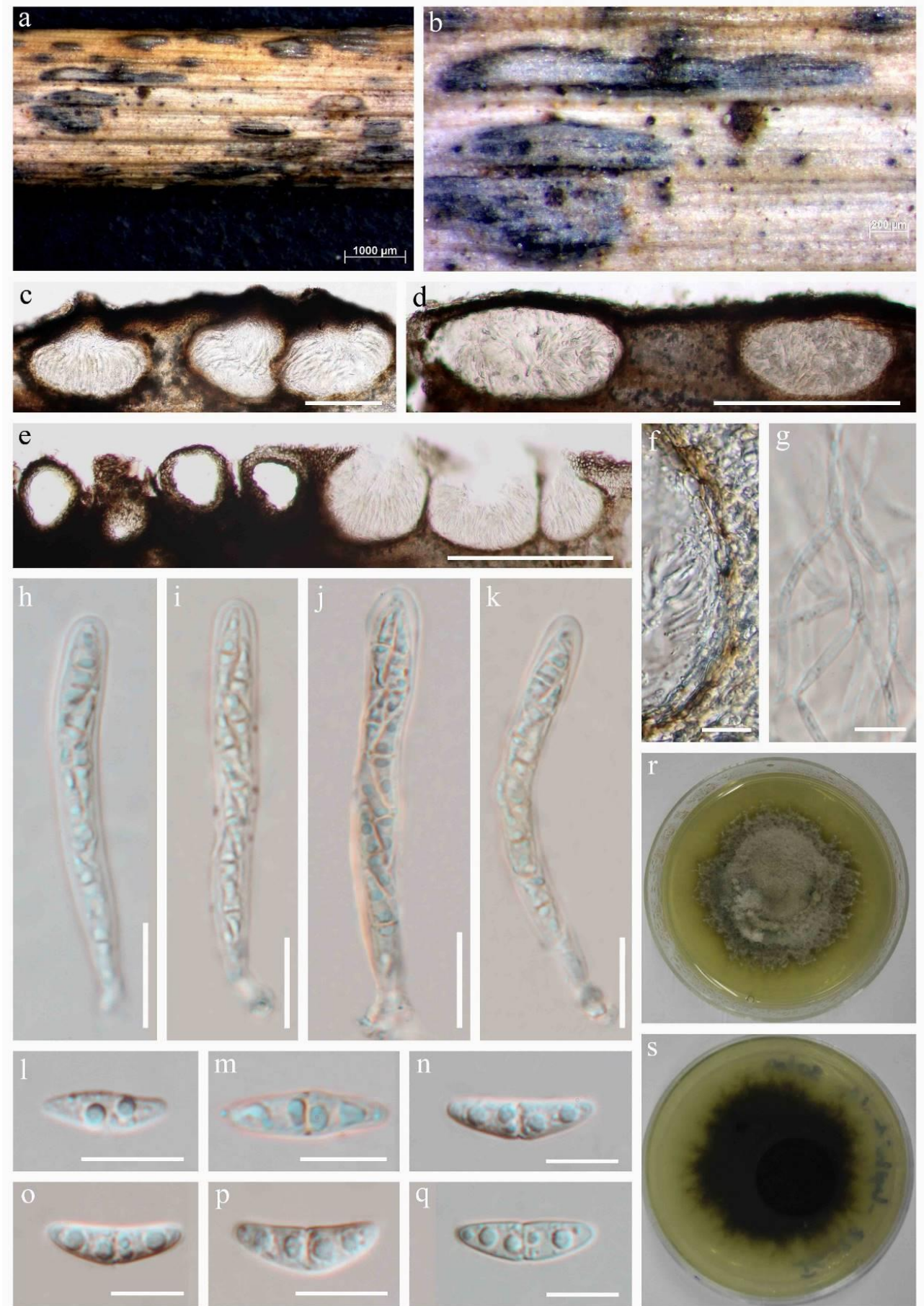

Fig. 5 - Coniothyrium chiangmaiense (MFLU 16-2854, holotype). a. Appearance of ascostromata on host surface. b. Close up of ascostromata c-e. Vertical sections through ascostromata. f. Peridium of locule. g. Pseudoparaphyses. h-k. Asci. l-q. Ascospores. r, s. Culture characteristics (from above and reverse). Scale bars: $\mathrm{c}-\mathrm{e}=250 \mu \mathrm{m}, \mathrm{f}=20 \mu \mathrm{m}, \mathrm{g}, \mathrm{l}-\mathrm{q}=10 \mu \mathrm{m}, \mathrm{h}-\mathrm{k}=15 \mu \mathrm{m}$.

Didymellaceae Gruyter, Aveskamp \& Verkley, Mycol. Res. 113(4): 516 (2009) 
This family includes plant pathogenic, saprobic and endophytic species associated with a wide range of hosts and substrates worldwide (Hyde et al. 2013, Chen et al. 2015, Liu et al. 2015, Thambugala et al. 2017). Chen et al. (2015) revised the family based on multi-gene (ITS, LSU, RPB2 and tub2) phylogenetic analysis and morphological observations and introduced new nine genera.

Didymella Sacc., Michelia 2(no. 6): 57 (1880)

Didymella was introduced by Saccardo (1880) with Didymella exigua (Niessl) Sacc. as the type species of the genus. Recently Chen et al. (2015) emended Didymella to accommodate Peyronellaea and several other phoma-like species that grouped together with type species of Didymella.

Didymella poaceicola Thambugala \& K.D. Hyde, sp. nov.

Fig. 7

Index Fungorum number: IF552994, Facesoffungi number: FoF 03213

Etymology - in reference to the holotype occurring on grasses (Poaceae)

Holotype - MFLU 16-2574

Saprobic on grasses. Sexual morph: Undetermined. Asexual morph: Conidiomata 125-270 $\times 120-260 \mu \mathrm{m}(\bar{x}=200 \times 205 \mu \mathrm{m}, \mathrm{n}=10)$, pycnidial, solitary, gregarious, or in groups, scattered, semi-immersed to erumpent, unilocular, globose to subglobose, ostiolate. Conidiomatal wall 15-25 $\mu \mathrm{m}$ wide, comprising several layers of lightly pigmented to dark brown, thick-walled, cells of textura angularis. Conidiophores reduced to conidiogenous cells. Conidiogenous cells $6-9 \times 5.5-$ $10 \mu \mathrm{m}(\bar{x}=7.7 \times 8.5 \mu \mathrm{m}, \mathrm{n}=20)$, holoblastic, hyaline, smooth, ampulliform to doliiform, lining the conidiomatal cavity. Conidia $4-9.5 \times 2.4-4.5 \mu \mathrm{m}(\bar{x}=6 \times 3 \mu \mathrm{m}, \mathrm{n}=40)$, ellipsoidal to cylindrical, initially hyaline, becoming pale brown, 0-1-septate, thin-walled, smooth, sometimes with small guttules.

Culture characteristics - Conidia germinating on PDA within $18 \mathrm{~h}$ and germ tubes produced from one or both ends. Colonies growing on PDA, reaching a diameter of $30 \mathrm{~mm}$ after $7 \mathrm{~d}$ at $25^{\circ} \mathrm{C}$, flat, surface smooth, with entire edge, white to pale brown olivaceous, moderately dense, circular; white to pale brown olivaceous.

Material examined - THAILAND, Chiang Rai, Mae Fah Luang University, on dead leaves of Poaceae sp., 21 December 2012, K.M. Thambugala KM 685 (MFLU 16-2574, holotype); ibid. (GZAAS 16-0119, isotype), ex-type living culture MFLUCC 13-0212, ICMP 21584

Notes - Didymella poaceicola is described here as a new species mainly based on phylogeny. Didymella poaceicola separates from other Didymella species forming a robust clade with $88 \% \mathrm{ML}$ bootstrap support (Fig. 6).

Epicoccum Link, Mag. Gesell. naturf. Freunde, Berlin 7: 32 (1816) [1815]

The genus Epicoccum is known as a hyphomycetous asexual morph in the family Didymellaceae (Hyde et al. 2013). However, Chen et al. (2015) emended the genus with coelomycetous synasexual morphs and five Phoma species were recombined into the genus Epicoccum based on multi-gene phylogenetic analysis.

Epicoccum poaceicola Thambugala \& K.D. Hyde, sp. nov.

Fig. 9

Index Fungorum number: IF552995, Facesoffungi number: FoF 03214

Etymology - in reference to the holotype occurring on grasses (Poaceae)

Holotype - MFLU 16-2573

Saprobic on grasses. Sexual morph: Undetermined. Asexual morph: Conidiomata 75-270 $(330) \times 85-200(-350) \mu \mathrm{m}(\bar{x}=148 \times 156 \mu \mathrm{m}, \mathrm{n}=15)$, pycnidial, solitary or gregarious, scattered, semi-immersed to erumpent, or superficial uniloculate to multi-loculate, globose to subglobose, ostiolate. Conidiomatal wall 15-35 $\mu \mathrm{m}$ wide, comprising several layers of dark brown to lightly pigmented, cells of textura angularis, with outer layers composed of thick-walled, dark brown, somewhat flattened cells, becoming lighter towards the inner layers of hyaline cells. Conidiophores 


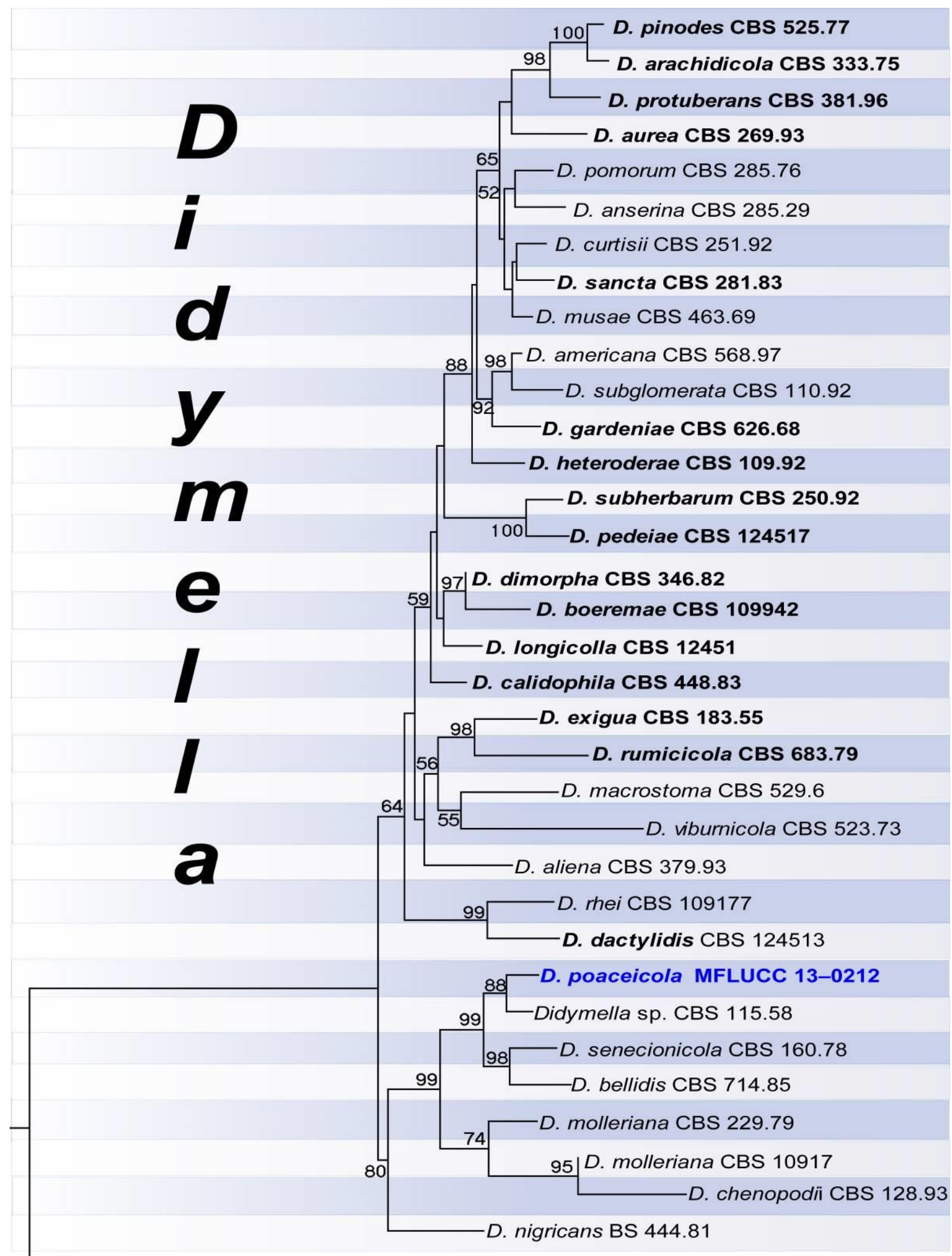

Epicoccum nigrum CBS 173.73

Fig. 6 - Phylogram resulting from maximum likelihood (RAxML) analysis of the combined LSU, ITS, RPB2 and $\beta$-tubulin sequences of 34 strains representing the genus Didymella. Maximum likelihood bootstrap support values equal to or greater than $50 \%$ are indicated above or below the nodes. The ex-type strains are in bold and the new isolates are in blue. The tree is rooted to Epicoccum nigrum (CBS 173.73). 

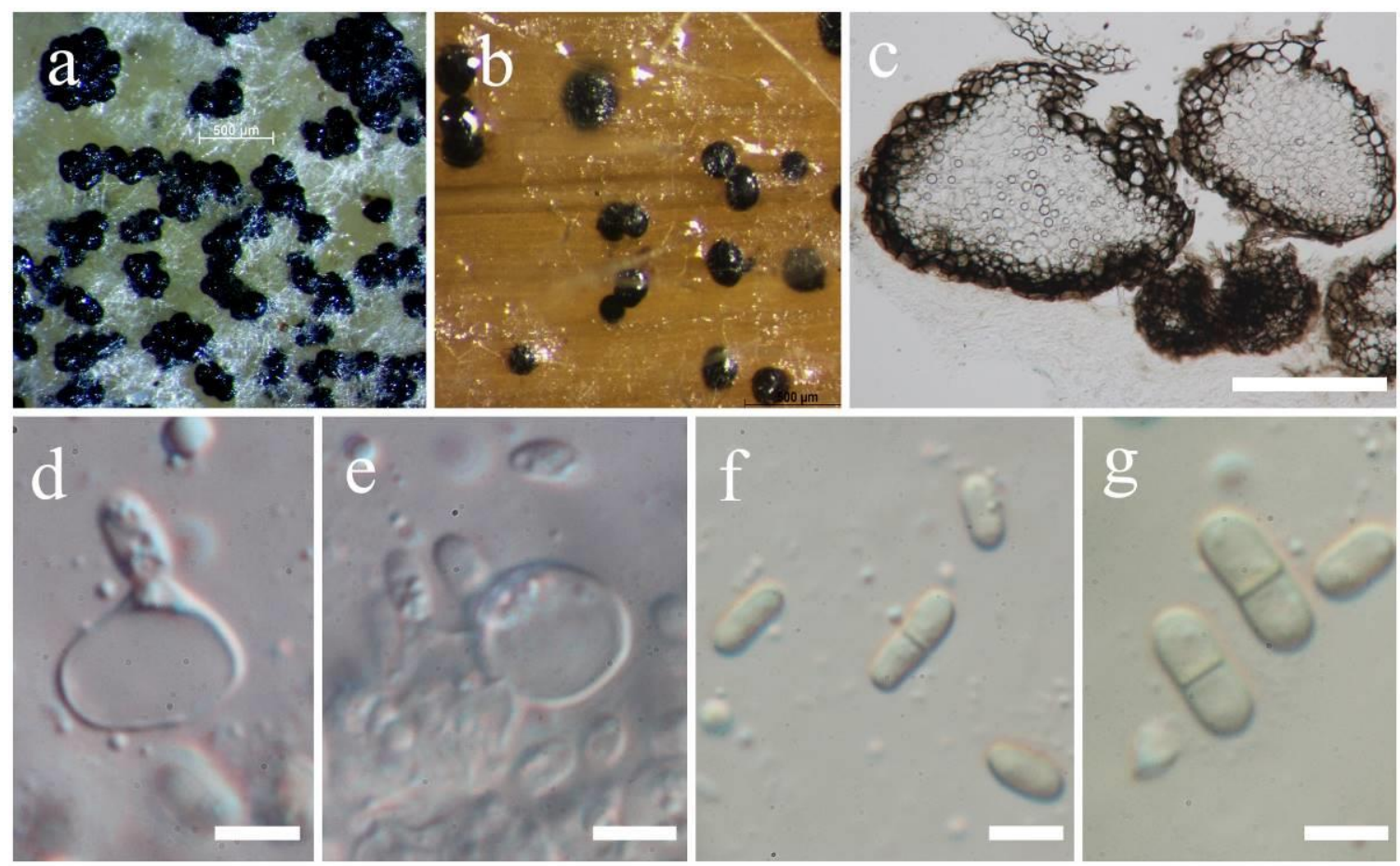

Fig. 7 - Didymella poaceicola (MFLU 16-2574, holotype). Appearance of conidiomata sporulating a. on PDA. b. on Poaceae host. c. Vertical sections through conidiomata. d, e. Conidiogenous cells and developing conidia. $\mathrm{f}, \mathrm{g}$. Conidia. Scale bars: $\mathrm{c}=100 \mu \mathrm{m}, \mathrm{d}-\mathrm{g}=5 \mu \mathrm{m}$.

reduced to conidiogenous cells. Conidiogenous cells 3.5-6.5(-10) $\times 4.5-10 \mu \mathrm{m}(\bar{x}=5.4 \times 6.7 \mu \mathrm{m}$, $\mathrm{n}=15$ ), holoblastic to phialidic, hyaline, smooth, ampulliform to doliiform, lining the conidiomatal cavity. Conidia (2-)3-5.7 $\times 1.8-3 \mu \mathrm{m}(\bar{x}=4 \times 2.2 \mu \mathrm{m}, \mathrm{n}=70)$, ellipsoidal to cylindrical, hyaline, aseptate, smooth-walled, sometimes with small guttules.

Culture characteristics - Conidia germinating on PDA within $18 \mathrm{~h}$. Colonies growing on PDA, reaching a diameter of $38 \mathrm{~mm}$ after $3 \mathrm{~d}$ at $25^{\circ} \mathrm{C}$, flat to umbonate, surface smooth to velvety, with entire edge, white to pale pink, dense, circular; reverse reddish to pinkish, with a pale-reddish pigmentation.

Material examined - THAILAND, Chiang Rai Province, Doi Mae Salong, on dead leaves of Poaceae sp., 17 July 2014, K.M. Thambugala KM 13-2 (MFLU 16-2573, holotype); ibid. (GZAAS 16-0118, isotype), ex-type living culture MFLUCC 15-0448, ICMP 21417

Notes - Epicoccum poaceicola is described here as another new phoma-like species based on our phylogenetic analysis. Epicoccum sorghinum (Sacc.) Aveskamp et al. is the phylogenetically closest species to E. poaceicola (Fig. 8), separated into distinct sub-clades with $70 \%$ ML bootstrap support. This is the first report of phoma-like Epicoccum species in Thailand.

Epicoccum thailandicum Goonas., Thambugala \& K.D. Hyde, sp. nov.

Fig. 10

Index Fungorum number: IF552996, Facesoffungi number: FoF 03215

Etymology - The specific epithet "thailandicum" refers to the country where the taxon was first collected.

Holotype - MFLU 16-2855

Saprobic on grass litter. Sexual morph: Undetermined. Asexual morph: Conidiomata 100 $150 \mu \mathrm{m}$ diameter, 50-70 $\mu \mathrm{m}$ high $(\bar{x}=127 \times 60 \mu \mathrm{m}, \mathrm{n}=10)$, pycnidial, solitary, in linear rows, immersed, visible as black elongated patches on host surface, subglobose with a flattened base. Conidiomata wall 8.5-16 $\mu \mathrm{m}$ wide, comprising outer thick-walled, dark brown to light brown cells of textura angularis to textura prismatica and inner hyaline cells of textura angularis, with outer cells at base gradually fusing with host tissues and indistinguishable. Conidiophores reduced to 


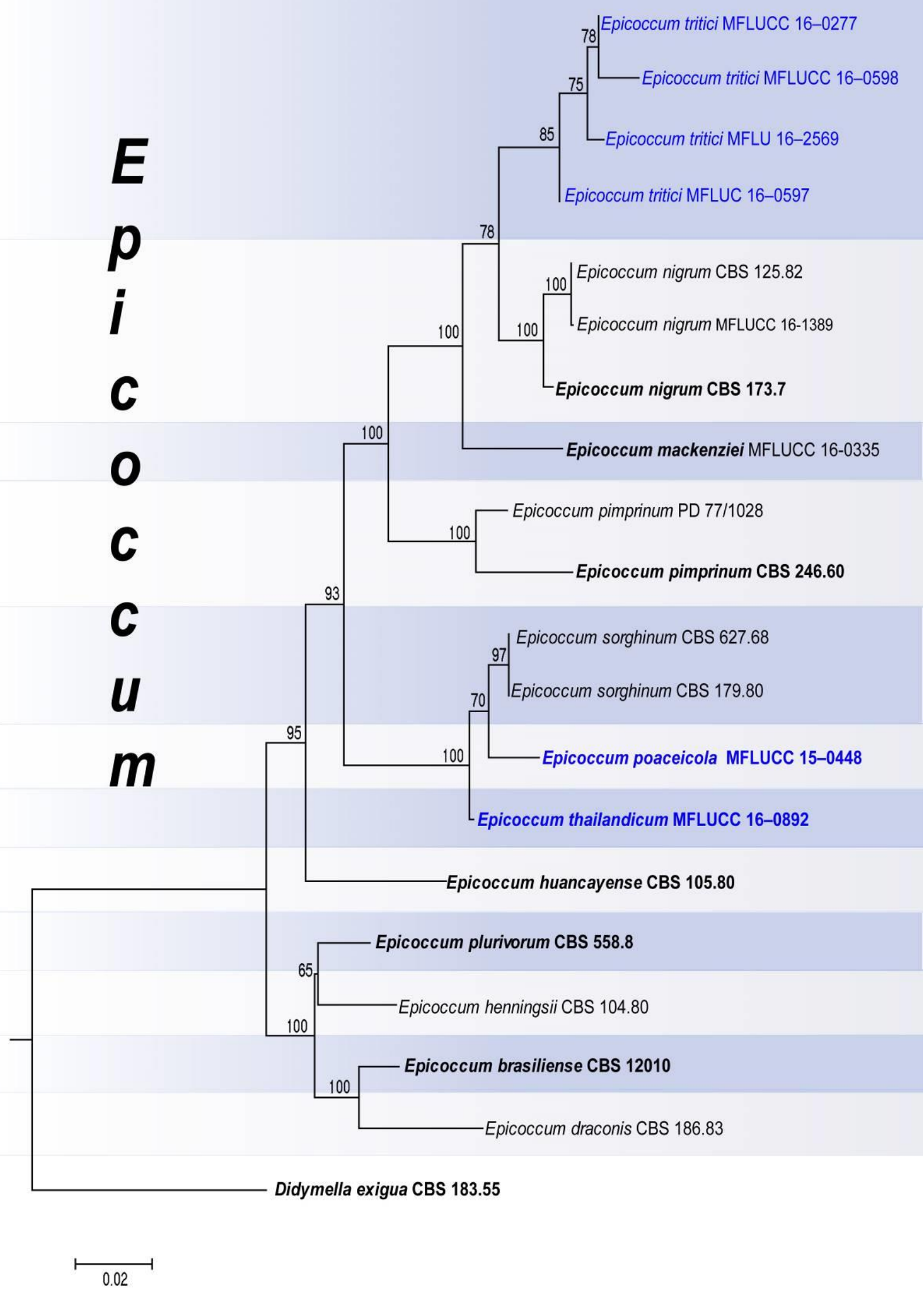

Fig. 8 - Phylogram resulting from maximum likelihood (RAxML) analysis of the combined LSU, ITS, RPB2 and $\beta$-tubulin sequences of 18 strains representing the genus Epicoccum. Maximum likelihood bootstrap support values equal or greater than $50 \%$ are indicated above or below the nodes. The ex-type strains are in bold and the new isolates are in blue. The tree is rooted to Didymella exigua. 

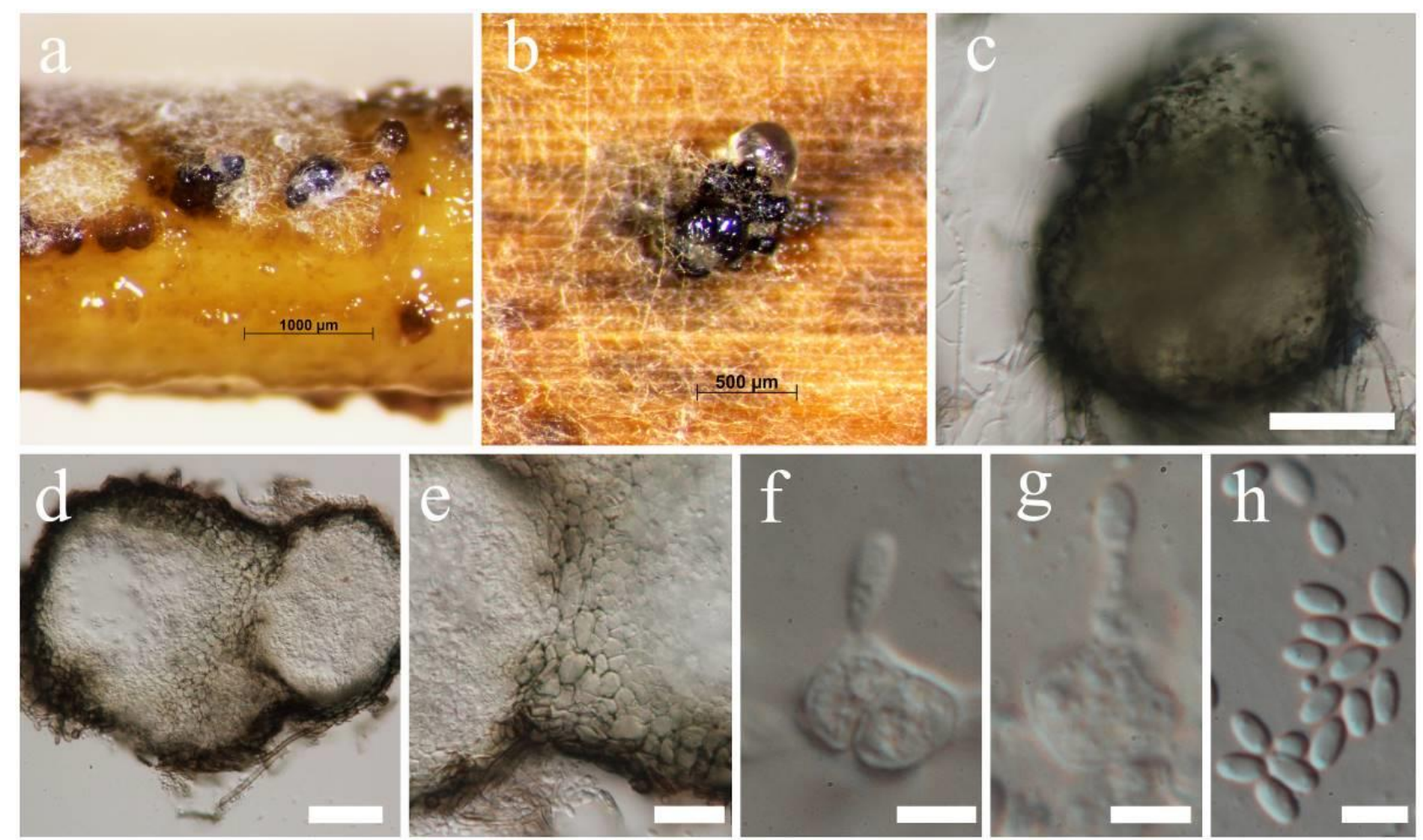

Fig. 9 - Epicoccum poaceicola (MFLU 16-2573, holotype). a. Appearance of conidiomata sporulating on a bamboo branch b. Poaceae host in culture. c. Squash mount of conidioma. d. Vertical section through conidioma. e. Conidiomatal wall. f, g. Conidia developing on conidiogenous cells. $\mathrm{h}$. Conidia. Scale bars: $\mathrm{c}-\mathrm{d}=50 \mu \mathrm{m}, \mathrm{e}=25 \mu \mathrm{m}, \mathrm{f}-\mathrm{h}=5 \mu \mathrm{m}$.

conidiogenous cells. Conidiogenous cells $3-4.5 \times 2-3 \mu \mathrm{m}(\bar{x}=3.5 \times 2.3 \mu \mathrm{m}, \mathrm{n}=10)$, holoblastic, hyaline, doliiform or obpyriform, smooth. Conidia $7.5-10 \times 3-4.5 \mu \mathrm{m}(\bar{x}=8.5 \times 3.5 \mu \mathrm{m}, \mathrm{n}=30)$, oblong, with rounded ends, hyaline, aseptate, guttulate, smooth-walled.

Culture characteristics - Conidia germinating on PDA within $12 \mathrm{~h}$ reaching a diameter of 51 $\mathrm{mm}$ after $7 \mathrm{~d}$ at $25^{\circ} \mathrm{C}$, circular, flat, surface smooth, with entire edge, pale orange at the center and greyish towards the edge, with white margin; reverse yellowish-grey.

Material examined - THAILAND, Chiang Mai Province, Mae Taeng, Mushroom Research Center, on stems of grass litter (Poaceae), 24 March 2016, Ishani D. Goonasekara IGm 30 (MFLU 16-2855 holotype) ibid. (HKAS 97391, isotype), ex-type living culture MFLUCC 16-0892 = KUMCC 17-0026.

Notes - Epicoccum thailandicum is morphologically similar to E. sorghinum, but distinct in conidial dimensions (E. thailandicum 7.5-10 $\times 3-4.5 \mu \mathrm{m}$ and E. sorghinum $5 \times 2 \mu \mathrm{m}$ ) (Saccardo 1878). In the phylogenetic analysis (Fig. 8) carried out in this study, E. thailandicum forms a strongly supported clade (100\% BS) within the genus and therefore, we introduce a new species.

Epicoccum tritici Henn., Hedwigia 43: 146 (1904)

Fig. 11

Facesoffungi number: FoF 03216

Saprobic on Triticum aestivum L. and Zea mays L. Sexual morph: Undetermined. Asexual morph: Sporodochia brownish to black, scattered or aggregated. Stromata 70-140 $\times 65-150 \mu \mathrm{m}$ $(\bar{x}=116 \times 114 \mu \mathrm{m}, \mathrm{n}=8)$, hemispherical to spherical, composed of brown to reddish-brown, pseudoparenchymatous cells. Conidiophores 6-15 $\times 3-6.5 \mu \mathrm{m}(\bar{x}=9.6 \times 4.8 \mu \mathrm{m}, \mathrm{n}=15)$, ampulliform, short, pale brown, arranged as a palisade layer. Conidiogenous cells holoblastic. Conidia $10-19 \times 9-22 \mu \mathrm{m}(\bar{x}=14.2 \times 14.8 \mu \mathrm{m}, \mathrm{n}=50)$, initially yellowish-brown, becoming dark brown, irregularly multi-septate, globose to subglobose, top-shaped with a truncate base, thickly verrucose. 
Culture characteristics - Conidia germinating on PDA within $18 \mathrm{~h}$. Colonies growing on PDA, reaching a diameter of $36 \mathrm{~mm}$ after $4 \mathrm{~d}$ at $25^{\circ} \mathrm{C}$, flat to umbonate, surface smooth to velvety, with entire edge, pinkish white, dense, circular; reverse reddish to brownish, pigmented.
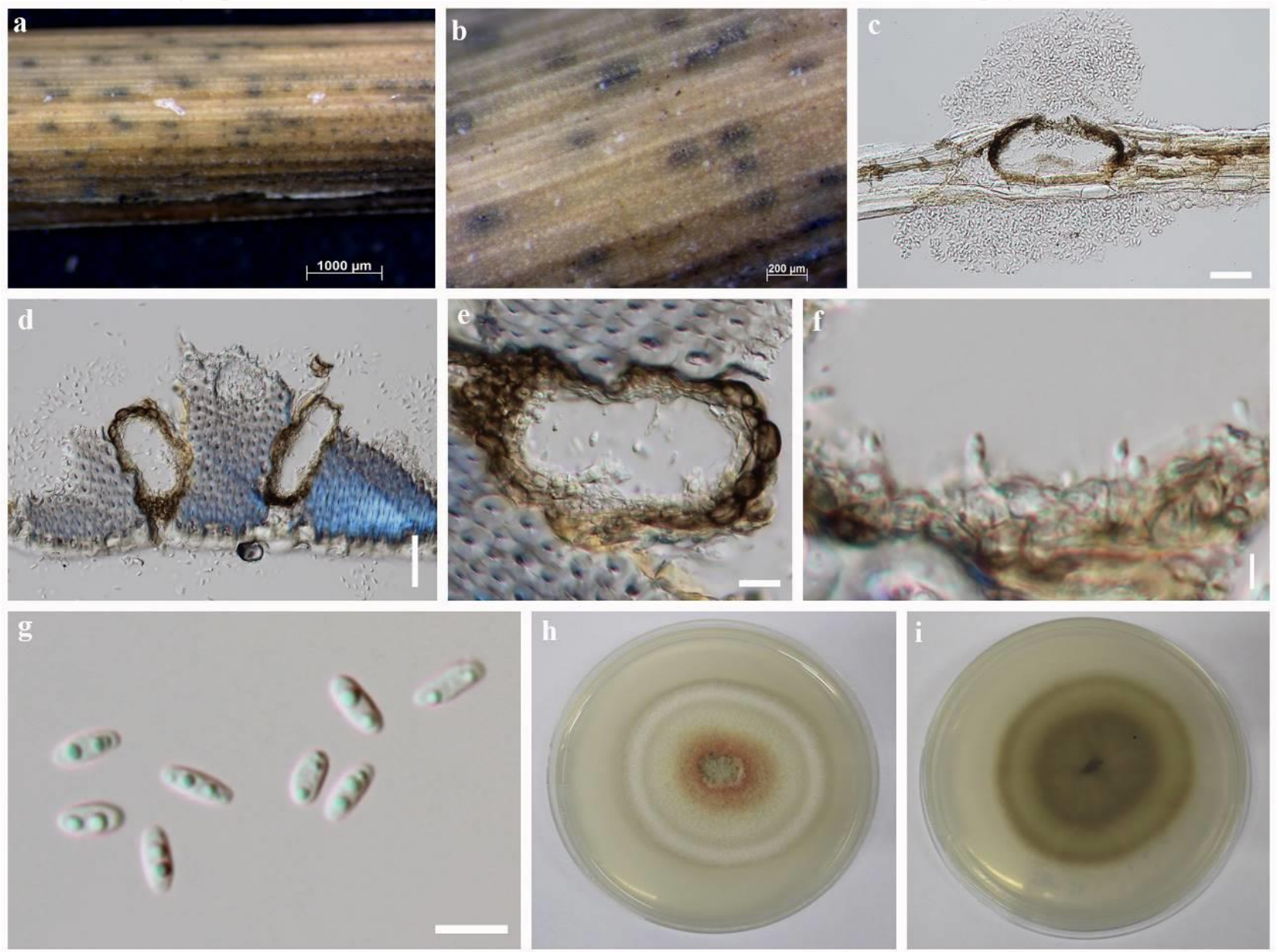

Fig. 10 - Epicoccum thailandicum (MFLU 16-2855, holotype). a, b. Appearance of conidiomata on host c, d. Section through conidiomata e. Vertical section through conidioma showing conidiomal wall. f. Conidia. arising from conidiogenous cells g. Conidia $\mathrm{h}$. Colony from above i. Colony from below. Scale bars: $\mathrm{c}, \mathrm{d}=50 \mu \mathrm{m}, \mathrm{e}=100 \mu \mathrm{m}, \mathrm{f}=5 \mu \mathrm{m}, \mathrm{g}=10 \mu \mathrm{m}$.

Material examined - CHINA, Guizhou Province, Guizhou Academy of Agricultural Sciences, on dead kernels of Triticum aestivum L. (Poaceae), 16 May 2015, K.M. Thambugala CN 004 (MFLU 16-2569, GZAAS 16-0023, epitype designed here), living culture MFLUCC 160276, GZCC 15-0033; ibid., 16 May 2015, K.M. Thambugala CN 005 (MFLU 16-2570, GZAAS 16-0024), living culture MFLUCC 16-0277, GZCC 15-0034; ibid. 10 June 2015, K.M. Thambugala CN 014-2 (MFLU 16-2571, GZAAS 16-0029), living culture MFLUC 16-0597, GZCC 15-0039; ibid., on dead leaves of Zea mays L. (Poaceae), 20 July 2015, K.M. Thambugala CN 018 (MFLU 16-2572, GZAAS 16-0033), living culture MFLUCC 16-0598, GZCC 15-0043

Notes - Epicoccum tritici was introduced by Hennings (1904) on Triticum aestivum L. (wheat) from Japan. During our research, we collected E. tritici in China on Triticum aestivum L. and Zea mays L. The morphology of the present collection fits with original description by Hennings (1904). We therefore designate an epitype (sensu Ariyawansa et al. 2014c) in order to stabilize the name.

Didymosphaeriaceae Munk, Dansk bot. Ark. 15(no. 2): 128 (1953)

The family Didymosphaeriaceae has been revised by Ariyawansa et al. (2014a) who accepted 16 genera. Members of the family are pathogenic or saprobic, in terrestrial or aquatic environments. 


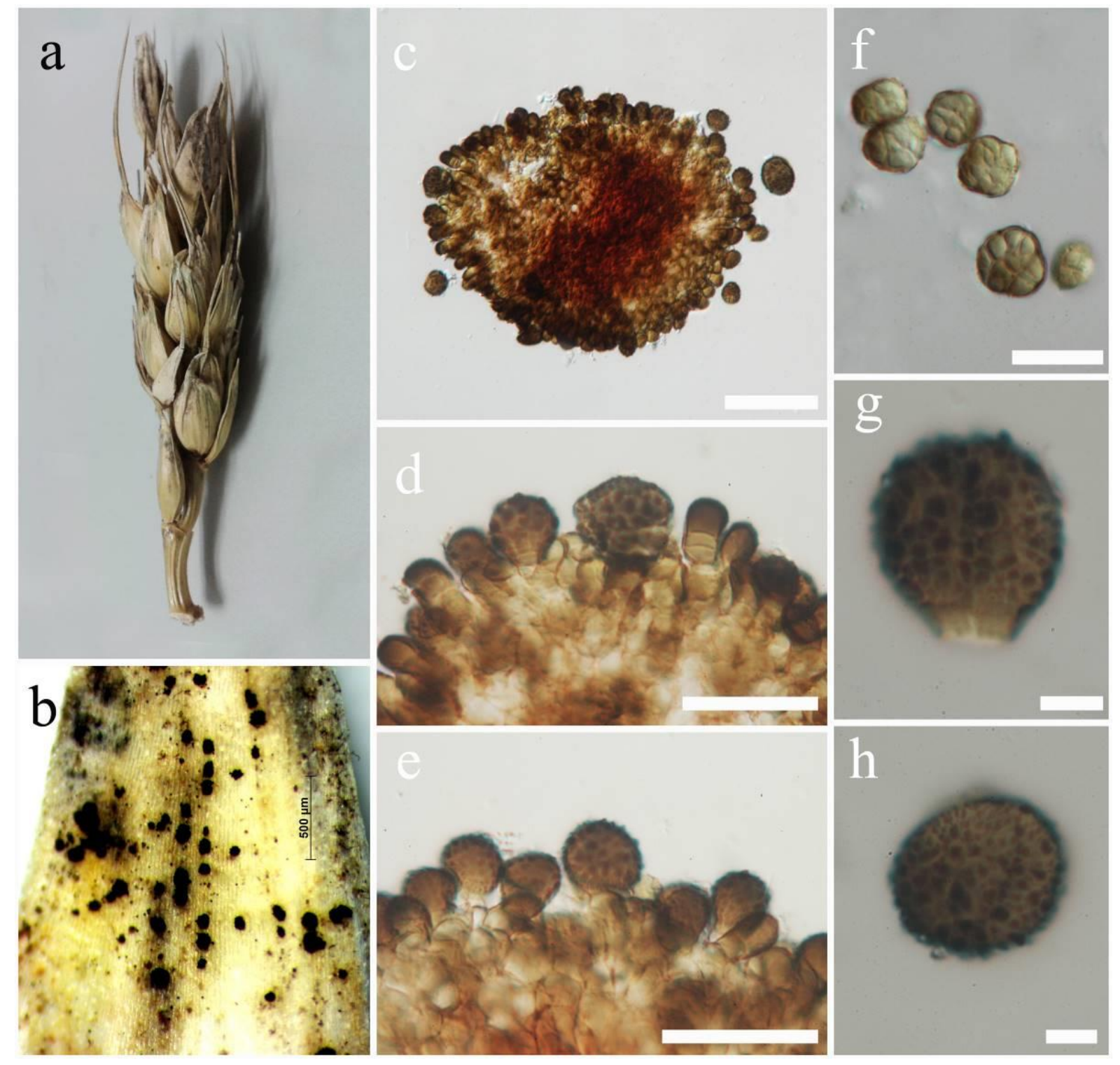

Fig. 11 - Epicoccum tritici (MFLU 16-2569, epitype). a. Habitat (kernel of Triticum aestivum L.). b. Appearance of sporodochia on host. c. Sporodochium. d, e. Conidiophores and developing conidia. f. Young conidia. g, h. Mature conidia. Scale bars: $\mathrm{c}=50 \mu \mathrm{m}, \mathrm{d}$, e $=25 \mu \mathrm{m}, \mathrm{f}=20 \mu \mathrm{m}, \mathrm{g}$, $\mathrm{h}=5 \mu \mathrm{m}$.

Kalmusibambusa Phookamsak, Tennakoon, Thambugala \& K.D. Hyde, gen. nov.

Index Fungorum number: IF553159, Facesoffungi number: FoF 03217

Etymology - In reference to kalmusia-like genus and its Bamboo host.

Associated with living culms ofbamboo. Sexual morph: Ascostromata gregarious, clustered, immersed in clypeus, visible as raised, erumpent to superficial, elongated with a slit-like opening through host surface, multi-loculate, coriaceous, ostiolate. Locules arranged in rows, immersed in clypeus, globose to subglobose, glabrous, with minute papilla. Peridium thin- to thick-walled, of unequal thickness, composed of several layers of small, dark brown to black pseudoparenchymatous cells, arranged in a textura angularis to textura prismatica. Hamathecium composed of dense, broad cellular pseudoparaphyses, filamentous, septate, anastomosing at the apex, embedded in a gelatinous matrix. Asci 8-spored, bitunicate, fissitunicate, cylindrical, with short pedicellate, apically rounded with a well-developed, ocular chamber. Ascospores overlapping 1-2seriate, brown to dark brown, ellipsoidal to fusiform with rounded to acute ends, 3-septate when mature, constricted at the septa, straight to curved, smooth-walled, surrounded by a wide mucilaginous sheath. Asexual morph: Undetermined. 
Type species - Kalmusibambusa triseptata Phookamsak, Tennakoon, \& K.D. Hyde

Notes - Kalmusibambusa is introduced as a monotypic genus to accommodate a bambusicolous species in Didymosphaeriaceae associated with other ascomycetes species causing dieback disease on bamboo culms. Kalmusibambusa is somewhat morphologically similar to Kalmusia, but is easily differentiated by its multi-loculate, coriaceous, elongated ascostromata, with a slit-like opening through host surface and cylindrical asci. Although, in the phylogenetic analysis (Fig. 12), Kalmusibambusa triseptata formed a poorly supported clade, it distinctly separated from Kalmusia and other neighboring genera (Alloconiothyrium Verkley and Xenocamarosporium Crous \& M.J. Wingf). Therefore, based on morphological characters and phylogenetic placement we recognize Kalmusibambusa as a new genus in the family Didymosphaeriaceae.

Kalmusibambusa triseptata Phookamsak, Tennakoon, \& K.D. Hyde, sp. nov.

Fig. 13

Index Fungorum number: IF553160, Facesoffungi number: FoF 03218

Etymology - The specific epithet "triseptata" is based on the 3-septate ascospores

Holotype - MFLU 12-2473

Associated with living culms of bamboo. Sexual morph: Ascostromata 150-210 $\mu \mathrm{m}$ high, $1000-1500 \mu \mathrm{m}$ diameter, gregarious, clustered, immersed in clypeus, visible as raised, erumpent to superficial, elongated with a slit-like opening through host surface, multi-loculate, coriaceous, ostiolate. Locules 100-220 $\mu \mathrm{m}$ high, 190-320 $\mu \mathrm{m}$ diameter, arranged in rows, immersed in clypeus, globose to subglobose, glabrous, with minute papilla. Peridium 12-20 $\mu \mathrm{m}$ wide, thin- to thickwalled, of unequal thickness, slightly thick at the sides, composed of several layers of small, dark brown to black pseudoparenchymatous cells, arranged in a textura angularis to textura prismatica. Hamathecium composed of dense, broad cellular pseudoparaphyses, 1.5-2.5 $\mu \mathrm{m}$ wide, filamentous, distinctly septate, anastomosing at the apex, embedded in a gelatinous matrix. Asci (78-)80-93($95) \times(6.5-) 6.9-7.7(-8.1) \mu \mathrm{m}(\bar{x}=86.5 \times 7.3 \mu \mathrm{m}, \mathrm{n}=30), 8$-spored, bitunicate, fissitunicate, cylindrical, with short pedicellate, apically rounded, with a well-developed ocular chamber. Ascospores (12.5-)13.5-15.5(-16.1) $\times(3.1-) 3.5-4.5(-4.9) \mu \mathrm{m}(\bar{x}=14.5 \times 4 \mu \mathrm{m}, \mathrm{n}=30)$, overlapping 1-2-seriate, ellipsoidal to fusiform with rounded to acute ends, brown to dark brown, 1-septate when young, becoming (2-)3-septate when mature, constricted at the septa, straight to curved, smooth-walled, guttule, surrounded by a wide mucilaginous sheath. Asexual morph: Undetermined.

Culture characteristics - Colonies on PDA fast growing, reaching 75-80 mm diameter after $14 \mathrm{~d}$ at $20-25{ }^{\circ} \mathrm{C}$, colonies medium dense, circular, flat, slightly rough surface with edge entire, well defined margin, glabrous to velvety with smooth aspects, colony from above: light brown to yellowish at the margin, grey to brownish at the centre; reverse, light brown to yellowish at the margin, grey to light brownish at the centre; mycelium white to grey; not producing pigmentation in PDA media agar.

Material examined - THAILAND, Chiang Rai Province, Muang District, Khun Korn Waterfall, on living culms of bamboo, 24 November 2012, R. Phookamsak RP0132 (MFLU 122473, holotype); ibid. (HKAS, isotype), ex-type living culture, MFLUCC 13-0232, KUMCC 160183

Neokalmusia Ariyaw. \& K.D. Hyde, in Ariyawansa et al., Fungal Diversity 68: 92 (2014)

Neokalmusia was established to accommodate two bambusicolous taxa, $N$. brevispora and $N$. scabrispora previously referred to Kalmusia (Ariyawansa et al. 2014a). Dai et al. (2016) introduced, $N$. didymospora D.Q. Dai \& K.D. Hyde associated with decaying bamboo in Thailand.

Neokalmusia arundinis Thambugala \& K.D. Hyde, sp. nov.

Fig. 14

Index Fungorum number: IF553161, Facesoffungi number: FoF 03219

Etymology - Named after Arundo, the host genus from which it was collected.

Holotype - MFLU 16-2577 


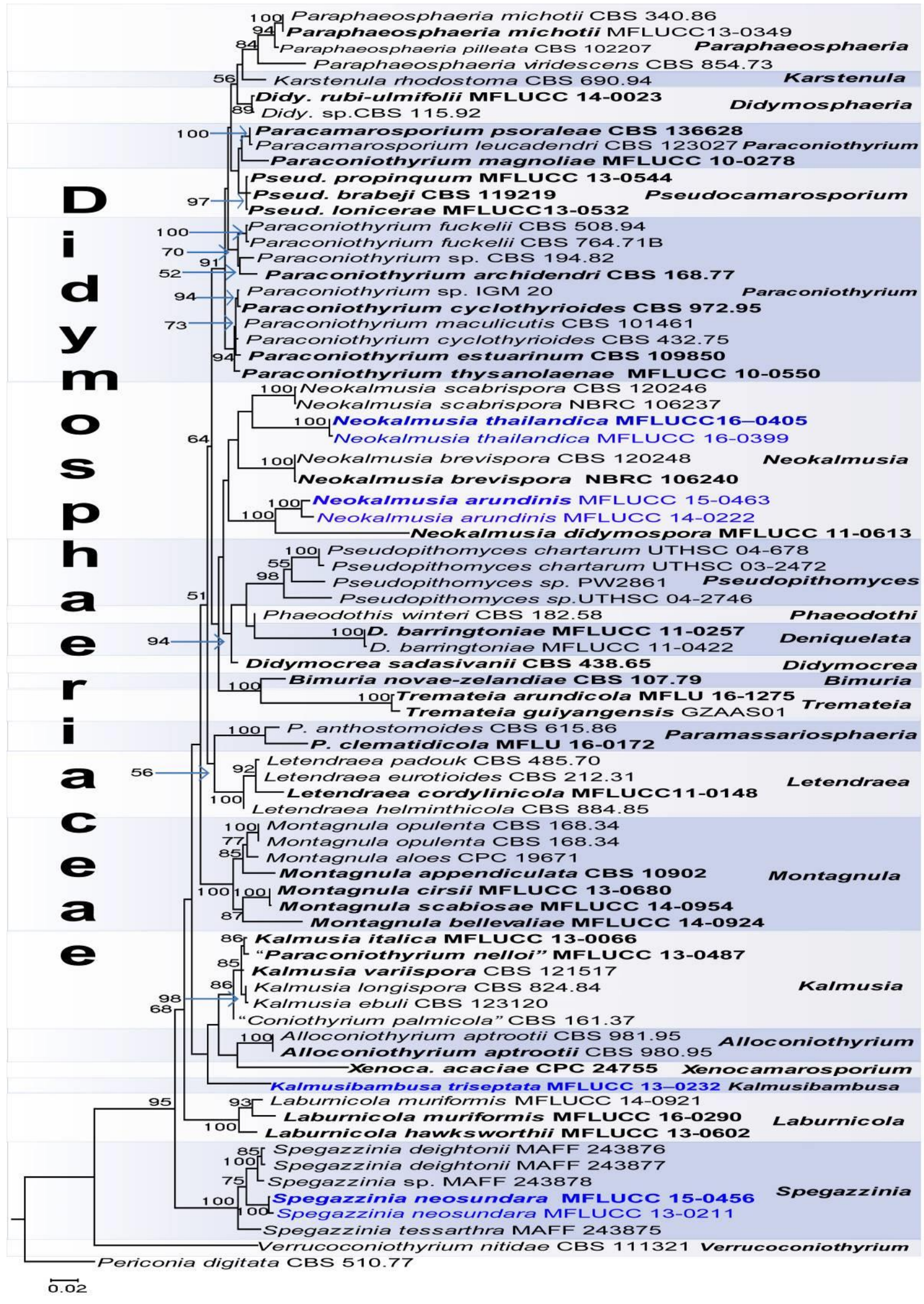

Fig. 12 - Phylogram resulting from maximum likelihood (ML) analysis of the combined LSU, ITS, SSU and EF1- $\alpha$ sequences of 77 strains representing the family Didymosphaeriaceae. Maximum likelihood bootstrap support values equal or greater than $50 \%$ are indicated above or below the nodes. The ex-type strains are in bold and the new isolates are in blue. The tree is rooted to Periconia digitata. 


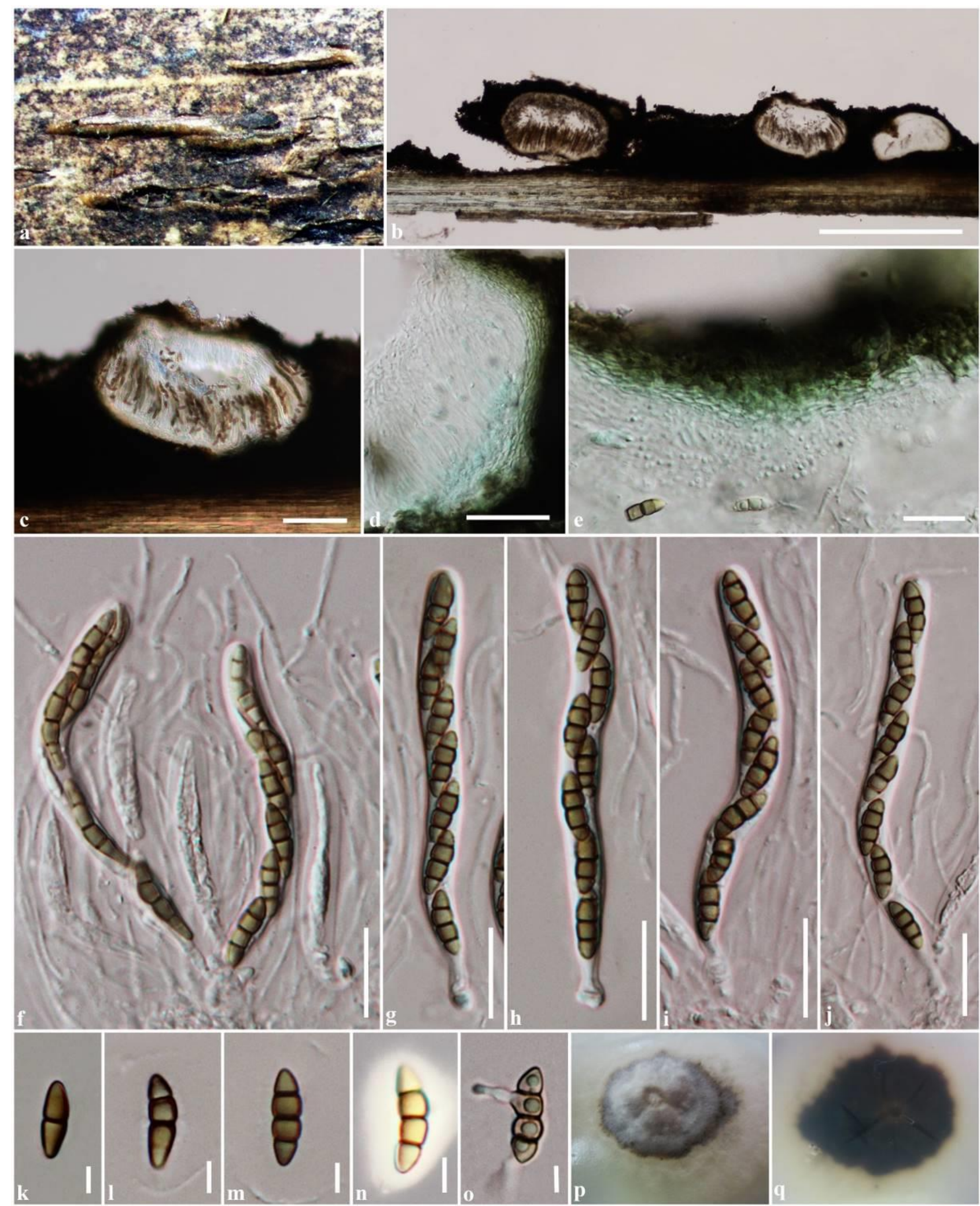

Fig. 13 - Kalmusibambusa triseptata (MFLU 12-2473, holotype). a. Ascostromata on host surface. b. Horizontal section through ascostroma. c Section through ascostroma. d, e. Section of peridium. f. Asci with pseudoparaphyses. g-j. Asci. k-m. Ascospores. n. Ascospore stained with Indian ink. o. Germinated ascospore. p. Colony from above. q. Colony from below. Scale bars: $b=$ $50 \mu \mathrm{m}, \mathrm{c}=100 \mu \mathrm{m}, \mathrm{d}=50 \mu \mathrm{m}, \mathrm{e}-\mathrm{j}=20 \mu \mathrm{m}, \mathrm{k}-\mathrm{o}=5 \mu \mathrm{m}$.

Saprobic on dead stem of Arundo pliniana Turra. Sexual morph: Ascomata 275-350 $\times$ 225-275 $\mu \mathrm{m}(\bar{x}=315 \times 250 \mu \mathrm{m}, \mathrm{n}=5)$, scattered, solitary or in small groups, semi-immersed, 
surrounded by a small, blackened, clypeus-like structure, globose to subglobose, ostiolate. Peridium 15-25 $\mu \mathrm{m}$ wide, poorly developed, composed of few layers of thin-walled, brown to dark brown, cells of textura angularis, fusing at the outside with the host tissue. Hamathecium comprising 2-3 $\mu \mathrm{m}$ wide, numerous, cellular, pseudoparaphyses, embedded in a mucilaginous matrix. Asci $60-85 \times(7.5-)$ 8.5-10.5 $\mu \mathrm{m}(\bar{x}=68 \times 9.2 \mu \mathrm{m}, \mathrm{n}=15)$, 8-spored, bitunicate, fissitunicate, cylindric-clavate, pedicellate, apically rounded with an indistinct ocular chamber. Ascospores 11.8-16.2 $\times 4-5.4 \mu \mathrm{m}(\bar{x}=13.3 \times 4.4 \mu \mathrm{m}, \mathrm{n}=30)$, overlapping 1-2-seriate, fusiform, pale brown to brown, 1-septate, constricted at the septum, often enlarged near septum in the upper cell, smooth-walled, without a mucilaginous sheath. Asexual morph: undetermined.

Culture characteristics - Ascospores germinating on PDA within $18 \mathrm{~h}$ and germ tubes produced from both cells. Colonies growing on PDA, reaching a diameter of $13 \mathrm{~mm}$ after $7 \mathrm{~d}$ at $25{ }^{\circ} \mathrm{C}$, flat to slightly raised, surface smooth to velvety, with entire to slightly irregular margin, white to grey olivaceous, white near the margin, dense, circular to filamentous; reverse black to greenish olivaceous.

Material examined - ITALY, Province of Forlì-Cesena [FC], Fiumana di Predappio, on dead aerial stem of Arundo pliniana Turra (Poaceae), 25 March 2014, Erio Camporesi IT 1584 (MFLU 16-2577, holotype); ibid. (GZAAS 16-0122, isotype), ex-type living culture MFLUCC 15-0463, ICMP 21431; ibid., 19 December 2013, Erio Camporesi IT 1584-2 (16-2578, paratype), living culture MFLUCC 14-0222

Notes - Neokalmusia arundinis is morphologically similar to Montagnula species. However, the ascomatal characters are quite different (Wanasinghe et al. 2016) and phylogenetically Montagnula and Neokalmusia are distinct.

Neokalmusia thailandica Phukhamsakda \& K.D. Hyde, sp. nov.

Index Fungorum number: IF552987, Facesoffungi number: FoF 03220

Fig. 15

Etymology - The epithet "thailandica" refers to the country where the taxon was collected.

Holotype - MFLU 16-2787

Saprobic on dead and dry stem of Bambusoideae. Sexual morph: Ascomata 169-224 $\mu \mathrm{m}$ high $\times 115-208 \mu \mathrm{m}$ diameter $(\bar{x}=197 \times 180 \mu \mathrm{m}, \mathrm{n}=5)$, solitary, scattered, gregarious, immersed, under clypeus, depress globose to sub-globose, coriaceous, uni-loculate, brown to dark brown, shiny, roughened, ostiolate. Ostiole apex well-developed, 69-74 $\mu \mathrm{m}$ high $\times 56-89 \mu \mathrm{m}$ diameter, brown to dark brown, cylindrical, ostiolar canal filled with periphysoids. Peridium $8-11 \mu \mathrm{m}$ wide, composed of 3-5 layers, outer layers composed of irregular, somewhat flattened, dark brown to brown cells, inner layers composed of light brown to hyaline, wider cells of textura angularis. Hamathecium of dense, 1.6-3.5 $\mu \mathrm{m}$ wide $(\bar{x}=2 \mu \mathrm{m}, \mathrm{n}=30)$, transversely septate, branched, filamentous pseudoparaphyses, embedded in a mucilage. Asci $70-93 \times 7-11 \mu \mathrm{m}(\bar{x}=85 \times 10 \mu \mathrm{m}, \mathrm{n}$ $=20$ ), 6-8-spored, bitunicate, fissitunicate, clavate or broad cylindrical, with bulbous pedicel, apically rounded. Ascospores $15-20 \times 5-7 \mu \mathrm{m}(\bar{x}=18 \times 6 \mu \mathrm{m}, \mathrm{n}=40)$, partiallyoverlapping 2seriate, broad fusiform, narrow towards the end, initially hyaline and 1-septate, becoming 3-septate and reddish-brown to brown at maturity, slightly constricted at the septa, constricted at the second septa, finely verrucose, with a thin mucilaginous sheath. Asexual morph: Undetermined.

Culture characteristics - Colonies on MEA, reaching $40 \mathrm{~mm}$ diameter after 2 weeks at $25^{\circ}$ $\mathrm{C}$, surface white, flattened, dense, circular, slightly contain aerial mycelium, entire margins; reverse gray at the center, radiating cream outward, flattened, margin rough.

Material examined - THAILAND, Sukhothai Province, on a dead branches of Bambusoideae (Poaceae), 28 September 2015, C. Phukhamsakda S802 (MFLU 16-2787, holotype), ex-type living culture, MFLUCC 16-0405, ICMP 21564; ibid. (GZAAS 16-0154, isotype); Uttaradit Province, 25 September 2015, C. Phukhamsakda S201 (MFLU 17-0213 paratype), ex-paratype living culture, MFLUCC 16-0399. 


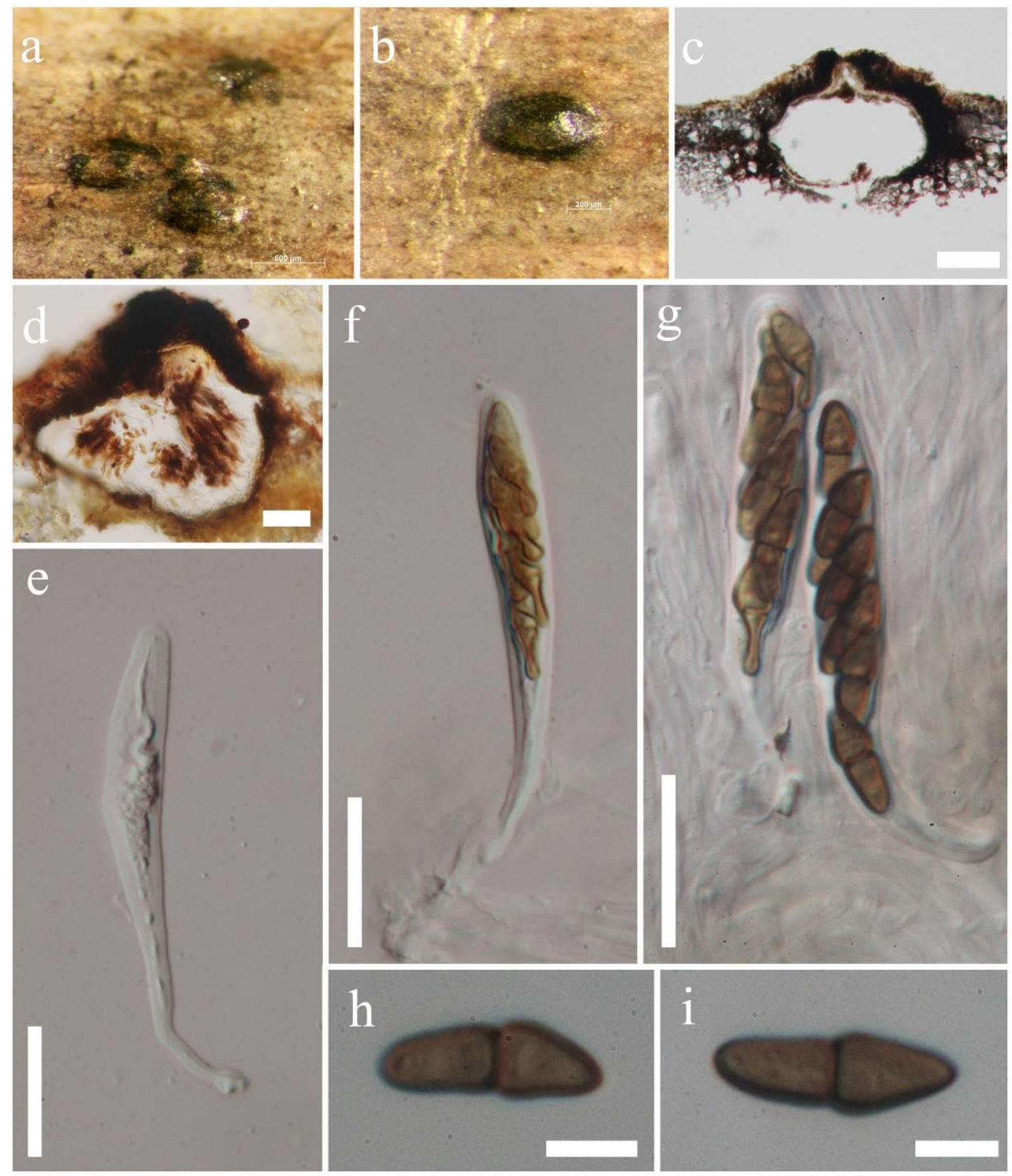

Fig. 14 - Neokalmusia arundinis (MFLU 16-2787, holotype). a, b. Appearance of ascomata on the host surface. c, d. Vertical sections through ascomata. e. Immature ascus f, g. Mature asci (note pseudoparaphyses in g). h, i. Ascospores. Scale bars: $\mathrm{c}=100 \mu \mathrm{m}, \mathrm{d}=50 \mu \mathrm{m}, \mathrm{e}-\mathrm{g}=20 \mu \mathrm{m}, \mathrm{h}-\mathrm{i}=5$ $\mu \mathrm{m}$.

Notes - Other than Neokalmusia thailandica, only one species, N. brevispora (Nagas. \& Y. Otani) Kaz. Tanaka et al. has been reported before with 3-septate ascospores. Neokalmusia brevispora primarily differs from $N$. thailandica in having multi-loculate, larger ascostromata, 4-8-spored asci and somewhat larger ascospores.

Paraphaeosphaeria O.E. Erikss., Ark. Bot. 6: 405 (1967)

Eriksson (1967) introduced the genus Paraphaeosphaeria as a segregate from Leptosphaeria Ces. \& De Not. The immersed to semi-immersed ascomata, bitunicate asci with a short pedicel and multi septate, broadly elliptical, yellowish-brown ascospores are unique morphological traits of the sexual morph (Wong et al. 2000, Ariyawansa et al. 2014a). 

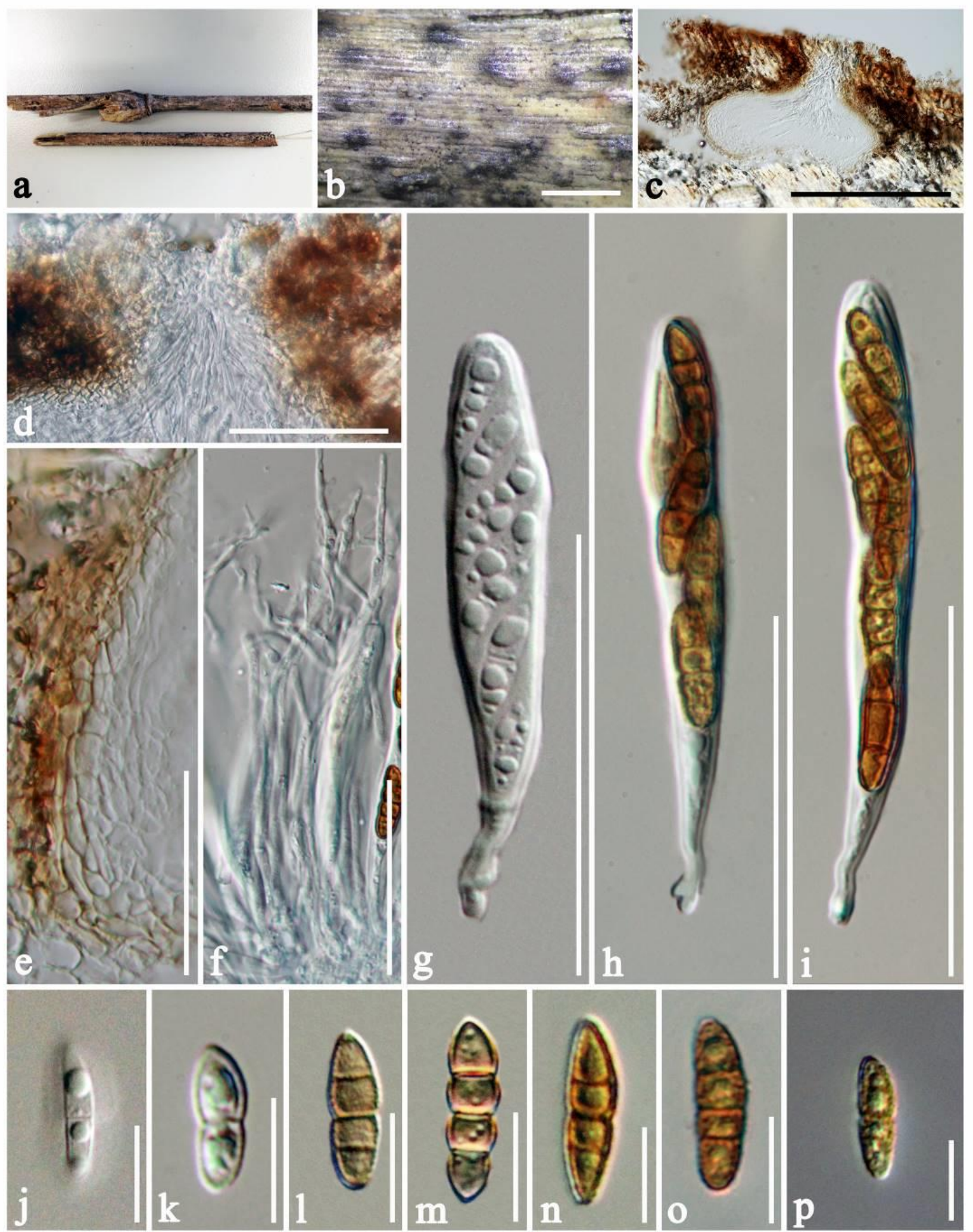

Fig. 15 - Neokalmusia thailandica (MFLU 16-2787, holotype). a. Habitat. b. Appearance of ascomata on the host surface. c. Section of ascoma. d. Ostiole with periphyses. e. Section of partial peridium. f. Pseudoparaphyses. g-i. Developing state of asci with ocular chamber. j-o. Development state of ascospores p. Ascospores stained with Indian ink to show sheath. Scale bar: $b$ $=500 \mu \mathrm{m}, \mathrm{c}=200 \mu \mathrm{m}, \mathrm{e}-\mathrm{i}=50 \mu \mathrm{m}, \mathrm{j}-\mathrm{p}=10 \mu \mathrm{m}$. 
Paraphaeosphaeria produces coniothyrium-like asexual morphs characterized by eustromatic or pycnidial conidiomata, phialidic, or annelidic conidiogenous cells and aseptate or 1-septate conidia Verkley et al. 2014). Recent studies confirmed the placement of Paraphaeosphaeria in Didymosphaeriaceae (Ariyawansa et al. 2014a, Verkley et al. 2014).

Paraphaeosphaeria graminicola Thambugala \& K.D. Hyde, sp. nov.

Fig. 17

Index Fungorum number: IF553162, Facesoffungi number: FoF 03221

Etymology - The specific epithet "graminicola" was given after the host family Gramineae (Poaceae) from which the fungus was collected.

Holotype - MFLU 16-2576

Saprobic on grasses. Sexual morph: Undetermined. Asexual morph: Conidiomata up to 1 mm wide on PDA, pycnidial, solitary, gregarious, or in groups, scattered, immersed to erumpent, uni- to multi-loculate, subglobose to irregular. Locules $(60-) 80-220 \times 60-200 \mu \mathrm{m}(\bar{x}=104 \times 114$ $\mu \mathrm{m}, \mathrm{n}=10$ ), globose to subglobose, ostiolate. Conidiomatal wall 10-20 $\mu \mathrm{m}$ wide, comprising several layers of lightly pigmented to brown, thick-walled, cells of textura angularis. Conidiophores reduced to conidiogenous cells. Conidiogenous cells $4-6.4(-7) \times 4.6-8 \mu \mathrm{m}(\bar{x}=5.4$ $\times 6.3 \mu \mathrm{m}, \mathrm{n}=25$ ), holoblastic, hyaline, smooth, ampulliform to doliiform, lining the conidiomatal cavity. Conidia $2.8-5 \times 1.8-2.5 \mu \mathrm{m}(\bar{x}=4 \times 2.2 \mu \mathrm{m}, \mathrm{n}=60)$, ellipsoidal to cylindrical, initially hyaline, becoming pale brown, thin-walled, smooth, aseptate, with 1-2 small guttules.

Culture characteristics - Conidia germinating on PDA within $18 \mathrm{~h}$. Colonies growing on PDA, reaching a diameter of $60 \mathrm{~mm}$ after $7 \mathrm{~d}$ at $25^{\circ} \mathrm{C}$, flat, surface smooth, with entire edge, white to pale pinkish, moderately dense, circular; reverse white.

Material examined - THAILAND, Chiang Rai Province, Doi Mae Salong, on dead leaves of Poaceae sp., 17 July 2014, K.M. Thambugala KM 019-2 (MFLU 16-2576, holotype); ibid. (GZAAS 16-0121, isotype), ex-type living culture MFLUCC 15-0450, ICMP 21421

Notes - Paraphaeosphaeria species are found on a wide range of substrates and are widely distributed in Europe (Verkley et al. 2014). This is the first record of Paraphaeosphaeria species on Poaceae in Thailand. It is difficult to distinguish asexual morphs of Paraphaeosphaeria using only morphology. In the present phylogeny, $P$. graminicola formed a strongly supported sub-clade (100\% BS) which is sister to P. arecacearum Verkley et al (Fig. 16).

Spegazzinia Sacc., Spegazzinia: [1] (1879)

The hyphomycetous genus Spegazzinia was introduced by Saccardo (1880) and currently 26 species epithets are listed in Index Fungorum (2017). The genus was classified in Apiosporaceae, Sordariomycetes (Hyde et al. 1998) based on its morphological traits. However, the placement of the genus in Didymosphaeriaceae was shown by Tanaka et al. (2015) based on molecular evidence of S. deightonii (S. Hughes) Subram. and S. tessarthra (Berk. \& M.A. Curtis) Sacc. However, only coelomycetous asexual morphs have been reported for the family Didymosphaeriaceae. Therefore, other Spegazzinia species need to be recollected and sequenced to establish their phylogenetic position.

Spegazzinia neosundara Thambugala\& K.D. Hyde, sp. nov.

Fig. 18

Index Fungorum number: IF553163, Facesoffungi number: FoF 03222

Etymology - The species epithet, neo (Lat., new), refers to the similarity to Spegazzinia sundara

Holotype - MFLU 16-2575

Saprobic on dead leaves of Cortaderia sp. Sexual morph: Undetermined. Asexual morph: Sporodochia dark, dense, dry, powdery, velvety, 1-2 mm diameter Conidiophores micronematous. Conidiogenous cells basauxic, ampulate 4-5 $\mu \mathrm{m}$ wide $\times 4.2-6 \mu \mathrm{m}$ high $(\bar{x}=4.5 \times 5 \mu \mathrm{m}, \mathrm{n}=10)$, verrucose, producing an erect, verruculose unbranched filament up to (20-)35-70 $\times 1.5-2.5 \mu \mathrm{m}(\bar{x}$ $=50 \times 2 \mu \mathrm{m}, \mathrm{n}=35$ ), pale, or golden brown. Conidia holoblastic, two types, disc-shaped and stellate-shaped, brown to dark brown, 4-celled, crossed-septate. Disc-shaped conidia 9.5-12.2 $\times$ 


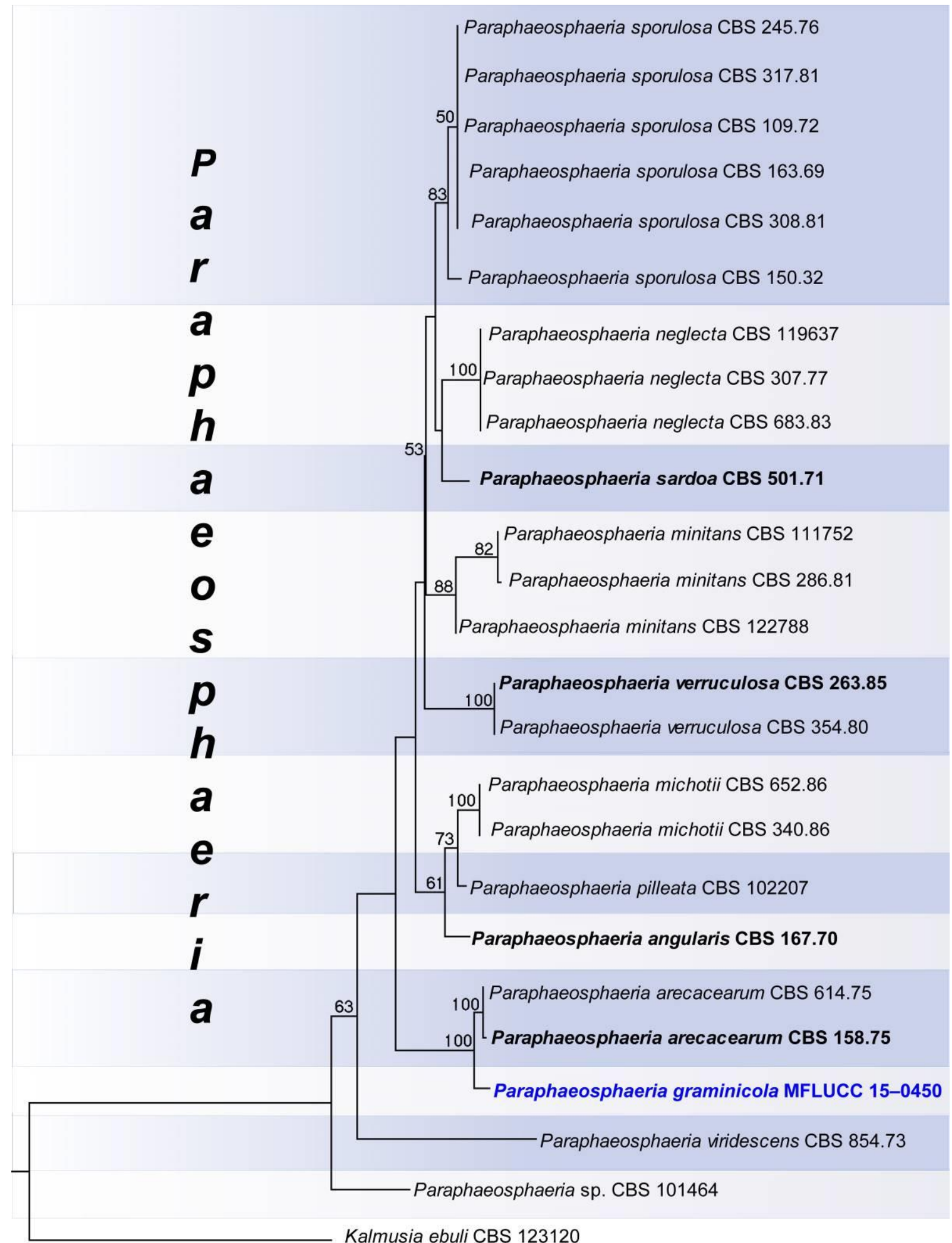

\subsection{2}

Fig. 16 - Phylogram resulting from maximum likelihood (RAxML) analysis of a combined LSU and ITS sequence data of 24 strains representing the genus Paraphaeosphaeria, Didymosphaeriaceae. Maximum likelihood bootstrap values equal or greater than $50 \%$ are indicated above or below the nodes. The ex-type strains are in bold and the new isolates are in blue. The tree is rooted to Kalmusia ebuli. 

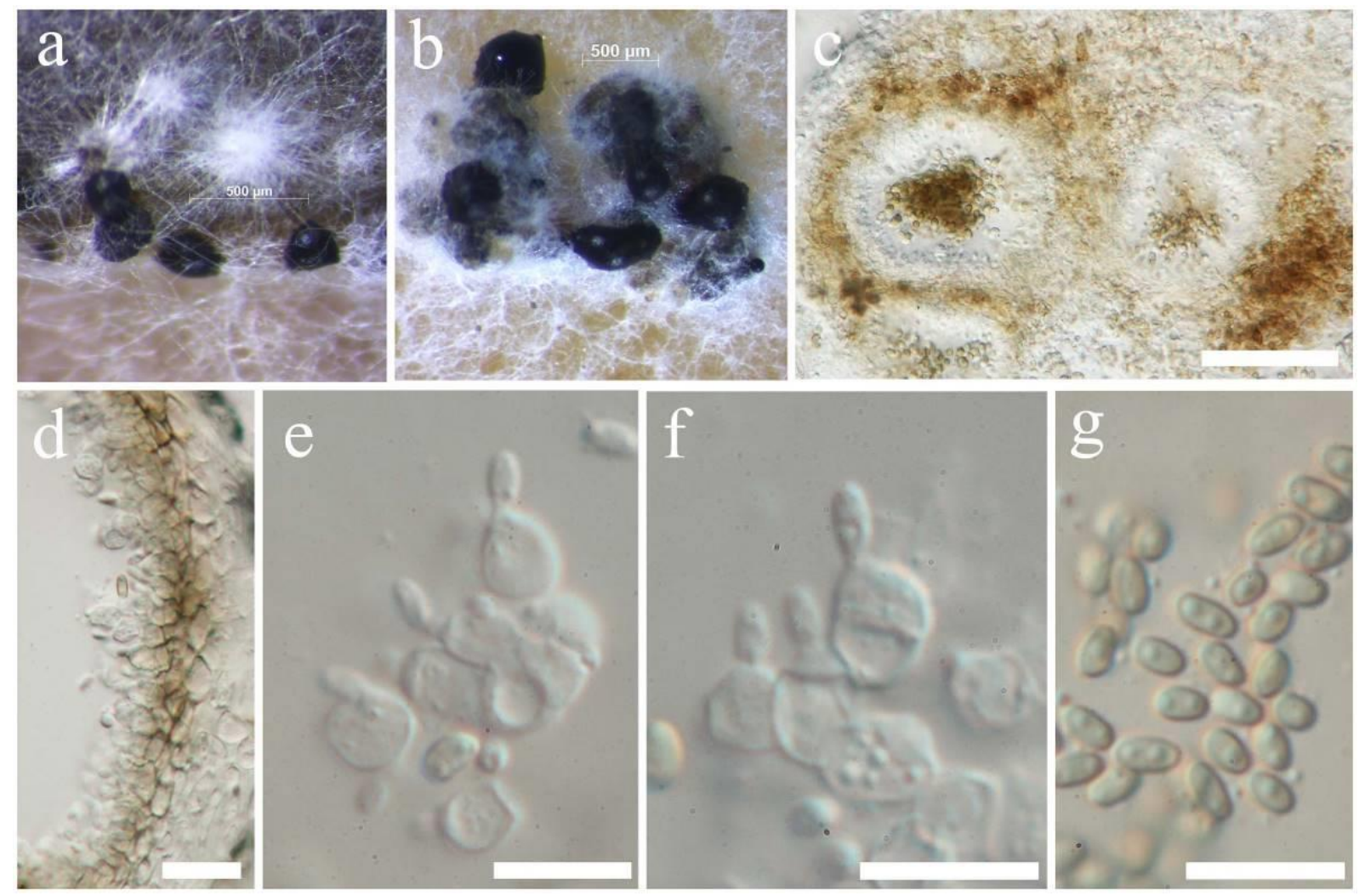

Fig. 17 - Paraphaeosphaeria graminicola (MFLU 16-2576, holotype). Appearance of conidiomata sporulating a. on Poaceae host. b. on PDA. c. Vertical section through conidioma showing locules. d. Conidiomatal wall. e, f Conidiogenous cells and developing conidia. g. conidia. Scale bars: $\mathrm{c}=50 \mu \mathrm{m}, \mathrm{d}=15 \mu \mathrm{m}, \mathrm{e}-\mathrm{g}=10 \mu \mathrm{m}$.

10.2-14 $\mu \mathrm{m}(\bar{x}=11 \times 12 \mu \mathrm{m}, \mathrm{n}=40)$, long, ovoid, deeply constricted at septa, smooth, flat from side view. Stellate-shaped conidia 10.8-17.6 $\times 11.4-19 \mu \mathrm{m}(\bar{x}=13.9 \times 14.8 \mu \mathrm{m}, \mathrm{n}=40)$, ovoid to variedly shaped, conspicuously spinulate, deeply constricted at the septa, with spines measuring up to $2-8 \mu \mathrm{m}$ long.

Culture characteristics - Conidia germinating on PDA within $18 \mathrm{~h}$ and germ tubes produced from one or several septa. Colonies growing on PDA, reaching a diameter of $20 \mathrm{~mm}$ after $10 \mathrm{~d}$ at $25{ }^{\circ} \mathrm{C}$, flat, surface smooth, with entire edge, white to pale greenish-olivaceous, moderately dense, circular; reverse white to greenish olivaceous.

Material examined - THAILAND, Chiang Rai, Mae Fah Luang University, on dead leaves of Cortaderia sp. (Poaceae), 21 December 2014, K.M. Thambugala KM 034 (MFLU 16-2575, holotype), ibid. (GZAAS 16-0120, isotype), ex-type living culture MFLUCC 15-0456; ICMP 21565

Notes - Spegazzinia neosundara is morphologically similar to S. sundara Subram. and $S$. tessarthra, but mainly differs in conidial dimensions (Table 2). In the present phylogenetic analysis, the genus Spegazzinia forms a basal clade in Didymosphaeriaceae and S. neosundara distinctly separates from S. tessarthra and other Spegazzinia species. Unfortunately, no sequence data are available for $S$. sundara, but considering morphological differences we recognize $S$. noesundara as a new species.

\section{Massarinaceae Munk, Friesia 5: 305 (1956)}

In addition to Massarina, the type of Massarinaceae, several genera have been assigned to the family based on molecular phylogenetic studies. Currently Byssothecium, Helminthosporium, Massarina, Pseudodidymosphaeria, Pseudosplanchnonema, Stagonospora and Suttonomyces are accepted in the family (Tanaka et al. 2015, Thambugala et al. 2015b, Wijayawardene et al. 2016). 


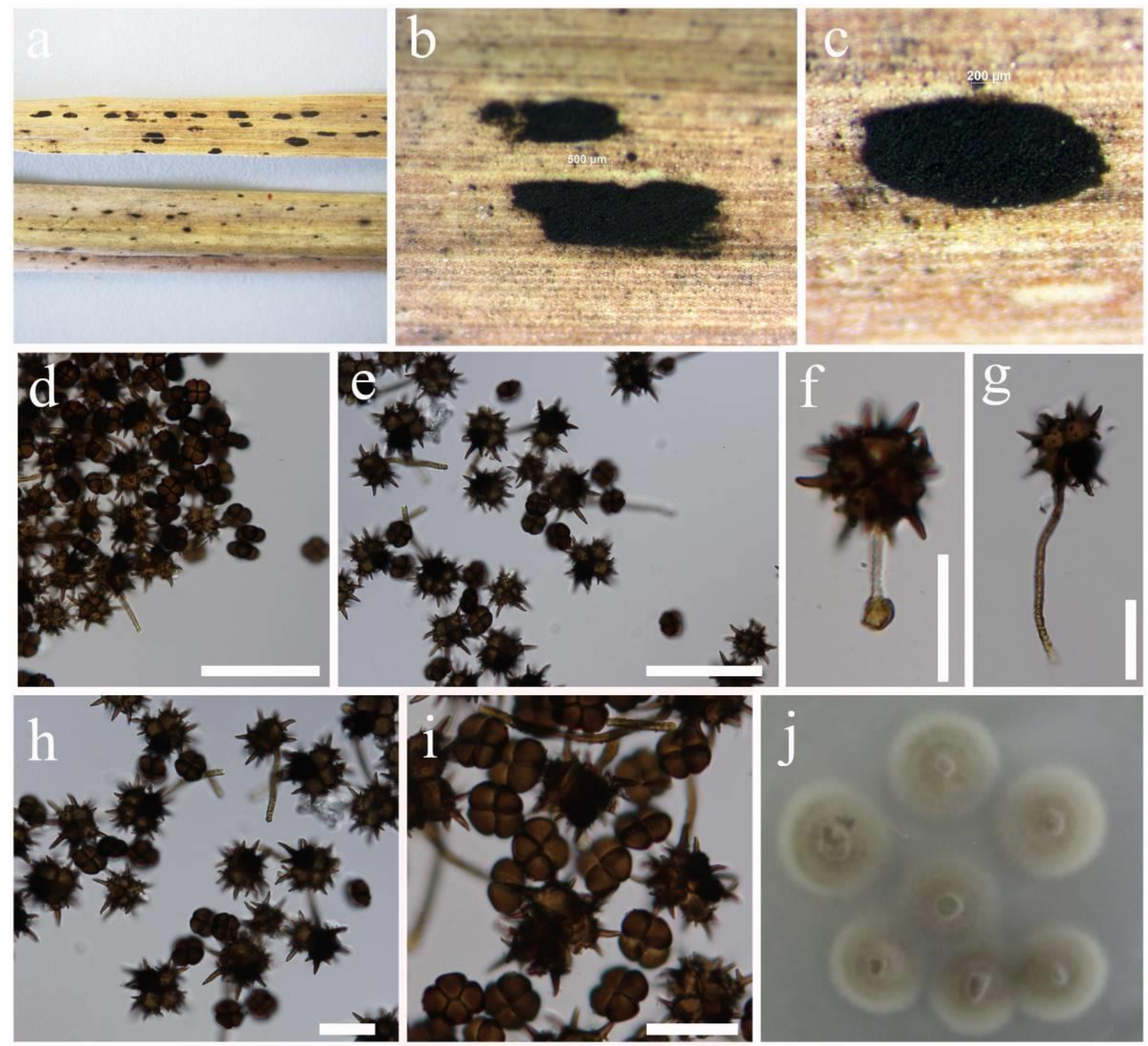

Fig. 18 - Spegazzinia neosundara (MFLU 16-2575, holotype). a-c. Fungal colonies on host surface. d, e, h, i. Conidia. f, g. Conidiogenous cells, developing unbranched filament and conidia (note conidiogenous mother cell in $\mathrm{f}$ ). $\mathrm{j}$. Colonies on PDA. Scale Bars: $\mathrm{d}, \mathrm{e}=100 \mu \mathrm{m}, \mathrm{f}-\mathrm{i}=20 \mu \mathrm{m}$.

Stagonospora (Sacc.) Sacc., Syll. Fung. (Abellini) 3: 445. 1884. nom. Cons

Stagonospora is a species rich genus in the family Massarinaceae and commonly associated with grasses (Quaedvlieg et al. 2013, Tanaka et al. 2015, Hyde et al. 2016). Presently more than 500 epithets are listed in Index Fungorum (2017) for the genus, but there have been few studies confirming species placement with molecular data (Quaedvlieg et al. 2013, Tanaka et al. 2015).

Stagonospora imperaticola Phukhamsakda, Thambugala \& K.D. Hyde, sp. nov.

Fig. 20

Index Fungorum number: IF552986, Facesoffungi number: FoF 03223

Etymology - Named after the host genus, Imperata, from which it was collected.

Holotype - MFLU 16-2788

Habitat parasitic on living leaves of Imperata cylindrica (L.) P. Beauv. Sexual morph: Undetermined. Asexual morph: Conidiomata $120-131 \mu \mathrm{m}$ high $\times 132-212 \mu \mathrm{m}$ wide diameter $(\bar{x}=$ $125 \times 172 \mu \mathrm{m}, \mathrm{n}=10$ ), pycnidial, solitary, scattered, uniloculate, erumpent, globose, base flat with host tissue, rise up from host, dark brown to black, ostiolate. Ostiole central, circular, single. Conidiomatal wall 14-32 $\mu \mathrm{m}$, up to $37 \mu \mathrm{m}$ at the apex, thick-walled, 7-9 layers, comprising of brown cells, of textura angularis, sometimes textura prismatica, inner layer comprising hyaline 
Table 2 - Synopsis of Spegazzinia neosundara, S. sundara and S. tessarthra.

\begin{tabular}{|l|c|c|c|c|c|c|}
\hline \multicolumn{1}{|c|}{ Species } & $\begin{array}{c}\text { Stellate-shaped } \\
\text { conidia }(\mu \mathrm{m})\end{array}$ & $\begin{array}{c}\text { Disc- } \\
\text { shaped } \\
\text { conidia } \\
(\mu \mathrm{m})\end{array}$ & $\begin{array}{c}\text { Spines } \\
(\mu \mathrm{m})\end{array}$ & Distribution & Host recorded & Reference \\
\hline S. sundara & $10-30 \times 10-15$ & $\begin{array}{c}16-25 \times \\
7-10\end{array}$ & $10-12$ & India & $\begin{array}{c}\text { On dead } \\
\text { bamboo }\end{array}$ & $\begin{array}{c}\text { Manoharachary \& } \\
\text { Kunwar }(2010)\end{array}$ \\
\hline S. tessarthra & $10-18$ & $\begin{array}{c}12-17 \times \\
7-9\end{array}$ & $\begin{array}{c}\text { Up to } \\
10\end{array}$ & $\begin{array}{c}\text { India, Cuba, } \\
\text { Venezuela, } \\
\text { Japan }\end{array}$ & $\begin{array}{c}\text { On Zea mays, } \\
\text { balsa } \\
\text { wood }\end{array}$ & $\begin{array}{c}\text { Berkeley \& Curtis } \\
(1868), \text { Saccardo } \\
(1886), \\
\text { Manoharachary \& } \\
\text { Kunwar }(2010), \\
\text { Tanaka et al. } \\
(2015)\end{array}$ \\
\hline S. neosundara & $10.8-17.6 \times$ & $9.5-$ & $2-8$ & Thailand & Cortaderia \\
sp. & This study \\
& $11.4-19$ & $12.2 \times$ & & & & \\
\hline
\end{tabular}

gelatinous layer. Conidiophores reduced to conidiogenous cells. Conidiogenous cells $2-7 \times 4-8$ $\mu \mathrm{m},(\bar{x}=5.9 \times 4.5 \mu \mathrm{m}, \mathrm{n}=20)$, holoblastic, solitary, discrete, oblong, hyaline, formed from the inner layer of conidiomatal wall. Conidia $27-40 \times 8-14 \mu \mathrm{m}(\bar{x}=34.2 \times 11.7 \mu \mathrm{m}, \mathrm{n}=50)$, oblong, obovoid, narrowly rounded at both ends, with 1-2 transverse septa, hyaline, with two small swellings at apex.

Culture characteristics - Conidia geminated on PDA within $18 \mathrm{~h}$, germ tubes developed from the end of conidia. Colonies on PDA reach $40 \mathrm{~mm}$ diameter after 4 weeks. Culture were incubated at $25^{\circ} \mathrm{C}$, initially white, becoming grey after 1 week, fluffy, filiform, raised with concave edge, with aerial mycelium; reverse white at first, after 2 weeks then become black radiating gray.

Material examined - THAILAND, Chiang Rai Province, on living leaves of Imperata cylindrica (L.) P.Beauv. (Poaceae), 18 December 2014, C. Phukhamsakda CP004 (MFLU 162788, holotype); ibid. (GZAAS 16-0153, isotype), ex-type living culture, MFLUCC 15-0026, ICMP 21563

Notes - Stagonospora imperaticola is phylogenetically close to S. tainanensis W.H. Hsieh. It formed a sister clade to $S$. tainanensis (MAFF 243860) with $76 \%$ BS support. Stagonospora tainanensis differs from $S$. imperaticola mainly in having 3-septate conidia. Stagonospora imperaticola was found associated with Imperata cylindrical (L.) P. Beauv. and causes ring spots on host tissues. S. tainanensis was found on Saccharum species (Hsieh 1979, Tanaka et al. 2015).

Stagonospora multiseptata Thambugala \& K.D. Hyde, sp. nov.

Fig. 21

Index Fungorum number: IF553164, Facesoffungi number: FoF 03224

Etymology - In reference to the multi-septate conidia.

Holotype - MFLU 16-2582

Saprobic on leaves and stems of grasses. Sexual morph: Undetermined. Asexual morph: Conidiomata up to $1 \mathrm{~mm}$ wide on PDA, pycnidial, solitary, scattered, immersed to erumpent, unito multi-loculate, subglobose to irregular. Locules (60-)100-330 $\times(70-) 100-350 \mu \mathrm{m}(\bar{x}=180 \times$ $184 \mu \mathrm{m}, \mathrm{n}=12$ ), subglobose, broadly conical, ostiolate. Conidiomatal wall 25-75 $\mu \mathrm{m}$ wide, comprising several layers; inner layer composed of dark brown, thick-walled, flattened cells of textura angularis; outer layer of hyaline, thin-walled, wide cells of textura angularis. Conidiophores reduced to conidiogenous cells. Conidiogenous cells $9-21 \times 3-5.5 \mu \mathrm{m}(\bar{x}=14 \times 3.8$ $\mu \mathrm{m}, \mathrm{n}=20$ ), holoblastic, discrete, subcylindrical, hyaline, smooth, formed from the inner wall cells of the pycnidium. Conidia 37-55 $\times 7.4-10.8 \mu \mathrm{m}(\bar{x}=46.8 \times 9 \mu \mathrm{m}, \mathrm{n}=35)$, cylindrical or fusoidellipsoidal, hyaline, aseptate when immature, becoming (3-)4-septate at maturity, not constricted at the septa, rounded at both ends, straight or slightly curved, smooth, often guttulate. 


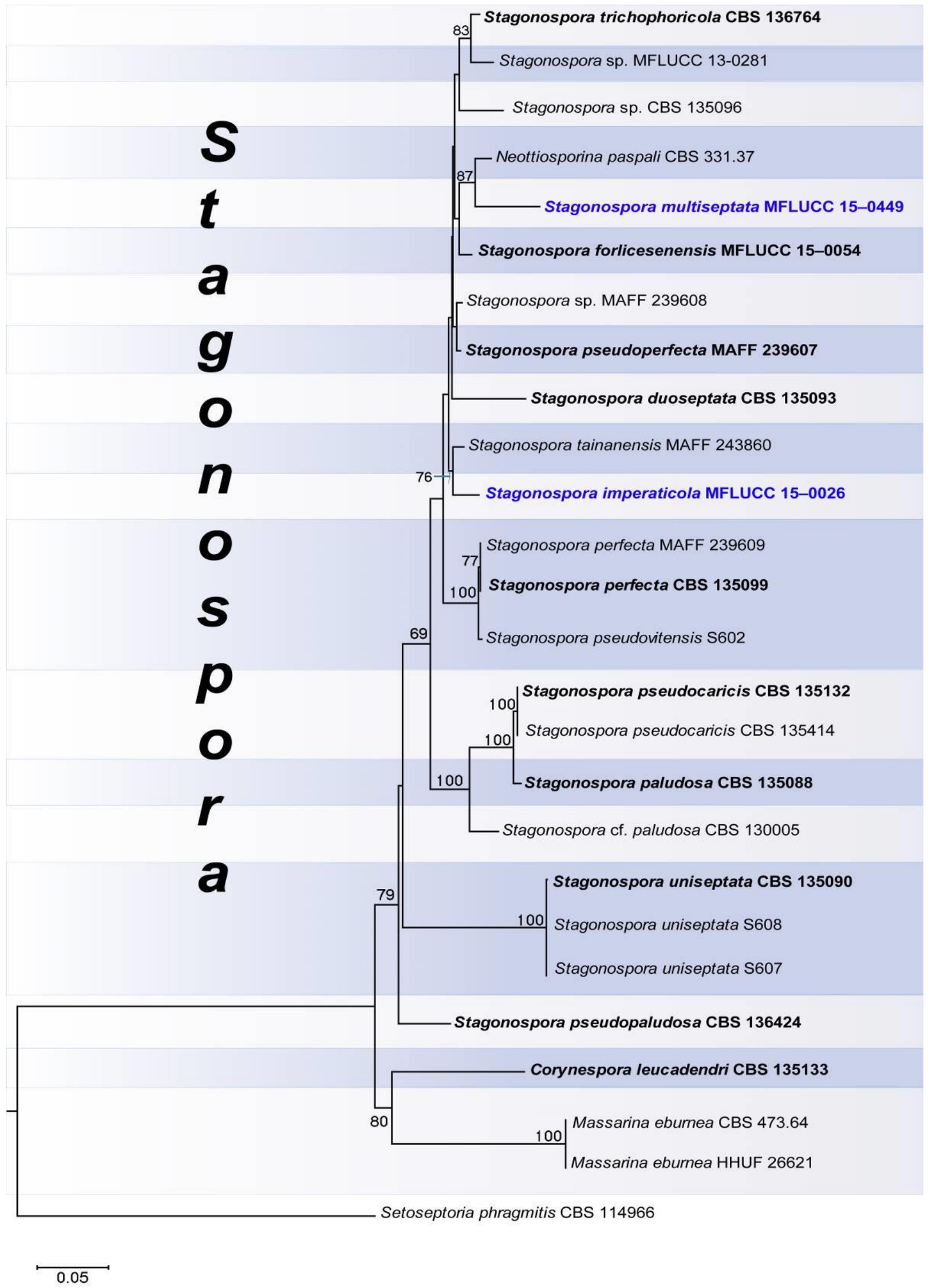

Fig. 19 - Phylogram resulting from maximum likelihood (ML) analysis of a combined LSU, ITS, $\beta$-tubulin and RPB2 dataset of Stagonospora in Massarinaceae. Bootstrap support values equal or greater than $50 \%$ are given above or below the nodes. The ex-type strains are in bold and the new isolates are in blue. The tree is rooted to Setoseptoria phragmitis. 

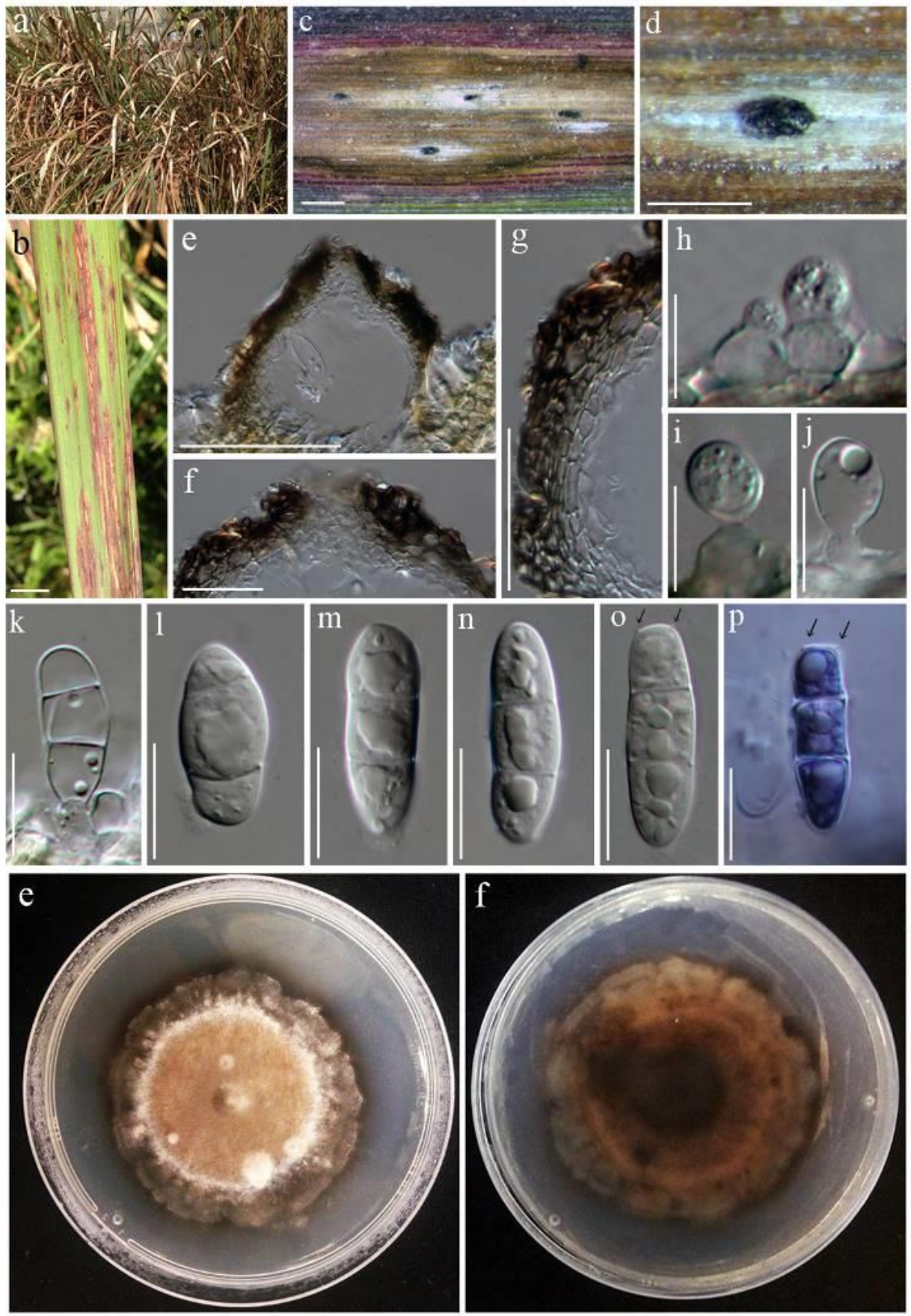

Fig. 20 - Stagonospora imperaticola (MFLU 16-2788, holotype). a. Habitat b. Leaves with character of ring spots disease. c, d. Close up of conidiomata erumpent through the host surface. e. Vertical section of conidioma. f. Ostiole. g. Conidiomatal wall. $\mathrm{h}-\mathrm{k}$. Conidiogenous cell with developing conidia. $1-\mathrm{o}$. Conidia p. Conidia stained in Indian ink (note small swellings in o and p). Scale bar: $\mathrm{b}=500 \mu \mathrm{m}, \mathrm{c}-\mathrm{d}=200 \mu \mathrm{m}, \mathrm{e}=100 \mu \mathrm{m}, \mathrm{f}, \mathrm{g}=50 \mu \mathrm{m}, \mathrm{h}-\mathrm{j}=10 \mu \mathrm{m}, \mathrm{k}-\mathrm{p}=20 \mu \mathrm{m}$.

Culture characteristics - Conidia germinating on PDA within $24 \mathrm{~h}$. Colonies growing on PDA, reaching a diameter of $48 \mathrm{~mm}$ after $10 \mathrm{~d}$ at $25{ }^{\circ} \mathrm{C}$, umbonate, surface velvety, with entire to slightly undulate edge, white to grey, white near the margin, dense, circular to slightly irregular; reverse black to grey olivaceous.

Material examined - THAILAND, Chiang Rai, Mae Fah Luang University, on dead leaves of Poaceae sp., 17 July 2014, K.M. Thambugala KM 019-1 (MFLU 16-2582, holotype); ibid. (GZAAS 16-0124, isotype), ex-type living culture MFLUCC 15-0449, ICMP 21562 

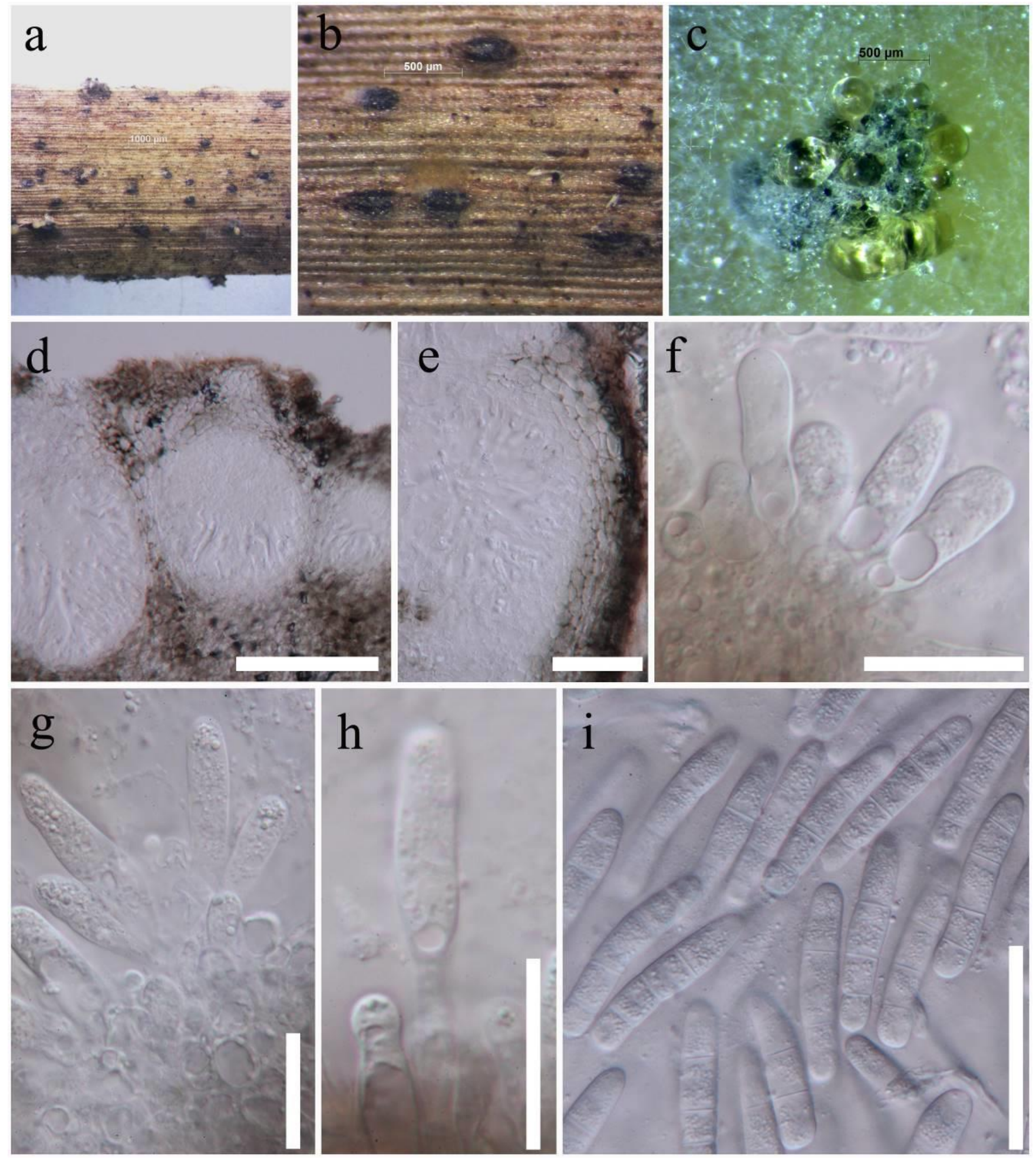

Fig. 21 - Stagonospora multiseptata (MFLU 16-2582, holotype). Appearance of conidiomata. a, b. On host surface c. On PDA d. Vertical section through conidioma showing locules. e. Conidiomatal wall. $\mathrm{f}-\mathrm{h}$. Different stages of conidiogenesis. i. Conidia. Scale bars: $d=100 \mu \mathrm{m}$, e, $\mathrm{i}$ $=50 \mu \mathrm{m}, \mathrm{f}, \mathrm{g}-\mathrm{h}=20 \mu \mathrm{m}$.

Notes - Multiloculate conidiomata and (2-)3-4-septate, cylindrical or fusoid-ellipsoidal conidia are unique to $S$. multiseptata and in the present phylogenetic analysis it forms a sister clade to Neottiosporina paspali (CBS 331.37) with $87 \%$ BS support (Fig. 19). Therefore, we introduce $S$. multiseptata as a new species. 
Mycosphaerellaceae Lindau, in Engler \& Prantl, Nat. Pflanzenfam., Teil. I (Leipzig) 1(1): 421 (1897)

The family Mycosphaerellaceae contains numerous genera and the family comprises species that are biotrophic and necrotrophic plant pathogens, as well as saprobes (Crous et al. 2009, Hyde et al. 2013). Hawksworth et al. (1995) placed Mycosphaerellaceae in Dothideales, while recent studies excluded the family from Dothideales (Thambugala et al. 2014b) and placed it in Capnodiales (Kirk et al. 2008, Crous et al. 2009, Hyde et al. 2013).

Neoramichloridium Phookamsak, Thambugala \& K.D. Hyde, gen. nov.

Index Fungorum number: IF553183, Facesoffungi number: FoF 03210

Etymology - The generic epithet, neo (Lat., new), refers to the similarity to Ramichloridium.

Leaf spots on bamboo, amphigenous, small to large, elongated to irregular, pale brown, with or without a definite margin. Sexual morph: Undetermined. Asexual morph: Conidiophores aggregated, in loose fascicles, erect, flexuous, subcylindrical, brown to pale brown, septate. Conidiogenous cells integrated, terminal, polyblastic, hyaline to pale brown denticulate, subcylindrical; conidiogenous loci sympodial, forming a short rachis with darkened, thickened, refractive tips. Conidia single, hyaline to subhyaline, obovoid to clavate, base truncate, with unthickened, non-pigmented hilum, smooth-walled.

Type species - Neoramichloridium bambusicola Thambugala, Phookamsak \& K.D. Hyde

Notes - Neoramichloridium is introduced here as a novel genus based on morphology and phylogeny. In the present phylogenetic analysis based on LSU and ITS sequence data, Neoramichloridium bambusicola (MFLUCC 15-0455) forms a strongly supported clade (96\% BS) separate from other genera of Mycosphaerellaceae (Fig. 22). Based on morphology. Neoramichloridium differs from Zasmidium in having aggregated, flexuous, conidiophores and hyaline to subhyaline, obovoid to clavate, aseptate, singly conidia (Arzanlou et al. 2007, Crous et al. 2009). Neoramichloridium differs from Periconiella based on its aggregated, unbranched conidiophores, whereas Periconiella is distinct from Neoramichloridium, Ramichloridium sensu lato and Zasmidium in having conidiophores prominently branched in the upper part and conidial scars darkened, thickened (Arzanlou et al. 2007). Neoramichloridium resembles Ramichloridium in having unbranched conidiophores and aseptate conidia, but differs in having aggregated conidiophores with unthickened, non-pigmented hilum (Arzanlou et al. 2007, Crous et al. 2009). Ramichloridium sensu stricto belongs to the family Dissoconiaceae, whereas Neoramichloridium belongs to Mycosphaerellaceae.

Neoramichloridium bambusicola Thambugala, Phookamsak \& K.D. Hyde, sp. nov.

Fig. 23

Index Fungorum number: IF553184, Facesoffungi number: FoF 03225

Etymology - The specific epithet bambusicola was given after the host bamboo on which the fungus was collected.

Holotype - MFLU 16-2278

Leaf spots amphigenous, small to large, elongated to irregular, pale brown, with or without a definite margin. Sexual morph: Undetermined. Asexual morph: Conidiophores 35-60 × 1.7-3.2 $\mu \mathrm{m}(\bar{x}=44 \times 2.4 \mu \mathrm{m}, \mathrm{n}=15)$, aggregated, in loose fascicles, erect, flexuous, subcylindrical, brown to pale brown, septate. Conidiogenous cells integrated, terminal, polyblastic, hyaline to pale brown denticulate, subcylindrical; conidiogenous loci sympodial, forming a short rachis with darkened, thickened, refractive tips. Conidia 3.5-8(-11) $\times 1.7-2.7 \mu \mathrm{m}(\bar{x}=5.1 \times 2.1 \mu \mathrm{m}, \mathrm{n}=50)$, single, hyaline to subhyaline, obovoid to clavate, base truncate, with unthickened, non-pigmented hilum, smooth-walled. 


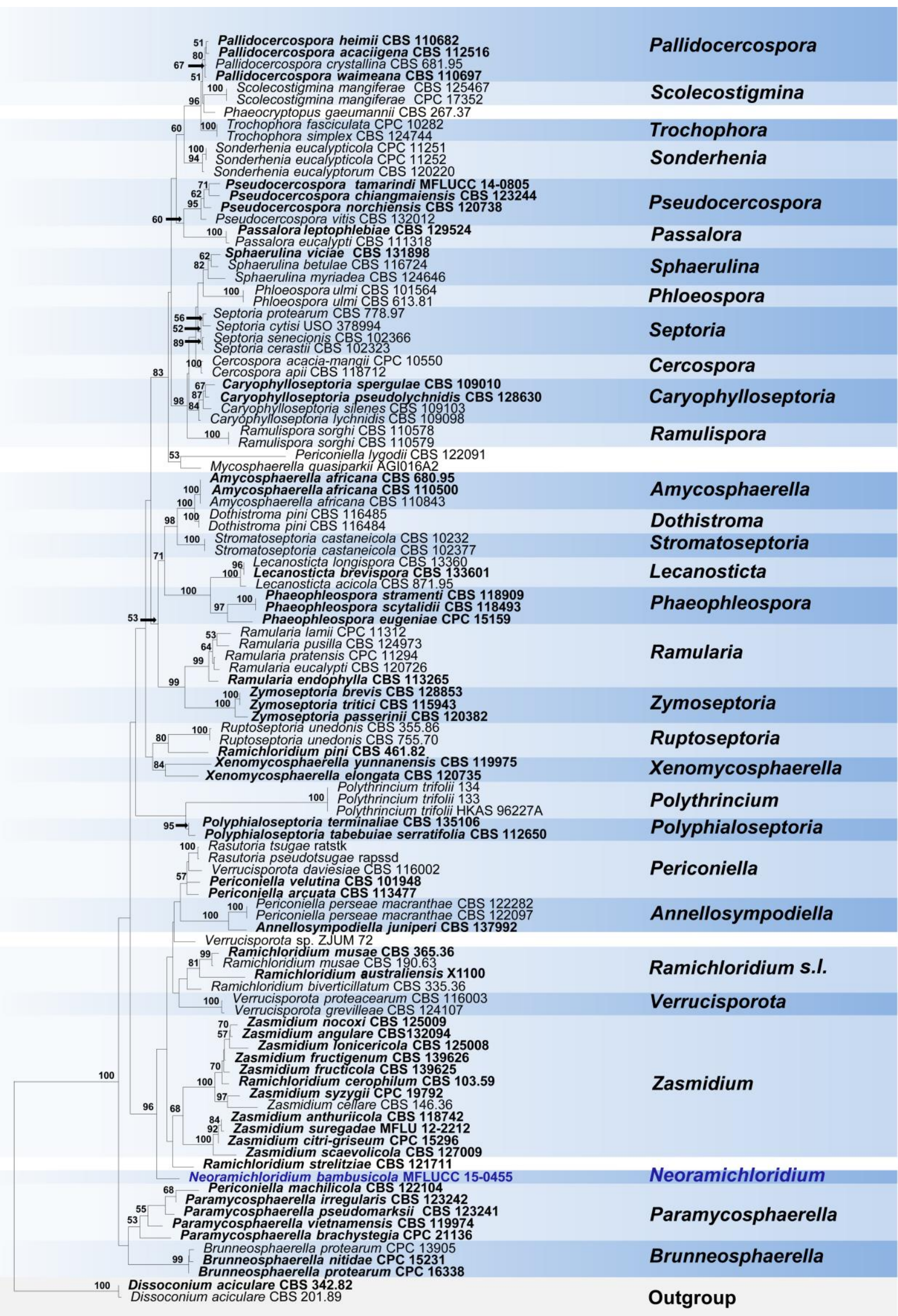

Fig. 22 - Phylogram resulting from maximum likelihood (ML) analysis of a combined LSU and ITS dataset of Mycosphaerellaceae. Bootstrap support values equal or greater than $50 \%$ are given above or below the nodes. The ex-type strains are in bold and the new isolates are in blue. The tree is rooted to Dissoconium aciculare. 

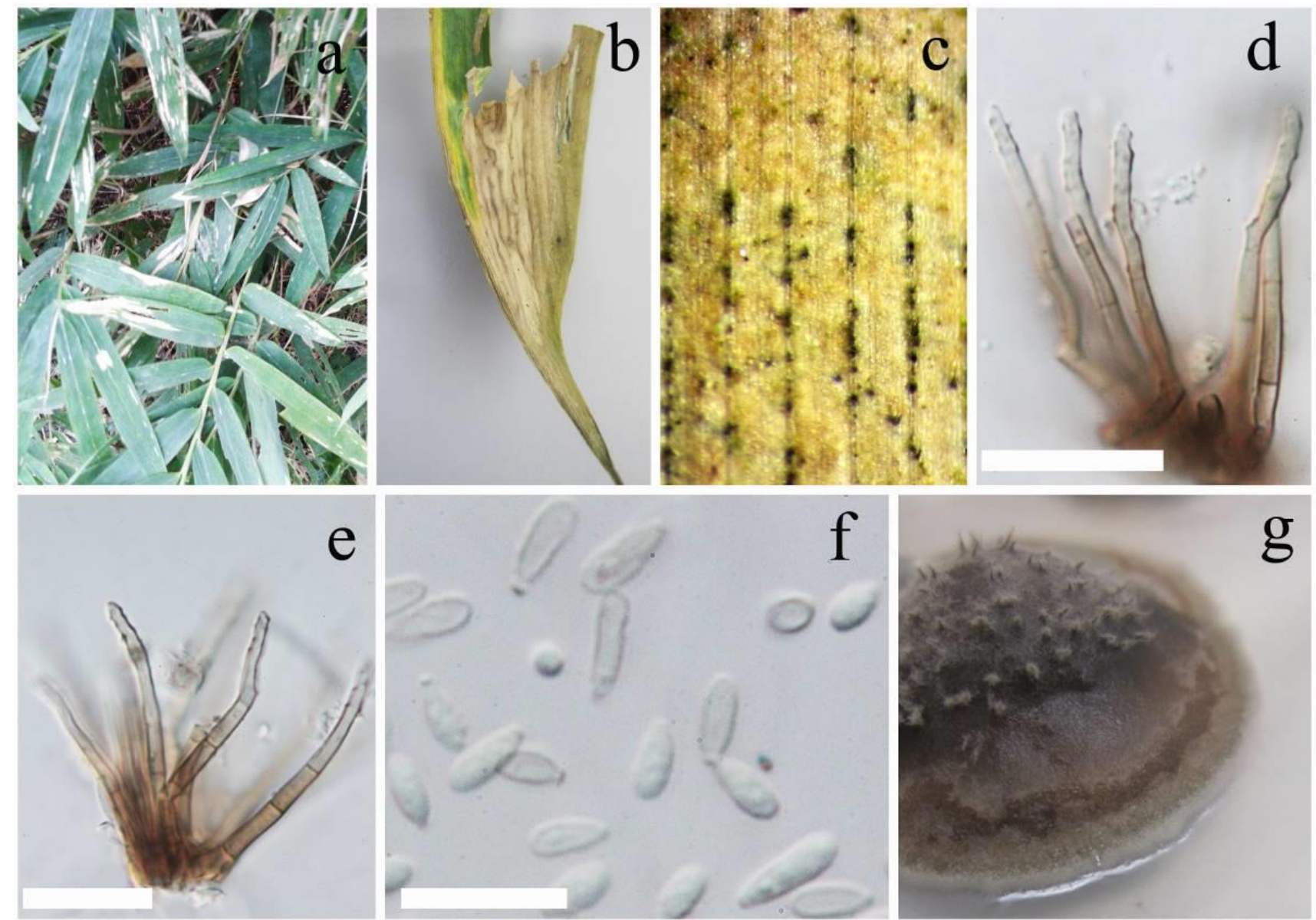

Fig. 23 - Neoramichloridium bambusicola (MFLU 16-2278, holotype), a, b. Habitat. c. Appearance of Sporodochia on host. d, e. Conidiophores. f. Conidia. Scale bars: $d, e=20 \mu \mathrm{m}, \mathrm{f}=$ $10 \mu \mathrm{m}$.

Culture characteristics - Conidia germinating on PDA within $24 \mathrm{~h}$. Colonies growing on PDA, reaching a diameter of $15 \mathrm{~mm}$ after $14 \mathrm{~d}$ at $25{ }^{\circ} \mathrm{C}$, umbonate, surface velvety to rough, with slightly undulate to lobate edge, brown, pale brown near the margin, dense, slightly irregular; reverse grey to black.

Material examined - THAILAND, Chiang Rai Province, Mae Fah Luang University, on leaves of Bambusa sp. (Poaceae), 12 December 2014, K.M. Thambugala KM 033 (MFLU 162278, holotype); ibid. (GZAAS 16-0155, isotype), ex-type living culture, MFLUCC 15-0455, ICMP 21407

Periconiaceae (Sacc.) Nann., Repertorio sistematico dei miceti dell'uomo e degli animali 4: 482 (1934)

= Periconieae Sacc., Syll. Fung. 4: 235. 1886.

The taxonomic placement of the family Periconiaceae was shown by Tanaka et al. (2015) in the suborder Massarineae as a sister taxon of the family Massarinaceae. Bambusistroma, Flavomyces, Noosia and Periconia were accepted in this family.

Periconia Tode, Fung. mecklenb. sel. (Lüneburg) 2: 2 (1791)

The genus Periconia was introduced by Tode (1791) and known as hyphomycetes with macronematous conidiophores and 1-celled, pigmented conidia. Only two sexual morph records ( $P$. igniaria E.W. Mason \& M.B. Ellis and P. prolific Anastasiou) have been reported so far (Tanaka et al. 2015). Currently there are 187 epithets listed in Index Fungorum (2017).

Periconia cortaderiae Thambugala \& K.D. Hyde, sp. nov.

Fig. 25 
Index Fungorum number: IF553165, Facesoffungi number: FoF 03226

Etymology - Named after the host genus from which it was collected, Cortaderia.

Holotype - MFLU 16-2579

Saprobic on Cortaderia sp. Sexual morph: Undetermined. Asexual morph: Colony effuse, powdery, gregarious, black. Mycelium composed of cottony, branched, hyphae forming dark clusters with conidia scattered on the host surface. Conidiophores 400-800 $\times 4-9.4 \mu \mathrm{m}(\bar{x}=600 \times$ $7 \mu \mathrm{m}, \mathrm{n}=20$ ), macronematous, mononematous, single or rarely 2-3 together on stromata, erect, or bent, thick-walled, brown to dark brown, septate, smooth. Conidiogenous cells $4-4.5(-6) \mu \mathrm{m} \times$ 5.7-9.5 $\mu \mathrm{m}(\bar{x}=4.7 \times 7.2 \mu \mathrm{m}, \mathrm{n}=6)$, monoblastic, discrete on stipe. Conidia 4-6.6 $\times 4.1-7.1$ $\mu \mathrm{m}(\bar{x}=5.2 \times 5.8 \mu \mathrm{m}, \mathrm{n}=65)$, catenate, globose, one-celled, hyaline to pale brown when immature, becoming brown to dark brown, verruculose.

Culture characteristics - Conidia germinating on PDA within $18 \mathrm{~h}$. Colonies growing on PDA, reaching a diameter of $15 \mathrm{~mm}$ after $5 \mathrm{~d}$ at $25^{\circ} \mathrm{C}$, flat, surface smooth, with entire edge, white to grey olivaceous, pale white near the margin, moderately dense, circular; reverse white to greenish olivaceous.

Material examined - THAILAND, Chiang Rai, Mae Fah Luang University, on dead stems and leaves of Cortaderia sp. (Poaceae), 21 December 2014, K.M. Thambugala KM 035 (MFLU 16-2579, holotype); ibid. (GZAAS 16-0123, isotype), ex-type living culture MFLUCC 15-0457, ICMP 21414; ibid., 7 September 2014, K.M. Thambugala KM 023 (MFLU 16-2580, paratype), living culture MFLUCC 15-0451; ibid., 21 December 2014, K.M. Thambugala KM 029 (MFLU 16-2581, paratype), living culture MFLUCC 15-0453, ICMP 21429

Notes - Periconia cortaderiae is described here as a new species and it shares close morphological characters with $P$. byssoides. However, $P$. cortaderiae differs from $P$. byssoides mainly in having smaller conidia (Prasher \& Verma 2015). In the present phylogenetic analysis, $P$. cortaderiae grouped separately from the strains of $P$. byssoides close to $P$. homothallica (Fig. 24), which is the only known sexual morph (Tanaka et al. 2015).

Phaeosphaeriaceae M.E. Barr, Mycologia 71(5): 948 (1979)

Members of the family Phaeosphaeriaceae are commonly found on a large range of species of Poaceae (Quaedvlieg et al. 2013, Phookamsak et al. 2014a). In the present study, we introduce a new genus, 15 new species and three new combinations in the family. Allophaeosphaeria muriformia is re-described with an updated account.

Allophaeosphaeria Ariyawansa et al., in Liu et al., Fungal Diversity 72(1): 137 (2015)

The genus Allophaeosphaeria was described by Liu et al. (2015) and included A. dactylidis and A. muriformia. Allophaeosphaeria clematidis Wanasinghe et al., A. cytisi Wanasinghe et al. and $A$. subcylindrospora Li et al. were subsequently added to the genus (Ariyawansa et al. 2015a, $\mathrm{Li}$ et al. 2016). In the phylogenetic analysis generated in this study, species of Allophaeosphaeria scattered in the family and does not form a well-resolved clade.

Allophaeosphaeria muriformia Ariyawansa, Camporesi \& K.D. Hyde, in Liu et al., Fungal Diversity 72(1): 137 (2015)

Fig. 27

Saprobic on dead stems and leaves of Poaceae. Sexual morph: Ascomata 220- $375 \mu \mathrm{m}$ diameter $\times 180-340 \mu \mathrm{m}$ high $(\bar{x}=300 \times 275 \mu \mathrm{m})$, solitary, scattered, superficial, globose to subglobose, ostiolate. Ostiole papillate, black, smooth, with neck and without periphyses. Peridium 40-70 $\mu \mathrm{m}$ wide, comprising 2-layers, outer layer composed of heavily pigmented thick-walled cells, innermost layer of broad, hyaline compressed rows of cells of textura angularis. Hamathecium comprising 2-3 $\mu \mathrm{m}$ wide, filiform, septate, pseudoparaphyses, embedded in a hyaline gelatinous matrix. Asci (140-)160-250 × 36-46(-52) $\mu \mathrm{m}(\bar{x}=188 \times 44 \mu \mathrm{m}, \mathrm{n}=20)$, 8spored, bitunicate, fissitunicate, elongate cylindrical to slightly clavate, with a minute pedicel, thick-walled and rounded at the apex, with an ocular chamber. Ascospores (37-)40-50 $\times 14-19 \mu \mathrm{m}$ 


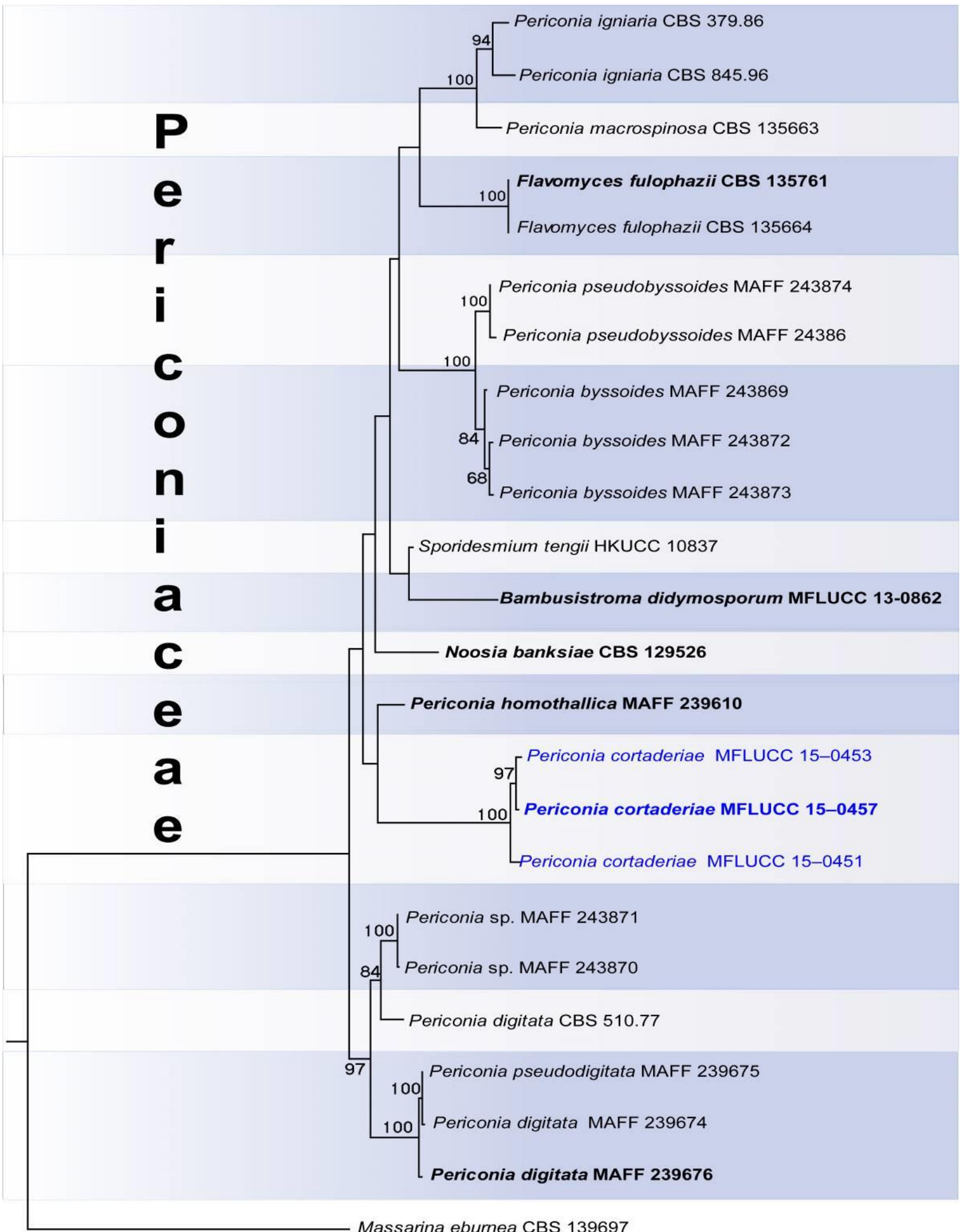

$\longdiv { 0 . 0 2 }$

Fig. 24 - Maximum likelihood tree from analysis of a combined LSU, ITS, and EF1- $\alpha$ dataset of Periconiaceae. Bootstrap support values equal to or greater than $50 \%$ are given above or below the nodes. The ex-type strains are in bold and the new isolates are in blue. The tree is rooted to Massarina eburnea. 


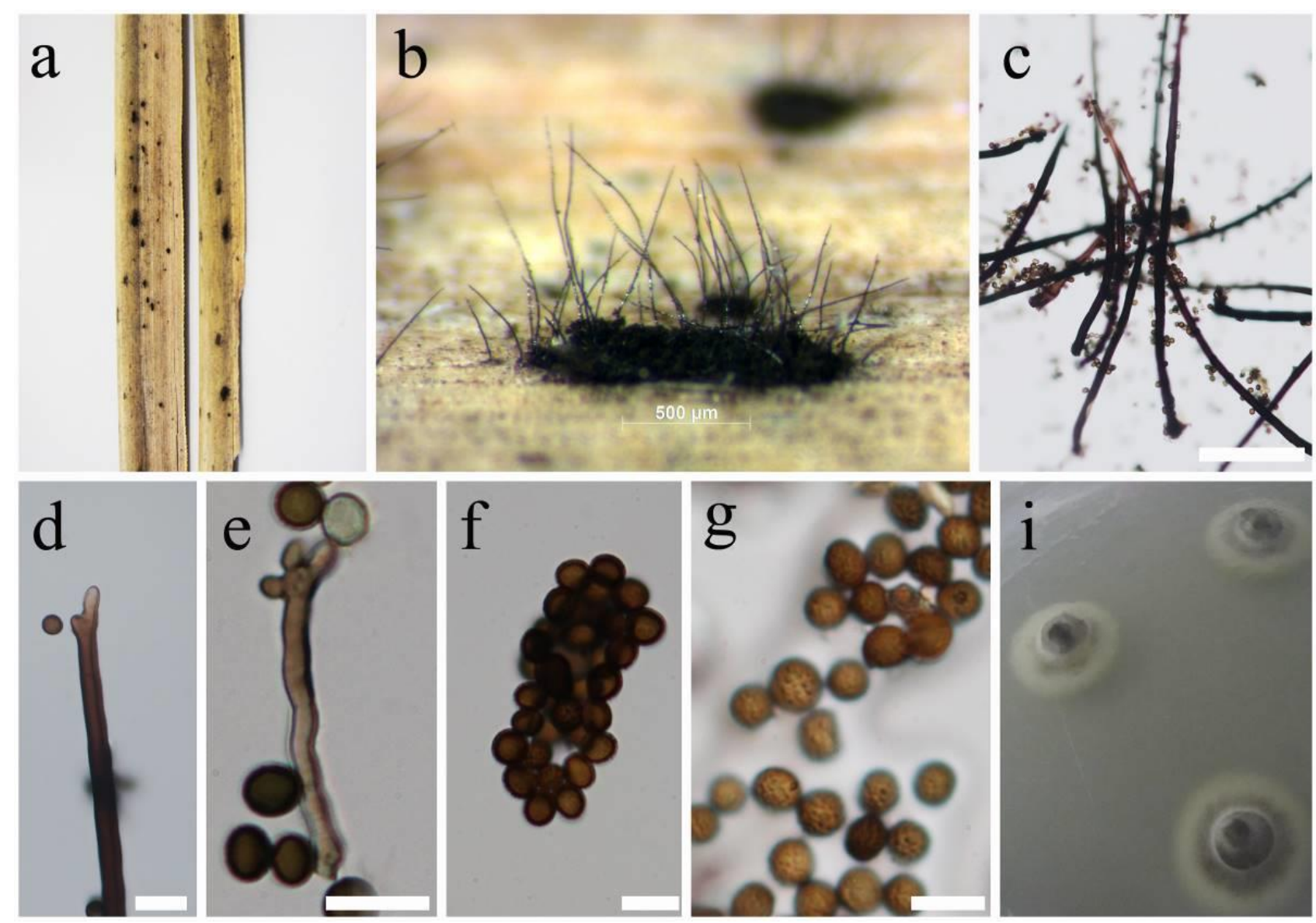

Fig. 25 - Periconia cortaderiae (MFLU 16-2579, holotype). a, b. Colonies on host surface. b-e. Conidiophores. f-g Conidia. i. Colonies on PDA. Scale bars: $\mathrm{c}=100 \mu \mathrm{m}, \mathrm{d}=15 \mu \mathrm{m}, \mathrm{e}-\mathrm{g}=10 \mu \mathrm{m}$.

$(\bar{x}=43 \times 16 \mu \mathrm{m}, \mathrm{n}=30$ ), overlapping $2-3$-seriate, hyaline, oblong to narrowly oblong, straight to slightly curved, 3 -septate or sometimes muriform with 1-2 vertical septa, constricted at each septa, pale brown when mature, smooth-walled, surrounded by a wide mucilaginous sheath. Asexual morph: Undetermined.

Culture characteristics - Ascospores germinating on PDA within $18 \mathrm{~h}$ and germ tubes produced from one or all cells. Colonies on PDA reaching a diameter of $25 \mathrm{~mm}$ after $7 \mathrm{~d}$ at $25{ }^{\circ} \mathrm{C}$, flat, surface smooth to velvety, with entire to slightly undulate edge, olivaceous brown to grey, white near the margin, fairly dense, circular; reverse white to olivaceous-black.

Material examined - ITALY, Province of Forlì-Cesena [FC], Ravaldino in Monte - Forlì, on dead aerial stems and leaves of Lolium sp. (Poaceae), 22 December 2012, Erio Camporesi IT 104 (MFLU 16-2563), living culture MFLUCC 13-0277; ibid., IT 104-2 (MFLU 16-2564).

Notes - Allophaeosphaeria muriformia was introduced by Liu et al. (2015) and is the type species of the genus Allophaeosphaeria. The host of the holotype was not mentioned (Liu et al. 2015). In this study, we re-collected this species on Lolium sp. (Poaceae). We observed pseudoparaphyses, which had not been reported before. Therefore, we re-describe the species and note a slight difference in ascospore dimensions between our collection and those of the holotype. However, in the present phylogenetic analysis (Fig. 26) our strain clustered with the ex-type strain (MFLUCC 13-0349) of A. muriformia. Therefore, we consider the new collection as a new record of the species.

Galiicola Tibpromma, Camporesi \& K.D. Hyde, in Ariyawansa et al., Fungal Diversity: 75(1): 105 (2015)

The genus Galliicola was introduced in the family Phaeosphaeriaceae to accommodate a bitunicate ascomycete saprobic on a Galium species (Ariyawansa et al. 2015a). 


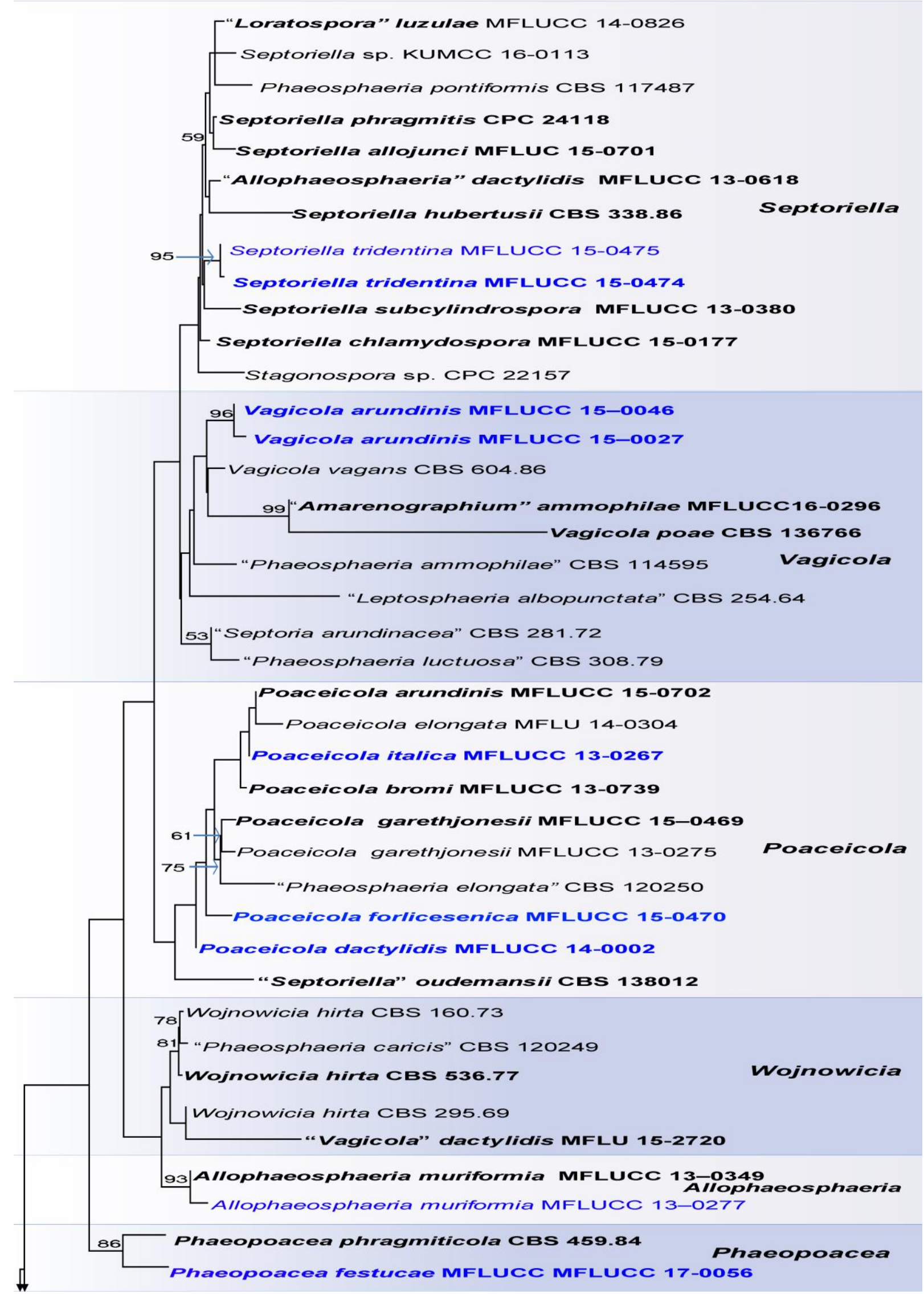

Fig. 26 - Phylogram resulting from maximum likelihood (RAxML) analysis of a combined LSU, SSU, ITS and RPB2 sequence data of 162 strains representing Phaeosphaeriaceae. Maximum likelihood bootstrap values equal to or greater than $50 \%$ are indicated above or below the nodes. The ex-type strains are in bold and the new isolates are in blue. The tree is rooted to Didymella exigua (CBS 183.55). 


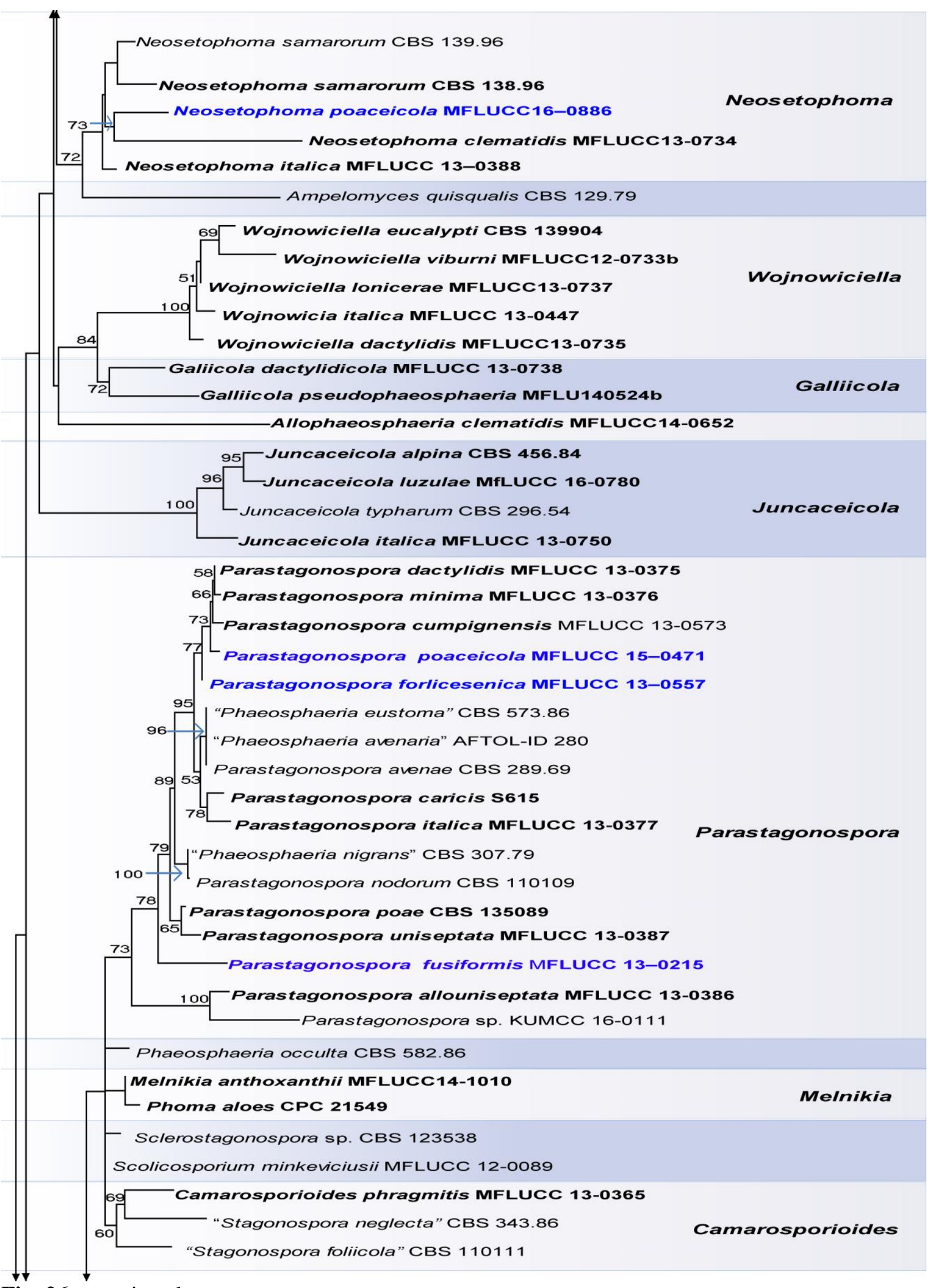

Fig. 26 - continued. 


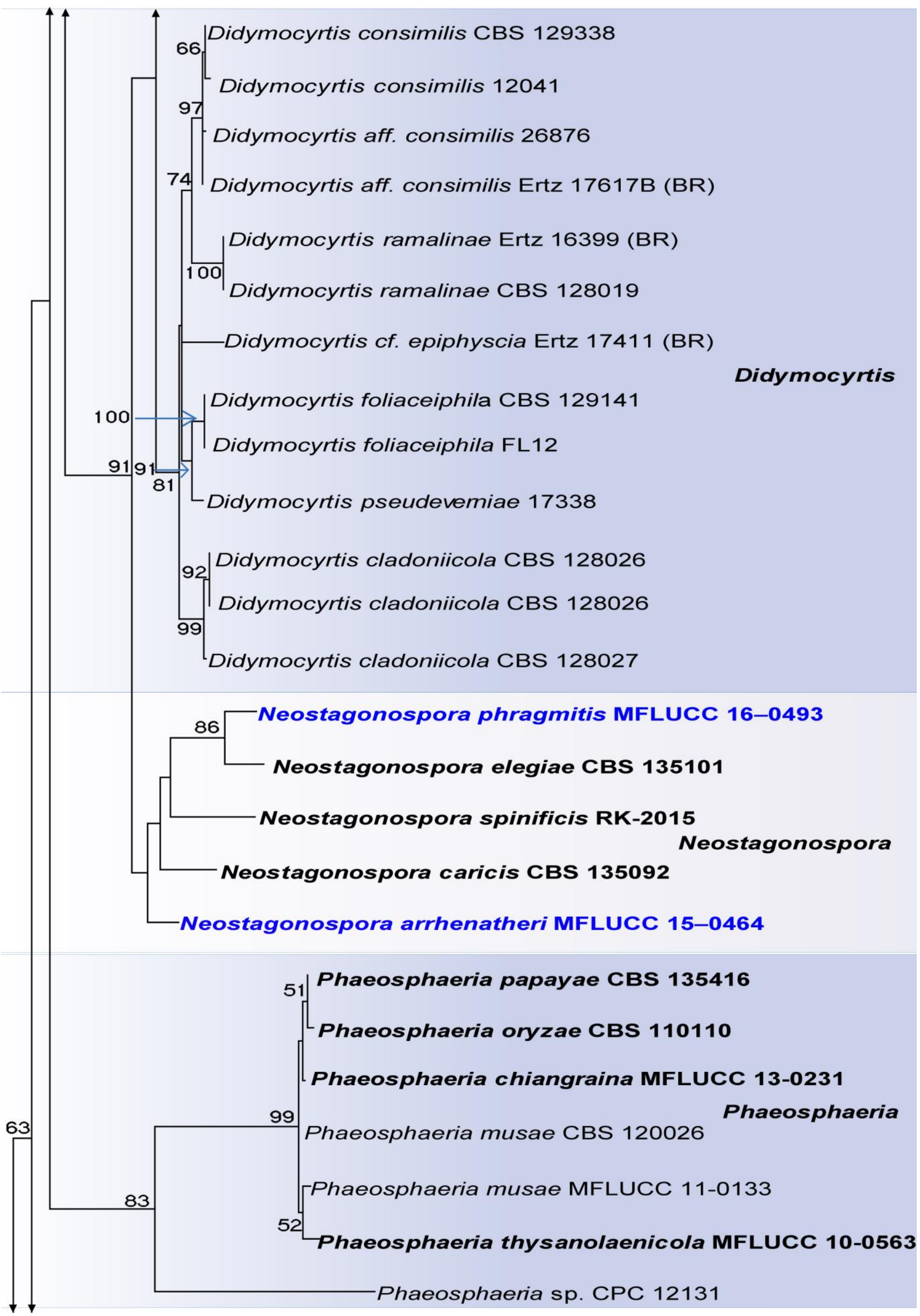

Fig. 26 - continued. 


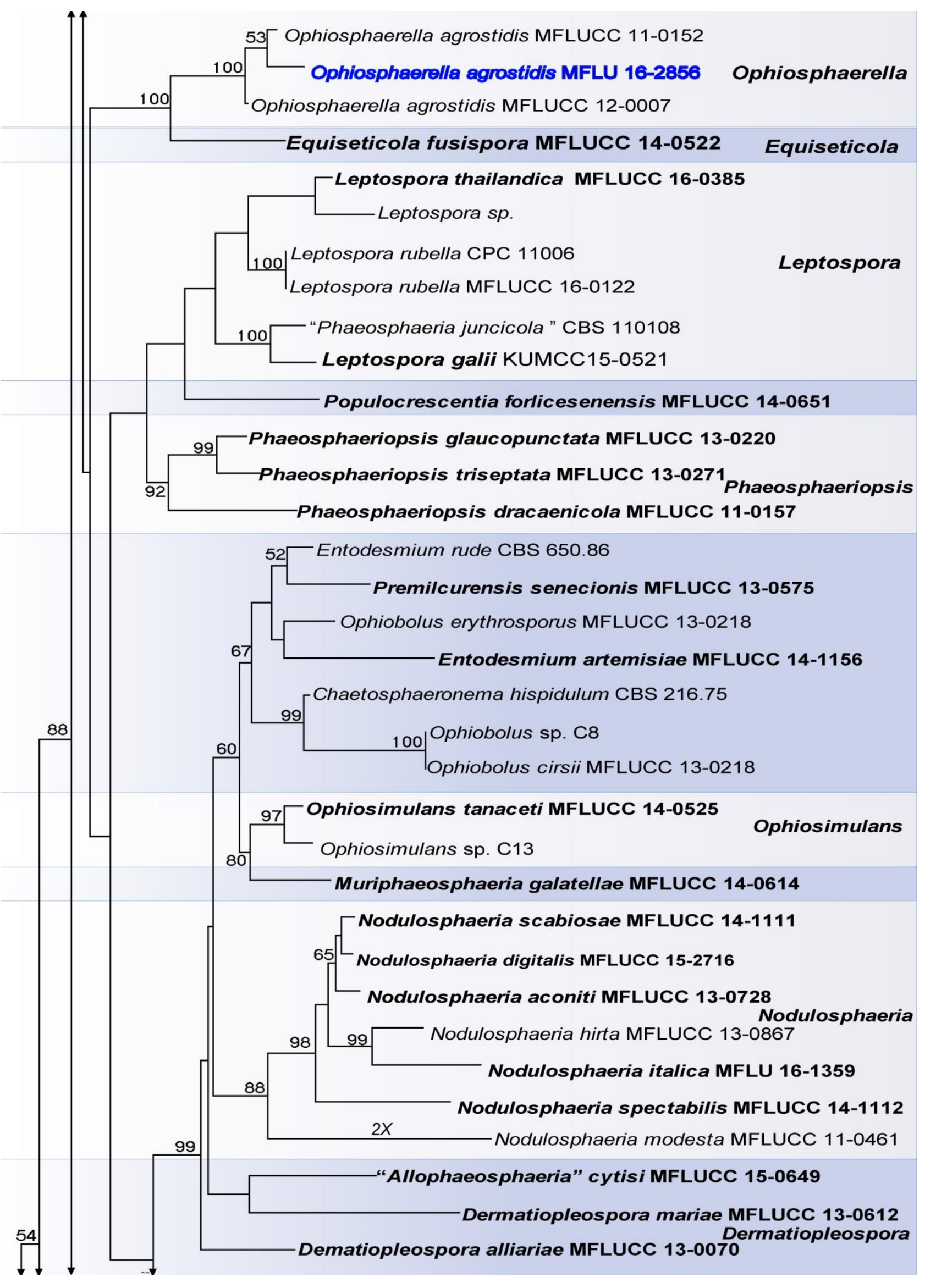

Fig. 26 - continued. 


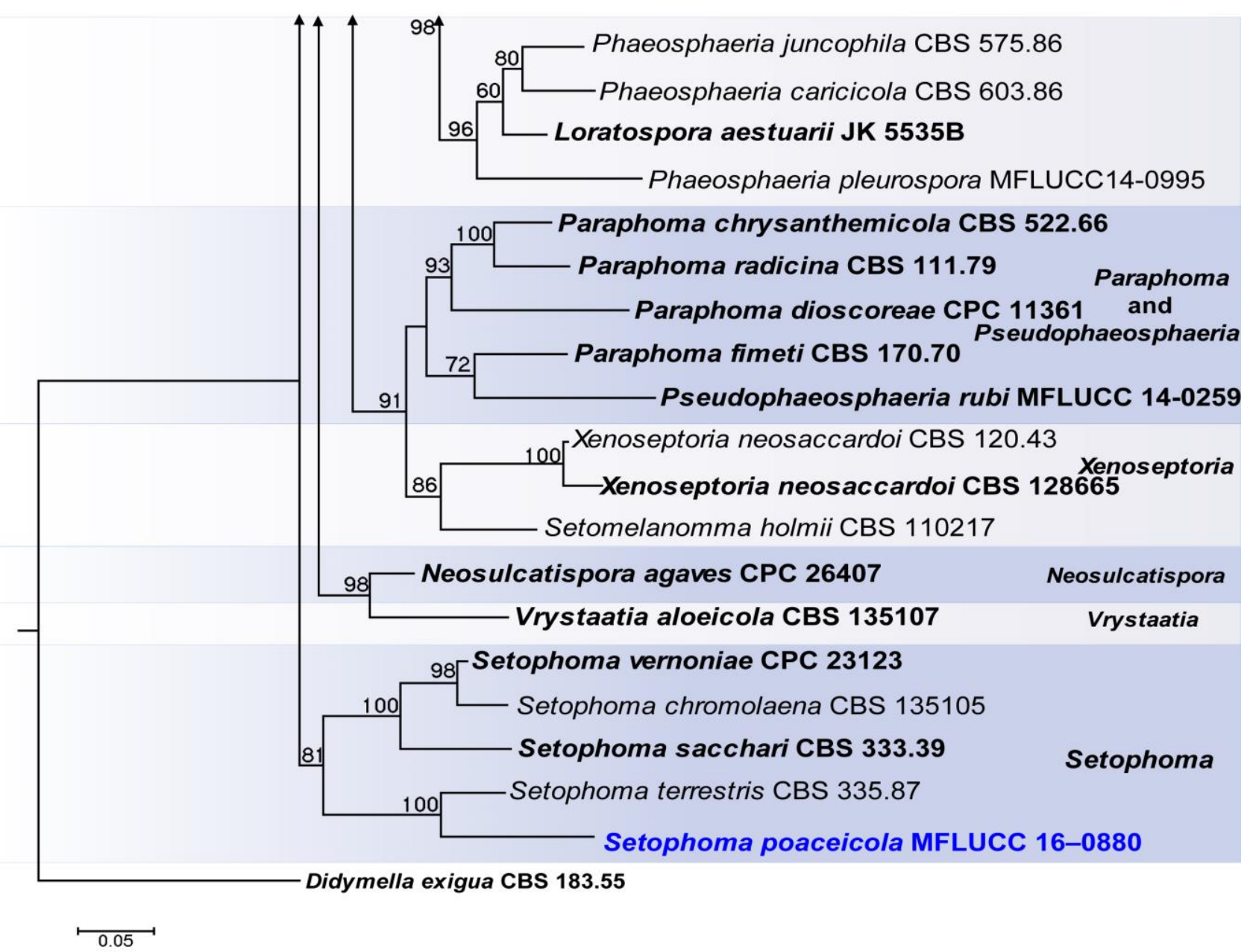

Fig. 26 - continued.

Galiicola dactylidicola (Wijayaw., Camporesi \& K.D. Hyde) Thambugala, \& K.D. Hyde, comb. nov.

Index Fungorum number: IF552973, Facesoffungi number: FoF 03193

Basionym: Wojnowicia dactylidicola Wijayaw., Camporesi \& K.D. Hyde, in Liu et al., Fungal Diversity: 72(1): 142 (2015)

Notes - Wojnowicia dactylidicola was introduced by Liu et al. (2015), however recent phylogenetic studies showed the ex-type strain of $W$. dactylidicola (MFLUCC 13-0738) clustered outside of the genus (Crous et al. 2015). In the present phylogenetic analysis, W. dactylidicola forms a sister clade to Galiicola pseudophaeosphaeria (MFLUCC 14-0524). Unfortunately, no asexual morph has been reported for G. pseudophaeosphaeria (Ariyawansa et al. 2015a). However, we transfer W. dactylidicola to the genus Galiicola based on phylogeny.

Neosetophoma Gruyter, Aveskamp \& Verkley, in de Gruyter, Woudenberg, Aveskamp, Verkley, Groenewald \& Crous, Mycologia 102(5): 1075 (2010)

De Gruyter et al. (2010) erected the genus to accommodate Phoma samararum Desm. and subsequently Liu et al. (2015) added another two new asexual species $N$. clematidis Wijayawardene et al. and N. italica W.J. Li et al.

Neosetophoma poaceicola Goonas., Thambugala \& K.D. Hyde, sp. nov.

Fig. 28

Index Fungorum number: IF552974, Facesoffungi number: FoF 03194

Etymology - in reference to holotype occurring on grasses (Poaceae).

Holotype - MFLU 16-2852 

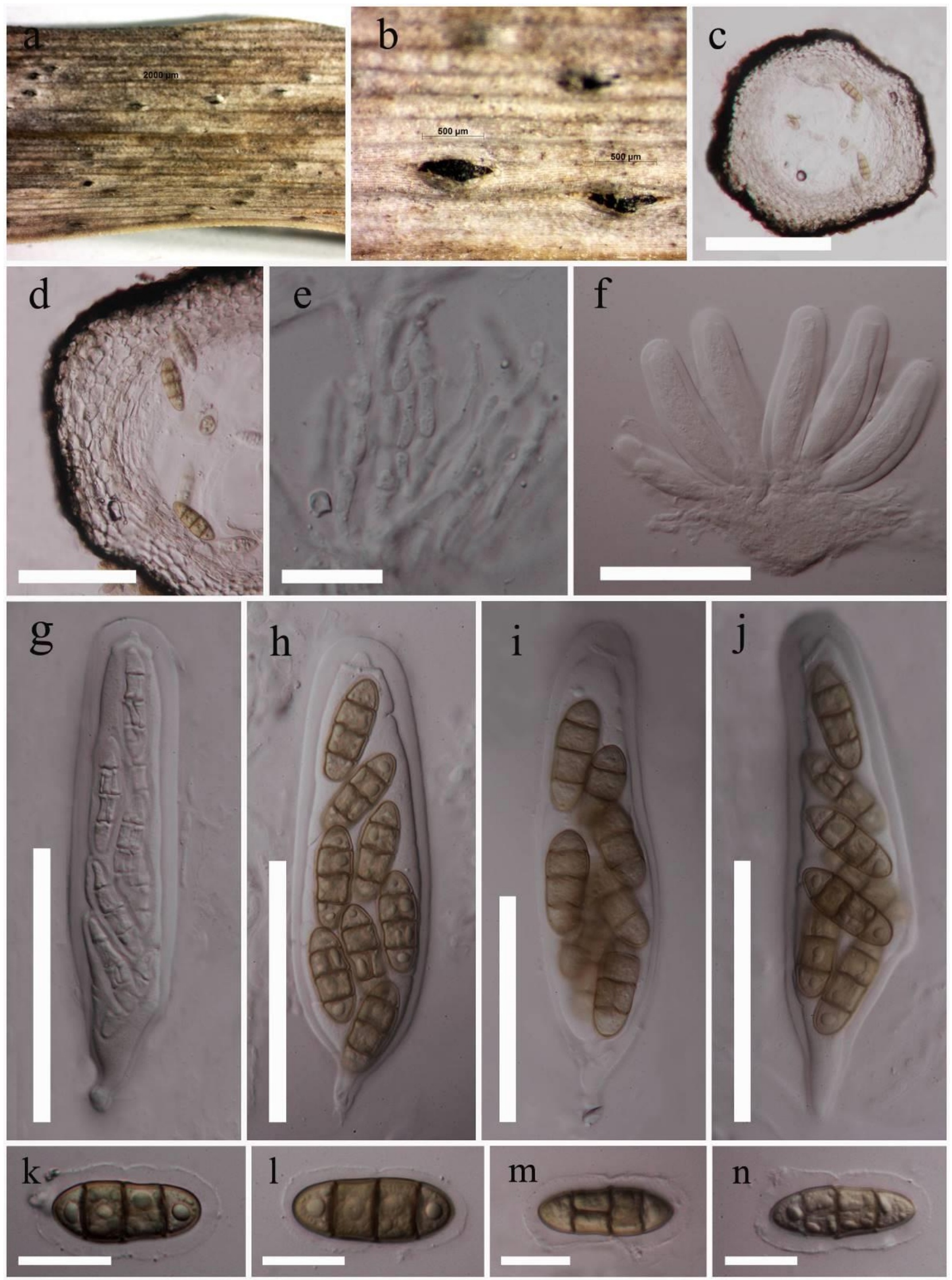

Fig. 27 - Allophaeosphaeria muriformia (MFLU 16-2563). a, b. Appearance of ascomata on host surface. c. Vertical section through ascoma. d. Peridium. e. Pseudoparaphyses. f-g. Immature asci. $\mathrm{h}-\mathrm{j}$. Mature asci. $\mathrm{k}-\mathrm{n}$. Ascospores. Scale bars: $\mathrm{c}=200 \mu \mathrm{m}, \mathrm{d}=100 \mu \mathrm{m}, \mathrm{e}=25 \mu \mathrm{m}, \mathrm{f}-\mathrm{j}=100 \mu \mathrm{m}$, $\mathrm{k}-\mathrm{n}=20 \mu \mathrm{m}$. 
Saprobic on dead grass, as raised, black, shiny globular structures on host surface. Sexual morph: Ascomata 130-145 $\mu \mathrm{m}$ high, 135-160 $\mu \mathrm{m}$ diameter, solitary, gregarious, immersed under epidermis, becoming erumpent through host surface, globose to subglobose glabrous short ostiolate. Peridium 8.5-14.5 $\mu \mathrm{m}$ wide, thick-walled, of equal thickness, composed of several layers of dark brown to brown, pseudoparenchymatous cells of textura angularis. Hamathecium of dense 0.9-1.8 $\mu \mathrm{m}$ wide, filamentous, indistinct, septate, cellular pseudoparaphyses, slightly constricted at the septa, embedded in a hyaline gelatinous matrix. Asci 55-82 $\times 7-9 \mu \mathrm{m}(\bar{x}=70.5 \times 8.4 \mu \mathrm{m}, \mathrm{n}=$ 20), 8-spored, bitunicate, fissitunicate, cylindric-clavate with short rounded pedicel, apically rounded. Ascospores 18.5-22.5 × 3.5-5 $\mu \mathrm{m}(\bar{x}=20.5 \times 4.5 \mu \mathrm{m}, \mathrm{n}=20)$, overlapping 1-2-seriate, hyaline, fusiform, with acute ends, occasionally 1-septate, cell near the septum slightly larger, smooth-walled, guttulate. Asexual morph: Undetermined.

Culture characteristics - Conidia germinating on PDA within $12 \mathrm{~h}$ reaching a diameter of $20 \mathrm{~mm}$ after $7 \mathrm{~d}$ at $25{ }^{\circ} \mathrm{C}$, circular, floccose, flat with even margin, initially pale yellow becoming greenish-grey; reverse yellowish-grey.

Material examined - THAILAND, Chiang Mai Province, Mae Taeng, Mushroom Research Center, on grass litter, 18 March 2016, Ishani D. Goonasekara IGm 22 (MFLU 16-2852, holotype); ibid. (HKAS 97388, isotype), ex-type living culture MFLUCC 16-0886, KUMCC 170023

Notes - Neosetophoma was introduced as an asexual genus and four species have been recorded (Liu et al. 2015, Index Fungorum 2017). In this paper, we introduce a new species and this species represents the first record of the sexual morph of the genus.

Neostagonospora Quaedvl., Verkley \& Crous, Stud. Mycol. 75: 364 (2013)

Neostagonospora was introduced by Quaedvlieg et al. (2013) in Phaeosphaeriaceae to accommodate two new species, $N$. caricis Quaedvlieg et al. and $N$. elegiae Quaedvlieg et al. Subsequently, Yang et al. (2016) included another new species N. spinificis Kirschner et al. Those species were found on Carex acutiformis (Cyperaceae), Elegia cuspidate (Restionaceae) and Spinifex littoreus (Poaceae) (Quaedvlieg et al. 2013, Yang et al. 2016). In the present study, we describe two new species from Italy and Russia on Arrhenatherum elatius (Poaceae) and Phragmites australis (Poaceae).

Neostagonospora arrhenatheri Thambugala, Camporesi \& K.D. Hyde, sp. nov.

Fig. 29

Index Fungorum number: IF552096, Facesoffungi number: FoF 03195

Etymology - Named after the host genus from which it was collected, Arrhenatherum.

Holotype - MFLU 16-2566

Saprobic on dead stem of Arrhenatherum elatius (L.) P.Beauv. ex J.Presl \& C.Presl. Sexual morph: Undetermined. Asexual morph: Conidiomata 100-270 $\mu \mathrm{m}$ diameter $\times 160-270 \mu \mathrm{m}$ high $(\bar{x}=170 \times 210 \mu \mathrm{m}, \mathrm{n}=8$ ), pycnidial, solitary or scattered, erumpent to superficial, black, globose to subglobose, ostiolate. Conidiomatal wall 18-40 $\mu \mathrm{m}$ wide, comprising several layers of thickwalled, black to hyaline, cells of textura angularis. Conidiophores reduced to conidiogenous cells. Conidiogenous cells 4-6.4 $\times 5.2-6.8 \mu \mathrm{m}(\bar{x}=5 \times 6 \mu \mathrm{m}, \mathrm{n}=15)$, lining the conidiomatal cavity, holoblastic, hyaline, ampulliform. Conidia 7.7-12.8 $\times 3-5 \mu \mathrm{m}(\bar{x}=9.4 \times 3.8 \mu \mathrm{m}, \mathrm{n}=60)$, ovoid, with a broadly to narrowly rounded ends, initially hyaline and aseptate, becoming pale brown and 1-septate, slightly constricted septum, smooth-walled.

Culture characteristics - Conidia germinating on PDA within $18 \mathrm{~h}$ and germ tubes produced frequently from the upper cell. Colonies on PDA, reaching a diameter of $38 \mathrm{~mm}$ after $40 \mathrm{~d}$ at $25^{\circ} \mathrm{C}$, circular, flat, surface smooth to velvety, with entire to slightly curled edge, pinkish white, moderately dense, filamentous; reverse pale pink, with white edge.

Material examined - ITALY, Province of Forlì-Cesena [FC], Passo delle Forche - Galeata, on dead aerial stem of Arrhenatherum elatius (L.) P. Beauv. ex J. Presl \& C.Presl (Poaceae), 2 April 2014, Erio Camporesi IT 1794-1 (MFLU 16-2566, holotype); ibid. (GZAAS 16-0116, isotype), ex-type living culture MFLUCC 15-0464, ICMP 21422 

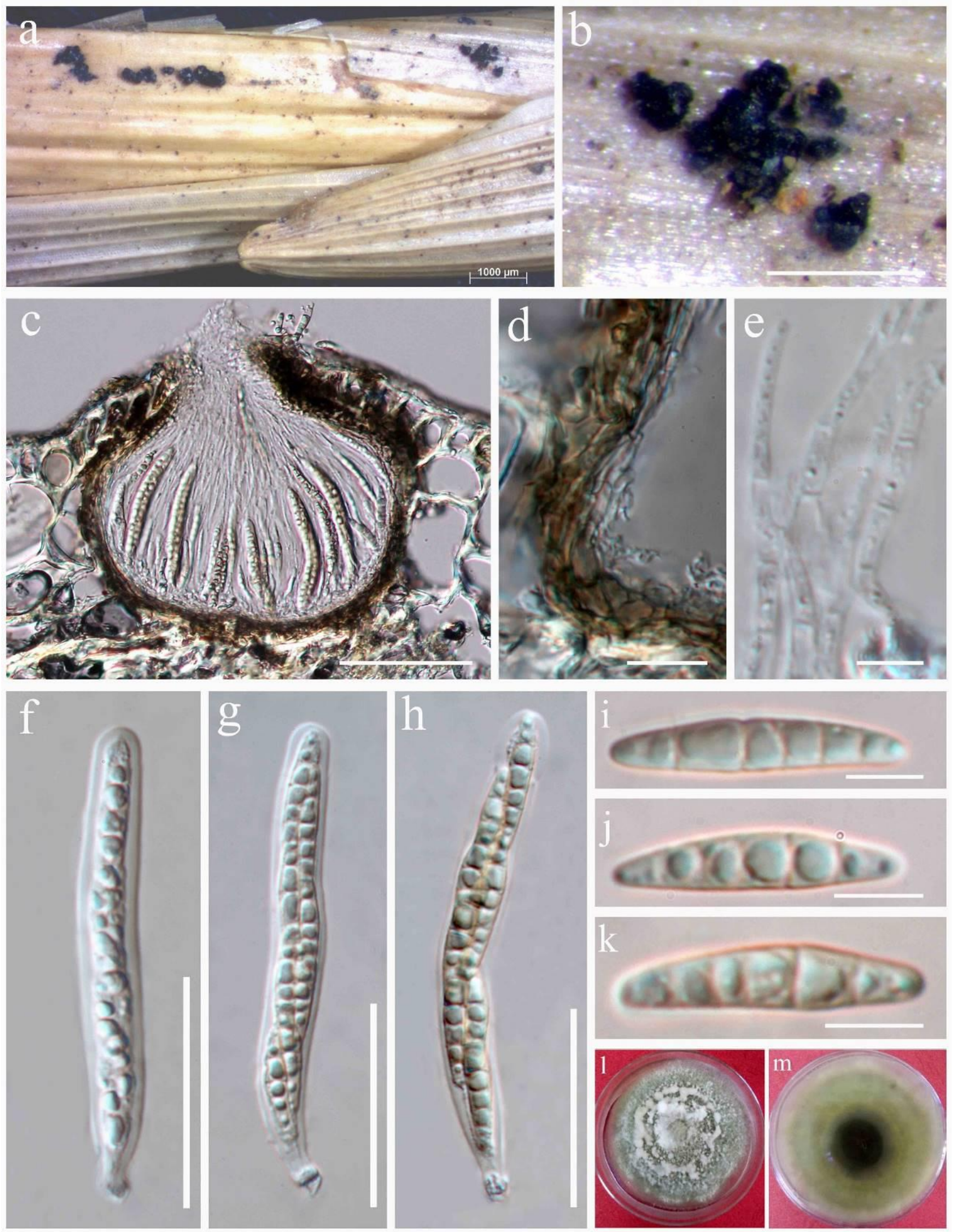

Fig. 28- Neosetophoma poaceicola (MFLU 16-2852, holotype) a. Appearance of ascomata on host. b. Close up of ascoma c. Vertical section through ascoma. d. Peridium. e. Pseudoparaphyses. f-h. Asci. i-k. Ascospores. 1, m. Culture characteristics (from above and reverse). Scale bars: $\mathrm{b}=$ $500 \mu \mathrm{m}, \mathrm{c}=100 \mu \mathrm{m}, \mathrm{d}=20 \mu \mathrm{m}, \mathrm{e}, \mathrm{i}-\mathrm{k}=10 \mu \mathrm{m}, \mathrm{f}-\mathrm{h}=50 \mu \mathrm{m}$. 
Notes - Neostagonospora arrhenatheri differs from other Neostagonospora species that have 1-septate conidia ( $N$. caricis and N. spinificis) in that conidia are ovoid, pigmented and smaller.

Neostagonospora phragmitis Thambugala, Bulgakov \& K.D. Hyde, sp. nov.

Fig. 30

Index Fungorum number: IF552208, Facesoffungi number: FoF 03196

Etymology - Named after the host genus from which it was collected, Phragmites.

Holotype - MFLU 16-2565

Saprobic on stems and leaves of Phragmites australis (Cav.) Trin. ex Steud. Sexual morph: Undetermined. Asexual morph: Conidiomata $120-200 \mu \mathrm{m}$ diameter $\times 100-200 \mu \mathrm{m}$ high $(\bar{x}=155$ $\times 140 \mu \mathrm{m}, \mathrm{n}=6$ ), solitary or scattered in small groups, immersed, slightly erumpent through the host tissue at maturity, black, globose to subglobose, ostiolate. Conidiomatal wall 10-24 $\mu \mathrm{m}$ wide, wider at the apex, comprising few layers of thick-walled, dark brown to lightly pigmented, cells of textura angularis, outer layers somewhat flattened, fusing and indistinguishable from the host tissues. Conidiophores reduced to conidiogenous cells. Conidiogenous cells $2-2.8 \times 2.1-4.7 \mu \mathrm{m}(\bar{x}$ $=2.3 \times 3.4 \mu \mathrm{m}, \mathrm{n}=10$ ), lining the conidiomatal cavity, holoblastic, hyaline, subcylindrical to ampulliform. Conidia $12-15.8 \times 4.3-5.8 \mu \mathrm{m}(\bar{x}=13.6 \times 5.2 \mu \mathrm{m}, \mathrm{n}=40)$, ovoid, with a broadly to narrowly rounded ends, initially hyaline to lightly pigmented and aseptate, becoming pale brown and 3-septate, slightly constricted at septa, smooth-walled.

Culture characteristics - Conidia germinating on PDA within $18 \mathrm{~h}$ and germ tubes produced from one or several cells. Colonies on PDA reaching a diameter of $16 \mathrm{~mm}$ after $7 \mathrm{~d}$ at $25{ }^{\circ} \mathrm{C}$, circular, flat, surface smooth to velvety, with entire edge, white or somewhat pale pink, dense, circular to filamentous; reverse white to pale pink.

Material examined - RUSSIA, Rostov region, Krasnosulinsky District, Donskoye forestry, Gremuchaya Balka (Thunderous gully), on dead stems and leaves of Phragmites australis (Cav.) Trin. ex Steud. (Poaceae), 28 June 2015, Timur Bulgakov T 535 (MFLU 16-2565, holotype); ibid. (GZAAS 16-0115, isotype), ex-type living culture MFLUCC 16-0493, ICMP 21424.

Notes - Neostagonospora phragmitis differs from other Neostagonospora species in its 3septate conidia. This species is also supported phylogenetically in Neostagonospora clade (Fig. 26) with high ML bootstrap value (86\%).

Ophiosphaerella Speg., Anal. Mus. nac. B. Aires, Ser. 3 12: 401 (1909)

Ophiosphaerella was introduced by Spegazzini (1909) and is typified by Op. graminicola. Most species of this genus are found as pathogens or saprobes worldwide on Poaceae and Cyperaceae (Phookamsak et al. 2014a).

Ophiosphaerella agrostidis Dern., M.P.S. Câmara, N.R. O'Neill, Berkum \& M.E. Palm ～Fig. 31 Facesoffungi number: FoF00258

Saprobic on stems of grasses. Sexual morph: See Phookamsak et al. (2014a). Asexual morph: Conidiomata 50-60 $\mu \mathrm{m}$ diameter $65-80 \mu \mathrm{m}$ high $(\bar{x}=58.5 \times 75.5 \mu \mathrm{m}, n=6)$, solitary or scattered, immersed to semi-immersed, appearing as black, slightly raised lesions on host surface, globose to subglobose, ostiolate, papillate. Ostioles 30-33 $\mu \mathrm{m}$ high, $14-18 \mu \mathrm{m}$ diameter $(\bar{x}=31 \times$ $16 \mu \mathrm{m}, n=6$ ). Conidiomatal walls $6.5-11 \mu \mathrm{m}$ wide, comprising several layers of outer, flattened, dark brown cells of textura prismatica and inner, hyaline cells of textura angularis to textura globulosa. Conidiophores reduced to conidiogenous cells. Conidiogenous cells $2-3.5 \times 1.5-3 \mu \mathrm{m}$ $(\bar{x}=3 \times 2.5 \mu \mathrm{m}, n=8)$, lining the conidiomatal cavity, holoblastic, hyaline, doliiform to ampulliform. Conidia 2.5-3.5 $\times 1.2-2 \mu \mathrm{m}(\bar{x}=3 \times 1.5 \mu \mathrm{m}, n=45)$, pale brown, oblong, aseptate, guttulate, smooth-walled.

Culture characteristics - Conidia germinating on PDA within 12 hours reaching a diameter of $18 \mathrm{~mm}$ after 7 days at $25^{\circ} \mathrm{C}$, circular, flat, surface smooth to velvety, with edge entire, grey with a lighter margin; reverse pale yellow. 

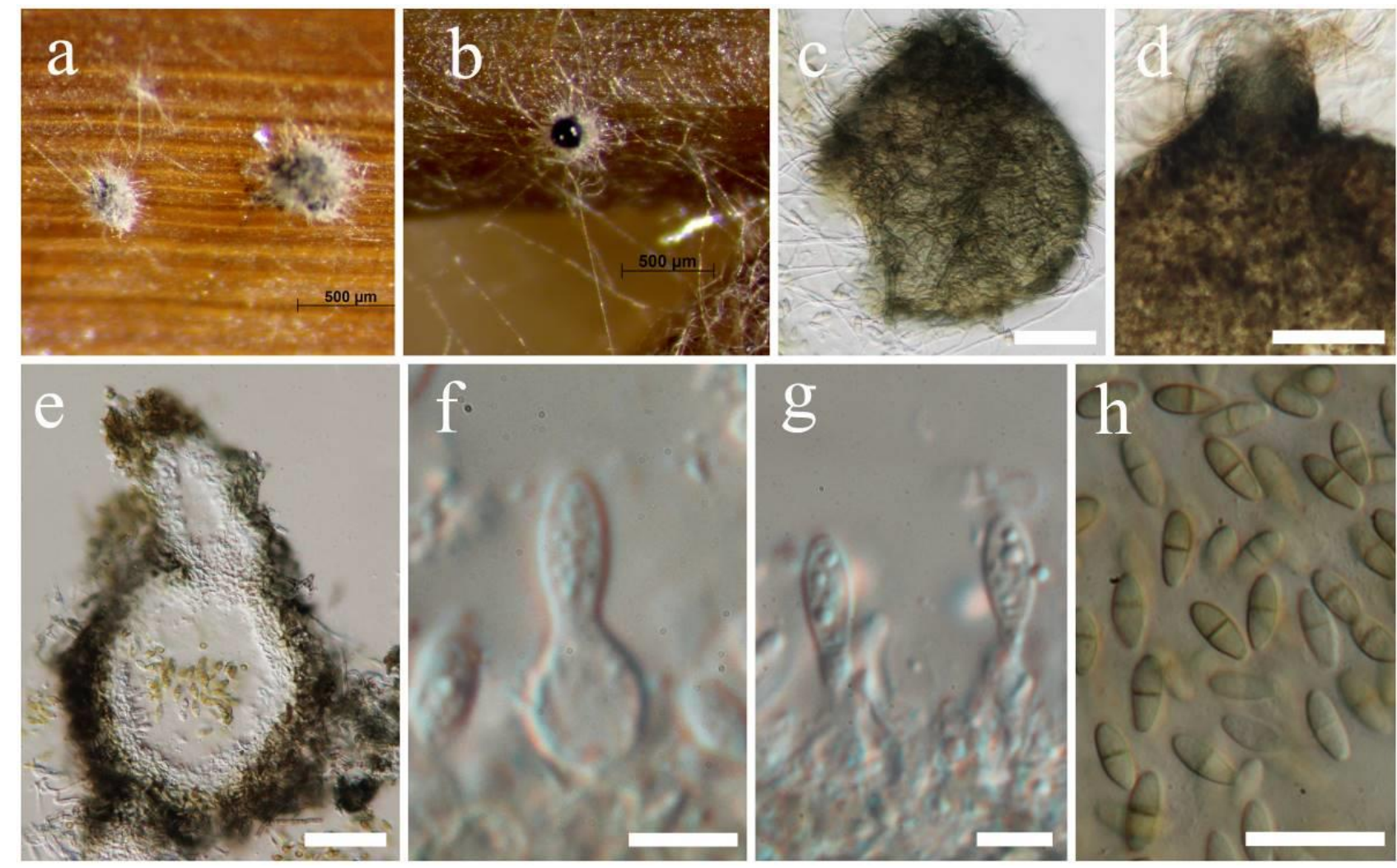

Fig. 29 - Neostagonospora arrhenatheri (MFLU 16-2566, holotype). a, b. Appearance of conidiomata sporulating on Poaceae host in culture. c. Squash mount of conidioma. d. Ostiole. e. Vertical section through conidioma $\mathrm{f}$, g. Developing conidia on conidiogenous cells. $\mathrm{h}$. Mature and immature conidia. Scale bars: $\mathrm{c}-\mathrm{e}=50 \mu \mathrm{m}, \mathrm{f}, \mathrm{g}=5 \mu \mathrm{m}, \mathrm{h}=20 \mu \mathrm{m}$.

Material examined - THAILAND, Chiang Mai Province, Mae Taeng, Mushroom Research Center, on stems of grass (Poaceae), 24 March 2016, Ishani D. Goonasekara IGm 35 (MFLU 162856), living culture MFLUCC 16-0895, KUMCC 17-0027.

Notes - A paraphaeosphaeria-like asexual morph was collected in Thailand on grass litter and the phylogenetic analysis (Fig. 26) shows this strain (MFLUCC 16-0895) to group with two strains of Ophiosphaerella agrostidis (MFLUCC 11-0152 \& MFLUCC 12-0007). Therefore, based on phylogeny we assigned this specimen as the asexual morph of Op. agrostidis and no asexual morph had been reported before for the species. Scolecosporiella species has been recorded as the asexual morph of Op. herpotricha. However, there are no phylogenic evidence to confirm this (Phookamsak et al. 2014a).

Parastagonospora Quaedvl., Verkley \& Crous, Stud. Mycol. 75: 362 (2013)

Parastagonospora was introduced by Quaedvlieg et al. (2013) to accommodate several serious cereal pathogens that were previously placed in either Septoria/Stagonospora, or Leptosphaeria/Phaeosphaeria. The genus is characterized by immersed ascomata with slightly papillate ostiole, bitunicate, shortly stipitate asci, fusoid, subhyaline to pale brown, septate ascospores and coelomycetous asexual morph with hyaline, cylindrical, granular to multi-guttulate, transversely euseptate conidia (Quaedvlieg et al. 2013, Li et al. 2015).

Parastagonospora forlicesenica Chen Y, Camporesi \& K.D. Hyde, sp. nov.

Fig. 32 Index Fungorum number: IF552975, Facesoffungi number: FoF 03197 Etymology - Referring to the province Forlì-Cesena, where the species was encountered. Holotype - MFLU 13-0100 

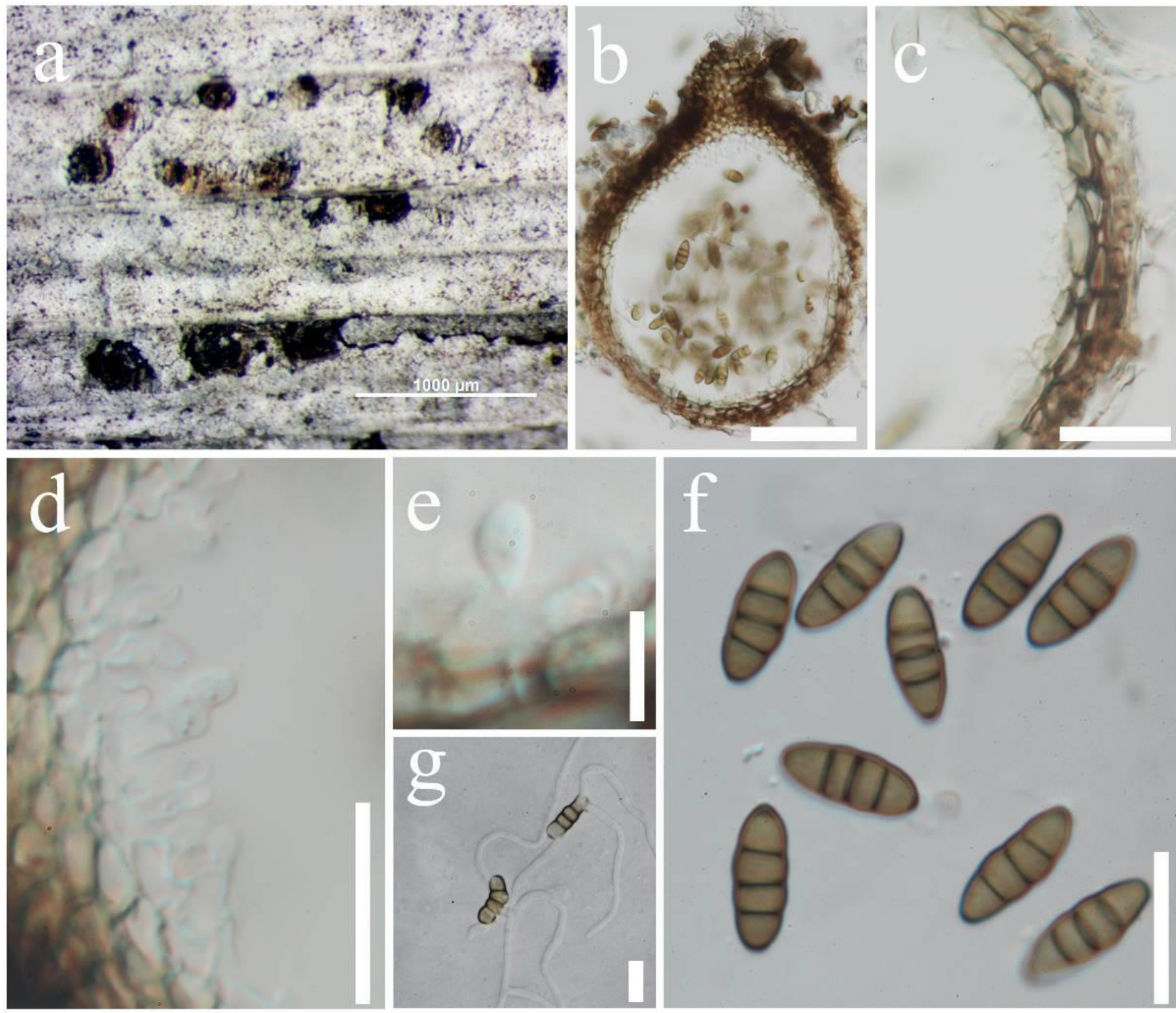

Fig. 30 - Neostagonospora phragmitis (MFLU 16-2565, holotype). a. Appearance of conidiomata on host. b. Vertical section through conidioma. c. Conidiomatal wall. d, e. Developing conidia on conidiogenous cells. f. Mature dark brown conidia. g. Germination conidia. Scale bars: $\mathrm{b}=50 \mu \mathrm{m}$, $\mathrm{c}=20 \mu \mathrm{m}, \mathrm{d}, \mathrm{g}, \mathrm{h}=15 \mu \mathrm{m}, \mathrm{e}=5 \mu \mathrm{m}$.

Saprobic on Dactylis glomerata L. Sexual morph: Ascomata $81-251 \mu \mathrm{m}$ high $\times 100-231 \mu \mathrm{m}$ diameter $(\bar{x}=184 \times 166 \mu \mathrm{m}, \mathrm{n}=10)$, solitary to aggregated, immersed to slightly erumpent, dark brown to black, globose to subglobose, ostiolate. Peridium 10-17 $\mu \mathrm{m}$ wide, composed of several layers of thick-walled, lightly pigmented to dark brown, cells of textura angularis, fusing and indistinguishable from the host tissues. Hamathecium composed 2-2.5 $\mu \mathrm{m}$ wide $(\bar{x}=2.25 \mu \mathrm{m})$, filamentous, branched, septate, cellular pseudoparaphyses situated between and above asci. Asci 57-110 $\times 8-11 \mu \mathrm{m}(\bar{x}=79 \times 9 \mu \mathrm{m}, \mathrm{n}=10), 8$-spored, bitunicate, fissitunicate, cylindric-clavate, short pedicellate, apically rounded with an ocular chamber. Ascospores 20-27 $\times 4-7 \mu \mathrm{m}(\bar{x}=24 \times$ $6 \mu \mathrm{m}, \mathrm{n}=10$ ) overlapping 1-2-seriate, fusiform, slightly curved, 3-septate, constricted at the septa, pale brown, wide in the middle, narrow at both ends, smooth-walled, guttulate. Asexual morph: Undetermined.

Culture characteristics - Ascospores germinating on PDA within 24 h. Colonies growing on PDA, reaching a diameter of $25 \mathrm{~mm}$ after $35 \mathrm{~d}$ at $25^{\circ} \mathrm{C}$, flat, surface smooth to velvety, with entire edge, pinkish white, moderately dense, circular to undulate; reverse reddish to brownish.

Material examined - ITALY, Province of Forlì-Cesena [FC], Monte Fumaiolo, on dead aerial stem of Dactylis glomerata L. (Poaceae), 5 June 2013, Erio Camporesi IT 1281 (MFLU 13- 

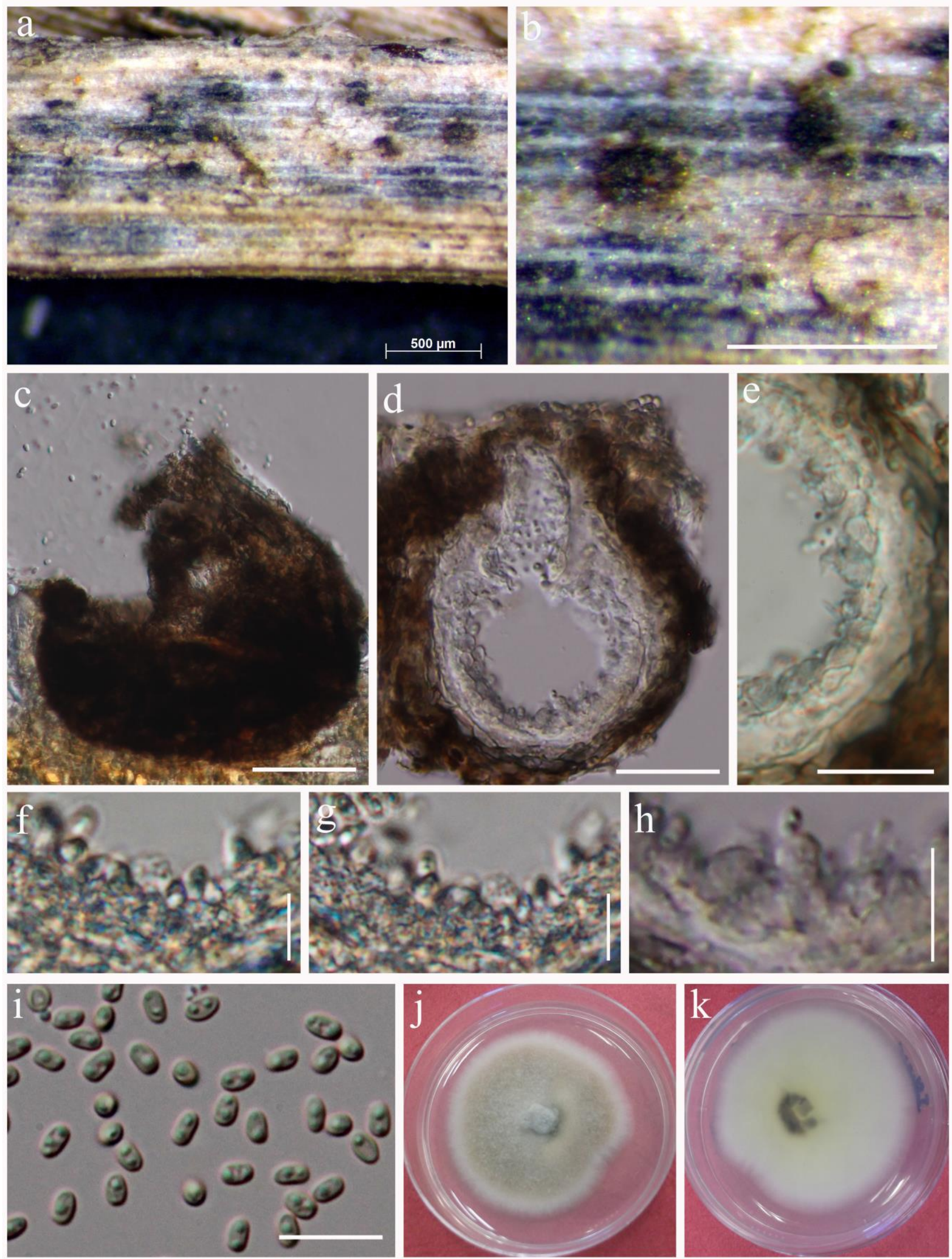

Fig. 31 - Ophiosphaerella agrostidis (MFLU 16-2856, asexual morph). a. Appearance of conidiomata on host surface. b. Close up of conidiomata. c. Squash mount of conidioma d. Section through conidioma. e. Conidiomatal wall. f-h. Conidiogenous cells. i. Conidia. j, k. Colony characteristics (from above and reverse). Scale bars: $b=200 \mu \mathrm{m}, \mathrm{c}-\mathrm{e}=25 \mu \mathrm{m}, \mathrm{f}-\mathrm{h}=5 \mu \mathrm{m}, \mathrm{i}=10$ $\mu \mathrm{m}$. 
0100, holotype); ibid. (GZAAS, isotype), ex-type living culture MFLUCC 13-0557, MFLUCC $15-0461$

Notes - This new species is morphologically similar to $P$. cumpignensis in having immersed ascomata, cylindrical, short pedicellate, asci, fusiform, 3-septate ascospores (Li et al. 2016). However, these two species can be distinguished by the aggregated, smaller ascomata and yellowish ascospores in $P$. forlicesenica.

Parastagonospora fusiformis Thambugala, Camporesi \& K.D. Hyde, sp. nov.

Fig. 33

Index Fungorum number: IF552976, Facesoffungi number: FoF 03198

Etymology - Referring to the fusiform ascospores.

Holotype - MFLU 15-0450

Saprobic on dead stems of Dactylis glomerata L. Sexual morph: Ascomata 200-300 $\mu \mathrm{m}$ diameter $\times 185-290 \mu \mathrm{m}$ high $(\bar{x}=240 \times 222 \mu \mathrm{m}, \mathrm{n}=6)$, solitary to aggregated, immersed, becoming erumpent, visible as slightly raised, black dots on the host surface, uniloculate, globose to subglobose, black, ostiolate. Peridium 15-25(-30) $\mu \mathrm{m}$ wide, composed of 4-5 layers of thinwalled, lightly pigmented to dark brown, cells of textura angularis, fusing and indistinguishable from the host tissues. Hamathecium composed of 2-3 $\mu \mathrm{m}$ wide, filiform, septate, branched cellular pseudoparaphyses situated between and above asci. Asci $(60-) 70-110 \times 14-18 \mu \mathrm{m}(\bar{x}=86 \times 15.6$ $\mu \mathrm{m}, \mathrm{n}=15), 8$-spored, bitunicate, fissitunicate, broadly cylindrical, short pedicellate, apically rounded with indistinct ocular chamber. Ascospores 28-32(-34) $\times 6-8 \mu \mathrm{m}(\bar{x}=30.8 \times 7.2 \mu \mathrm{m}, \mathrm{n}=$ 25 ), overlapping 2-seriate, narrowly fusiform, lightly pigmented to pale brown, 1-septate, constricted at the septum, slightly curved, smooth-walled, with a thin mucilaginous sheath. Asexual morph: Undetermined.

Culture characteristics - Conidia germinating on PDA within 18-24 h and germ tubes produced from one or both ends. Colonies on PDA, reaching a diameter of $50 \mathrm{~mm}$ after $5 \mathrm{~d}$ at $25{ }^{\circ} \mathrm{C}$, circular, flat, surface smooth, with entire edge, white, moderately dense, circular to filamentous; reverse white.

Material examined - ITALY, Province of Forlì-Cesena [FC], Campigna - Santa Sofia, on dead aerial stem of Dactylis glomerata L. (Poaceae), 14 July 2012, Erio Camporesi IT 554 (MFLU 15-0450, holotype); ibid. (GZAAS 16-0135, isotype), ex-type living culture MFLUCC 13-0215.

Notes - Parastagonospora fusiformis differs from all other reported sexual morphs of Parastagonospora mainly in having 1-septate ascospores surrounded by a mucilaginous sheath (Quaedvlieg et al. 2013, Li et al. 2016). The phylogenetic analysis carried out based on combined LSU, SSU, RPB2 and ITS sequences, shows P. fusiformis groups in the Parastagonospora clade in Phaeosphaeriaceae with $78 \%$ bootstrap support (Fig. 26).

Parastagonospora poaceicola Thambugala, Camporesi \& K.D. Hyde, sp. nov.

Fig. 34

Index Fungorum number: IF552977, Facesoffungi number: FoF 03199

Etymology - in reference to holotype occurring on grasses (Poaceae)

Holotype - MFLU 15-2628

Saprobic on dead stems of Dactylis glomerata L. Sexual morph: Ascomata 150-260 $\mu \mathrm{m}$ diameter $\times 120-200 \mu \mathrm{m}$ high $(\bar{x}=200 \times 145 \mu \mathrm{m}, \mathrm{n}=8)$, solitary or aggregated, semi-immersed to erumpent, elongate, uniloculate, subglobose or obpyriform, coriaceous, black, ostiolate. Peridium 20-30 $\mu \mathrm{m}$ wide, composed of 3-5 layers of thin-walled, lightly pigmented to dark brown, somewhat flattened cells of textura angularis. Hamathecium composed of 1.5-2.5 $\mu \mathrm{m}$ wide, cellular, septate, branched, cellular pseudoparaphyses, situated between and above asci. Asci 45-76 $\times 10-14 \mu \mathrm{m}(\bar{x}=61 \times 11.5 \mu \mathrm{m}, \mathrm{n}=15), 8$-spored, bitunicate, fissitunicate, cylindrical, straight or somewhat curved, short pedicellate, apically rounded with an ocular chamber. Ascospores 20-25 $\times$ 4-6 $\mu \mathrm{m}(\bar{x}=22.3 \times 4.6 \mu \mathrm{m}, \mathrm{n}=25)$, overlapping 2-seriate, phragmosporous, narrowly fusiform, lightly pigmented to pale brown, 3-septate, constricted or not at the middle septum, slightly curved, smooth-walled, with a very narrow mucilaginous sheath. Asexual morph: Undetermined. 

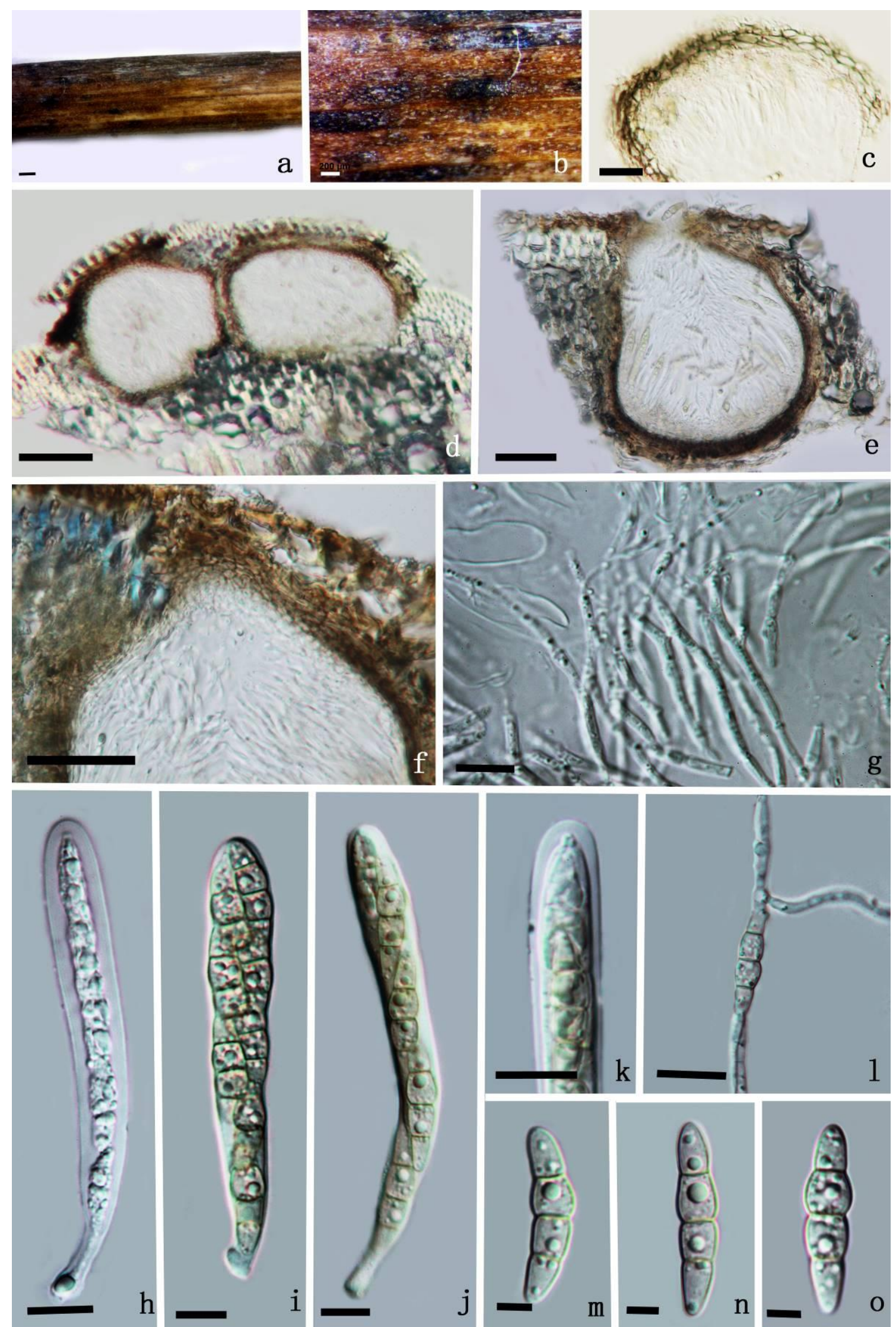

Fig. 32 - Parastagonospora forlicesenica (MFLU 13-0100, holotype). a, b. Appearance of ascomata on the host surface. c. Peridium. d, e. Vertical sections through ascomata. f. Ostiole. g. Pseudoparaphyses. $\mathrm{h}-\mathrm{j}$ Immature and mature asci. k. Apex of ascus. 1. Germinating ascospore. $\mathrm{m}-\mathrm{O}$. Ascospores. Scale bars: $\mathrm{a}=500 \mu \mathrm{m}, \mathrm{b}=200 \mu \mathrm{m}, \mathrm{c}, \mathrm{l}=20 \mu \mathrm{m}, \mathrm{d}-\mathrm{f}=50 \mu \mathrm{m}, \mathrm{g}, \mathrm{h}-\mathrm{k}=10 \mu \mathrm{m}, \mathrm{m}-\mathrm{o}=$ $5 \mu \mathrm{m}$. 
Culture characteristics - Ascospores germinating on PDA within $24 \mathrm{~h}$ and germ tubes produced from one or several cells. Colonies on PDA, reaching a diameter of $32 \mathrm{~mm}$ after $7 \mathrm{~d}$ at $25^{\circ} \mathrm{C}$, circular, flat, surface smooth to velvety, with entire to slightly undulate edge, white, moderately dense, circular; reverse olivaceous to pale brown.

Material examined - ITALY, Province of Forlì-Cesena [FC], near Camposonaldo - Santa Sofia, on dead aerial stem of Dactylis glomerata L. (Poaceae), 6 May 2014, Erio Camporesi IT 1855 (MFLU 15-2628, holotype); ibid. (GZAAS 16-0134, isotype), ex-type living culture MFLUCC 15-0471, ICMP 21415.

Notes - Parastagonospora poaceicola represents a new species that occurs on Dactylis glomerata $\mathrm{L}$. and this species resembles $P$. cumpignensis and $P$. forlicesenica in having 3 -septate ascospores, but $P$. poaceicola has distinct morphological characters such as semi-immersed to erumpent, elongate ascomata and smaller ascospores.

Phaeopoacea Thambugala, Dissanayake \& K.D. Hyde, gen. nov.

Index Fungorum number: IF552978, Facesoffungi number: FoF 03200

Etymology - In reference to a genus in Phaeosphaeriaceae and its Poaceae hosts.

Saprobic on grasses. Sexual morph: Ascomata scattered, immersed, subepidermal, globose, glabrous, ostiolate. Ostiole central, terete, papillate, short, undifferentiated. Peridium composed of 4 layers of brown cells of textura angularis. Hamathecium comprising numerous, thread-like, septate pseudoparaphyses. Asci bitunicate, 8-spored, broadly cylindrical, short pedicellate. Ascospores overlapping 1-2-seriate, narrowly fusiform, straight or slightly curved, 5-septate, first septum slightly constricted, not constricted at other septa, with a vertical septum in the mid cells, third cell from apex enlarged towards base, yellowish-brown, smooth-walled, with a uniform thin sheath (Sexual morph description follows Phaeosphaeria phragmiticola Leuchtm. in Shoemaker \& Babcock 1989). Asexual morph: Conidiomata pycnidial, solitary, or scattered, sometimes in linear rows, immersed, becoming slightly erumpent, dark brown to black, globose to subglobose, ostiolate. Conidiomatal wall comprising few layers of light to dark brown cells of textura angularis, hyaline at conidiogenous region. Conidiophores reduced to conidiogenous cells. Conidiogenous cells hyaline, smooth, holoblastic forming conidia at terminal ends. Conidia pale brown to dark brown, oblong to subcylindrical, with rounded ends, 1-4-septate, guttulate, smoothwalled, with or without mucoid caps at the ends.

Type species - Phaeopoacea festucae Dissanayake, \& K.D. Hyde, sp. nov.

Notes - Phaeopoacea is introduced here as a new genus to accommodate one new species, P. festucae and accommodate Phaeosphaeria phragmiticola (Phaeopoacea phragmiticola). The species occur on grasses and the sexual morph has only been reported for Phaeopoacea phragmiticola. The asexual morph of $P$. festucae and $P$. phragmiticola differs in having 3-4 septate conidia with mucoid caps at the ends. In our phylogenetic analysis, this new genus clearly separates from Septoriella (Fig. 26).

Phaeopoacea festucae Dissanayake, \& K.D. Hyde, sp. nov.

Fig. 35

Index Fungorum number: IF552979, Facesoffungi number: FoF 03201

Etymology - Named after Festuca, the host genus from which it was collected.

Holotype - MFLU 17-0121

Saprobic on Festuca pratensis L. Sexual morph: Undetermined. Asexual morph: Conidiomata 149-252 $\mu \mathrm{m}$ diameter $\times 91-125 \mu \mathrm{m}$ high $(\bar{x}=216 \times 98 \mu \mathrm{m}, \mathrm{n}=5)$, pycnidial, solitary, or scattered, sometimes in linear rows, immersed, becoming slightly erumpent, dark brown to black, globose to subglobose, ostiolate. Conidiomatal wall 15-35 $\mu \mathrm{m}$ wide, comprising few layers of light to dark brown cells of textura angularis, hyaline at conidiogenous region. Conidiophores reduced to conidiogenous cells. Conidiogenous cells $3.4-5.3 \times 3.2-4.4 \mu \mathrm{m}(\bar{x}=$ $4.2 \times 3.9 \mu \mathrm{m}, \mathrm{n}=10$ ), hyaline, smooth, holoblastic forming conidia at terminal ends. Conidia $7.2-$ $9.7 \times 3.5-4.3 \mu \mathrm{m}(\bar{x}=8.1 \times 3.8 \mu \mathrm{m}, \mathrm{n}=30)$, pale brown to dark brown, oblong to sub-cylindrical, with rounded ends, 1-septate, guttulate, smooth-walled. 


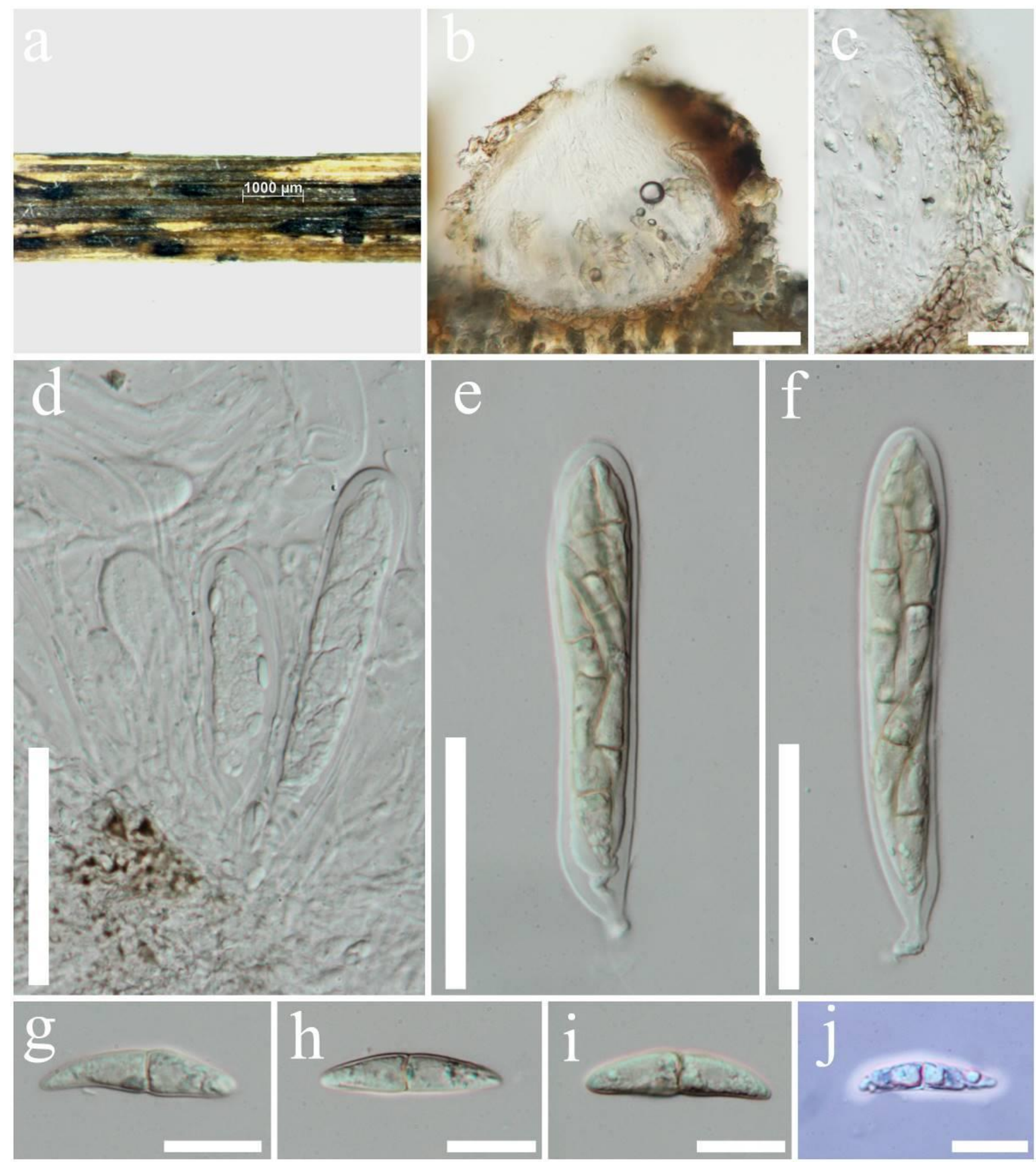

Fig. 33 - Parastagonospora fusiformis (MFLU 15-0450, holotype). a. Appearance of ascomata on the host surface. b. Vertical section through ascoma. c. Peridium. d. Pseudoparaphyses and immature asci. e, f. Mature asci. g-i. Ascospores mounted in water. j. Ascospore stained in Indian ink. Scale bars: $\mathrm{c}, \mathrm{d}-\mathrm{f}=50 \mu \mathrm{m}, \mathrm{c}=25 \mu \mathrm{m}, \mathrm{g}-\mathrm{j}=15 \mu \mathrm{m}$.

Culture characteristics - Conidia germinating on PDA within $18 \mathrm{~h}$ and germ tubes produced frequently from both ends. Colonies on PDA, cover entire plate after $24 \mathrm{~d}$ at $25{ }^{\circ} \mathrm{C}$, olivaceous gray, circular, fluffy, moderately dense, with white edge; reverse pale yellowish gray, with white edge.

Material examined - ITALY, Province of Forlì-Cesena [FC], near Santa Sofia, on dead aerial stem of Festuca pratensis (Poaceae), 16 July 2013, Erio Camporesi IT 1384 (MFLU 170121, holotype); ibid. (GZAAS, isotype), ex-type living culture MFLUCC 17-0056 


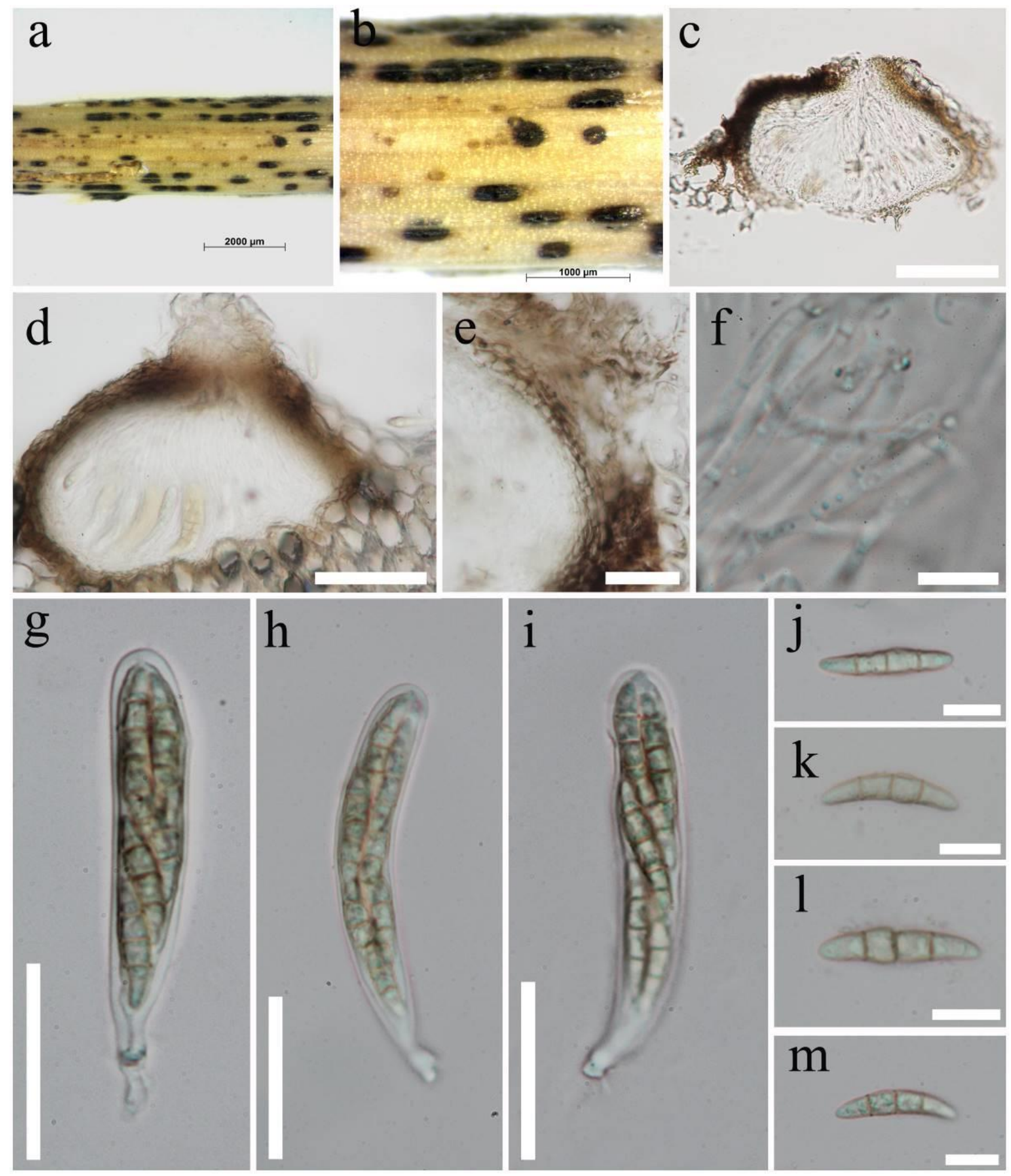

Fig. 34 - Parastagonospora poaceicola (MFLU 15-2628, holotype). a, b. Appearance of ascomata on the host surface. c, d. Vertical section through ascoma. e. Peridium f. Pseudoparaphyses. g-i. Asci. j-m. Ascospores. Scale bars: $c=100 \mu \mathrm{m}, \mathrm{d}=50 \mu \mathrm{m}, \mathrm{e}, \mathrm{g}-\mathrm{i}=30 \mu \mathrm{m}, \mathrm{f}, \mathrm{j}-\mathrm{m}=10 \mu \mathrm{m}$.

Phaeopoacea phragmiticola (Leuchtm) Thambugala \& K.D. Hyde, comb. nov.

Basionym: Phaeosphaeria phragmiticola Leuchtm., Sydowia 37: 138 (1984)

Index Fungorum number: IF552980, Facesoffungi number: FoF 03202

Notes - Phaeosphaeria phragmiticola was introduced by Leuchtmann (1984) and later Crous et al. (2015) transferred it to the genus Septoriella based on phylogeny. However, Li et al. (2015) suggests that this species should be excluded from the genus based on their phylogenetic analysis. In the present phylogenetic analysis, the ex-isotype culture of P. phragmiticola (CBS 459.84) 
grouped as a sister clade to Phaeopoacea festucae. Therefore, we agree with the suggestion by Li et al. (2015) and transfer Phaeosphaeria phragmiticola to the new genus Phaeopoacea.

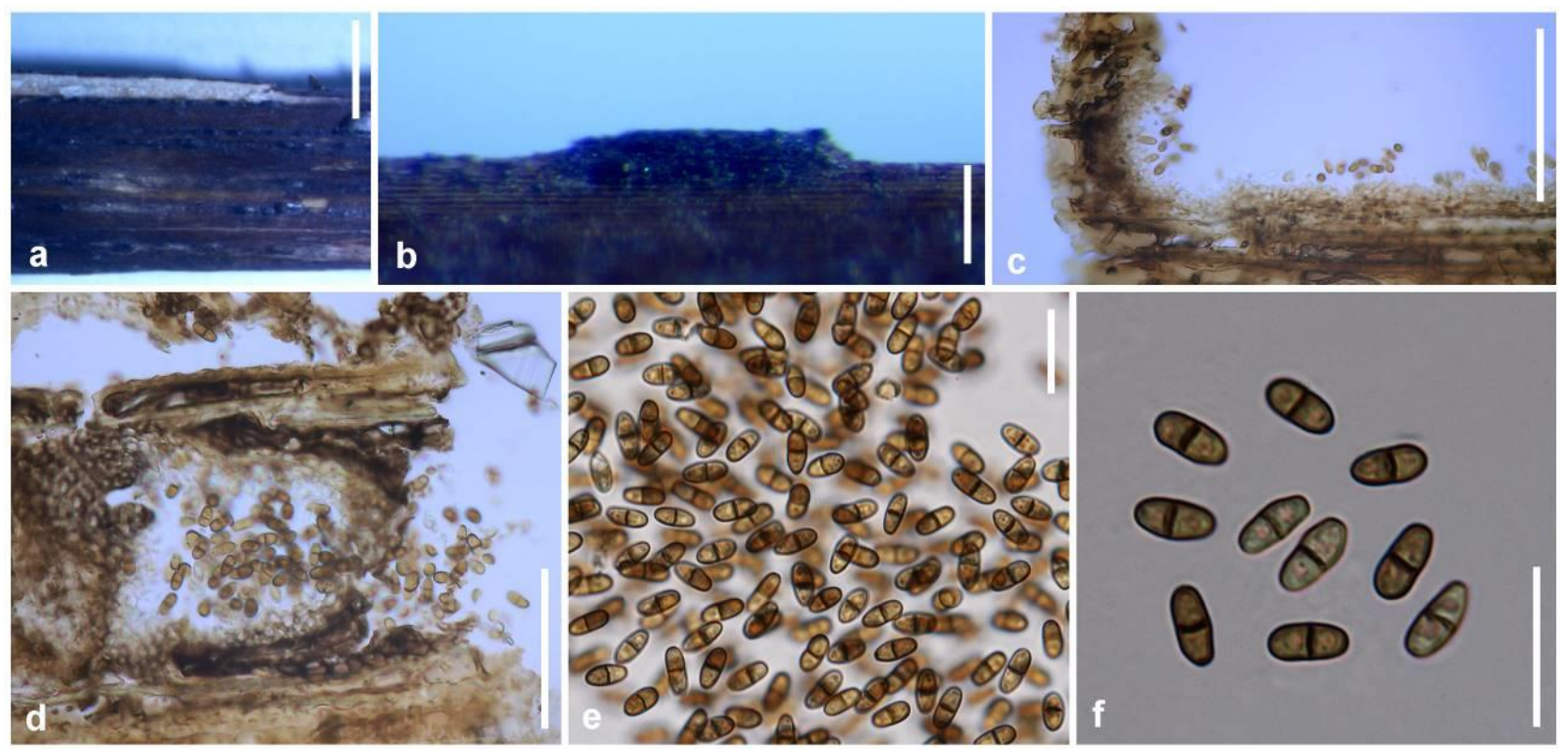

Fig. 35 - Phaeopoacea festucae (MFLU 17-0121, holotype). a, b. Conidiomata on host substrate. c. Peridium. d. Vertical section through conidioma. e, f. One septate brown conidia. Scale bars: b-d $=100 \mu \mathrm{m}, \mathrm{e}, \mathrm{f}=20 \mu \mathrm{m}$.

Poaceicola W.J. Li, Camporesi, D.J. Bhat \& K.D. Hyde, Mycosphere 6 (6): 696 (2015)

The members of this genus are widely distributed on grasses (Poaceae) and currently seven species are recognized in the genus including four new species described here. Li et al. (2015) introduced this genus to accommodate Phaeosphaeria elongata (Wehm.) Shoemaker \& C.E. Babc. and two other new species.

Poaceicola dactylidis Tibpromma, Camporesi \& K.D. Hyde, sp. nov.

Fig. 36

Index Fungorum number: IF552981, Facesoffungi number: FoF 03203

Etymology - Named after Dactylis, the host genus from which it was collected.

Holotype - MFLU 14-0660

Saprobic on Dactylis sp. Sexual morph: Ascomata $129-201 \mu \mathrm{m}$ high $\times 78-172 \mu \mathrm{m}$ diameter $(\bar{x}=162 \times 127 \mu \mathrm{m}, \mathrm{n}=4)$, superficial with base immersed in host tissue, solitary, scattered, black, obpyriform, thick-walled, with a long neck, ostiolate. Peridium 10-45 $\mu \mathrm{m}$ wide, a single layered composed of thick-walled, light brown to dark brown cells of textura angularis. Hamathecium comprising 1-1.6 $\mu \mathrm{m}$ wide, numerous, cellular, branched, septate pseudoparaphyses. Asci 47-54 $\mu \mathrm{m} \times 6-8 \mu \mathrm{m}(\bar{x}=50 \times 7 \mu \mathrm{m}, \mathrm{n}=15), 8$-spored, bitunicate, cylindrical, narrowly rounded at the apex, pedicellate. Ascospores $14-19 \mu \mathrm{m} \times 3-4 \mu \mathrm{m}(\bar{x}=16 \times 3 \mu \mathrm{m}, \mathrm{n}=15)$, fusiform, partially overlapping 1-3-seriate, usually 7-septate, narrowly fusoid with rounded ends, the cells above central septum often broader than the lower ones, yellowish, guttulate, smooth-walled, with a broad mucilaginous sheath. Asexual morph: Undetermined.

Culture characteristics - Ascospores germinating on MEA within $24 \mathrm{~h}$ and producing germ tubes from one or several cells. Colonies growing on MEA, reaching a diameter of $40 \mathrm{~mm}$ after 14 days at $25^{\circ} \mathrm{C}$, flat to slightly raised, surface velvety, with entire edge, iron-grey to white, dense, circular; reverse dark grey to black.

Material examined - ITALY, Province of Trento [TN], Malga di Dimaro - Val di Sole, on dead aerial stem of Dactylis sp. (Poaceae), 14 August 2012, Erio Camporesi IT 701 (MFLU 140660 holotype), ibid. (HKAS94541 isotype), ex-type culture MFLUCC 14-0002, ICMP 
Notes - Poaceicola dactylidis, a new species found on Dactylis sp., is described here. Although it morphologically resembles $P$. forlicesenica, and both species occur on Dactylidis species, $P$. dactylidis has superficial ascomata with a long neck and smaller ascospores (Table 3).

Poaceicola forlicesenica Thambugala, Camporesi \& K.D. Hyde, sp. nov.

Fig. 37

Index Fungorum number: IF552982, Facesoffungi number: FoF 03204

Etymology - Referring to the province Forlì-Cesena, where the species was encountered.

Holotype - MFLU 15-2627

Saprobic on dead stem of Dactylis glomerata L. Sexual morph: Ascomata 200-260 $\mu \mathrm{m}$ diameter $\times 240-300 \mu \mathrm{m}$ high $(\bar{x}=230 \times 270 \mu \mathrm{m}, \mathrm{n}=5)$, immersed, papilla slightly erumpent through the host surface, solitary or aggregated in small groups, scattered, globose to subglobose, coriaceous, dark brown to black, covered by brown, septate hyphae, ostiolate. Ostiole central, papillate, ostiolar canal filled with hyaline to lightly pigmented cells. Peridium 20-35 $\mu \mathrm{m}$ wide, wider at the apex, comprising few layers of thick-walled, dark brown to lightly pigmented cells of textura angularis, inner layers' hyaline, somewhat flattened cells. Hamathecium comprising 1-2 $\mu \mathrm{m}$ wide, cellular, aseptate, guttulate, pseudoparaphyses extending above asci. Asci $90-115 \times 12-$ $14 \mu \mathrm{m}(\bar{x}=104 \times 13 \mu \mathrm{m}, \mathrm{n}=20), 8$-spored, bitunicate, fissitunicate, cylindrical to cylindricclavate, strait or slightly curved, short pedicellate, apically rounded, with an ocular chamber. Ascospores $26-31 \times 4.2-5.4 \mu \mathrm{m}(\bar{x}=28.2 \times 4.7 \mu \mathrm{m}, \mathrm{n}=30)$, overlapping 1-2-seriate, pale yellowish brown, cylindric-fusiform, (6-)7-septate, tapering towards the rounded ends, slightly enlarged at the third cell from the apex, straight to slightly curved, slightly constricted at the septa, guttulate, smooth-walled, with a mucilaginous sheath. Asexual morph: Undetermined.

Culture characteristics - Ascospores germinating on PDA within $24 \mathrm{~h}$ and producing germ tubes from one or several cells. Colonies growing on PDA, reaching a diameter of $42 \mathrm{~mm}$ after $7 \mathrm{~d}$ at $25{ }^{\circ} \mathrm{C}$, flat to pulvinate, surface velvety, with entire edge, white to iron-grey, dense, circular; reverse olivaceous brown to black.

Material examined - ITALY, Province of Forlì-Cesena [FC], San Paolo in Alpe - Santa Sofia, on dead aerial stem of Dactylis glomerata L. (Poaceae), 3 May 2014, Erio Camporesi IT 1852 (MFLU 15-2627, holotype); ibid. (GAAS 16-0133, isotype), ex-type living culture MFLUCC 15-0470, ICMP 21411

Notes -Molecular analysis and morphological features indicate that the new species belongs to Poaceicola (Fig. 26, table 3). Although, P. forlicesenica has similar number of septa with $P$. dactylidis, ascospore sizes are significantly different (table 3 ). Ascomata of $P$. forlicesenica are immersed, while ascomata of $P$. dactylidis are nearly superficial.

Poaceicola garethjonesii Thambugala, Camporesi \& K.D. Hyde, sp. nov.

Fig. 38

Index Fungorum number: IF552983, Facesoffungi number: FoF 03205

Etymology - In honour of E.B. Gareth Jones, a great mycologist, recognizing his invaluable contribution to mycology.

Holotype - MFLU 15-2626

Saprobic on dead stem of Dactylis glomerata L. Sexual morph: Ascomata 200-270 $\mu \mathrm{m}$ diameter $\times 175-300 \mu \mathrm{m}$ high $(\bar{x}=244 \times 255 \mu \mathrm{m}, \mathrm{n}=6)$, immersed, papilla slightly erumpent through the host surface, solitary or aggregated in small groups, scattered, globose to subglobose, coriaceous, dark brown to black, covered by dark brown, vegetative hyphae, ostiolate. Ostiole central, papillate, ostiolar canal filled with hyaline cells. Peridium $12-25 \mu \mathrm{m}$ wide, wider at the apex, comprising few layers of thick-walled, dark brown to lightly pigmented cells of textura angularis, outer layers fusing and indistinguishable from the host tissues. Hamathecium comprising 2-3 $\mu \mathrm{m}$ wide, cellular, guttulate, pseudoparaphyses extending above asci. Asci $95-122 \times 10-12 \mu \mathrm{m}$ $(\bar{x}=110 \times 11 \mu \mathrm{m}, \mathrm{n}=21), 8$-spored, bitunicate, fissitunicate, cylindrical to cylindric-clavate, strait 


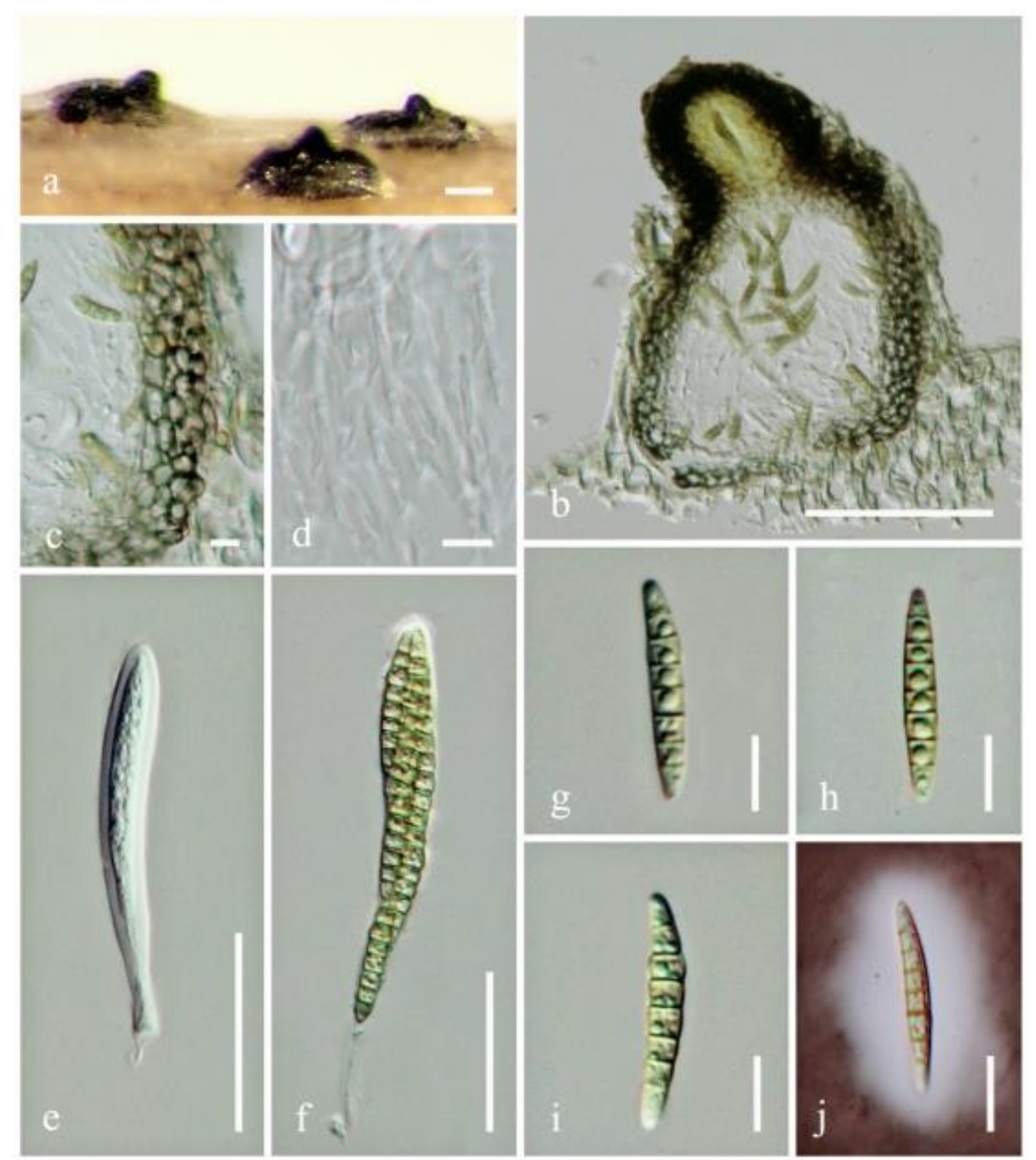

Fig. 36 - Poaceicola dactylidis (MFLU 14-0660, holotype). a. Appearance of ascomata on host surface. b. Vertical section through ascoma. c. Section of peridium. d. Pseudoparaphyses. e-f. Asci. $\mathrm{g}-\mathrm{j}$. Ascospores. Scale bars: $\mathrm{a}=100 \mu \mathrm{m}, \mathrm{b}=50 \mu \mathrm{m}, \mathrm{c}, \mathrm{e}-\mathrm{f}=20 \mu \mathrm{m}, \mathrm{d}, \mathrm{g}-\mathrm{j}=5 \mu \mathrm{m}$.

or slightly curved, short pedicellate, apically rounded, with an ocular chamber. Ascospores 27-32 $\times$ 4-4.8 $\mu \mathrm{m}(\bar{x}=30 \times 4.5 \mu \mathrm{m}, \mathrm{n}=35)$, overlapping 1-2-seriate, yellowish brown, cylindric-fusiform, (7-)8(-9)-septate, tapering towards the rounded ends, slightly enlarged at the third cell from the apex, straight to slightly curved, slightly constricted at the septa, guttulate, smooth-walled, with a mucilaginous sheath. Asexual morph: Undetermined.

Culture characteristics - Ascospores germinating on PDA within $24 \mathrm{~h}$ and producing germ tubes from several cells. Colonies growing slowly on PDA, reaching a diameter of $54 \mathrm{~mm}$ after 14 $\mathrm{d}$ at $25{ }^{\circ} \mathrm{C}$, flat, surface smooth to velvety, with entire edge, iron-grey to white, dense, circular; reverse brown or olivaceous to black.

Material examined - ITALY, Province of Forlì-Cesena [FC], near San Paolo in Alpe - Santa Sofia, on dead aerial stem of Dactylis glomerata L. (Poaceae), 3 May 2014, Erio Camporesi IT 1850-2 (MFLU 15-2626, holotype); ibid. (GZAAS 16-0136, isotype), ex-type living culture 
MFLUCC 15-0469, ICMP 21408; ibid., Passo delle Forche - Galeata, dead leaves of Dactylis glomerata L. (Poaceae), 18 November 2012, Erio Camporesi IT 910 (MFLU 16-2604, paratype), ex-paratype living culture MFLUCC 13-0275
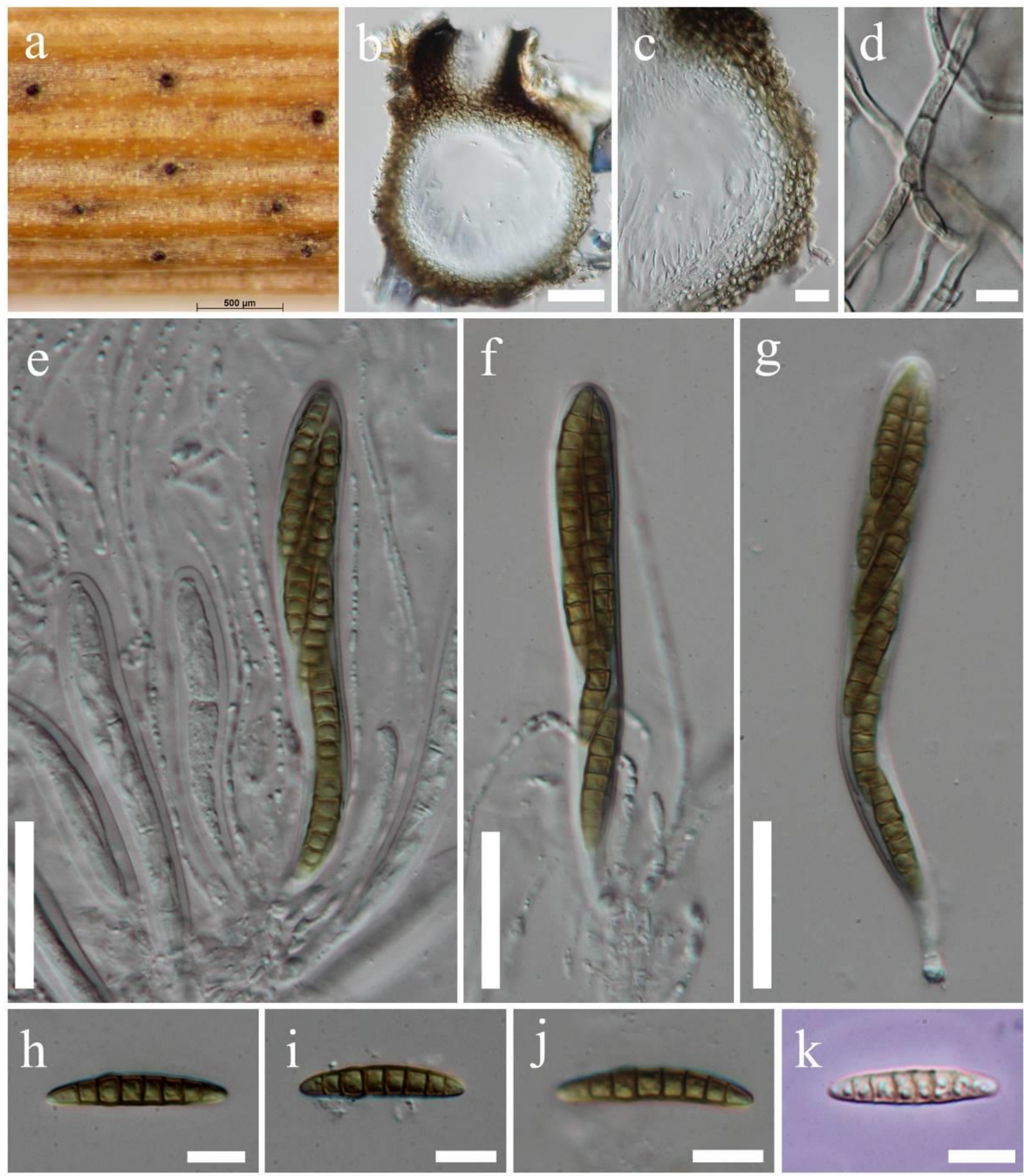

Fig. 37 - Poaceicola forlicesenica (MFLU 15-2627, holotype). a. Appearance of ascomata on the host surface. b. Vertical section through ascomata. c. Peridium d. Brown, septate vegetative hyphae. e-g. Asci. h-k. Ascospores. Scale bars: b, e-g $=50 \mu \mathrm{m}, \mathrm{c}=20 \mu \mathrm{m}, \mathrm{d}, \mathrm{h}-\mathrm{k}=10 \mu \mathrm{m}$.

Notes - Poaceicola garethjonesii is morphologically similar to Poaceicola arundinis W.J. Li et al., but it differs in having immersed ascomata with a thinner peridium and mucilaginous sheath (Hyde et al. 2016). In our phylogenetic analysis (Fig. 26), P. garethjonesii forms a sister clade to "Phaeosphaeria elongata" (CBS 120250) with moderate support (75\% ML). 
Poaceicola italica Thambugala, Camporesi \& K.D. Hyde, sp. nov.

Index Fungorum number: IF552984, Facesoffungi number: FoF 03206

Etymology - Named after the country (Italy), where the holotype was collected.

Holotype - MFLU 15-0547

Saprobic on dead stem of Arundo pliniana Turra. Sexual morph: Ascomata (150-)200-300 $\mu \mathrm{m}$ diameter $\times 280-420 \mu \mathrm{m}$ high $(\bar{x}=225 \times 345 \mu \mathrm{m}, \mathrm{n}=8)$, immersed, slightly erumpent at maturity, solitary or aggregated in small groups, scattered, subglobose, coriaceous, dark brown to black, covered by dark brown, septate vegetative hyphae, with long necks, ostiolate. Peridium 10 $35 \mu \mathrm{m}$ wide, wider at the apex, comprising few layers of thick-walled, dark brown to lightly pigmented cells of textura angularis, outer layers fusing and indistinguishable from the host tissues. Hamathecium comprising 2-3 $\mu \mathrm{m}$ wide, cellular, septate pseudoparaphyses with guttules. Asci $95-150 \times 14-18 \mu \mathrm{m}(\bar{x}=118 \times 16 \mu \mathrm{m}, \mathrm{n}=15), 8$-spored, bitunicate, fissitunicate, cylindrical to cylindric-clavate, strait or slightly curved, short pedicellate, apically rounded, with an ocular chamber. Ascospores 35-42.5 $\times$ 4.7-6.5 $\mu \mathrm{m}(\bar{x}=38.5 \times 5.7 \mu \mathrm{m}, \mathrm{n}=25)$, overlapping 1-3-seriate, pale yellowish-brown, cylindric-fusiform, 10-11-septate, tapering towards the rounded ends, enlarged at the third cell from the apex, straight to slightly curved, slightly constricted at the septa, guttulate, smooth-walled, surrounded by a thick mucilaginous sheath. Asexual morph: Undetermined.

Culture characteristics - Ascospores germinating on PDA within $24 \mathrm{~h}$ and producing germ tubes from several cells. Colonies growing on PDA, reaching a diameter of $40 \mathrm{~mm}$ after $7 \mathrm{~d}$ at $25{ }^{\circ} \mathrm{C}$, flat to slightly raised, surface smooth to velvety, with entire edge, white to grey olivaceous, dense, circular; reverse olivaceous to pale brown.

Material examined - ITALY, Province of Forlì-Cesena [FC], Strada San Zeno - Galeata, dead aerial stem of Arundo plinii Turra. (Poaceae), 26 November 2012, Erio Camporesi IT 931 (MFLU 15-0547, holotype); ibid. (GZAAS 16-0130, isotype), ex-type living culture MFLUCC 13-0267, ICMP 21567.

Notes - Poaceicola italica is introduced here as a new species and it differs from all other Poaceicola species in having 10-11-septate ascospores (Table 3).

Septoriella Oudem., Ned. kruidk. Archf, 2 sér. 5: 52 (repr.) (1889)

Septoriella is an asexual genus that is commonly distributed on grasses. The genus is characterized by pycnidial, unilocular conidiomata and fusiform to subcylindrical, euseptate, pale brown, conidia bearing mucoid appendages at both ends (Crous et al. 2015, Li et al. 2015). Crous et al. (2015) reduced to synonymy Wojnowicia with Septoriella, but we recognized Wojnowicia as a separate genus (Fig. 26)

Septoriella chlamydospora (Jayasiri, Camporesi \& K.D. Hyde) Thambugala, \& K.D. Hyde, comb. nov.

Index Fungorum number: IF552990, Facesoffungi number: FoF 03209

Basionym: Vagicola chlamydospora Jayasiri, Camporesi \& K.D. Hyde, in Jayasiri et al. 6(6): 718 (2015)

Notes - Vagicola chlamydospora was introduced by Jayasiri et al. (2015b), based on phylogenetic analysis of a combined LSU and ITS sequence dataset. However, in our phylogenetic analysis of a combined LSU, SSU, ITS and RPB2 sequence data, the ex-type strain (MFLUCC 150177) of $V$. chlamydospora clustered in the Septoriella clade. Therefore, we transfer $V$. chlamydospora to Septoriella. This species was reported on dead stem of Dactylis sp. (Poaceae) from Italy (Jayasiri et al. (2015b).

Septoriella tridentina Thambugala, Camporesi \& K.D. Hyde, sp. nov.

Fig. 40

Index Fungorum number: IF552992, Facesoffungi number: FoF 03211

Etymology - Referring to the province of Trento, where the species was encountered Holotype - MFLU 16-2567 

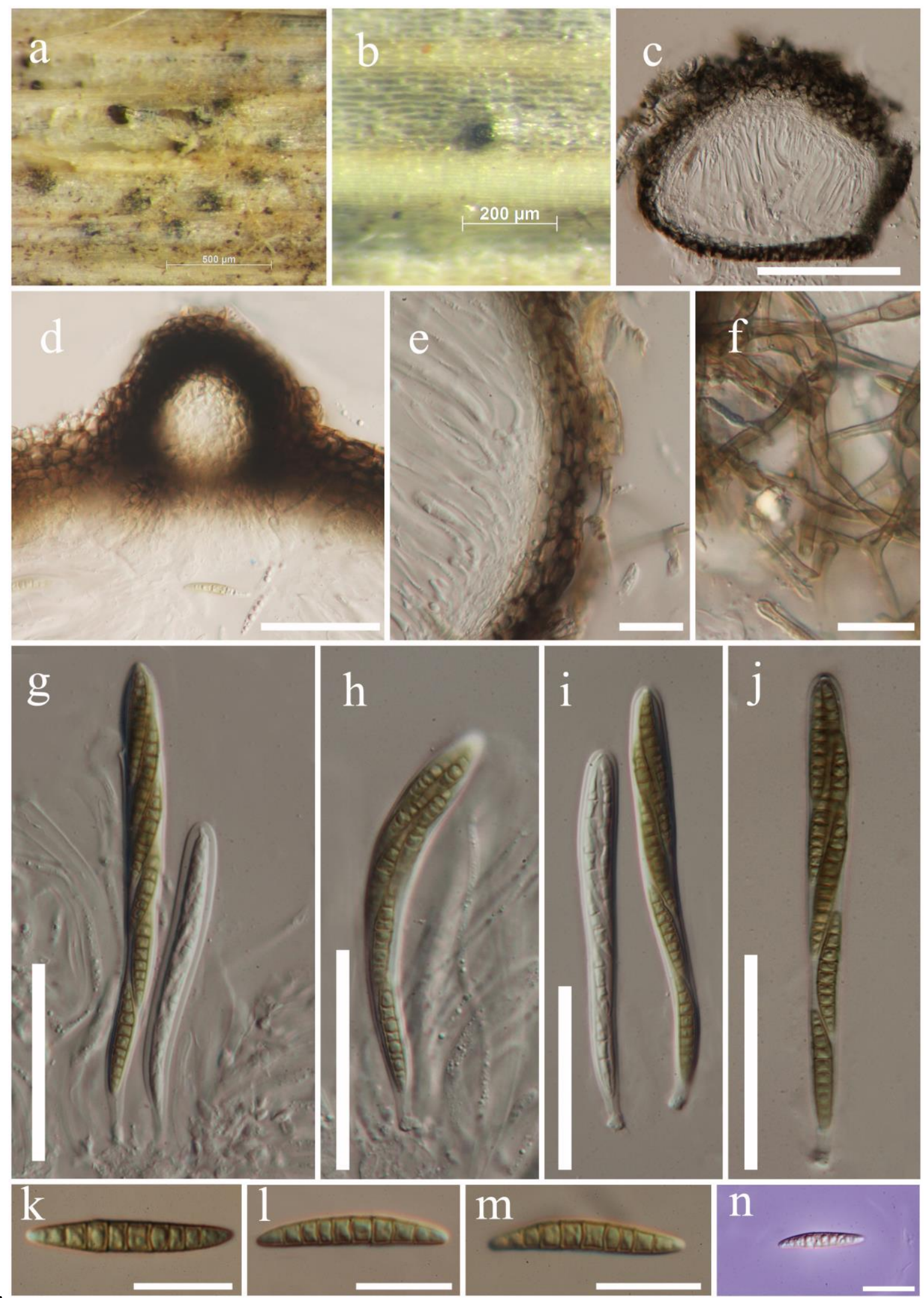

Fig. 38 - Poaceicola garethjonesii (MFLU 15-2626, holotype). a, b. Appearance of ascomata on the host surface. c. Vertical sections through ascomata. d. Apex of ascoma e. Peridium $\mathrm{f}$. Dark brown vegetative hyphae. $\mathrm{g}-\mathrm{j}$. Mature and immature asci (note pseudoparaphyses in $\mathrm{h}$ ). $\mathrm{k}-\mathrm{n}$. Ascospores. Scale bars: $\mathrm{c}=100 \mu \mathrm{m}, \mathrm{d}, \mathrm{g}-\mathrm{j}=50 \mu \mathrm{m}, \mathrm{e}, \mathrm{f}=20 \mu \mathrm{m}, \mathrm{k}-\mathrm{n}=15 \mu \mathrm{m}$ 
Table 3 Synopsis of Poaceicola species (sexual morph).

\begin{tabular}{|c|c|c|c|c|}
\hline Species & Septa & Ascospores $(\mu \mathrm{m})$ & Host & Reference \\
\hline $\begin{array}{l}\text { Poaceicola } \\
\text { forlicesenica }\end{array}$ & $(6-) 7$ & $\begin{array}{l}26-31 \times 4.2-5.4 \\
(\bar{x}=28.2 \times 4.7, \mathrm{n} \\
=30)\end{array}$ & $\begin{array}{l}\text { Dactylis } \\
\text { glomerata }\end{array}$ & This study \\
\hline $\begin{array}{l}\text { Poaceicola } \\
\text { italica }\end{array}$ & $10-11$ & $\begin{array}{l}35-42.5 \times 4.7- \\
6.5(\bar{x}=38.5 \times \\
5.7, \mathrm{n}=25)\end{array}$ & Arundo plinii & This study \\
\hline $\begin{array}{l}\text { Poaceicola } \\
\text { garethjonesii }\end{array}$ & $(7-) 8(-9)$ & $\begin{array}{l}27-32 \times 4-4.8 \\
(\bar{x}=30 \times 4.5, \mathrm{n}= \\
35)\end{array}$ & $\begin{array}{l}\text { Dactylis } \\
\text { glomerata }\end{array}$ & This study \\
\hline $\begin{array}{l}\text { Poaceicola } \\
\text { elongata }\end{array}$ & 10 & $\begin{array}{l}44-52 \times 6-7 \\
(-8)(\bar{x}= \\
50 \times 6, \mathrm{n}=20)\end{array}$ & $\begin{array}{l}\text { Calamagrostis } \\
\text { canadensis } \\
\text { (Michx.) Beauv. } \\
\text { Elymus glaucus } \\
\text { Buckl., } \\
\text { Calamagrostis } \\
\text { purpurea Trin. }\end{array}$ & $\begin{array}{l}\text { Shoemaker } \\
\& \text { Babcock } \\
(1989)\end{array}$ \\
\hline $\begin{array}{l}\text { Poaceicola } \\
\text { arundinis }\end{array}$ & $(5-) 8-9$ & $\begin{array}{l}23-34 \times 4.5-8(\bar{x} \\
=29 \times 6, \mathrm{n}=30),\end{array}$ & $\begin{array}{l}\text { Arundo plinii } \\
\text { Dactylis sp. }\end{array}$ & $\begin{array}{l}\text { Hyde et al. } \\
(2016)\end{array}$ \\
\hline $\begin{array}{l}\text { Poaceicola } \\
\text { dactylidis }\end{array}$ & 7 & $\begin{array}{l}14-19 \times 3-4(\bar{x}= \\
16 \times 3, \mathrm{n}=15)\end{array}$ & Dactylis sp. & This study \\
\hline
\end{tabular}

Saprobic on dead stems of Dactylis glomerata L. Sexual morph: Ascomata 115-180 $\mu \mathrm{m}$ diameter $\times 90-150 \mu \mathrm{m}$ high $(\bar{x}=132 \times 110 \mu \mathrm{m}, \mathrm{n}=7)$, immersed, becoming erumpent at maturity, solitary or aggregated in a small group, scattered, subglobose to conical, with a flattened base, coriaceous, dark brown to black, ostiolate. Peridium 10-15 $\mu \mathrm{m}$ wide, comprising a few layers of thick-walled, dark brown to lightly pigmented cells of textura angularis. Hamathecium comprising 1.5-2 $\mu \mathrm{m}$ wide, cellular, septate, rarely branched pseudoparaphyses, with small guttules. Asci 60$90 \times 11-15 \mu \mathrm{m}(\bar{x}=70 \times 12.8 \mu \mathrm{m}, \mathrm{n}=20), 8$-spored, bitunicate, fissitunicate, cylindrical to cylindric-subclavate, strait or slightly curved, short pedicellate, apically rounded, with an ocular chamber. Ascospores 25-33 × 4.4-5.4 $\mu \mathrm{m}(\bar{x}=29 \times 5 \mu \mathrm{m}, \mathrm{n}=35)$, overlapping 2-3-seriate, hyaline to pale yellowish brown, cylindric-fusiform, 5-6-septate, tapering towards the rounded ends, enlarged at the second or third cell from the apex, straight to slightly curved, slightly constricted at the septa, sometimes guttulate, smooth-walled, surrounded by a mucilaginous sheath. Asexual morph: Undetermined.

Culture characteristics - Ascospores germinating on PDA within $24 \mathrm{~h}$ and producing germ tubes from one or several cells. Colonies growing on PDA, reaching a diameter of $18 \mathrm{~mm}$ after $7 \mathrm{~d}$ at $25{ }^{\circ} \mathrm{C}$, flat to slightly raised, surface smooth to velvety, with entire to slightly undulate edge, iron-grey to white, dense, circular; reverse buff to dark brown.

Material examined - ITALY, Province of Trento [TN], near Marilleva 900 - Mezzana, on dead aerial stem of Dactylis glomerata L. (Poaceae), 11 August 2014, Erio Camporesi IT 2046 (MFLU 16-2567, holotype); ibid. (GZAAS 16-0117, isotype), ex-type living culture MFLUCC 15-0474, ICMP 21423; ibid. IT 2046-2 (MFLU 16-2568, paratype), ex-paratype living culture MFLUCC 15-0475.

Notes - Septoriella tridentina is identified as a new species based on both the morphological traits and phylogeny. Septoriella tridentina is similar to other reported sexual species of Septoriella, S. chlamydospora in having immersed ascomata becoming erumpent at maturity and 


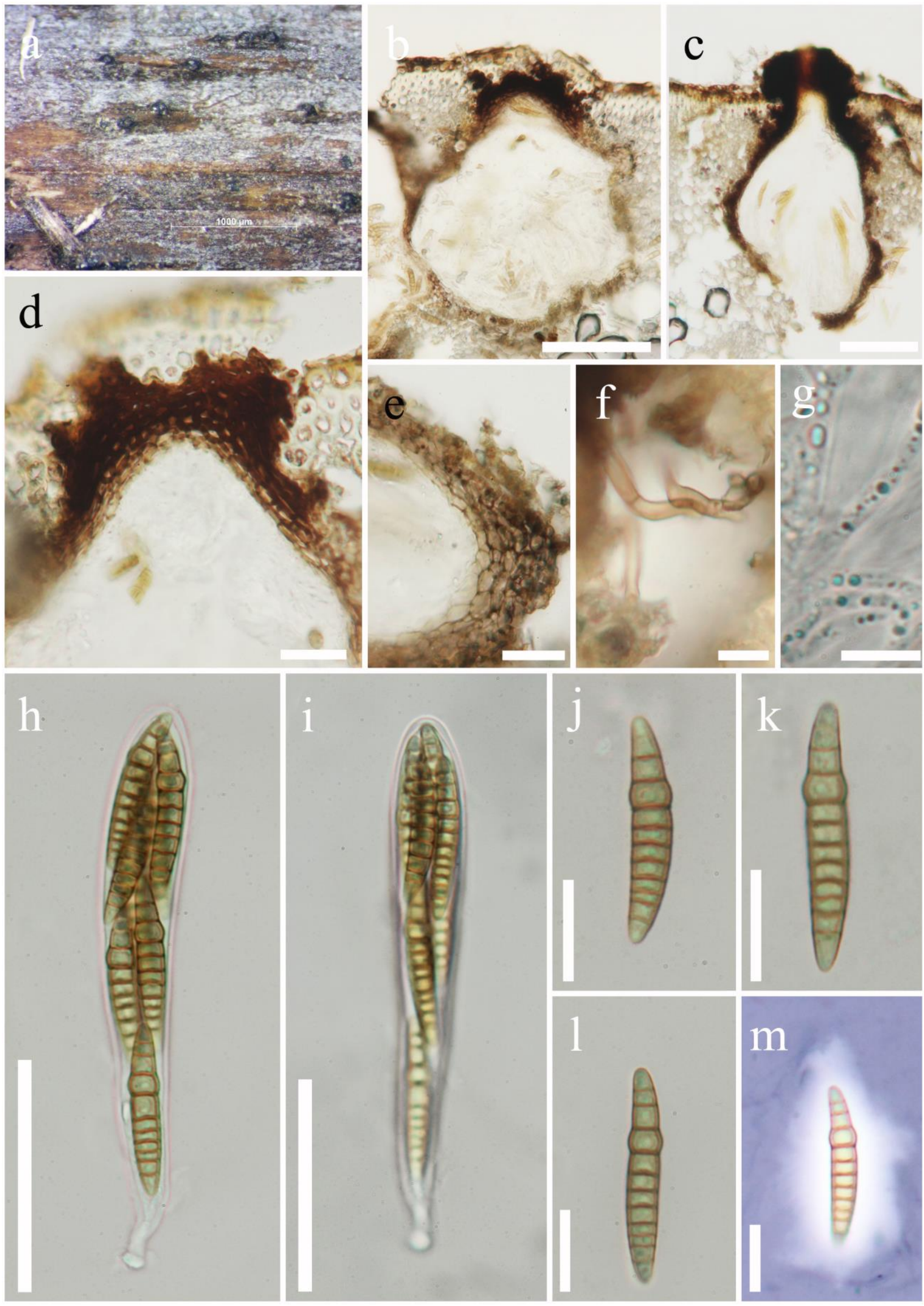

Fig. 39 - Poaceicola italica (MFLU 15-0547, holotype). a. Appearance of ascomata on the host surface. b, c. Vertical sections through ascomata. d. Apex of ascoma e. Peridium. f. Dark brown vegetative hyphae. g. Pseudoparaphyses. h, i. Asci j-l. Ascospores. m. Ascospore stained in Indian ink. Scale bars: $\mathrm{b}, \mathrm{c}=100 \mu \mathrm{m}, \mathrm{d}, \mathrm{e}=25 \mu \mathrm{m}, \mathrm{f}, \mathrm{g}=10 \mu \mathrm{m}, \mathrm{h}-\mathrm{i}=50 \mu \mathrm{m}, \mathrm{j}-\mathrm{m}=15 \mu \mathrm{m}$. 
fusiform, phragmosporous, hyaline to pale yellowish brown ascospores. However, $S$. chlamydospora has 9-septate ascospores, while S. tridentina with 5-6-septate ascospores.

Setophoma Gruyter, Aveskamp \& Verkley, in de Gruyter, Woudenberg, Aveskamp, Verkley, Groenewald \& Crous, Mycologia 102(5): 1077 (2010)

Setophoma was introduced by de Gruyter et al. (2010) to accommodate Phoma terrestris H.N. Hansen and Pyrenochaeta sacchari Bitancourt in the family Phaeosphaeriaceae. There are five species currently listed in Index Index Fungorum (2017).

Setophoma poaceicola Goonas., Thambugala \& K.D. Hyde, sp. nov.

Fig. 41

Index Fungorum number: IF552993, Facesoffungi number: FoF 03212

Etymology - in reference to holotype occurring on grasses (Poaceae).

Holotype - MFLU 16- 2850

Saprobic on dead culm of grass, appearing as black, flat to slightly raised lesions, sometimes coalescing creating larger lesions. Sexual morph: Ascomata 90-110 $\mu \mathrm{m}$ high, $70-100 \mu \mathrm{m}$ diameter, perithecial, solitary, scattered to gregarious, glabrous, globose, dark brown to black, with a centrally located short ostiole. Peridium 10-15 $\mu \mathrm{m}$ wide, composed of several layers of outer thick-walled, cells of textura prismatica and inner, hyaline cells of textura prismatica to textura angularis. Hamathecium comprising many, filamentous, $0.5-1 \mu \mathrm{m}$ wide, indistinctly septate, anastomosing pseudoparaphyses. Asci 30-70 × 6.5-8 $\mu \mathrm{m}(\bar{x}=48.5 \times 7 \mu \mathrm{m}, \mathrm{n}=20)$, 8-spored, bitunicate, fissitunicate, cylindrical, with a short pedicel, apex rounded, ocular chamber present. Ascospores 14-16 $\times 3-4 \mu \mathrm{m}(\bar{x}=15 \times 3.5 \mu \mathrm{m}, \mathrm{n}=20)$, overlapping 1-2-seriate, light brown, fusiform, with acute ends, 3-septate, smooth-walled, guttulate. Asexual morph: Undetermined.

Culture characteristics - Conidia germinating on PDA within $12 \mathrm{~h}$, growing into an irregular colony, reaching a diameter of $15 \mathrm{~mm}$ after $7 \mathrm{~d}$ at $25{ }^{\circ} \mathrm{C}$, flat with a filamentous margin, dull and wrinkled surface, opaque, dark brown, orange-brown at the margin; reverse same.

Material examined - THAILAND, Chiang Mai Province, Mae Taeng, Mushroom Research Center, on culm of dead grass (Poaceae), 9 March 2016, Ishani D. Goonasekara IGm 05 (MFLU 16-2850, holotype); ibid. (HKAS 97386, isotype), ex-type living culture MFLUCC 16-0880, KUMCC 17-0021.

Notes - This is the second record of the sexual morph of the genus Setophoma from Thailand and the first report was S. sacchari (Bitanc.) Gruyter, Aveskamp \& Verkley. Setophoma poaceicola mainly differs from $S$. sacchari in having smaller $(22.5 \times 5.6 \mu \mathrm{m}$ in $S$. sacchari $)$, light brown ascospores, while $S$. sacchari causes a ring spot disease on sugarcane (Phookamsak et al. 2014b). In the present phylogenetic analysis the ex-type strain of $S$. poaceicola forms a strongly supported clade (100\% ML) within the genus and clearly separated from the other species (Fig. 26).

Vagicola K.W.T. Chethana \& K.D. Hyde, in Ariyawansa et al., Fungal Diversity: 75: 113 (2015)

$=$ Phaeosphaeria subgen. Vagispora Shoemaker \& Babcock, Can. J. Bot. 67: 1500-1599 (1989)

Ariyawansa et al. (2015a) raised the subgenus Vagicola (Shoemaker \& Babcock 1989) to generic rank to accommodate Phaeosphaeria vagans Niessl. Subsequently Jayasiri et al. (2015b) introduced two new species to the genus namely, $V$. chlamydospora and $V$. dactylidis.

Vagicola arundinis Phukhamsakda, Camporesi \& K.D. Hyde, sp. nov.

Figs $42 \& 43$

Index Fungorum number: IF552985, Facesoffungi number: FoF 03208

Etymology - Named after the host genus from which it was collected, Arundo.

Holotype - MFLU 17-0016 \& MFLU 17-0017

Saprobic on dead branch of Arundo plinii Turra. Sexual morph: Ascomata 230-345 $\mu \mathrm{m}$ high $\times 279-323 \mu \mathrm{m}$ diameter $(\bar{x}=329 \times 310 \mu \mathrm{m}, \mathrm{n}=5)$, immersed to erumpent, only ostioles part visible, gregarious, confluence, globose to depressed globose, with attached hyphae, coriaceous, black to dark brown, ostiole central. Ostioles $154-164 \mu \mathrm{m}$ high $\times 109-143 \mu \mathrm{m}$ diameter $(\bar{x}=126 \times$ $159 \mu \mathrm{m}, \mathrm{n}=3$ ), papillate, dark brown, smooth, with periphyses. Peridium 19-29 $\mu \mathrm{m}$ wide., up to 40 


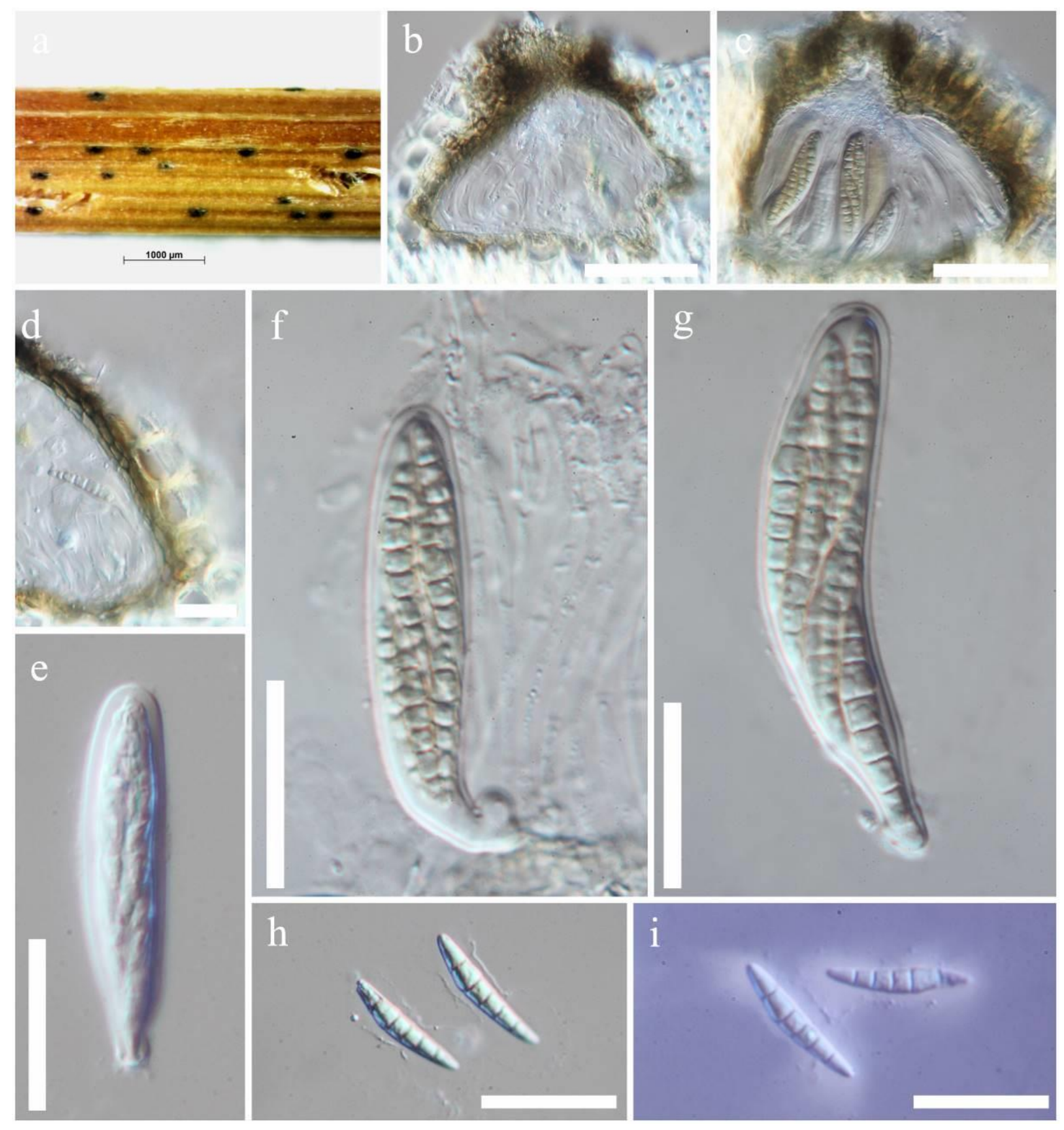

Fig. 40 - Septoriella tridentina (MFLU 16-2567, holotype). a. Appearance of ascomata on the host surface. b, c. Vertical sections through ascomata. d. Peridium e. Immature ascus f, g. Mature asci (note pseudoparaphyses in f). h. Ascospores i. Ascospores stained in Indian ink. Scale bars: $b=20$ $\mu \mathrm{m}, \mathrm{e}-\mathrm{i}=25 \mu \mathrm{m}$.

$\mu \mathrm{m}$ wide at the apex, composed of 8-10 layers of textura angularis, outer region haeavily pigment, cells 4-8 $\mu \mathrm{m}$ wide, inner layer composed of hyaline gelatinous cell, merging with psedoparaphyses. Hamathecium comprising numerous, long, 1.8-3 $\mu \mathrm{m}(\mathrm{n}=30)$ wide, broad, transversely septate, branched, cellular pseudoparaphyses. Asci 84-153 x 10-20 $\mu \mathrm{m}(\bar{x}=111 \times 15 \mu \mathrm{m}, \mathrm{n}=20)$, 8spored, bitunicate, clavate, with furcate pedicel, $15-25 \mu \mathrm{m}$ long, apically rounded, with an ocular chamber well visible when immature. Ascospores 34-45 $\times 5-7 \mu \mathrm{m}(\bar{x}=37 \times 6 \mu \mathrm{m}, \mathrm{n}=30)$, overlapping 2-seriate, hyaline when immature, pale brown to yellowish at maturity, narrowly fusiform, tapering towards the ends, (5-)8-9-septate, distoseptate, slightly contricted at the fouth cell, enlarged at the fouth cell from apex, smooth-walled. Asexual morph: Conidiomata 95-169 
$\mu \mathrm{m}$ high $\times 240-290 \mu \mathrm{m}$ diameter $(\bar{x}=136 \times 282 \mu \mathrm{m}, \mathrm{n}=10)$, pycnidial, solitary or in small groups, brown to dark brown, globose, immersed to semi-immersed, clypeus, appeared as black dot on host tissue, rise up from host, solitary, scattered, uniloculate, ostiolate. Peridium 7-16 $\mu \mathrm{m}$ wide, thickwalled, comprising 4-5 layers, comprising of brown-walled cells of textura angularis. Ostiole central, roundish, single. Conidiophores reduced to conidiogenous cells. Conidiogenous cells $1-3 \times$ 2-5 $\mu \mathrm{m},(\bar{x}=3 \times 4 \mu \mathrm{m}, \mathrm{n}=20)$, holoblastic, solitary, phialidic blastoconidia, discrete, hyaline, formed from the inner layer of pycnidial wall. Conidia 7-13 $\times 2-6 \mu \mathrm{m}(\bar{x}=9.8 \times 3.8 \mu \mathrm{m}, \mathrm{n}=50)$, ellipsoid, subfusiform, narrowly rounded at both ends, 1-3 transverse septa at maturity, hyaline immature, pale brown to brown when mature.

Culture characteristics - Colonies on PDA, reaching $40 \mathrm{~mm}$ diameter after $30 \mathrm{~d}$ at $16^{\circ} \mathrm{C}$, surface white, with aerial mycelium, fluffy, entire margins; reverse pale orange at the edges, light brown at the centre, radiating orange outward, sparse, circular, flattened, margin rough.

Material examined - ITALY, Province of Marsignano - Predappio, on a dead stem of Arundo plinii (Poaceae), 10 November 2014, Erio Camporesi IT 2223A (MFLU 17-0016, holotype - sexual morph); ibid. (HKAS, isotype); ex-type living culture MFLUCC 15-0027, KUMCC; ibid. (IT 2223B, MFLU 17-0017, asexual morph), living culture MFLUCC 15-0046.

Notes - Vagicola arundinis is introduced as a new species and both sexual and asexual morphs are described and illustrated in this study. This species primarily differs from other Vagicola species in having narrowly fusiform, (5-)8-9-septate ascospores and 1-3 transverse septate conidia.

Pleosporaceae Nitschke, Verh. naturh. Ver. preuss. Rheinl. 26: 74 (1869)

Ariyawansa et al. (2015b) revised the family and accepted 18 genera. A number of members of this family are associated with a wide range of grasses (Poaceae) worldwide (Manamgoda et al. 2012, Ariyawansa et al. 2014b, 2015b, Woudenberg et al. 2015).

Alternaria Nees, Syst. Pilze (Würzburg): 72. 1816 [1816-1817]

Alternaria is a cosmopolitan fungal genus that consists of saprobic, endophytic and pathogenic species associated with a wide variety of substrates. There are a lot of synonyms under Alternaria and the genus is currently divided into 26 sections (Ariyawansa et al. 2015b, Woudenberg et al. 2013, 2015).

Alternaria alternata (Fr.) Keiss1., Beih. bot. Zbl., Abt. 2 29: 434 (1912)

Fig. 46

Pathogenic or saprobic on a wide range of hosts. Sexual morph: See Ariyawansa et al. (2015). Asexual morph: Conidiophores 35-230 × 4- $7 \mu \mathrm{m}(\bar{x}=100 \times 5.2 \mu \mathrm{m}, \mathrm{n}=50)$, short to long, simple or branched, straight or flexuous, pale, olivaceous or brown, smooth, septate, with one or several apical conidiogenous loci. Conidia 20-100 $\times 9-17 \mu \mathrm{m}(\bar{x}=45 \times 12 \mu \mathrm{m}, \mathrm{n}=70)$, simple or branched chains, obclavate, obpyriform, ovoid or ellipsoidal, pale to mid dark brown, up to 6 transverse and usually few longitudinal or oblique septa, slightly constricted near some septa, smooth-walled or slightly verrucose.

Culture characteristics - Conidia germinating on PDA within $24 \mathrm{~h}$ and germ tubes produced from several cells. Colonies growing on PDA, reaching a diameter of $45 \mathrm{~mm}$ after $5 \mathrm{~d}$ at $25^{\circ} \mathrm{C}$, flat to slightly umbonate, surface smooth to velvety, with entire edge, grey to white, dense to moderately dense, circular; reverse pale orange buff.

Material examined - CHINA, Guizhou Province, Guizhou Academy of Agricultural Sciences, on dead leaves of bamboo sp. (Poaceae), 20 July 2015, K.M. Thambugala CN019 (MFLU 16-2588, GZAAS 16-0034), living culture MFLUCC 16-0595, GZCC 15-0044; ibid., on dead leaves of Triticum aestivum L. (Poaceae), 16 May 2015, K.M. Thambugala CN002 (MFLU 16-2589, GZAAS 16-0021), living culture MFLUCC 16-0343, GZCC 15-0031; ibid., on dead kernels of Triticum aestivum L. (Poaceae), 10 June 2015, K.M. Thambugala CN015 (MFLU 162590, GZAAS 16-0030), living culture MFLUCC 16-0279, GZCC 15-0040; ibid., dead leaves of Sorghum bicolor (L.) Conrad Moench (Poaceae), 20 July 2015, K.M. Thambugala CN016 (MFLU 

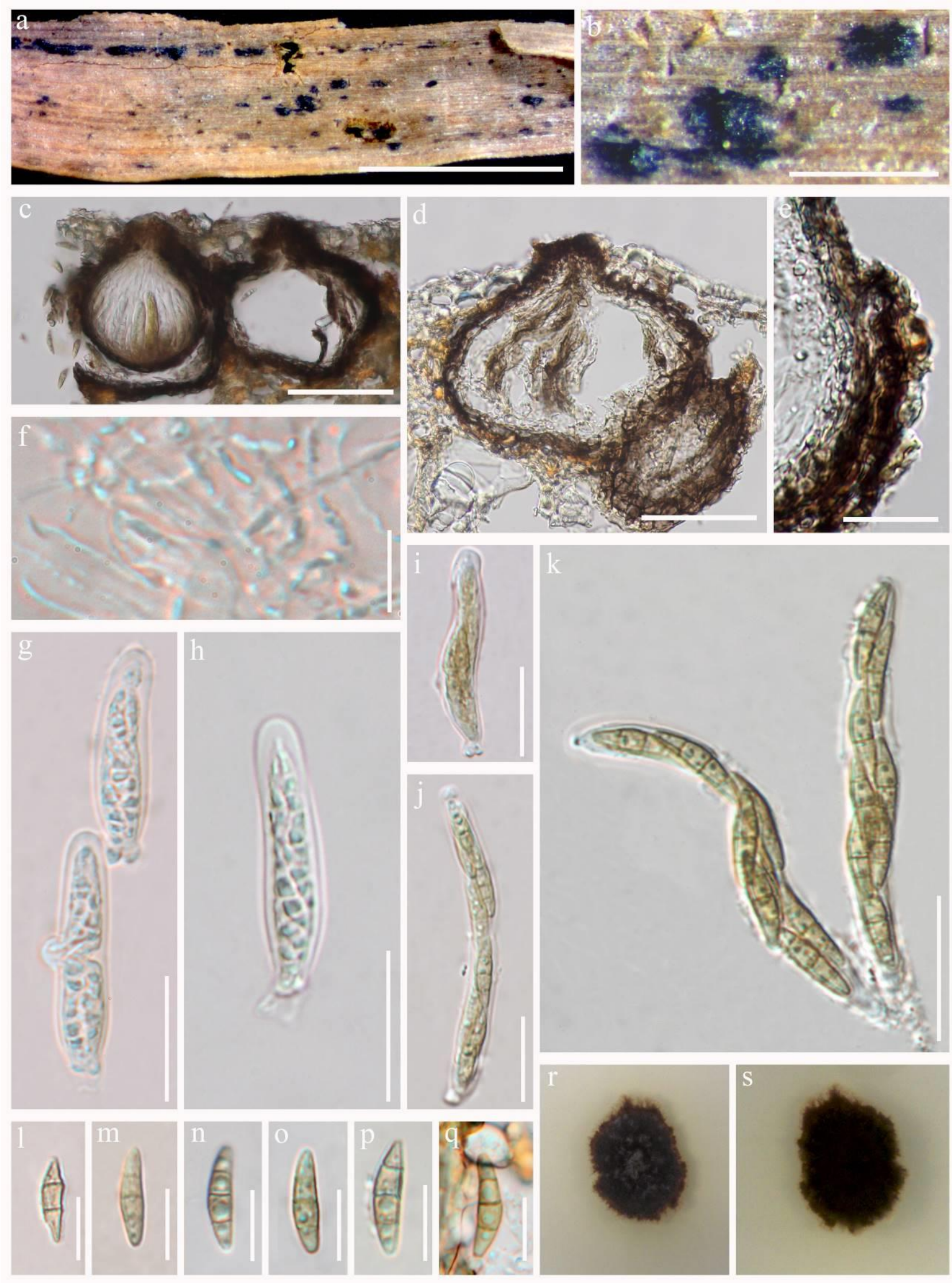

Fig. 41 - Setophoma poaceicola (MFLU 16-2850, holotype). A. Appearance of ascomata on host surface b. Close up of ascomata $c$, d. Vertical sections through ascomata e. Peridium f. Pseudoparaphyses g-k. Asci l-q. Ascospores r. Colony - from above s. Colony - from below. Scale bars: $\mathrm{a}=1000 \mu \mathrm{m}, \mathrm{b}=200 \mu \mathrm{m}, \mathrm{c}=100 \mu \mathrm{m}, \mathrm{d}, \mathrm{g}=50 \mu \mathrm{m}, \mathrm{e}, \mathrm{f}, \mathrm{h}-\mathrm{k}=20 \mu \mathrm{m}, \mathrm{l}-\mathrm{q}=10 \mu \mathrm{m}$. 

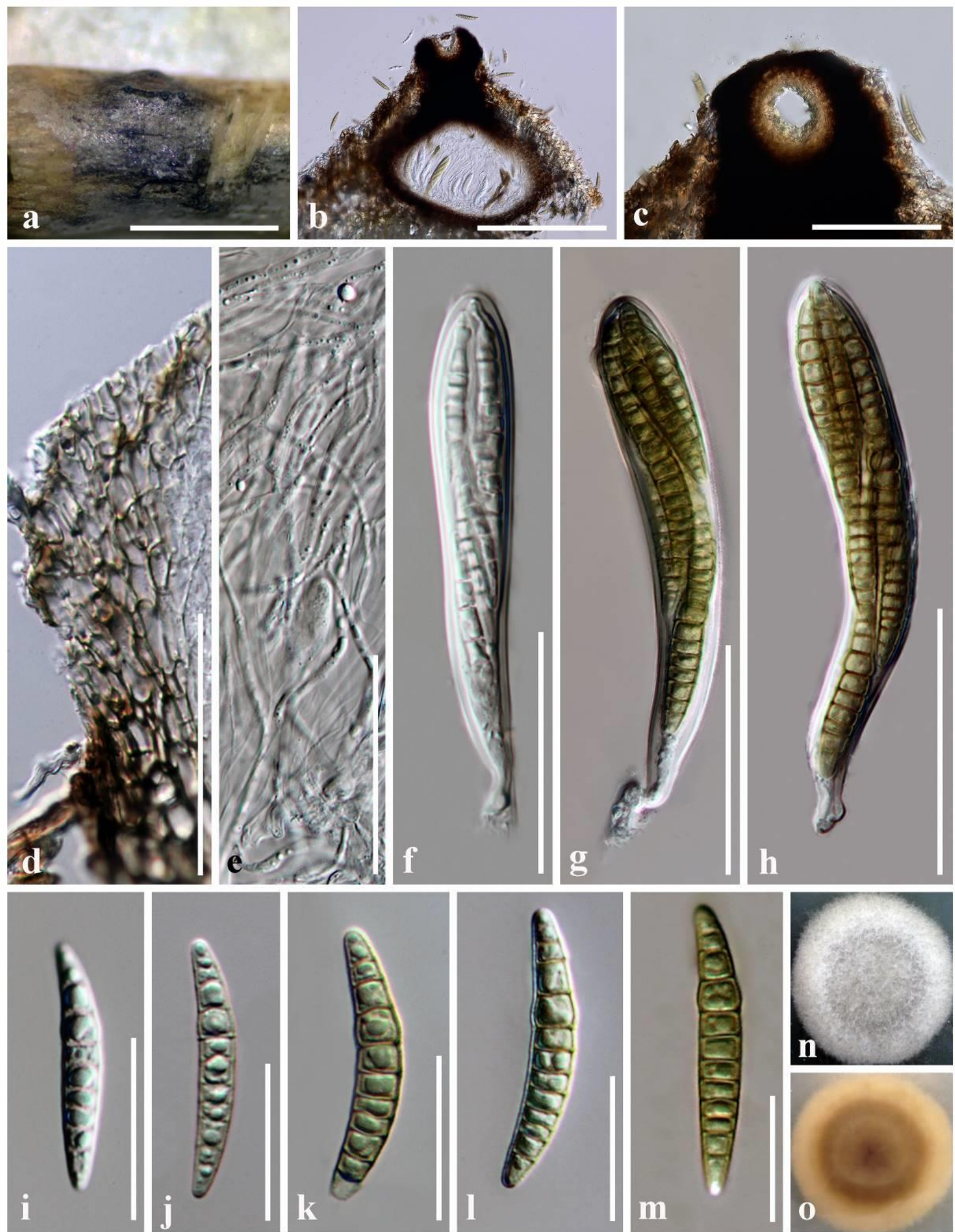

Fig. 42 - Vagicola arundinis (MFLU 17-0016, holotype - sexual morph). a. Appearance of ascomata on host surface. b. Vertical section of ascoma. c. Ostiole. d. Peridium. e. Pseudoparaphyses. $\mathrm{f}-\mathrm{h}$. Development state of asci. i-m. Development of ascospores. $\mathrm{n}-\mathrm{o}$. Culture character on PDA from surface and reverse. Scale bars: $\mathrm{a}=500 \mu \mathrm{m}, \mathrm{b}=100 \mu \mathrm{m}, \mathrm{c}=100 \mu \mathrm{m}, \mathrm{d}-\mathrm{h}$ $=50 \mu \mathrm{m}, \mathrm{i}-\mathrm{m}=20 \mu \mathrm{m}$. 

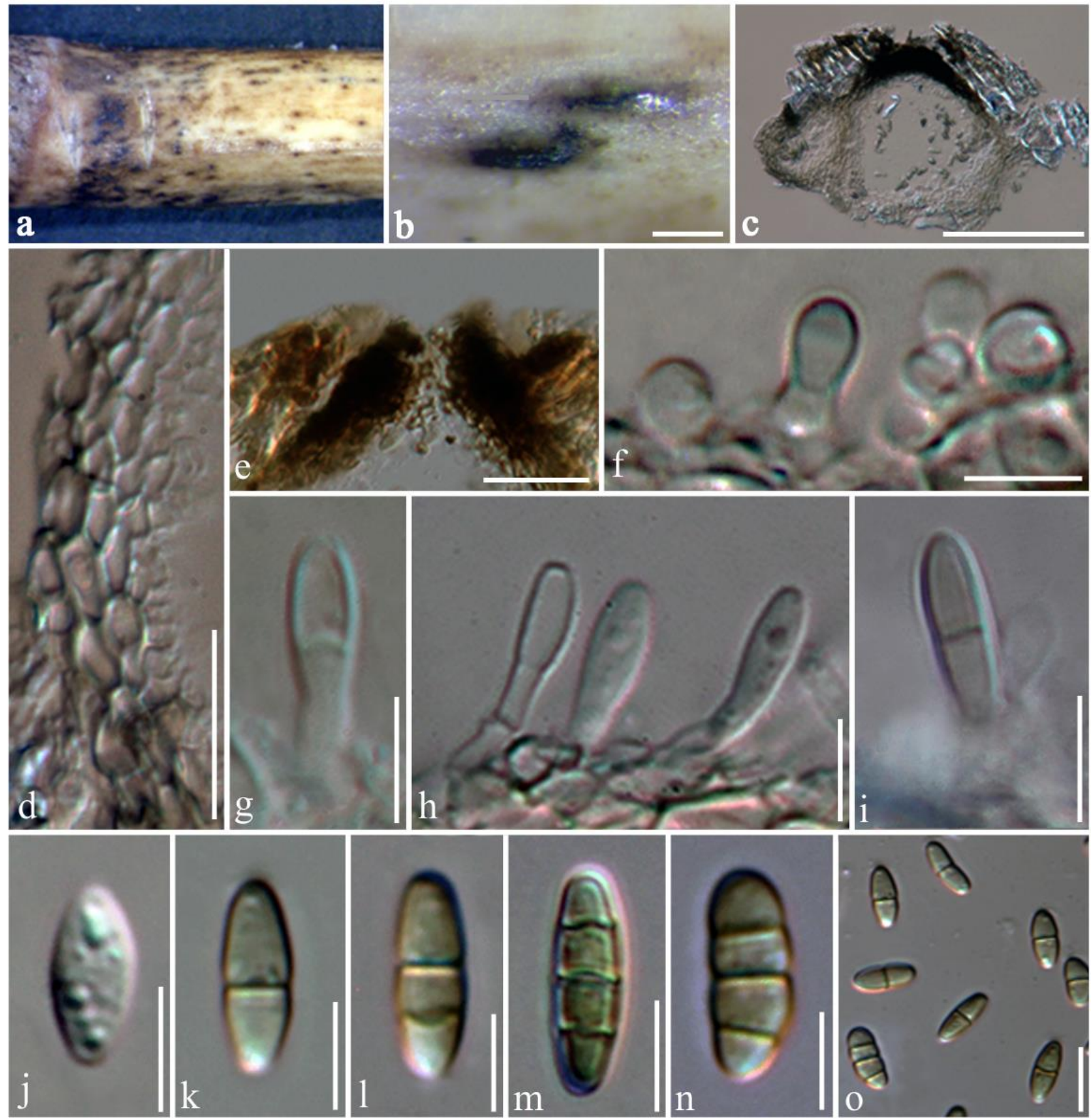

Fig. 43 - Vagicola arundinis (MFLU 17-0017, holotype - asexual morph). a-b. Appearance of conidiomata on host surface. c. Vertical section of conidiomata. d. Conidiomatal wall. e. Ostiole. fi. Development of conidia. j-o. Conidia. Scale bar: $\mathrm{b}=200 \mu \mathrm{m}, \mathrm{c}=100 \mu \mathrm{m}, \mathrm{d}-\mathrm{e}=20 \mu \mathrm{m}, \mathrm{f}-\mathrm{n}=5$ $\mu \mathrm{m}, \mathrm{o}=10 \mu \mathrm{m}$.

16-2591, GZAAS 16-0031), living culture MFLUCC 16-0280, GZCC 15-0041; ibid., on dead leaves of Triticum aestivum L. (Poaceae), 20 July 2015, K.M. Thambugala CN001 (MFLU 162592, GZAAS 16-0020), living culture MFLUCC 16-0594, GZCC 15-0030

Notes - Alternaria alternata belongs to the Alternaria sect. Alternaria, which consists of only eleven phylogenetic species and one species complex (Woudenberg et al. 2015). Woudenberg et al. (2015) listed many synonyms under A. alternata based on genome and transcriptome comparisons and molecular phylogenies. Alternaria alternata occurs on a number of substrates worldwide and we collected the species associated with Sorghum bicolor (L.) Conrad Moench, 
Triticum aestivum L., and bamboo sp. in china and slightly different conidial morphology was observed among those collections (Fig. 45).

Alternaria dactylidicola Thambugala, Camporesi \& K.D. Hyde, sp. nov.

Fig. 47

Index Fungorum number: IF553166, Facesoffungi number: FoF 03227

Etymology - Named after the host genus from which it was collected, Dactylis.

Holotype - MFLU 15-2622

Saprobic on Dactylis glomerata L. Sexual morph: Ascomata 175-225 $\mu \mathrm{m}$ diameter $\times 125$ $150 \mu \mathrm{m}$ high $(\bar{x}=190 \times 140 \mu \mathrm{m}, \mathrm{n}=4)$, scattered or clustered, semi-immersed to erumpent, black, subglobose, coriaceous, ostiolate. Peridium 12-20 $\mu \mathrm{m}$ wide, comprising 3-5, cell layers of dark brown to lightly pigmented, thick-walled cells of textura angularis. Hamathecium composed of 1-2 $\mu \mathrm{m}$ wide, filiform, septate, rarely branched, pseudoparaphyses anastomosing between and above asci. Asci $60-85 \times 12-14.5 \mu \mathrm{m}(\bar{x}=74 \times 13.5 \mu \mathrm{m}, \mathrm{n}=12), 8$-spored, bitunicate, fissitunicate, cylindrical to subcylindrical, straight or somewhat curved, with a short pedicel and apically rounded with an ocular chamber. Ascospores 14-17.5 $\times 6-8 \mu \mathrm{m}(\bar{x}=15.8 \times 7 \mu \mathrm{m}, \mathrm{n}=30)$, partially overlapping 1-2-seriate, ellipsoid to fusoid, initially yellowish, becoming pale brown to brown, muriform, transversely 3-5-septate, with 2-4 vertical septa, with rounded to somewhat pointed ends, smooth-walled, with a thin mucilaginous sheath. Asexual morph: Undetermined.

Culture characteristics - Ascospores germinating on PDA within $24 \mathrm{~h}$ and germ tubes produced from several cells. Colonies growing on PDA, reaching a diameter of $38 \mathrm{~mm}$ after $5 \mathrm{~d}$ at $25{ }^{\circ} \mathrm{C}$, flat, surface smooth to velvety, with entire edge, grey at the middle, white at the margin, moderately dense, circular; reverse grey to black to white.

Material examined - ITALY, Province of Forlì-Cesena [FC], near Passo delle Forche Galeata, on dead aerial stem of Dactylis glomerata L. (Poaceae), 7 April 2014, Erio Camporesi IT 1802 (MFLU 15-2622, holotype); ibid. (GZAAS 16-0132, isotype), ex-type living culture MFLUCC 15-0466, ICMP 21430

Notes - Alternaria dactylidicola morphologically and phylogenetically closely resembles $A$. cesenica Phukhamsakda et al. However, A. dactylidicola differs from A. cesenica in having a thin peridium and smaller, transversely 3-5-septate, uni to biseriately arranged ascospores with a mucilaginous sheath. Alternaria dactylidicola is associated with dead stems of Dactylis glomerata L. (Poaceae), while A. cesenica was reported on dead and hanging branches of Bellevalia romana (Asparagaceae) (Ariyawansa et al. 2015a). Therefore, A. dactylidicola is described here as a new species.

Alternaria forlicesenensis Thambugala, Camporesi \& K.D. Hyde, sp. nov.

Fig. 48

Index Fungorum number: IF553167, Facesoffungi number: FoF 03228

Etymology - Referring to the province Forlì-Cesena, where the species was encountered.

Holotype - MFLU 15-0560

Saprobic on dead stem of Dactylis glomerata L. Sexual morph: Ascomata 100-200 $\mu \mathrm{m}$ diameter $\times 130-220 \mu \mathrm{m}$ high $(\bar{x}=150 \times 156 \mu \mathrm{m}, \mathrm{n}=8)$, scattered to gregarious, semi-immersed to densely erumpent, elongate, black, subglobose, coriaceous, ostiolate. Peridium 15-25 $\mu \mathrm{m}$ wide, dark brown to lightly pigmented, thick-walled cells of textura angularis and attached short, brown to reddish brown, setae at the outer layer. Hamathecium of 1-2 $\mu \mathrm{m}$ wide, filiform, septate, pseudoparaphyses, anastomosing between and above asci. Asci $78-125 \times 11-14 \mu \mathrm{m}(\bar{x}=98 \times 12$ $\mu \mathrm{m}, \mathrm{n}=15), 8$-spored, bitunicate, fissitunicate, cylindrical to subcylindrical, straight or somewhat curved, with a short pedicel and apically rounded with an ocular chamber. Ascospores 16.3-19 $\times$ 6.4-8.3 $\mu \mathrm{m}(\bar{x}=17.4 \times 7.2 \mu \mathrm{m}, \mathrm{n}=30)$, partially overlapping 1-seriate, ellipsoid to fusoid, initially yellowish, becoming pale brown to brown, muriform, transversely (4-)5-septate, with (2-)3-4 vertical septa, with rounded to pointed ends, smooth-walled, surrounded by a mucilaginous sheath. Asexual morph: Undetermined.

Culture characteristics - Ascospores germinating on PDA within $24 \mathrm{~h}$ and germ tubes produced from several cells. Colonies growing on PDA, reaching a diameter of $60 \mathrm{~mm}$ after $7 \mathrm{~d}$ at 
$25{ }^{\circ} \mathrm{C}$, flat, surface smooth to velvety, with entire edge, grey to white, dense to moderately dense, circular; reverse grey to black.

Material examined - ITALY, Province of Forlì-Cesena [FC], San Lorenzo in Noceto, on dead aerial stem of Dactylis glomerata L. (Poaceae), 6 February 2013, Erio Camporesi IT 993 (MFLU 15-0560, holotype); ibid. (GZAAS 16-0131, isotype), ex-type living culture MFLUCC 13-0456, ICMP 21559

Notes - Alternaria forlicesenensis is described here as a new species that is morphologically similar to A. infectoria E.G. Simmons (=Lewia infectoria (Fuckel) M.E. Barr \& E.G. Simmons). However, A. forlicesenensis differs from A. infectoria in having smaller ascomata with short, brown to reddish-brown, setae and smaller ascospores surrounded by a mucilaginous sheath. In the present phylogenetic analysis, A. forlicesenensis and the ex-type strain of A. infectoria (CBS 210.86) grouped separately in the section Infectoriae. Alternaria forlicesenensis was associated with dead stems of Dactylis glomerata L., while A. infectoria was reported on Triticum aestivum L. (Simmons 1993, Woudenberg et al. 2013).

Alternaria longipes (Ellis \& Everh.) E.W. Mason, Mycol. Pap. 2: 19 (1928)

Fig. 49

Basionym: Macrosporium longipes Ellis \& Everh., J. Mycol. 7: 134. 1892.

= Alternaria brassicae var. tabaci Preissecker, Fachliche Mitt. Österr. Tabakregie 16: 4. 1916.

Pathogenic or saprobic on Nicotiana tabacum L. and Triticum aestivum L. Sexual morph: Undetermined. Asexual morph: Conidiophores 60-260 × 4.5-6-(9) $\mu \mathrm{m}(\bar{x}=155 \times 5.8 \mu \mathrm{m}, \mathrm{n}=$ 20 ), short to long, simple, straight or flexuous, pale, olivaceous or brown, smooth, septate, with one or several apical conidiogenous loci. Conidia 30-60(-77) $\times(-7) 9.5-13.5(-16.2) \mu \mathrm{m}(\bar{x}=44 \times 11.2$ $\mu \mathrm{m}, \mathrm{n}=30$ ), simple or branched chains, obclavate, obpyriform, ovoid or ellipsoidal, pale to dark brown, up to 5 transverse and usually few longitudinal or oblique septa, slightly constricted near some septa, smooth to finely verrucose.

Culture characteristics - Conidia germinating on PDA within $18 \mathrm{~h}$ and germ tubes produced from several cells. Colonies growing on PDA, reaching a diameter of $40 \mathrm{~mm}$ after $7 \mathrm{~d}$ at $25^{\circ} \mathrm{C}$, flat to slightly umbonate, surface velvety, with entire to slightly undulate edge, grey, dense, circular to slightly irregular; reverse orange buff to greyish.

Material examined - CHINA, Guizhou Province, Guizhou Academy of Agricultural Sciences, on dead leaves of Triticum aestivum L. (Poaceae), 16 May 2014, K.M. Thambugala CN006 (MFLU 16-2595, GZAAS 16-0025, reference specimen designated here), living culture MFLUCC 16-0592, GZCC 15-0035

Notes - Alternaria longipes is commonly known as the causal agent of brown spot of tobacco (Nicotiana tabacum) and widely distributed in U.S.A. (Woudenberg et al. 2015). During our research, we found this species on Triticum aestivum L. from China and the present phylogenetic analysis confirms its identity (Fig. 45).

Alternaria poaceicola Thambugala, Camporesi \& K.D. Hyde, sp. nov.

Fig. 50

Index Fungorum number: IF553168, Facesoffungi number: FoF 03229

Etymology - in reference to holotype occurring on grasses (Poaceae)

Holotype - MFLU 16-2594

Saprobic on Dactylis glomerata L. Sexual morph: Ascomata 110-250 $\mu$ m diameter $\times 100$ $250(-350) \mu \mathrm{m}$ high $(\bar{x}=155 \times 190 \mu \mathrm{m}, \mathrm{n}=7)$, scattered or clustered, semi-immersed to erumpent, elongate, black, subglobose to irregular, with a somewhat flattened base, coriaceous, ostiolate. Peridium 20-30 $\mu \mathrm{m}$ wide, dark brown to hyaline, thick-walled cells of textura angularis, fusing with the host at the base. Hamathecium of 2-3 $\mu \mathrm{m}$ wide, filiform, septate, pseudoparaphyses, anastomosing between and above asci. Asci 75-105 $\times 10-14 \mu \mathrm{m}(\bar{x}=89 \times 11.8 \mu \mathrm{m}, \mathrm{n}=15), 8$ spored, bitunicate, fissitunicate, cylindrical to subcylindrical, straight or somewhat curved, with a short pedicel and apically rounded with an ocular chamber. Ascospores 14-17.5 (-19) $\times 6.2-8.8$ $\mu \mathrm{m}(\bar{x}=16 \times 7.2 \mu \mathrm{m}, \mathrm{n}=30)$, partially overlapping 1 -seriate, ellipsoid to fusoid, initially yellowish, becoming pale brown to brown, muriform, transversely 5 -septate, with $3-5$ vertical 
septa, with rounded to pointed ends, smooth-walled, surrounded by a mucilaginous sheath. Asexual morph: Undetermined.

Culture characteristics - Conidia germinating on PDA within $24 \mathrm{~h}$ and germ tubes produced from several cells. Colonies growing on PDA, reaching a diameter of $70 \mathrm{~mm}$ after $7 \mathrm{~d}$ at $25^{\circ} \mathrm{C}$, flat to slightly umbonate, surface smooth to velvety, with entire edge, grey to white, dense to moderately dense, circular; reverse grey to white.

Material examined - ITALY, Province of Forlì-Cesena [FC], Pietrapazza - Bagno di Romagna, on dead aerial stem of Dactylis glomerata L. (Poaceae), 6 January 2013, Erio Camporesi IT 1001 (MFLU 16-2594, holotype); ibid. (GZAAS 16-0126, isotype), ex-type living culture MFLUCC 13-0346, ICMP 21560

Notes - Alternaria poaceicola is introduced here as a new species that is known only by its sexual morph. Subglobose to irregular ascomata with a somewhat flattened base and poorly developed peridium are quite unique to this species compared to other sexual Alternaria species. Alternaria arbusti E.G. Simmons and A. oregonensis E.G. Simmons appear to be closest species of A. poaceicola and unfortunately, no sexual morphs have been reported for those species. Alternaria poaceicola is associated with dead stems of Dactylis glomerata L., while A. arbusti and A. oregonensis were reported on Pyrus pyrifolia (Burm.) Nak. and Triticum aestivum L. respectively (Simmons 1993).

Comoclathris Clem., Gen. fung. (Minneapolis): 37 (1909)

Comoclathris was introduced by Clements (1909) and typified by Comoclathris lanata Clem. The genus was referred to Diademaceae (Shoemaker \& Babcock 1992), but currently accepted in Pleosporaceae. However, molecular data for C. lanata are not available (Ariyawansa et al. 2015b).

Comoclathris arrhenatheri Thambugala, Camporesi \& K.D. Hyde, sp. nov.

Fig. 51

Index Fungorum number: IF552097, Facesoffungi number: FoF 03230

Etymology - Named after Arrhenatherum, the host genus from which the holotype was collected.

Holotype - MFLU 16-2583

Saprobic on Arrhenatherum elatius (L.) P.Beauv. ex J.Presl \& C. Presl. Sexual morph: Ascomata 100-150 diameter $\times 80-120 \mu \mathrm{m}$ high $(\bar{x}=128 \times 98 \mu \mathrm{m}, \mathrm{n}=5)$, solitary, scattered or aggregated in small groups, immersed to erumpent, black, elongate, subglobose, covered with pale to dark brown setae, without a distinct ostiole. Peridium 10-20 $\mu$ m wide, comprising few layers of dark brown to black, thick-walled, cells of textura angularis; becoming thin-walled and hyaline towards the inner region. Hamathecium comprising 1-2 $\mu \mathrm{m}$ wide, filiform, septate, rarely branched pseudoparaphyses, embedded in a gelatinous matrix, extending above the asci. Asci (60-)70-95 $\times$ 18.5-25 $\mu \mathrm{m}(\bar{x}=82 \times 22 \mu \mathrm{m}, \mathrm{n}=25), 8$-spored, bitunicate, fissitunicate, cylindro-clavate, short pedicellate, apically rounded, with an ocular chamber. Ascospores $16.5-22 \times 7.7-10.2 \mu \mathrm{m}(\bar{x}=19$ $\times 9 \mu \mathrm{m}, \mathrm{n}=40), 1-2$-seriate, partially overlapping initially yellowish, 1 -septate, becoming yellow to pale brown and muriform, with 4 transverse septa and 2-3 vertical septa, broadly fusiform, with obtuse ends, smooth-walled, surrounded by a thick mucilaginous sheath. Asexual morph: Undetermined.

Culture characteristics - Ascospores germinating on PDA within $24 \mathrm{~h}$ and germ tubes produced from several cells. Colonies growing on PDA, reaching a diameter of $20 \mathrm{~mm}$ after $24 \mathrm{~d}$ at $25{ }^{\circ} \mathrm{C}$, flat to umbonate, surface velvety, with undulate edge, greenish-olivaceous, dense, slightly irregular to filamentous; reverse black to green olivaceous.

Material examined - ITALY, Province of Forlì-Cesena [FC], Passo delle Forche - Galeata, on dead aerial stems of Arrhenatherum elatius (L.) P.Beauv. ex J.Presl \& C. Presl (Poaceae), 2 April 2014, Erio Camporesi IT 1794-2 (MFLU 16-2583, holotype); ibid. (GZAAS 16-0125, isotype), ex-type living culture MFLUCC 15-0465, ICMP 21426; ibid., Santa Sofia, on dead stems of Dactylis glomerata L. (Poaceae), 29 August 2014, IT 2068 (MFLU 16-2584, paratype), living culture MFLUCC 15-0476 
Notes - In this study, Comoclathris arrhenatheri is introduced as a new species and it is phylogenetically distinct from other Comoclathris species (Fig. 44). In the present phylogenetic analysis, strains of $C$. arrhenatheri grouped with other Comoclathris species forming a distinct clade with $98 \%$ BS support.

Comoclathris italica Tibpromma, Camporesi \& K.D. Hyde, Fungal Diversity 80(1): 170 (2014)

Fig. 52

Saprobic on dead stems of Dactylis glomerata L. and Thalictrum sp. Sexual morph: Ascomata 180-240 $\mu \mathrm{m}$ high, 200-250 $\mu \mathrm{m}$ diameter $(\bar{x}=199.4 \times 217.6 \mu \mathrm{m}, \mathrm{n}=10)$, semiimmersed to erumpent, solitary, scattered, broadly oblong to flattened, dark brown to black, coriaceous, cupulate when dry. Peridium 8-12 $\mu \mathrm{m}$ wide at the base, 15-20 $\mu \mathrm{m}$ wide in sides, comprising 3-4 layers, outer layer heavily pigmented, thin-walled, comprising blackish to dark brown cells of textura angularis, inner layer composed of hyaline, thin-walled cells of textura angularis. Hamathecium comprising numerous, $2.5-3 \mu \mathrm{m}(\mathrm{n}=30)$ wide, filamentous, branched, septate, pseudoparaphyses. Asci 100-120 × 30-35 $\mu \mathrm{m}(\bar{x}=111.3 \times 33.1 \mu \mathrm{m}, \mathrm{n}=40)$, 8-spored, bitunicate, fissitunicate, clavate, short pedicellate, thick-walled at the apex, with a minute ocular chamber. Ascospores 30-35 × 10-15 $\mu \mathrm{m}(\bar{x}=31.5 \times 12.9 \mu \mathrm{m}, \mathrm{n}=50)$, overlapping 1-3-seriate, initially 1-septate and hyaline, becoming brown at maturity, muriform, mostly ellipsoidal, 6-8 transversely septate, with 1-2 vertical septa, constricted at the septa, rounded at the ends, surrounded by a thick, hyaline, mucilaginous sheath. Asexual morph: Undetermined.

Culture characteristics - Colonies on PDA reaching 30-35 mm diameter after $21 \mathrm{~d}$, surface pale brown, spreading with moderate aerial mycelium, and even, smooth margins; reverse dirty buff.

Material examined - ITALY, Province of Forlì-Cesena [FC], near Premilcuore, on dead aerial stem of Dactylis glomerata L. (Poaceae), 27 January 2015, Erio Camporesi IT 2357 (MFLU 16-0243).

Notes - Comoclathris italica Tibpromma et al. was introduced by Hyde et al. (2016) and this is the very first report of $C$. italica reported on Dactylis glomerata L. Morphological characters plus phylogenetic analysis (Fig. 44) confirmed the identity of the present collection of $C$. italica.

Comoclathris permunda (Cooke) E. Müll., Monogr. Biol. Soc. Pakistan 8: 68 (1979) [1978]

Basionym: Sphaeria permunda Cooke, Grevillea 5(no. 35): 111 (1877)

Fig. 53

Facesoffungi number: FoF 03231

Saprobic on dead herbaceous branches. Sexual morph: Ascomata 150-200 $\mu \mathrm{m}$ high, 150-200 $\mu \mathrm{m}$ diameter $(\bar{x}=168.5 \times 160.7 \mu \mathrm{m}, \mathrm{n}=10)$, semi immersed to erumpent, solitary, scattered, broadly oblong to flattened, dark brown to black, coriaceous, cupulate when dry, with brown to reddishbrown, setae. Peridium 8-12 $\mu \mathrm{m}$ wide at the base, 10-15 $\mu \mathrm{m}$ wide in sides, comprising 3-4 layers, outer layer heavily pigmented, thin-walled, comprising blackish to dark brown cells of textura angularis, inner layer composed of hyaline, thin-walled cells of textura angularis. Hamathecium comprising numerous, $2-2.5 \mu \mathrm{m}(\mathrm{n}=30)$ wide, filamentous, branched, septate, pseudoparaphyses. Asci $90-110 \times 19-22 \mu \mathrm{m}(\bar{x}=104.6 \times 20.3 \mu \mathrm{m}, \mathrm{n}=40), 8$-spored, bitunicate, fissitunicate, cylindric-clavate, with a 20-30 $\mu \mathrm{m}$ long pedicel, thick-walled at the apex, with a minute ocular chamber. Ascospores 22-28 $\times 9-12 \mu \mathrm{m}(\bar{x}=25.2 \times 10.1 \mu \mathrm{m}, \mathrm{n}=50)$, overlapping 1-2-seriate, muriform, mostly ellipsoidal, 2-4 transversely septate, with 1-2 vertical septa, constricted at the septa, initially hyaline, becoming golden brown at maturity, rounded at the ends, surrounded by a thick, hyaline, mucilaginous sheath. Asexual morph: Undetermined.

Culture characteristics - Colonies on PDA reaching 30-35 mm diameter in $21 \mathrm{~d}$, surface dirty white, spreading with moderate aerial mycelium, and even, smooth margins; reverse dirty buff.

Material examined - ITALY, Province of Forlì-Cesena [FC], near Balze - Verghereto, on dead aerial stem of Phleum pratense L. (Poaceae), 25 July 2014, Erio Camporesi IT 2013 (MFLU 


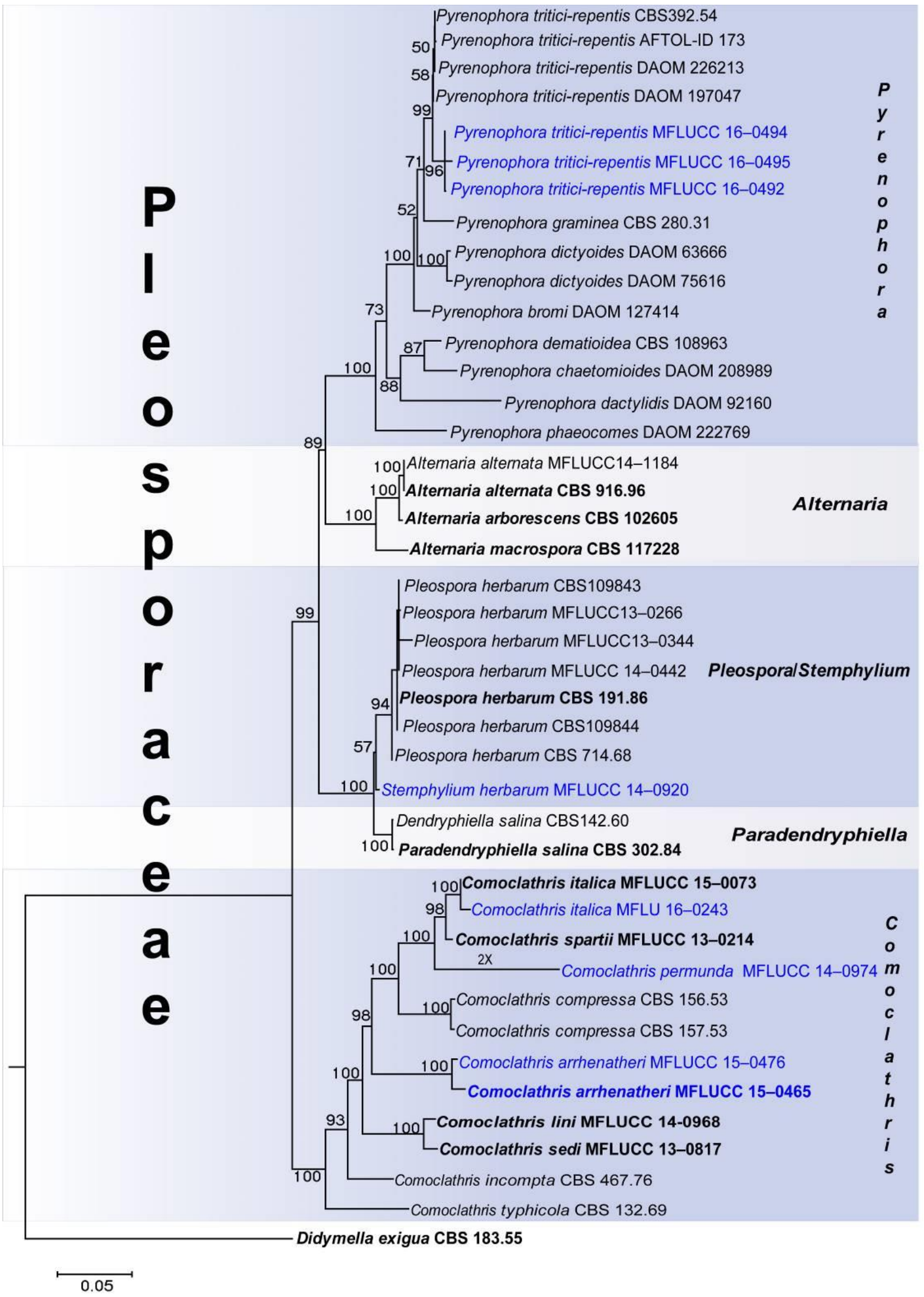

Fig. 44 - Phylogram resulting from maximum likelihood (RAxML) analysis of a combined LSU, SSU, ITS, and RPB2 dataset of selected taxa in Pleosporaceae. Bootstrap support values equal to or greater than $50 \%$ are given above or below the nodes. The ex-type strains are in bold and the new isolates are in blue. The tree is rooted to Didymella exigua. 


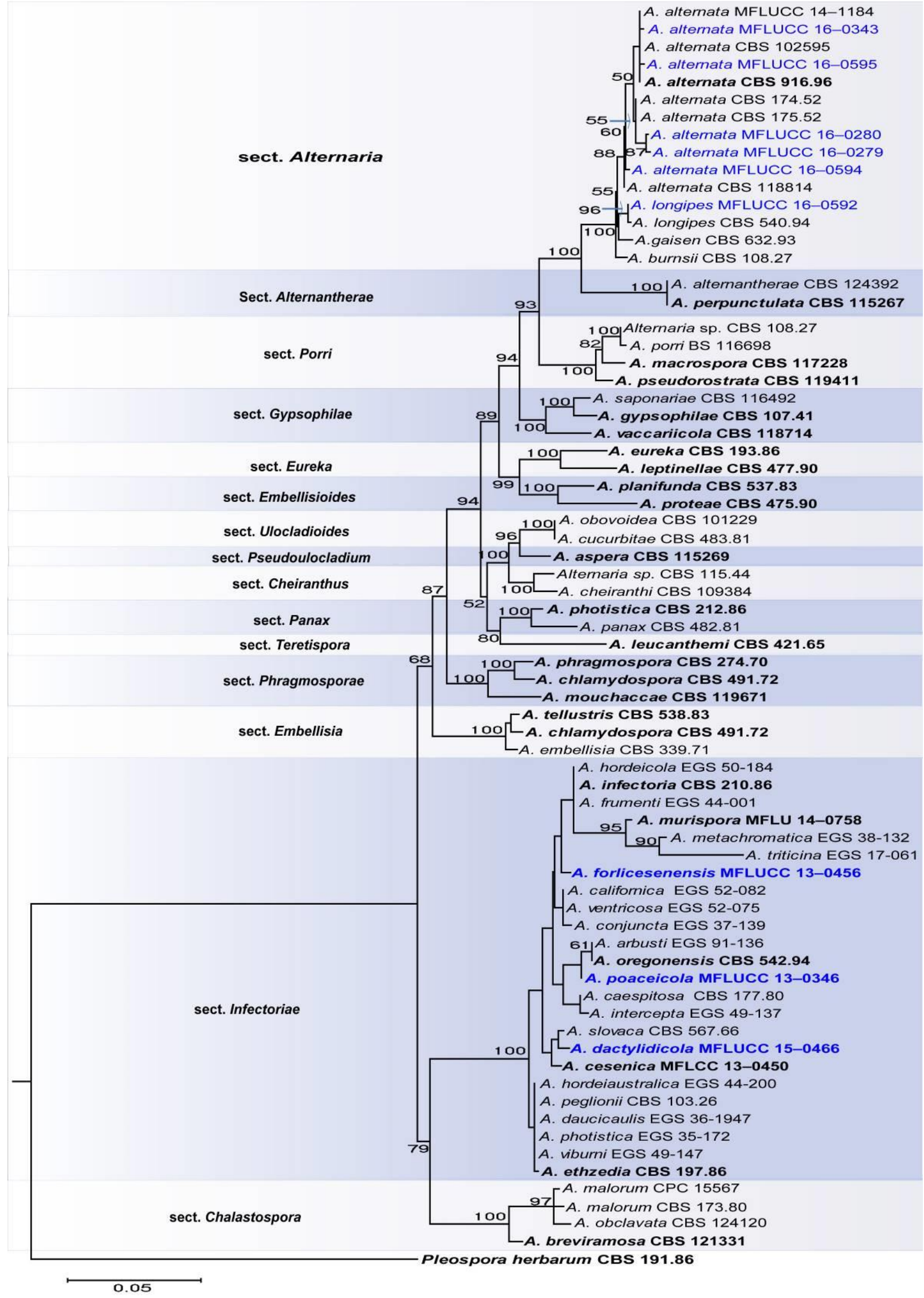

Fig. 45 - Phylogram resulting from maximum likelihood analysis of the combined LSU, ITS, RPB2 and EF1- $\alpha$ sequences of 70 strains representing the Alternaria complex. Maximum likelihood bootstrap support values equal to or greater than $50 \%$ are indicated above or below the nodes. The ex-type strains are in bold and the new isolates are in blue. The tree is rooted to Pleospora herbarum. 


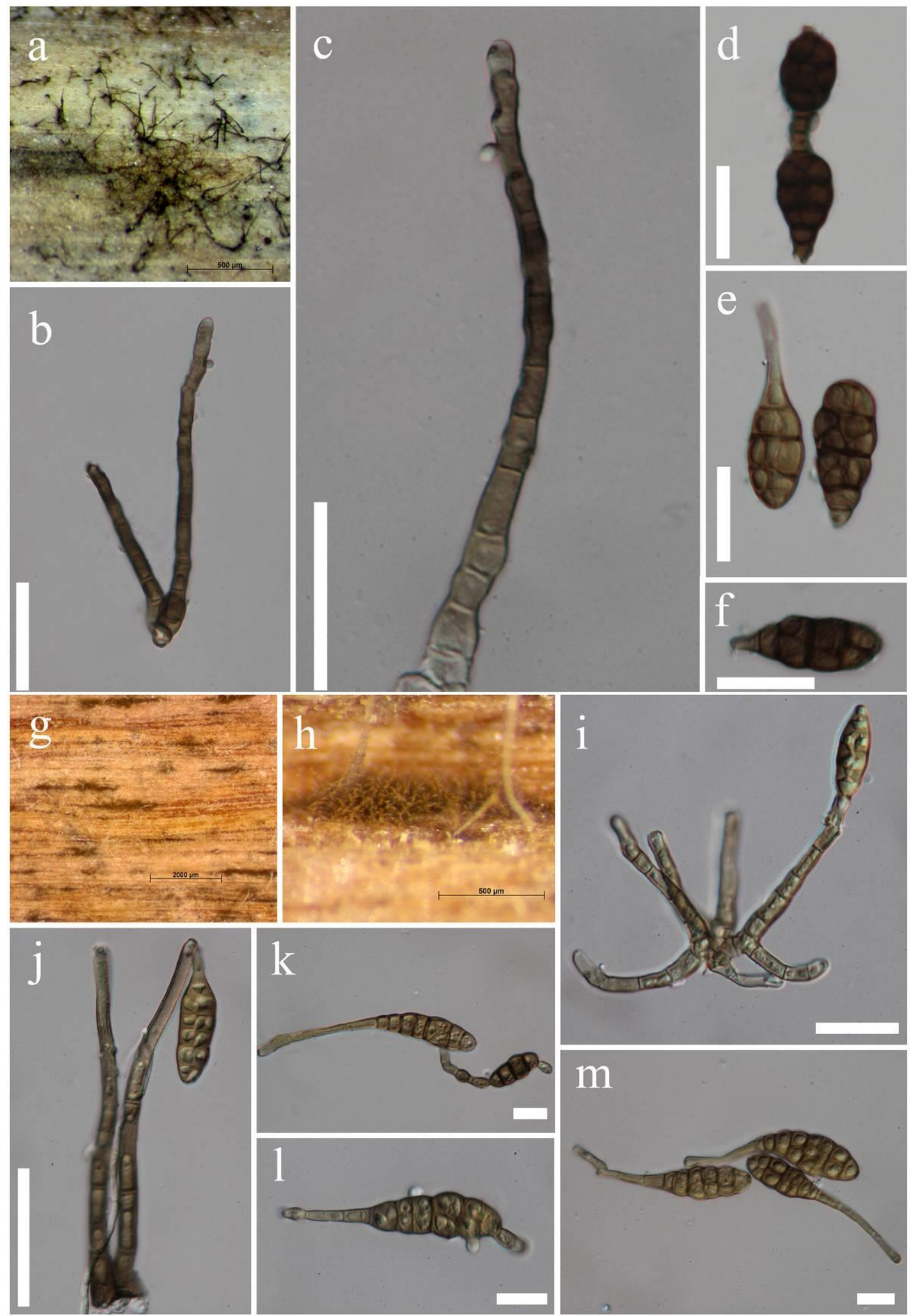

Fig. 46 - Alternaria alternata a-f. on bamboo (MFLU 16-2588). g-m. on Sorghum bicolor (MFLU 16-2591). a, g, h. Appearance of colonies and conidiophores on host surface. b, c, i, j. Conidiophores $d-f, k-m$. Conidia. Scale bars: $b, c=30 \mu \mathrm{m}, d-f=20 \mu \mathrm{m}, \mathrm{i}=25 \mu \mathrm{m}, \mathrm{j}=50 \mu \mathrm{m}, \mathrm{k}-$ $\mathrm{m}=15 \mu \mathrm{m}$. 


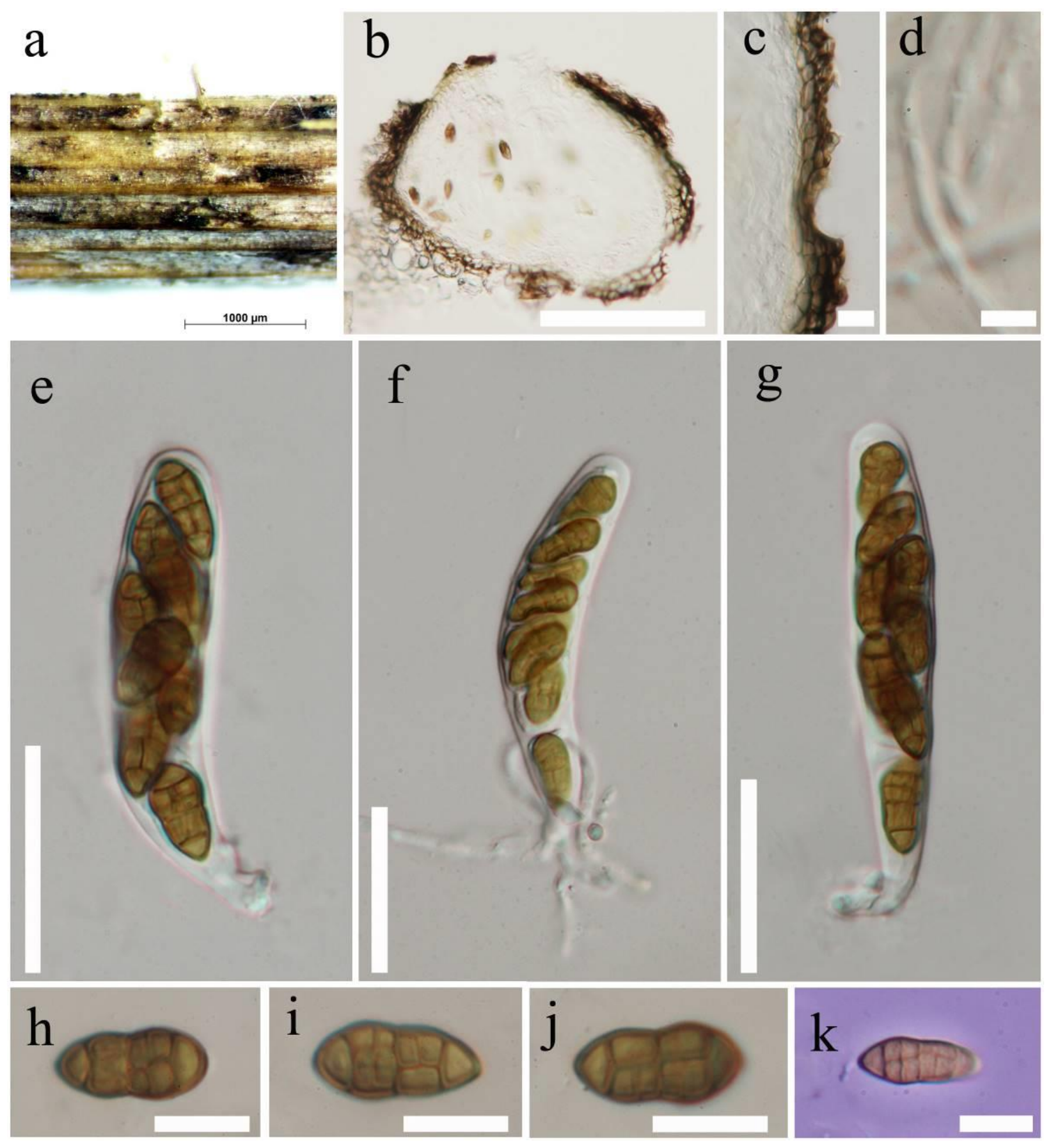

Fig. 47 - Alternaria dactylidicola (MFLU 15-2622, holotype). a. Appearance of ascomata on the host surface. b. Vertical section through ascoma. c. Peridium. d. Pseudoparaphyses. e-g. Asci h-k. Ascospores. Scale bars: $\mathrm{b}=100 \mu \mathrm{m}, \mathrm{c}, \mathrm{h}-\mathrm{k}=10 \mu \mathrm{m}, \mathrm{d}=5 \mu \mathrm{m}, \mathrm{e}-\mathrm{g}=30 \mu \mathrm{m}$.

16-0210, GZAAS 16-0156 reference specimen designated here), living culture MFLUCC 140974, ICMP 21561

Notes - Comoclathris permunda (Cooke) E. Müll. was introduced by Müller (1977) and the taxon was reported on different hosts such as soap plant (Chlorogalum sp.), oil flax seed (Linum usitatissimum L.) and Amorpha fruticosa L. in USA (Cooke 1877, Cooke 1983a, Gruzdevienè et al. 2006). We collected a morphologically closely similar species to $C$. permunda (Cooke 1877) in Italy on Phleum pratense L. and designate it as a reference specimen. In the phylogenetic analysis, C. permunda formed a strongly-supported, distinct clade in the genus Comoclathris with $100 \%$ bootstrap support (Fig. 44). 

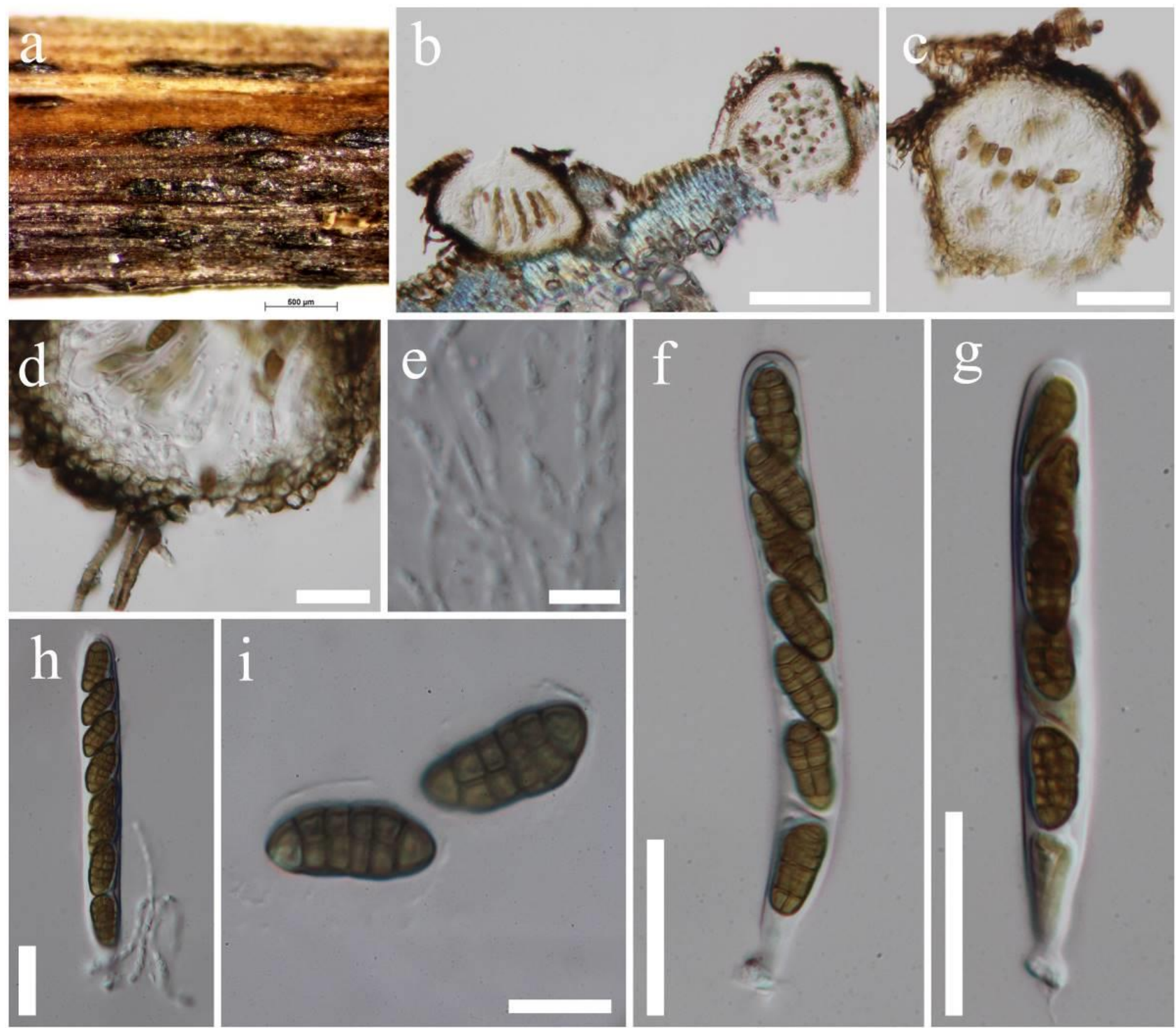

Fig. 48 - Alternaria forlicesenensis (MFLU 15-0560, holotype). a. Appearance of ascomata on the host surface. b, c. Vertical sections through ascomata. d. Peridium and dark brown setae. e. Pseudoparaphyses. f-h. Asci. i. Ascospores. Scale bars: $b=150 \mu \mathrm{m}, \mathrm{c}=50 \mu \mathrm{m}, \mathrm{d}=25 \mu \mathrm{m}, \mathrm{e}, \mathrm{i}=$ $10 \mu \mathrm{m}, \mathrm{f}-\mathrm{h}=30 \mu \mathrm{m}$.

Pleospora Rabenh. ex Ces. \& De Not., Comm. Soc. crittog. Ital. 1(fasc. 4): 217 (1863)

Members of Pleospora are saprobic or parasitic on stems and leaves in terrestrial or aquatic habitats. The genus is characterized by immersed, erumpent to superficial ascomata, 8-spored, bitunicate, cylindrical to clavate asci and brown to pale brown, muriform ascospores. Stemphylium is the asexual morph of the genus (Ariyawansa et al. 2015b). There are more than 1000 names recorded in Index Fungorum (2017).

Pleospora herbarum (Pers.) Rabenh., Klotzschii Herb. Viv. Mycol.: no. 547 (1854)

Fig. 54

Basionym: Sphaeria herbarum Pers., Syn. meth. Fung. (Göttingen) 1: 78 (1801)

= Stemphylium herbarum E.G. Simmons, Sydowia 38: 291 (1986) [1985]

Saprobic or parasitic on stems and leaves. Sexual morph: See Ariyawansa et al. (2015b) and Thambugala et al. (2017). Asexual morph: Hyphomycetous. Conidiophores 40-100 $\times 3.5-5(\bar{x}=$ $69.5 \times 4.19 \mu \mathrm{m})$, macronematous, mononematous, scattered or caespitose, unbranched or branched, straight or flexuous, septate, usually nodose, with a number of vesicular swellings, pale to olivaceous brown, smooth or in part verruculose. Conidiogenous cells holoblastic, integrated, 


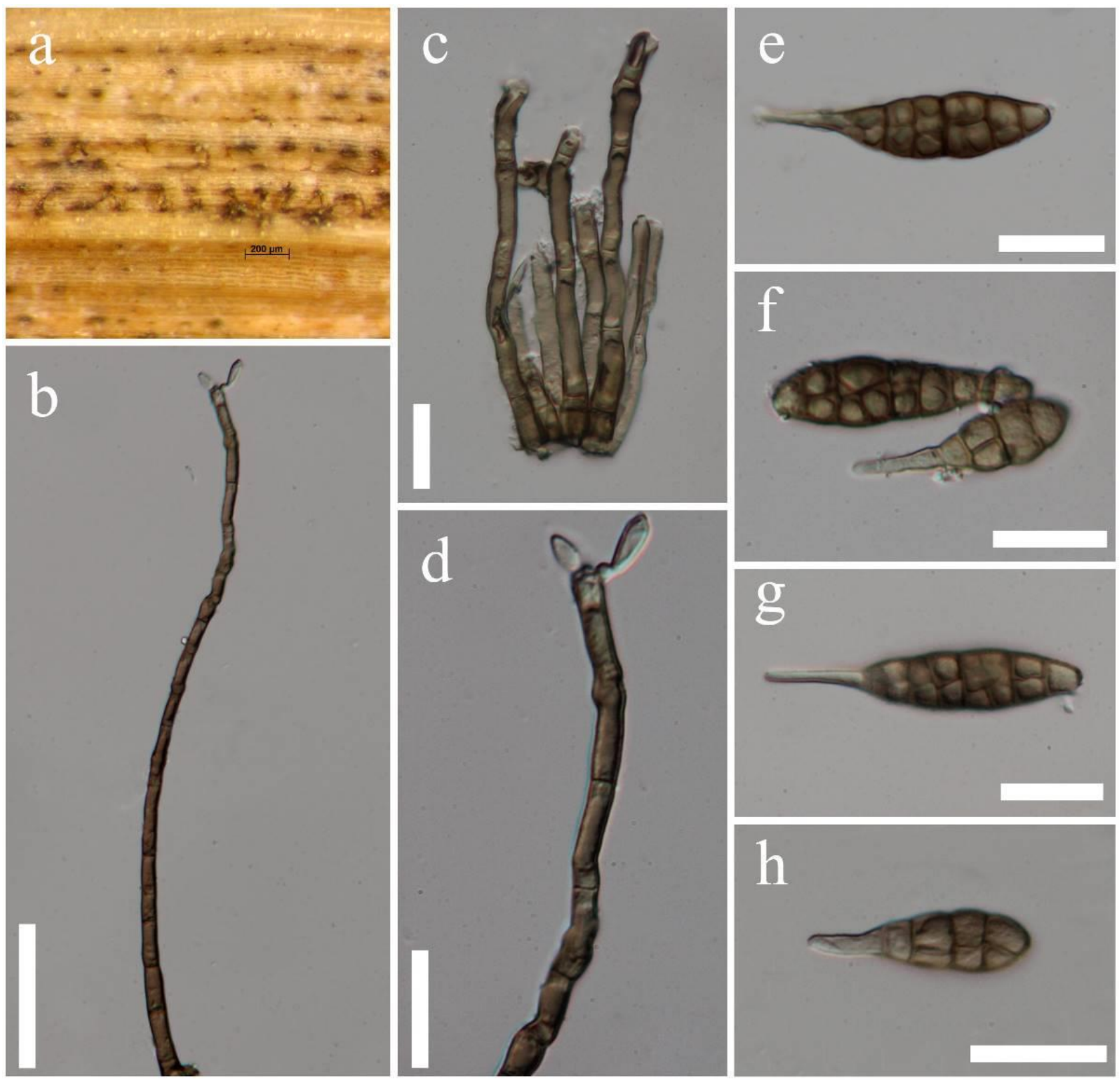

Fig. 49 - Alternaria longipes (MFLU 16-2595). a. Appearance of conidiophores on host surface. b, c. Conidiophores. d. Developing conidia. e-h. Conidia. Scale bars: $b=50 \mu \mathrm{m}, \mathrm{c}-\mathrm{h}=20 \mu \mathrm{m}$.

terminal, percurrent, at first clavate or subsphaerical with thin wall at the apex. Conidia 15-25 $\times$ 10-15 $\mu \mathrm{m}(\bar{x}=20.2 \times 12.9 \mu \mathrm{m}, \mathrm{n}=20)$, solitary, acrogenous, oblong, rounded at the ends, ellipsoidal, obclavate or subsphaerical, dark brown to olivaceous brown, verrucose or echinulate, muriform, often constricted at one or more of the septa.

Culture characteristics - Colonies on PDA reaching $20 \mathrm{~mm}$ diameter after $21 \mathrm{~d}$ at $16{ }^{\circ} \mathrm{C}$, flat, surface smooth, with entire to slightly undulate edge, white at first, greenish grey to dirty white after 6 weeks, pale white near the margin, moderately dense, circular; reverse dirty green. Hyphae septate branched, hyaline, thin, with chlamydospores, sporulating after 8 weeks.

Material examined - ITALY, Province of Forlì-Cesena [FC], Fiumicello - Premilcuore, on dead aerial stem of Lolium sp. (Poaceae), 6 May 2014, Erio Camporesi IT 682 (MFLU 16-0111), living culture, MFLUCC 14-0920.

Notes - Stemphylium herbarum is the sexual morph of Pleospora herbarum E.G. Simmons and associated with a wide range of hosts worldwide (Nene et al. 1996, Woudenberg et al. 2013, Thambugala et al. 2017). Our collection of $S$. herbarum grouped with other strains of $P$. herbarum (Fig. 44) and is phylogenetically and morphologically indistinguishable. 


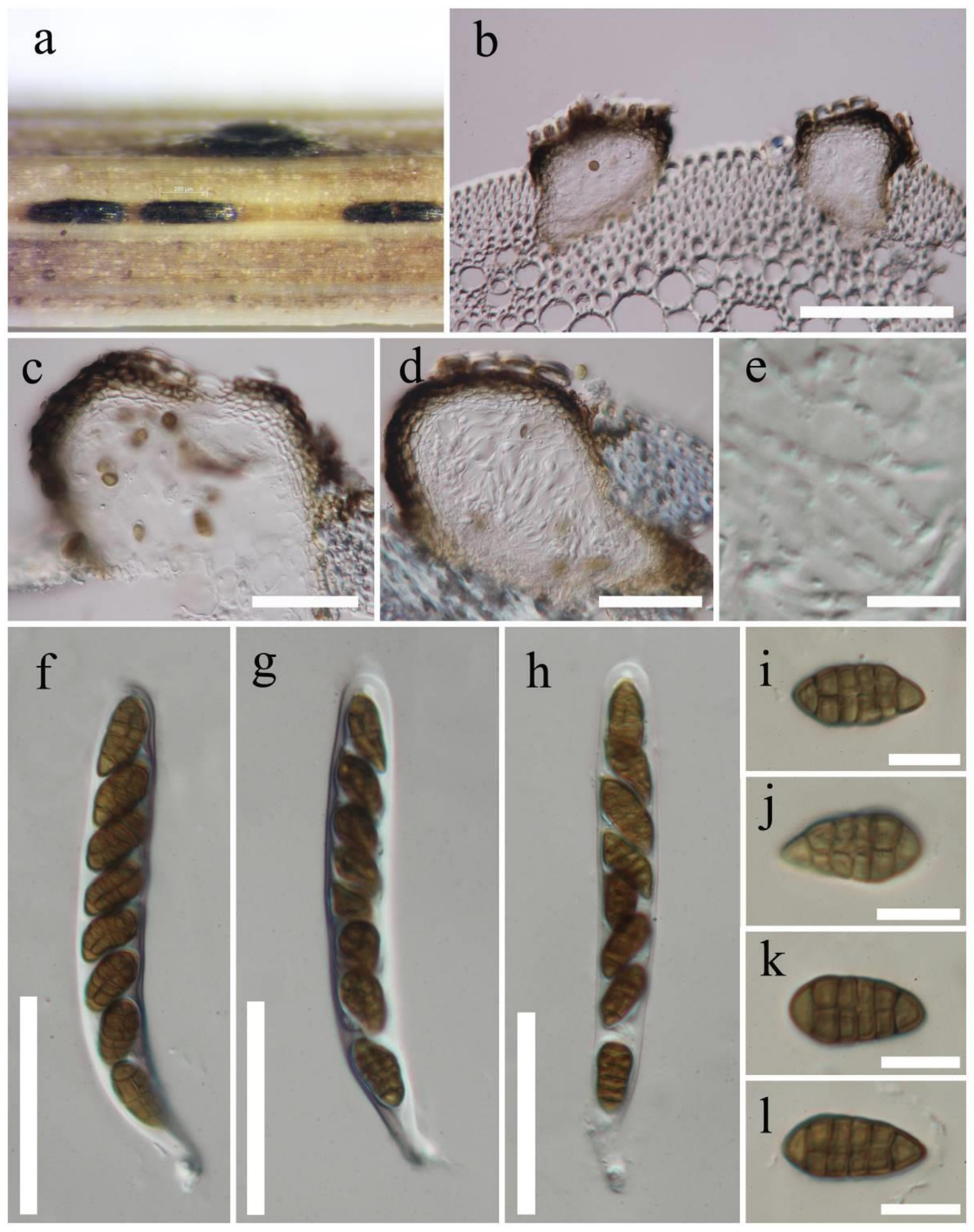

Fig. 50 - Alternaria poaceicola (MFLU 16-2594, holotype). a. Appearance of ascomata on the host surface. b-d. Vertical sections through ascomata. e. Pseudoparaphyses f-h. Asci. i-l. Ascospores. Scale bars: $\mathrm{b}=100 \mu \mathrm{m}, \mathrm{c}, \mathrm{d}=50 \mu \mathrm{m}, \mathrm{e}, \mathrm{i}-\mathrm{l}=10 \mu \mathrm{m}, \mathrm{f}-\mathrm{h}=40 \mu \mathrm{m}$.

Pyrenophora Fr., Summa veg. Scand., Sectio Post. (Stockholm): 397 (1849) = Drechslera S. Ito, Proc. Imp. Acad. Japan 6: 355 (1930) 


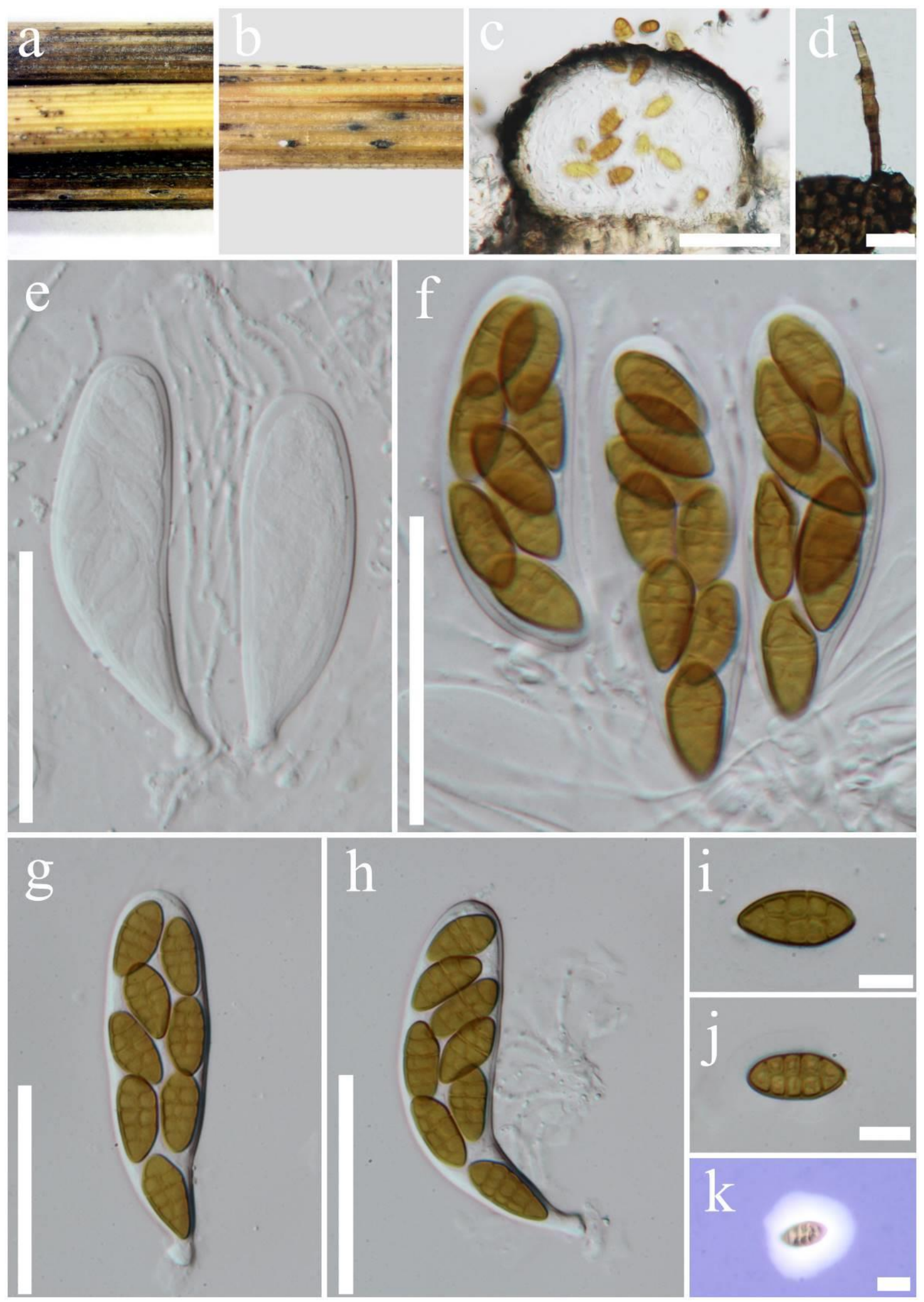

Fig. 51 - Comoclathris arrhenatheri (MFLU 16-2583, holotype). a, b. Appearance of ascomata on the host surface. c. Vertical section through ascomata. d. Dark brown setae e. Immature asci and pseudoparaphyses $\mathrm{f}-\mathrm{h}$. Mature asci $\mathrm{i}-\mathrm{j}$ Ascospores. $\mathrm{k}$. Ascospore stained in Indian ink to reveal the sheath. Scale bars: $\mathrm{c}-\mathrm{h}=50 \mu \mathrm{m}, \mathrm{i}-\mathrm{k}=10 \mu \mathrm{m}$. 


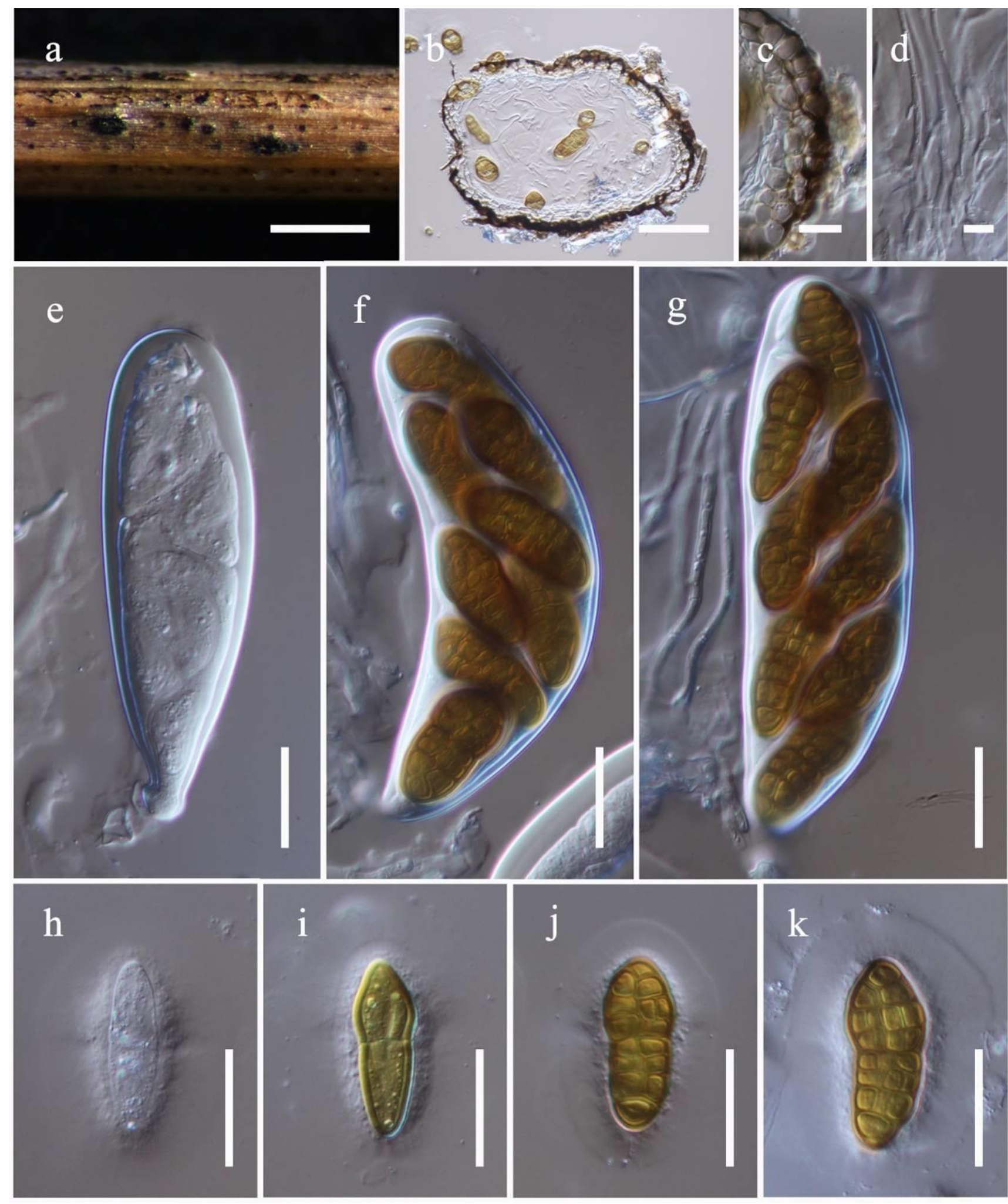

Fig. 52 - Comoclathris italica (MFLU 16-0243). a. Appearance of ascomata on host surface. b. Section of the ascoma. c. Peridium. d. Pseudoparaphyses. e-g. Asci. h-l. Ascospores. Scale bars: a $=500 \mu \mathrm{m}, \mathrm{b}=50 \mu \mathrm{m}, \mathrm{c}, \mathrm{d}=10 \mu \mathrm{m}, \mathrm{e}-\mathrm{k}=20 \mu \mathrm{m}$.

Pyrenophora species cause disease on many graminicolous hosts and some Pyrenophora species have been used as biocontrol agents (Faris et al. 1996, Ariyawansa et al. 2014b). Species have erumpent to near superficial ascomata covered with brown to reddish-brown setae, bitunicate, clavate to sub-cylindrical asci and muriform ascospores surrounded by a mucilaginous sheath. Pyrenophora has been linked to asexual morphs in Drechslera (Ariyawansa et al. 2014b, Ariyawansa et al. 2015b). 
Basionym: Pleospora tritici-repentis Died., Centbl. Bakt. ParasitKde, Abt. I 11: 56 (1903)

Facesoffungi number: FoF 03232

Saprobic on dead stems of grasses. Sexual morph: Ascomata 420-525 diameter $\times 430-510 \mu \mathrm{m}$ high $(\bar{x}=482 \times 472 \mu \mathrm{m}, \mathrm{n}=5)$, solitary or scattered, erumpent to near superficial, globose to subglobose, coriaceous, ostiolate. Ostiole usually broadly papillate, central ostiolar canal filled with periphyses and covered with short, brown to reddish-brown, setae. Peridium 55-135 $\mu \mathrm{m}$ wide, comprising two types of cell layers, outer layer comprising heavily pigmented, thick-walled cells of textura angularis, inner layer composed of 5-7 rows of lightly pigmented to hyaline, thick-walled, cells of textura angularis, becoming thin-walled and flattened towards the inner layers. Hamathecium comprising 2-3 $\mu \mathrm{m}$ wide, filiform, septate, rarely branched pseudoparaphyses. Asci 160-235 × (45-)50-65 $\mu \mathrm{m}(\bar{x}=194 \times 54 \mu \mathrm{m}, \mathrm{n}=15), 8$-spored, bitunicate, fissitunicate, clavate to subcylindrical, with a short, broad pedicel or sessile, thickened and rounded at apex with a distinct ocular chamber surrounded by a large, distinct, apical ring. Ascospores $42-54 \times 16-20.5 \mu \mathrm{m}(\bar{x}=$ $48 \times 18 \mu \mathrm{m}, \mathrm{n}=35$ ), partially overlapping 2 -seriate, ellipsoidal with broadly rounded ends, hyaline to pale brown when immature, becoming yellowish brown when mature, muriform with 3 transverse septa, and 1-2 longitudinal septa, constricted at the septa, smooth-walled, surrounded by a thick mucilaginous sheath. Asexual morph: see notes.

Culture characteristics - Conidia germinating on PDA within $24 \mathrm{~h}$ and germ tubes produced from several cells. Colonies growing on PDA, reaching a diameter of $50 \mathrm{~mm}$ after $7 \mathrm{~d}$ at $25^{\circ} \mathrm{C}$, flat to slightly umbonate, surface smooth to velvety, with filiform edge, greenish olivaceous to brown, moderately dense, circular to filamentous; reverse brown olivaceous to black.

Material examined - RUSSIA, Rostov region, Shakhty city, shore meadow near Grushevsky pond, on dead stems of Poa pratensis L. (Poaceae), 12 May 2015, Timur Bulgakov T-298 (MFLU 16-2585), living culture MFLUCC 16-0494, ICMP 21428; ibid., Solyonaya Balka (Salty gully), on dead stem of Bromus tectorum L., 1 May 2015, Timur Bulgakov, T-210 (MFLU 16-2586), living culture MFLUCC 16-0495, ICMP 21405; ibid., Oktyabrsky District, Persianovsky settlement, on dead stems of Elymus repens (L.) Gould, 28 April 2015, Timur Bulgakov T-211 (MFLU 16-2587), living culture MFLUCC 16-0492.

Notes - Pyrenophora tritici-repentis (Drechslera tritici-repentis (Died.) Shoemaker) is commonly known as the causal agent of tan spot of wheat with a worldwide distribution (Ballance et al. 1989, Lamari \& Bernier 1989) and Pyrenophora has Drechslera asexual morph. In this study, we collected the sexual morph of the fungus on three different graminicolous host (Poa pratensis L., Bromus tectorum L. and Elymus repens (L.) Gould), in Russia.

\section{Roussoellaceae J.K. Liu, R. Phookamsak, D.Q. Dai \& K.D. Hyde, Phytotaxa 181: 7 (2014)}

The family was introduced by Liu et al. (2014) to accommodate Roussoella Sacc., Neoroussoella J.K. Liu et al., and Roussoellopsis I. Hino \& Katum. The members of this family are widely distributed on bamboo and palm hosts and characterized by semi-immersed or immersed ascostromata, forming under darkened, lightly raised, somewhat linear or dome-shaped areas, 4-8spored, bitunicate asci with septate, brown to dark brown ascospores. The asexual morphs of the family are linked to Cytoplea and Melanconiopsis or "neomelanconium"-like species (Liu et al. 2014, Dai et al. 2017).

Roussoella Sacc., in Saccardo \& Paoletti, Atti Inst. Veneto Sci. lett., ed Arti, Sér. 6 6: 410 (1888) Currently 39 species epithets are listed in Index Fungorum (2017) and a new asexual species is described here based on morphological characters and phylogeny.

Roussoella doimaesalongensis Thambugala \& K.D. Hyde, sp. nov. Fig. 57 Index Fungorum number: IF553169, Facesoffungi number: FoF 03233 

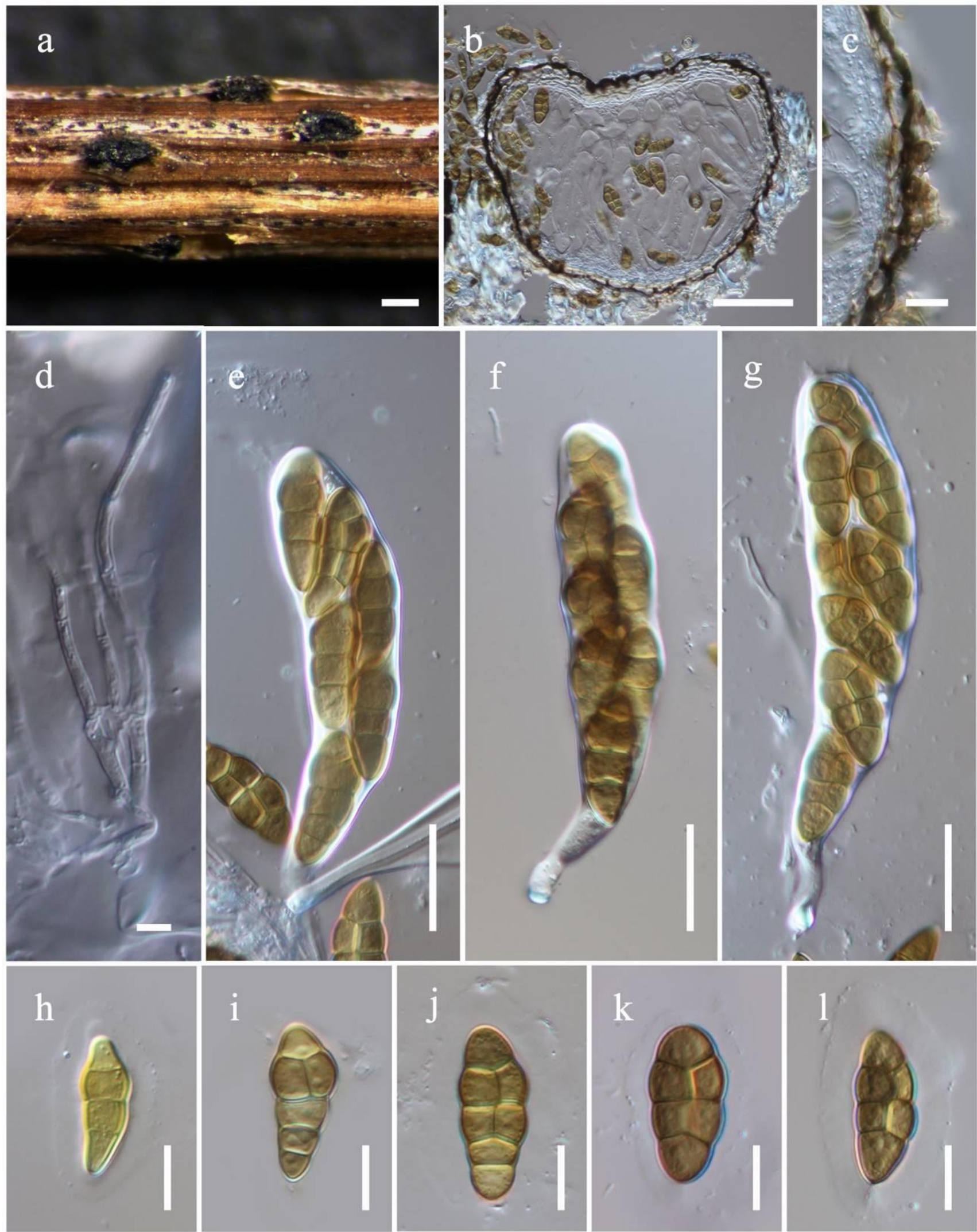

Fig. 53 - Comoclathris permunda (MFLU 16-0210). a. Appearance of ascomata on host surface. b. Vertical section through ascoma. c. Section of the peridium cells. d. Pseudoparaphyses. e-g. Asci $\mathrm{h}-1$. Ascospores. Scale bars: $\mathrm{a}=200 \mu \mathrm{m}, \mathrm{b}=50 \mu \mathrm{m}, \mathrm{c}=10 \mu \mathrm{m}, \mathrm{d}=5 \mu \mathrm{m}, \mathrm{e}-\mathrm{g}=20 \mu \mathrm{m}, \mathrm{h}-\mathrm{l}=10$ $\mu \mathrm{m}$. 


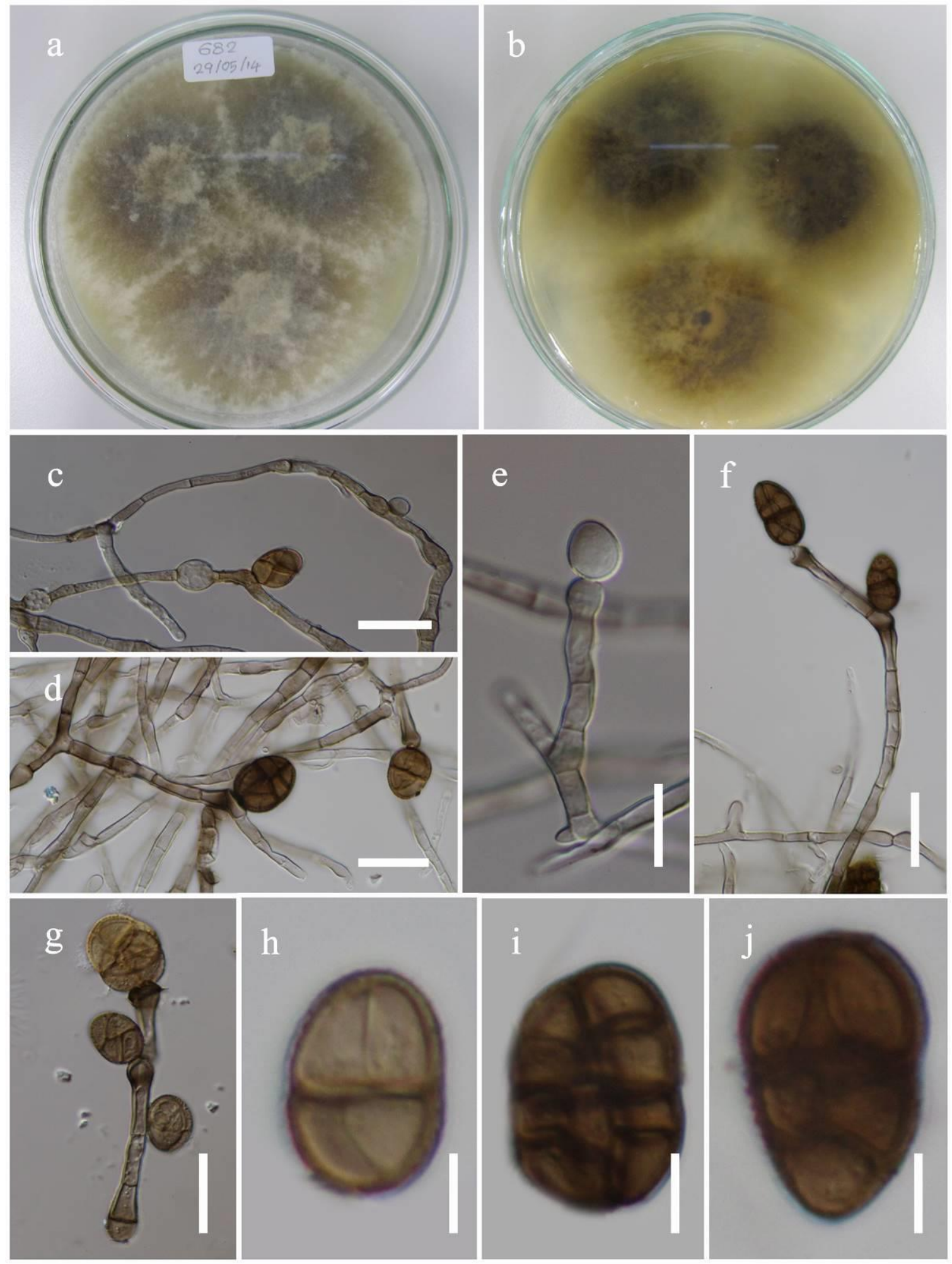

Fig. 54 - Pleospora herbarum/ Stemphylium herbarum (from MFLUCC 14-0920). a, b. Colonies on PDA. c-g. Conidiophores and developing conidia. $\mathrm{h}-\mathrm{j}$. Conidia. Scale bars: $\mathrm{c}-\mathrm{g}=20 \mu \mathrm{m}, \mathrm{h}-\mathrm{j}=$ $5 \mu \mathrm{m}$.

Etymology - Referring to the region Doi Mae Salong (Thailand), where the species was encountered.

Holotype - MFLU 16-2596 

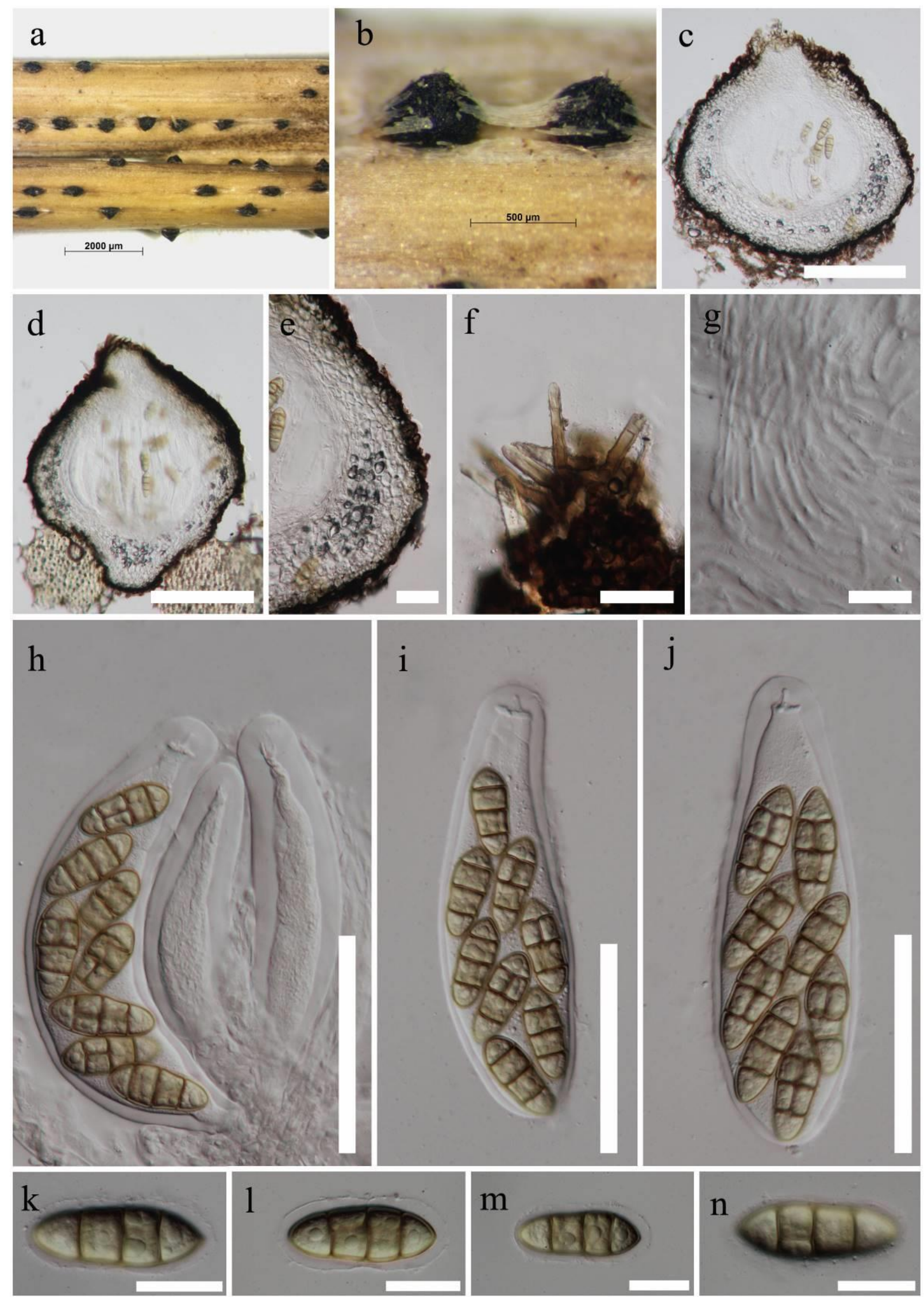

Fig. 55 - Pyrenophora tritici-repentis (MFLU 16-2585). a, b. Appearance of ascomata on the host surface. c, d. Vertical sections through ascomata. e. Peridium f. Dark brown setae. g. Pseudoparaphyses. $\mathrm{h}-\mathrm{j}$. Mature and immature asci. $\mathrm{k}-\mathrm{n}$. Ascospores. Scale bars: $\mathrm{c}, \mathrm{d}=200 \mu \mathrm{m}, \mathrm{e}, \mathrm{f}$ $=50 \mu \mathrm{m}, \mathrm{g}=20 \mu \mathrm{m}, \mathrm{h}-\mathrm{j}=100 \mu \mathrm{m}, \mathrm{k}-\mathrm{n}=25 \mu \mathrm{m}$. 
Saprobic on decaying bamboo culms. Sexual morph: Undetermined. Asexual morph: Conidiomata 95-175 $\mu \mathrm{m}$ diameter $\times 90-175 \mu \mathrm{m}$ high $(\bar{x}=127 \times 128 \mu \mathrm{m}, \mathrm{n}=20)$, superficial on toothpick in culture, pycnidial, globose to subglobose, scattered or gregarious, ostiolate. Conidiomatal wall up to $20 \mu \mathrm{m}$ wide, composed of 4-5 layers of cells of lightly pigmented to dark brown cells of textura angularis. Conidiophores reduced to conidiogenous cells. Conidiogenous cells 3.2-4.6 $\times 3.2-5.3 \mu \mathrm{m}(\bar{x}=3.5 \times 4.3 \mu \mathrm{m}, \mathrm{n}=15)$, lining the inner wall layer of the pycnidium, holoblastic, subcylindrical to ampulliform, hyaline, smooth. Conidia (2-)3-4.4(-5.6) $\times 1.6-2.5 \mu \mathrm{m}$ $(\bar{x}=3.6 \times 2 \mu \mathrm{m}, \mathrm{n}=50)$, subglobose to oblong or ellipsoidal, initially hyaline, becoming light brown to yellowish brown, aseptate with two guttules, smooth-walled.

Culture characteristics - Conidia germinating on PDA within $18 \mathrm{~h}$. Colonies growing on PDA, reaching a diameter of $23 \mathrm{~mm}$ after $7 \mathrm{~d}$ at $25{ }^{\circ} \mathrm{C}$, flat to slightly umbonate, surface velvety, with entire edge, grey, white near the margin, dense, circular; reverse grayish black.

Material examined - THAILAND, Chiang Rai Province, Doi Mae Salong, on dead Bamboo branches, 17 July 2014, K.M. Thambugala KM 015 (MFLU 16-2596, holotype); ibid. (GZAAS 16-0127, isotype), ex-type living culture MFLUCC 14-0584, ICMP 21416.

Notes - Roussoella doimaesalongensis is described here as a new species from dead bamboo branches. Only the asexual morph is known for Roussoella doimaesalongensis. This species shows the typical morphological characters of the asexual morphs of Roussoella species (Liu et al. 2014, Dai et al. 2017), while the results of the present phylogenetic analysis (Fig. 56) provide robust evidence that $R$. doimaesalongensis is a new species.

Roussoella scabrispora (Höhn.) Aptroot, Nova Hedwigia 60: 368.1995

Fig. 58

$\equiv$ Didymosphaeria scabrispora Höhn., Sber. Akad. Wiss. Wien, Math. Nat 118: 1501. 1909

Facesoffungi number: FoF 03234

Saprobic on decaying bamboo culms or palms branches. Sexual morph: Ascostromata 2-2.5 $\mathrm{mm}$ diameter, solitary to gregarious, immersed under a clypeus, black, partially erumpent, uniloculate, carbonaceous. Locules subglobose to conical, with a flattened base, ostiolate. Peridium up to $15 \mu \mathrm{m}$ wide, composed of dark brown to lightly pigmented cells of textura angularis to textura prismatica, fusing at the outside with the host cells. Hamathecium comprising 1-2 $\mu \mathrm{m}$ wide, numerous, anastomosing, aseptate, cellular pseudoparaphyses, embedded in a gelatinous matrix. Asci $(150-) 180-215(-230) \times 10.5-12.5 \mu \mathrm{m}(\bar{x}=197 \times 11.2 \mu \mathrm{m}, \mathrm{n}=20)$, 8-spored, bitunicate, cylindrical, with a short knob-like pedicel, apically rounded with an ocular chamber. Ascospores $25-33 \times 7-10 \mu \mathrm{m}(\bar{x}=28 \times 8.4 \mu \mathrm{m}, \mathrm{n}=35)$, partially overlapping 1-seriate, ellipsoid to broad fusiform, with rounded ends, 2-celled, constricted at the septum, with a reticulate spore wall ornamentation. Asexual morph: Undetermined.

Culture characteristics - Conidia germinating on PDA within $18 \mathrm{~h}$ and germ tubes produced from one or both cells. Colonies growing on PDA, reaching a diameter of $25 \mathrm{~mm}$ after $7 \mathrm{~d}$ at $25^{\circ} \mathrm{C}$, flat to slightly umbonate, surface smooth to velvety, with entire to slightly undulate edge, white to grey, moderately dense, circular to filamentous; reverse olivaceous grey to black.

Material examined - THAILAND, Chiang Rai Province, Doi Mae Salong, on dead Bamboo culms, 17 July 2014, K.M. Thambugala KM 010 (MFLU 16-2597), living culture MFLUCC 140582, ICMP 21406.

Notes - Roussoella scabrispora is a bamboo-inhabiting ascomycete widely distributed in Asia (Hyde et al. 1997, Höhnel 1909, Liu et al. 2014). This could possibly be a species of Roussoellopsis and no asexual morph has been reported so far (Liu et al. 2014).

Sporormiaceae Munk, Dansk bot. Ark. 17(no. 1): 450 (1957)

The members of the family Sporormiaceae are mainly saprobic on dung, plant debris, soil and wood. Presently, nine genera are accepted in the family (Hyde et al. 2013, Phukhamsakda et al. 2016).

Sparticola Phukhams., Ariyaw., Camporesi \& K.D. Hyde, in Phukhamsakda et al., Cryptog. Mycol. 37(1): 84 (2016). 


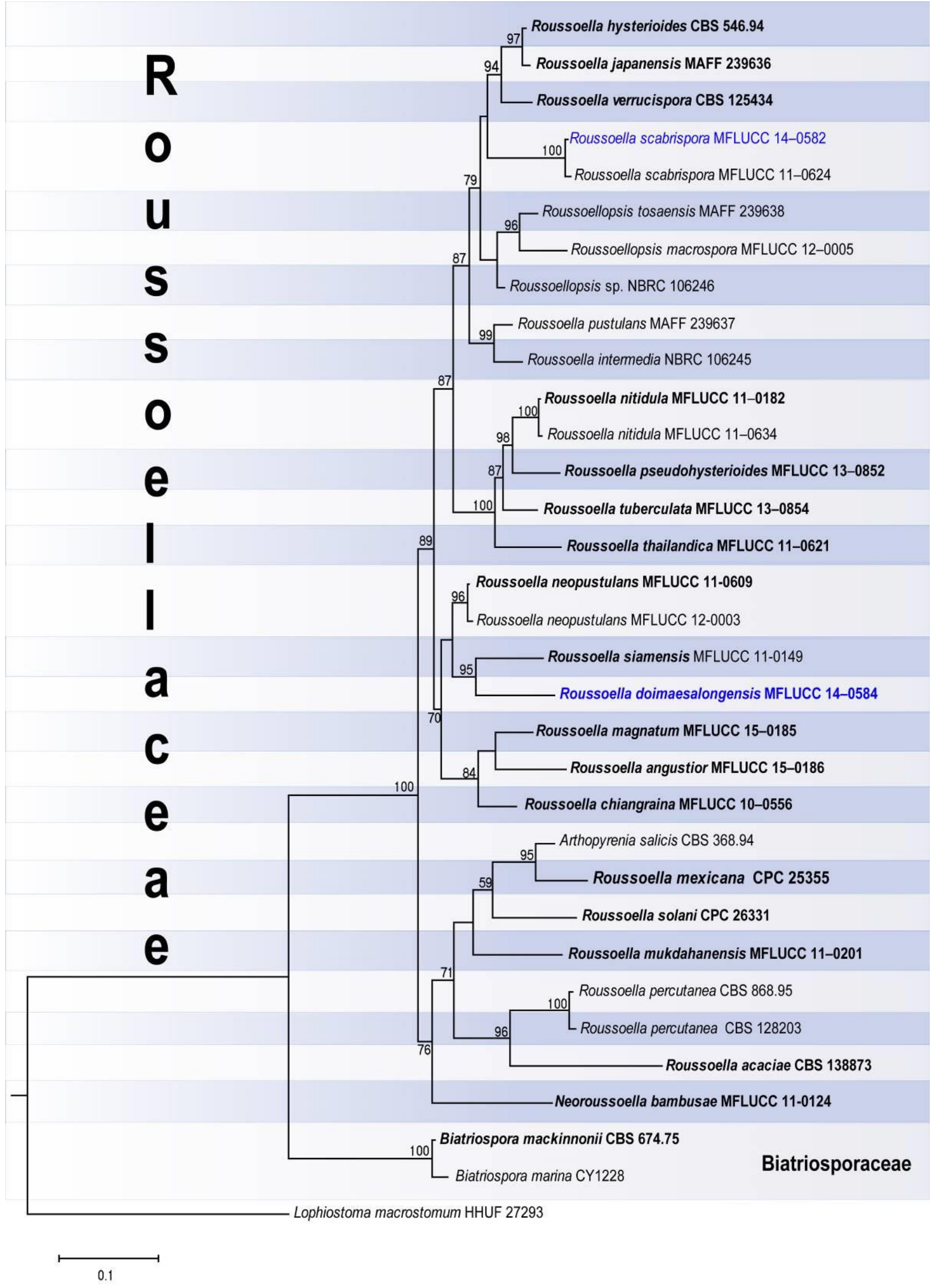

Fig. 56 - Phylogram resulting from maximum likelihood (RAxML) analysis of a combined LSU, ITS, EF1- $\alpha$ and RPB2 dataset of Roussoellaceae and Biatriosporaceae. Bootstrap support values equal to or greater than $50 \%$ are given above or below the nodes. The ex-type strains are in bold and the new isolates are in blue. The tree is rooted to Lophiostoma macrostomum. 

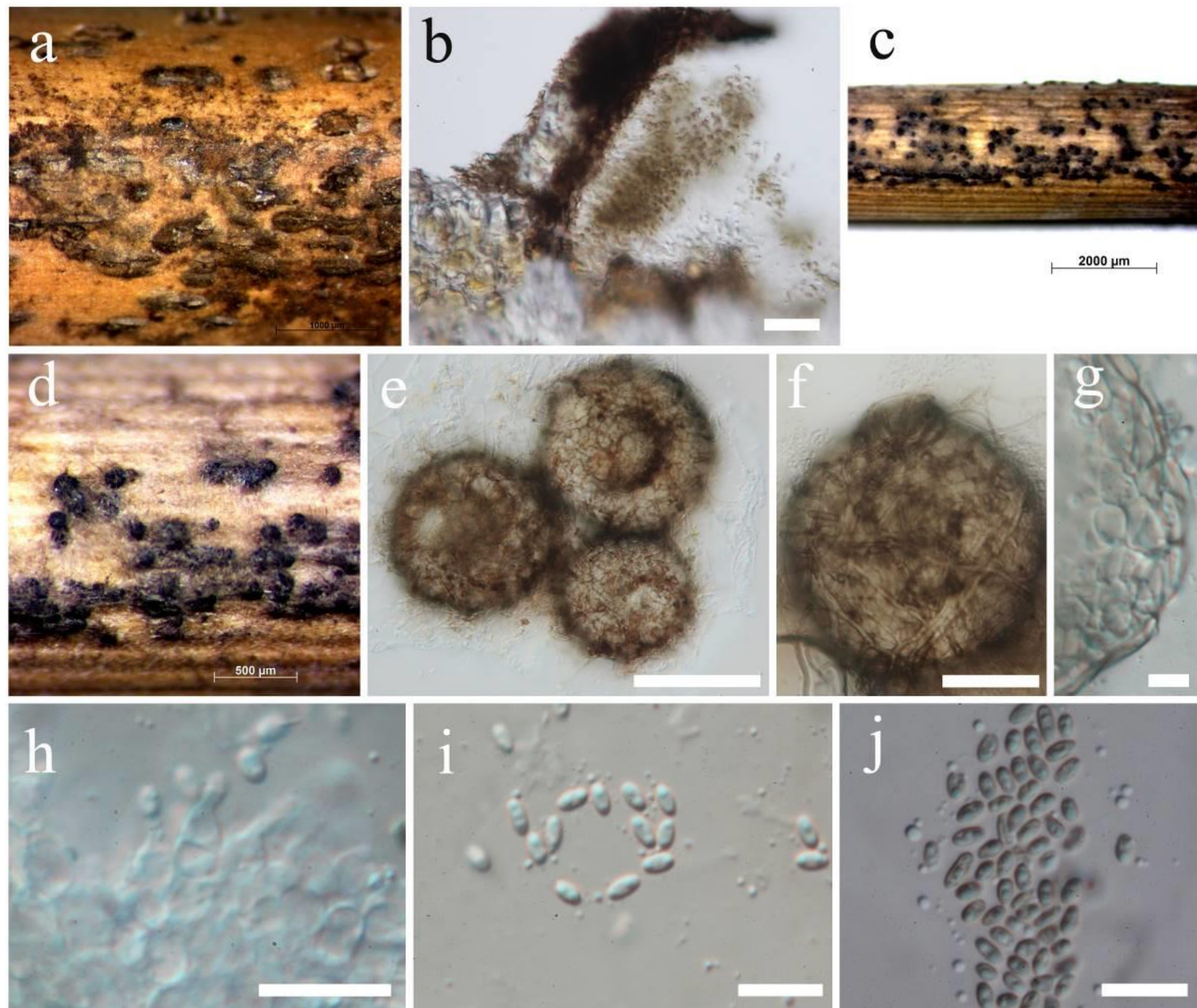

Fig. 57 - Roussoella doimaesalongensis (MFLU 16-2596, holotype). a. Appearance of conidiomatal on host surface b. Conidiomata wall. c, d Conidiomata formed on a toothpick. e, f. Squash mount of conidiomata. g. Conidiomatal wall. h. Conidiogenous cells and developing conidia. i, j. Conidia. Scale bars: $\mathrm{b}=20 \mu \mathrm{m}, \mathrm{e}=100 \mu \mathrm{m}, \mathrm{f}=50 \mu \mathrm{m} \mathrm{g}=5 \mu \mathrm{m}, \mathrm{h}-\mathrm{j}=10 \mu \mathrm{m}$.

Sparticola was introduced by Phukhamsakda et al. (2016) to accommodate three ascomycetous fungal species occurring on Spartium junceum L. (Fabaceae). The genus is characterized by immersed, ostiolate ascomata, 8-spored, bitunicate, short pedicellate asci, yellowish, 3-transversely septate ascospores and hyphomycetous asexual morph with dictyosporous, coiled, involute, brown conidia.

Sparticola junci Phukhamsakda, Camporesi \& K.D. Hyde, in Phukhamsakda et al., Cryptog. Mycol. 37(1): 87 (2016)

Fig. 60

Saprobic on dead Spartium junceum L. and Anthoxanthum odoratum L. Sexual morph: Ascomata 150-220 $\mu \mathrm{m}$ high, $150-200 \mu \mathrm{m}$ diameter $(\bar{x}=180.4 \times 172.9 \mu \mathrm{m}, \mathrm{n}=10)$, immersed to semi-erumpent, solitary, scattered, globose to subglobose, dark brown to black, coriaceous. Peridium 8-12 $\mu \mathrm{m}$ wide at the base, 15-20 $\mu \mathrm{m}$ wide in sides, comprising 3-4 layers, outer layer heavily pigmented, thin-walled, comprising blackish to dark brown cells of textura angularis, inner layer composed of hyaline, thin-walled cells of textura angularis. Hamathecium comprising numerous, $2.5-3 \mu \mathrm{m}(\mathrm{n}=30)$ wide, filamentous, branched, septate, pseudoparaphyses. Asci 110$130 \times 20-25 \mu \mathrm{m}(\bar{x}=117.6 \times 22.8 \mu \mathrm{m}, \mathrm{n}=40), 8$-spored, bitunicate, fissitunicate, cylindrical to cylindric-clavate, short pedicellate, thick-walled at the apex, with a minute ocular chamber. Ascospores $22-24 \times 9-11 \mu \mathrm{m}(\bar{x}=23.1 \times 9.9 \mu \mathrm{m}, \mathrm{n}=50)$, overlapping 2-seriate, fusiform, 
ellipsoidal, 2-3 septate, slightly constricted at the septa, initially hyaline, becoming golden brown at maturity, pointed at upper end and rounded at the lower end, surrounded by a thick, hyaline, mucilaginous sheath. Asexual morph: See Phukhamsakda et al. (2016).

Culture characteristics - Colonies on PDA reaching 30-35 mm diameter after $21 \mathrm{~d}$, greenish grey centre and dark brown periphery, spreading with moderate aerial mycelium, and even, smooth margins; reverse dirty blackish brown.

Material examined - ITALY, Province of Forlì-Cesena [FC], on dead aerial stem of Anthoxanthum odoratum L. (Poaceae), 27 January 2015, Erio Camporesi IT 2354 (MFLU 160242)

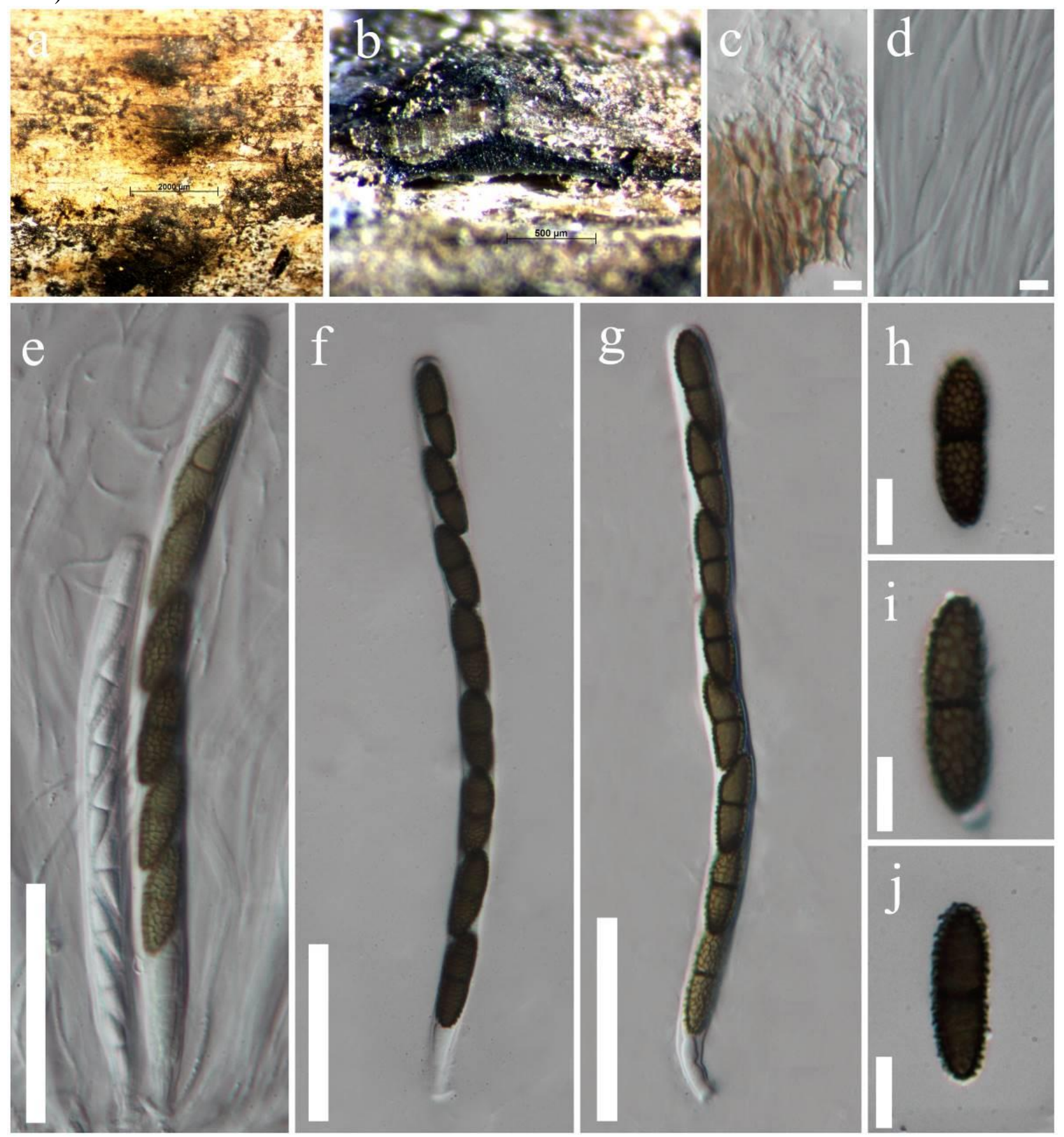

Fig. 58 - Roussoella scabrispora (MFLU 16-2597). a. Ascostromata on a bamboo culm. b. Vertical section through ascostroma. c. Peridium. d. Pseudoparaphyses. e-g. Asci. $\mathrm{h}-\mathrm{j}$. Ascospores with reticulate ornamentation. Scale bars: $\mathrm{c}, \mathrm{d}=5 \mu \mathrm{m}, \mathrm{e}-\mathrm{g}=50 \mu \mathrm{m}, \mathrm{h}-\mathrm{j}=10 \mu \mathrm{m}$. 


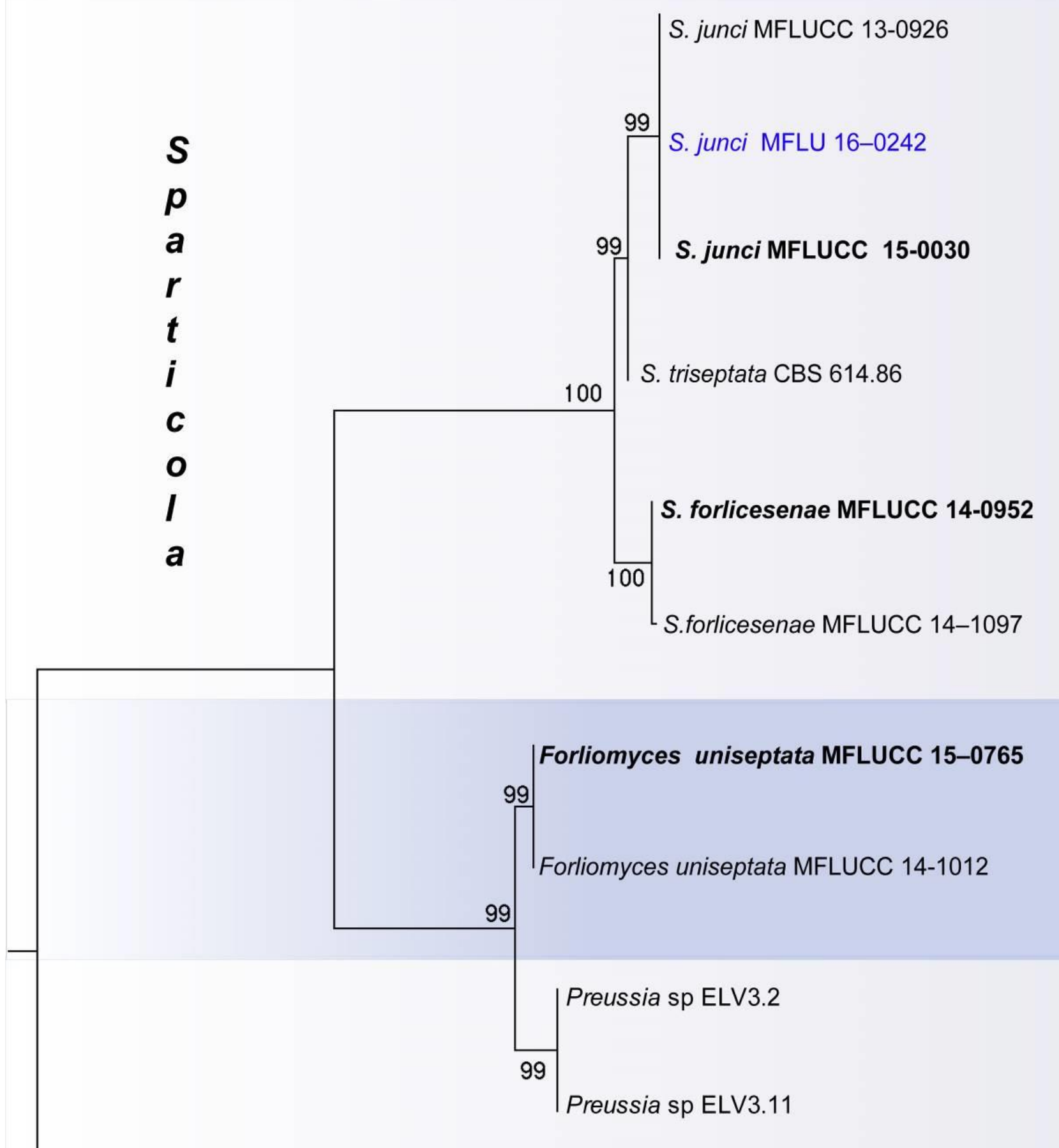

Sporormia fimetaria UPS: Dissing Gr 81-194

\subsection{2}

Fig. 59 - Phylogram resulting from maximum likelihood analysis of the combined LSU and ITS sequences of the genus Sparticola and allied taxa in Sporormiaceae. Maximum likelihood bootstrap support values equal to or greater than $50 \%$ are indicated above or below the nodes. The ex-type strains are in bold and the new isolates are in blue. The tree is rooted to Sporormia fimetaria. 

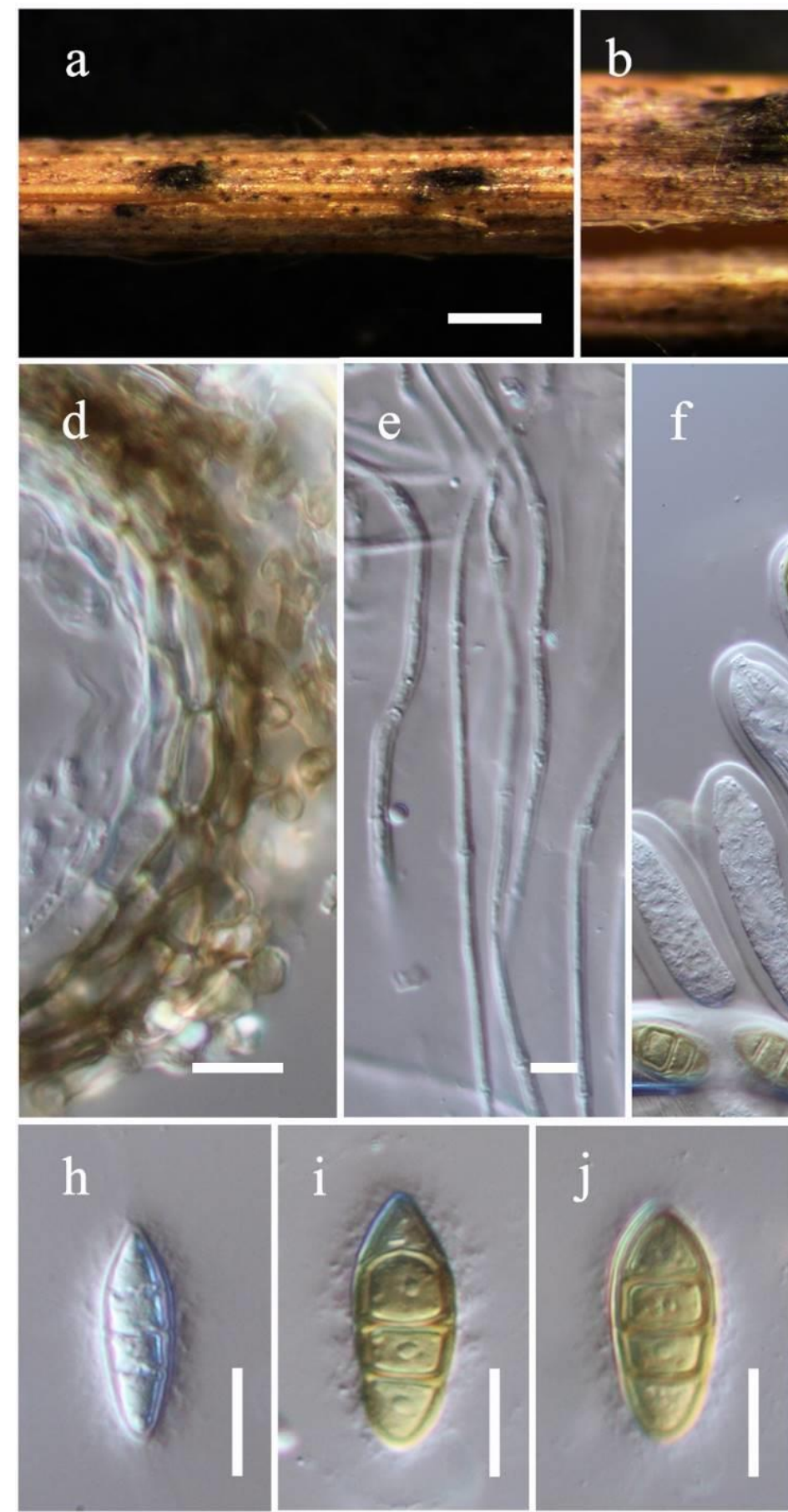
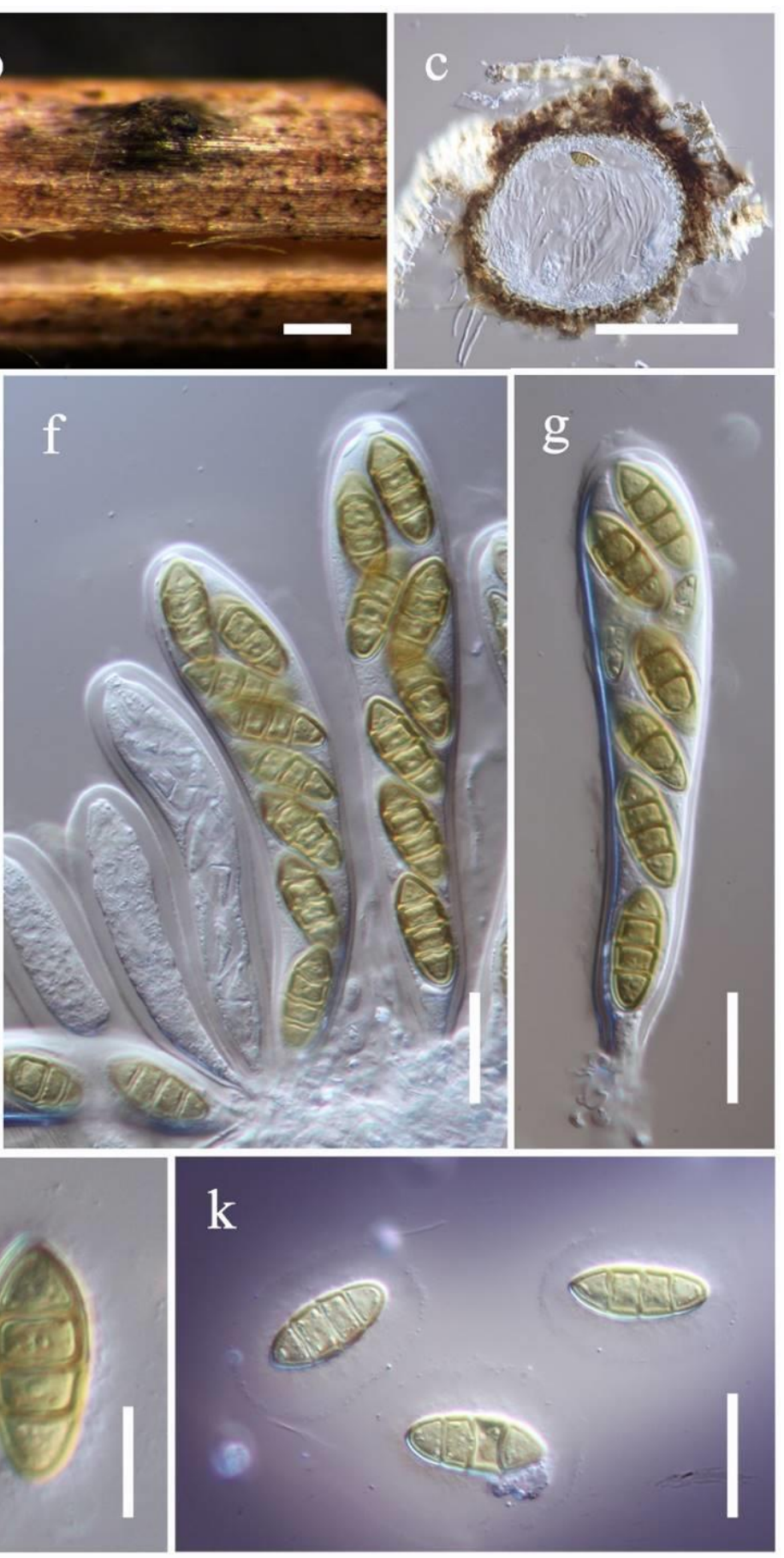

Fig. 60 - Sparticola junci (MFLU 16-0242). a, b. Appearance of ascomata on host substrate. c. Section of the ascoma. d. Peridium. e Pseudoparaphyses. f, g Asci. h-k. Ascospores (note the ascospores stained in Indian ink to show the mucilaginous sheath in $\mathrm{k}$ ). Scale bars: $\mathrm{a}=500 \mu \mathrm{m}, \mathrm{b}=$ $200 \mu \mathrm{m}, \mathrm{c}=100 \mu \mathrm{m}, \mathrm{d}=10 \mu \mathrm{m}, \mathrm{e}=5 \mu \mathrm{m}, \mathrm{f}, \mathrm{g}, \mathrm{k}=20 \mu \mathrm{m}, \mathrm{h}-\mathrm{j}=10 \mu \mathrm{m}$.

Notes - This is the first report of S. junci on a host other than Spartium junceum L. (Fabaceae). Morphological characters and phylogenetic analysis (Fig. 59) confirmed the identity of our specimen of $S$. junci on Anthoxanthum odoratum (Poaceae).

\section{Discussion}

There are numerous dothideomycetous fungal species that occur on a wide range of hosts in Poaceae with a worldwide distribution. In this study, we show the diversity and taxonomy of 50 grass inhabiting fungal species with molecular sequence data and descriptions linked to 
morphological illustrations. We hope this research will stimulate interest in the collection and description of grass fungi.

Most of the members of the family Bambusicolaceae and Phaeosphaeriaceae appear to be grass inhabiting fungi (Quaedvlieg et al. 2013, Phookamsak et al. 2014a, Ariyawansa et al. 2015a, Liu et al. 2015, Hyde et al. 2016, Dai et al. 2017) and nearly $40 \%$ of the species out of the total number of treated taxa in this research belong to these two families. Didymosphaeriaceae, Pleosporaceae, and Roussoellaceae are the other families in Dothideomycetes that include a significant number of grass fungi. However, there are likely to be thousands of Dothideomycetes as well as other fungi belonging to other classes that are associated with grasses worldwide. These taxa need to be recollected, epitypified and sequenced to establish their taxonomic affinities.

\section{Acknowledgements}

The Mushroom Research Foundation, Chiang Rai, Thailand and Guizhou Key Laboratory of Agricultural Biotechnology, Guizhou Academy of Agricultural Sciences, Guiyang, Guizhou Province, People's Republic of China are acknowledged for financial support and providing postgraduate scholarship support to K.M. Thambugala. Kevin D. Hyde thanks the Chinese Academy of Sciences (project number 2013T2S0030) for the award of Visiting Professorship for Senior International Scientists at Kunming Institute of Botany. Rungtiwa Phookamsak expresses sincere appreciations to The CAS President's Internaional Fellowship for Postdoctoral Researchers (project no. 2017PB0072). K.M. Thambugala thanks Prof. D. Jayarama Bhat and Dr. D. S. Manamgoda for helpful comments and advice on the manuscript. Shaun Pennycook is thanked for checking and suggesting corrections to the Latin names. Indunil C. Senanayake, N.I. Silva and Rekhani H. Perera are thanks for providing fresh material for the study. K.M. Thambugala acknowledges Jian Kui Liu and Jin Feng Zhang for their great support in collecting materials in China. Alan JL Phillips acknowledges the support from Biosystems and Integrative Sciences Institute (BioISI,FCT/UID/Multi/04046/2013).

\section{References}

Aime MC. 2006 - Toward resolving family-level relationships in rust fungi (Uredinales). Mycoscience 47, 112-122.

Anikster Y, Wahl I. 1979 - Coevolution of the rust fungi on Gramineae and Liliaceae and their hosts. Annual Review of Phytopathology 17, 367-403.

Ariyawansa HA, Tanaka K, Thambugala KM, Phookamsak R et al. 2014a - A molecular phylogenetic reappraisal of the Didymosphaeriaceae (= Montagnulaceae). Fungal Diversity 68, 69-104.

Ariyawansa HA, Kang JC, Alias SA, Chukeatirote E, Hyde KD. 2014b - Pyrenophora. Mycosphere, 5, 351-362.

Ariyawansa HA, Hawksworth DL, Hyde KD, Jones EBG et al. 2014c - Epitypification and neotypification: guidelines with appropriate and inappropriate examples. Fungal Diversity 69(1), 57-91.

Ariyawansa HA, Hyde KD, Jayasiri SC, Buyck B et al. 2015a - Fungal diversity notes 111-252taxonomic and phylogenetic contributions to fungal taxa. Fungal Diversity 75, 27-274.

Ariyawansa HA, Thambugala KM, Manamgoda DS, Jayawardena R et al. 2015b - Towards a natural classification and backbone tree for Pleosporaceae. Fungal Diversity 71, 85-139.

Arzanlou M, Groenewald JZ, Gams W, Braun U, Shin HD, Crous P. 2007 - Phylogenetic and morphotaxonomic revision of Ramichloridium and allied genera. Studies in Mycology 58, 57-93.

Ballance GM, Lamari L, Bernier CC. 1989 - Purification and characterization of a host-selective necrosis toxin from Pyrenophora tritici-repentis. Physiological and Molecular Plant Pathology 35(3), 203-213.

Bakhshi M, Arzanlou M, Babai-Ahari A, Groenewald JZ et al. 2015 - Application of the consolidated species concept to Cercospora spp. from Iran. Persoonia 34, 65-86. 
Berkeley MJ, Curtis MA. 1868 - Fungi Cubenses (Hymenomycetes) [cont.]. Journal of the Linnean Society Botany 10, 321-341 [nos 315-488].

Brooks SA, Anders MM, Yeater KM. 2009 - Effect of cultural management practices on the severity of false smut and kernel smut of rice. Plant Disease, 93, 1202-1208.

Cai L, Zhang K, McKenzie EH, Hyde KD. 2003 - Freshwater fungi from bamboo and wood submerged in the Liput River in the Philippines. Fungal Diversity 13, 1-12.

Cai L, Ji KF, Hyde KD. 2006 - Variation between freshwater and terrestrial fungal communities on decaying bamboo culms. Antonie van Leeuwenhoek 89, 293-301.

Chen Q, Jiang JR, Zhang GZ, Cai L, Crous PW. 2015 - Resolving the Phoma enigma. Studies in Mycology 82, 137-217.

Chomnunti P, Hongsanan S, Aguirre-Hudson B, Tian Q et al. 2014 - The sooty moulds. Fungal Diversity 66, 1-36.

Clay K. 1988 - Fungal endophytes of grasses: a defensive mutualism between plants and fungi. Ecology 69(1), 10-16.

Clements FE. 1909 - The genera of fungi. The HW Wilson Company.

Cooke MC. 1877 - New British fungi (cont.). Grevillea. 5(35), 118-122.

Cooke WB. 1983a - The 1979 Oklahoma Foray. Mycologia 75(4), 752-755.

Cooke WB 1983b - Coniothyriaceae. Review of Biology (Lisbon) 12,289.

Crous PW, Schoch CL, Hyde KD, Wood AR et al. 2009 - Phylogenetic lineages in the Capnodiales. Studies in Mycology 64, 17-47.

Crous PW, Wingfield MJ, Schumacher RK, Summerell BA et al. 2014 - Fungal planet description sheets: 281-319. Persoonia 33, 212-289.

Crous PW, Carris LM, Giraldo A, Groenewald JZ et al. 2015 - The genera of fungi-fixing the application of the type species of generic names-G 2: Allantophomopsis, Latorua, Macrodiplodiopsis, Macrohilum, Milospium, Protostegia, Pyricularia, Robillarda, Rotula, Septoriella, Torula, and Wojnowicia. IMA fungus 6, 163-198.

Cummins GB. 1971 - The rust fungi of cereals, grasses and bamboos. Springer Verlag, New York.

Dai D, Bhat DJ, Liu J, Chukeatirote E et al. 2012 - Bambusicola, a new genus from bamboo with asexual and sexual morphs. Cryptogamie, Mycologie 33, 363-379.

Dai DQ, Phookamsak R, Wijayawardene NN, Li WJ et al. 2017 - Bambusicolous fungi. Fungal Diversity 82, 1-105.

Dai DQ, Bahkali AH, Ariyawansa HA, Li WJ et al. 2016 - Neokalmusia didymospora sp. nov. (Didymosphaeriaceae) from bamboo. Sydowia 68, 17-25.

Damm U, O'Connell RJ, Groenewald JZ, Crous PW. 2014 - The Colletotrichum destructivum species complex-hemibiotrophic pathogens of forage and field crops. Studies in Mycology 79, 49-84.

de Gruyter JD, Aveskamp MM, Woudenberg JHC, Verkley GJM et al. 2009 - Molecular phylogeny of Phoma and allied anamorph genera: towards a reclassification of the Phoma complex. Mycological Research 113, 508-519.

Eriksson O. 1967 - On graminicolous pyrenomycetes from Fennoscandia I. Dictyosporous species (339-380). II. Phragmosporous and scolecosporous species (381-440). III. Amerosporous and didymosporous species (441-466). Arkiv før Botanik. 6(4-5), 339466.

de Gruyter, Woudenberg JHC, Aveskamp MM, Verkley GJM et al. 2010 - Systematic reappraisal of species in Phoma section Paraphoma, Pyrenochaeta and Pleurophoma. Mycologia 102, 1066-1081.

Faris JD, Anderson JA, Francl LJ, Jordahl JG. 1996 - Chromosomal location of a gene conditioning insensitivity in wheat to a necrosis-inducing culture filtrate from Pyrenophora tritici-repentis. Phytopathology 86, 459-463.

Fischer GW. 1937 - Observations on the comparative morphology and taxonomic relationships of certain grass smuts in Western North America. Mycologia 29, 408-425. 
García-Guzmán G, Burdon J. 1997 - Impact of the flower smut Ustilago cynodontis (Ustilaginaceae) on the performance of the clonal grass Cynodon dactylon (Gramineae). American Journal of Botany, 84, 1565-1565.

Gibson DJ. 2009 - Grasses and grassland ecology. Oxford University Press.

Gruzdevienė E, Mankevičienė A, Lugauskas A, Repečkienė J. 2006 - The effect of environmental conditions on the variation of fungi and mycotoxin contents in oil flax seed. Ekologija 3, 64-70.

Hall TA. 1999 - BioEdit: a user-friendly biological sequence alignment editor and analysis program for Windows 95/98/NT. In: Nucleic Acids Symposium Series, 95-98.

Hawksworth DL, Kirk PM, Sutton BC, Pegler DN. 1995 - Ainsworth \& Bisby's Dictionary of the Fungi (8 Edn). CAB International.

Hennings P. 1904 - Einige neue Pilze aus Japan. Hedwigia 43, 140-146.

Höhnel F von. 1909 - Fragmente zur Mykologie: IX. Mitteilung (Nr. 407 bis 467). Sitzungsberichte der Kaiserlichen Akademie der Wissenschaften Math.-naturw. Klasse Abt. I. 118, 1461-1552.

Hsieh WH. 1979 - The causal organism of sugarcane leaf blight. Mycologia 71, 892-898.

Hyde KD, Jones EBG, Liu JK, Ariyawansa H et al. 2013 - Families of Dothideomycetes. Fungal Diversity 63, 1-313.

Hyde KD. 1997 - The genus Roussoëlla, including two new species from palms in Cuyabeno, Ecuador. Mycological Research 101, 609-616.

Hyde KD, Fröhlich J, Taylor JE. 1998 - Fungi from palms. XXXVI. Reflections on unitunicate ascomycetes with apiospores. Sydowia 50, 21-80.

Hyde KD, Hongsanan S, Jeewon R, Bhat DJ et al. 2016 - Fungal diversity notes 367-491: taxonomic and phylogenetic contributions to fungal taxa. Fungal Diversity 80(1), 1-270

Index Fungorum 2017 - http://www.indexfungorum.org/Names/Names.asp. Retrieved on 2 January 2017

Jayasiri SC, Hyde KD, Ariyawansa HA, Bhat DJ et al. 2015a - The faces of fungi database: fungal names linked with morphology, phylogeny and human impacts. Fungal Diversity 74, 3-18.

Jayasiri SC, Wanasinghe DN, Ariyawansa HA, Jones EBG et al. 2015b - Two novel species of Vagicola (Phaeosphaeriaceae) from Italy. Mycosphere 6, 716-728.

Kellogg EA. 2001 - Evolutionary history of the grasses. Plant physiology 125, 1198-1205.

Kirk PM, Cannon PF, Minter DW, Stalpers JA. 2008 - Ainsworth \& Bisby's dictionary of the fungi, 10th edn. CABI, Wallingford.

Lamari L, Bernier CC. 1989 - Evaluation of wheat lines and cultivars to tan spot [Pyrenophora tritici-repentis] based on lesion type. Canadian Journal of Plant Pathology 11, 49-56.

Lamprecht SC, Crous PW, Groenewald JZ, Tewoldemedhin YT, Marasas WF. 2011 Diaporthaceae associated with root and crown rot of maize. IMA fungus 2, 13-24.

Latchs GCM, Christensen MJ. 1985 - Artificial infection of grasses with endophytes. Annals of Applied Biology 107, 17-24.

Leuchtmann A. 1984 - Über Phaeosphaeria Miyake und andere bitunicate Ascomyceten mit mehrfach querseptierten Ascosporen. Sydowia 37, 75-194.

Li WJ, Bhat DJ, Camporesi E, Tian Q et al. 2015 - New asexual morph taxa in Phaeosphaeriaceae. Mycosphere 6, 681-708.

Li GJ, Hyde KD, Zhao RN, Hongsanan S et al. 2016 - Fungal diversity notes 253-366: taxonomic and phylogenetic contributions to fungal taxa. Fungal Diversity 78, 1-237.

Liu JK, Phookamsak R, Dai DQ, Tanaka K et al. 2014 - Roussoellaceae, a new pleosporalean family to accommodate the genera Neoroussoella gen. nov., Roussoella and Roussoellopsis. Phytotaxa 181, 1-33.

Liu JK, Hyde KD, Jones EBG, Ariyawansa HA et al. 2015 - Fungal diversity notes 1-110: taxonomic and phylogenetic contributions to fungal species. Fungal Diversity 72, 1-197.

Manamgoda DS, Cai L, Bahkali AH, Chukeatirote E et al. 2011 - Cochliobolus: an overview and current status of species. Fungal Diversity 51, 3-42. 
Manamgoda DS, Cai L, McKenzie EH, Crous PW et al. 2012 - A phylogenetic and taxonomic reevaluation of the Bipolaris-Cochliobolus-Curvularia complex. Fungal Diversity 56, 131144.

Manamgoda DS, Rossman AY, Castlebury LA, Chukeatirote E, Hyde, KD. 2015 - A taxonomic and phylogenetic re-appraisal of the genus Curvularia (Pleosporaceae): human and plant pathogens. Phytotaxa 212, 175-198.

Manoharachary C, Kunwar IK. 2010 - Spegazzinia species from India. Taxonomy and Ecology of Indian fungi. IK Internat Pvt Ltd, New Delhi 13-18.

Miller MA, Pfeiffer W, Schwartz T. 2010 - Creating the CIPRES Science Gateway for inference of large phylogenetic trees. In Proceedings of the Gateway Computing Environments Workshop (GCE), 14 Nov. 2010, New Orleans, LA pp 1-8.

Müller E. 1977 - Zur Pilzflora der Aletschwaldreservats (Kt. Wallis, Schweiz). Beiträge zur Kryptogamenflora der Schweiz 15, 1-126

Nene YL, Sheila VK, Sharma SB. 1996 - A world list of chickpea and pigeonpea pathogens. Patancheru 502, 324.

Omacini M, Chaneton EJ, Ghersa CM, Otero P. 2004 - Do foliar endophytes affect grass litter decomposition? A microcosm approach using Lolium multiflorum. Oikos 104, 581-590.

Orton CR. 1944 - Graminicolous species of Phyllachora in North America. Mycologia, 36(1), 1853.

Parbery DG. 1967 - Studies on graminicolous species of Phyllachora Nke. in Fckl. V. A taxonomic monograph. Australian Journal of Botany 15(2), 271-375.

Pearce CA, Reddell P, Hyde KD. 2000 - A member of the Phyllachora shiraiana complex (Ascomycota) on Bambusa arnhemica: a new record for Australia. Australasian Plant Pathology 29(3), 205-210.

Phookamsak R, Liu JK, McKenzie EHC, Manamgoda DS et al. 2014a - Revision of Phaeosphaeriaceae. Fungal Diversity 68, 159-238.

Phookamsak R, Liu JK, Manamgoda DS, Chukeatirote et al. 2014b - The sexual state of Setophoma. Phytotaxa 176(1), 260-269.

Phukhamsakda C, Ariyawansa HA, Phillips AJ, Wanasinghe DN et al. 2016 - Additions to Sporormiaceae: Introducing two novel genera, Sparticola and Forliomyces, from Spartium. Cryptogamie Mycologie 37, 75-97.

Poon MOK, Hyde KD. 1998 - Biodiversity of intertidal estuarine fungi on Phragmites at Mai Po marshes, Hong Kong. Botanica Marina 41, 141-156.

Prasher IB, Verma RK. 2015 - Some new and interesting hyphomycetes from North-Western Himalayas, India. Nova Hedwigia 100, 269-277.

Purahong W, Hyde KD. 2011 - Effects of fungal endophytes on grass and non-grass litter decomposition rates. Fungal Diversity 47(1), 1-7.

Quaedvlieg W, Verkley GJM, Shin HD, Barreto RW et al. 2013 - Sizing up Septoria. Studies in Mycology 75, 307-390.

Saccardo PA. 1878 - Fungi Veneti novi vel critici vel mycologiae Venetae addendi. Series VII. Michelia 1(2), 133-221.

Saccardo PA. 1880 - Fungi Gallici lecti a cl. viris P. Brunaud, Abb. Letendre, A. Malbranche, J. Therry, vel editi in Mycotheca Gallica C. Roumeguèri. Series II. Michelia 2, 39-135.

Saccardo PA. 1886 - Sylloge Fungorum 4: i-v, 1-807. Italy, Padia; P.A. Saccardo.

Shoemaker RA, Babcock CE. 1989 - Phaeosphaeria. Canadian Journal of Botany 67, 1500-1599.

Shoemaker RA, Babcock CE. 1992 - Applanodictyosporous Pleosporales: Clathrospora, Comoclathris, Graphyllium, Macrospora, and Platysporoides. Canadian Journal of Botany 70, 1617-1658.

Sharp D, Simon BK. 2002 - AusGrass: Grasses of Australia. Australian Biological Resources Study, Canberra and Environmental Protection Agency, Queensland. 
Siegrist JA, McCulley RL, Bush LP, Phillips TD. 2010 - Alkaloids may not be responsible for endophyte associated reductions in tall fescue decomposition rates. Functional Ecology 24, 460-468.

Simmons EG. 1993 - Alternaria themes and variations (63-72). Mycotaxon 48, 91-107.

Smiley RW, Dernoeden PH, Clarke BB. 2005 - Compendium of turfgrass diseases (No. Edn 3). American Phytopathological Society.

Spegazzini C. 1909 - Ophiosphaerella. Anales del Museo Nacional de Historia Natural Buenos Aires 19(12), 401 [ser. 3, 12].

Stamatakis A 2006 - RAxML-VI-HPC: Maximum likelihood-based phylogenetic analyses with thousands of taxa and mixed models. Bioinformatics 22, 2688-2690.

Stamatakis A, Hoover P, Rougemont J. 2008 - A rapid bootstrap algorithm for the RAxML Web servers. Systematic Biology 57, 758-771.

Tamura K, Peterson D, Peterson N, Stecher G et al. 2011 - MEGA5: molecular evolutionary genetics analysis using maximum likelihood, evolutionary distance, and maximum parsimony methods. Molecular Biology and Evolution 28, 2731-2739.

Tanaka K, Hirayama K, Yonezawa H, Sato G et al. 2015 - Revision of the Massarineae (Pleosporales, Dothideomycetes). Studies in mycology 82, 75-136.

Thambugala KM, Daranagama DA, Camporesi E, Singtripop C et al. 2014a - Multi-locus phylogeny reveals the sexual state of Tiarosporella in Botryosphaeriaceae. Cryptogamie Mycologie 35, 359-367.

Thambugala KM, Ariyawansa H.A, Li YM, Boonmee S et al. 2014b - Dothideales. Fungal Diversity 68, 105-158.

Thambugala KM, Hyde KD, Tanaka K, Tian Q et al. 2015a - Towards a natural classification and backbone tree for Lophiostomataceae, Floricolaceae, and Amorosiaceae fam. nov. Fungal Divers 74, 199-266.

Thambugala KM, Chunfang Y, Camporesi E, Bahkali AH et al. 2015b - Pseudodidymosphaeria gen. nov. in Massarinaceae. Phytotaxa 231, 271-282.

Thambugala KM, Daranagama DA, Phillips AJ, Bulgakov TS et al. 2017 - Microfungi on Tamarix. Fungal Diversity 82, 239-306

Tode HJ. 1791 - Fungi Mecklenburgenses Selecti 2, 1-64.

Verkley GJM, Dukik K, Renfurm R, Göker M, Stielow JB. 2014 - Novel genera and species of coniothyrium-like fungi in Montagnulaceae (Ascomycota). Persoonia 32, 25-51.

Wanasinghe DN, Jones EBG, Camporesi E, Dissanayake AJ et al. 2016 - Taxonomy and phylogeny of Laburnicola gen. nov. and Paramassariosphaeria gen. nov. (Didymosphaeriaceae, Massarineae, Pleosporales). Fungal Biology 120, 1354-1373.

Watson L. 1990 - The grass family, Poaceae. Reproductive versatility in the grasses 1-31.

Wheeler DJ, Jacobs SW, Norton BE. 1990 - Grasses of New South Wales. University of New England.

Wijayawardene NN, Hyde KD, Wanasinghe DN, Papizadeh M et al. 2016 - Taxonomy and phylogeny of dematiaceous coelomycetes. Fungal Diversity 77, 1-316.

Wong MKM, Goh TK, Hyde KD. 2000 - Paraphaeosphaeria schoenoplecti sp. nov. from senescent culms of Schoenoplectus litoralis in Hong Kong. Fungal Diversity 4, 171-179.

Wong MK, Hyde KD. 2001 - Diversity of fungi on six species of Gramineae and one species of Cyperaceae in Hong Kong. Mycological Research 105, 1485-1491.

Woudenberg JHC, Groenewald JZ, Binder M, Crous PW. 2013 - Alternaria redefined. Studies in Mycology 75, 171-212.

Woudenberg JHC, Seidl MF, Groenewald JZ, de Vries M et al. 2015 - Alternaria section Alternaria: Species, formae speciales or pathotypes?. Studies in Mycology 82, 1-21.

Yang JW, Yeh YH, Kirschner R. 2016 - A new endophytic species of Neostagonospora (Pleosporales) from the coastal grass Spinifex littoreus in Taiwan. Botany 94, 593-598. 